\title{
Continental Scale Estimates of the Biotic Carbon Flux from Land Cover Change: 1850 to 1980
}

\author{
R. A. Houghton - J. L. Hackler
}

R. C. Daniels, editor
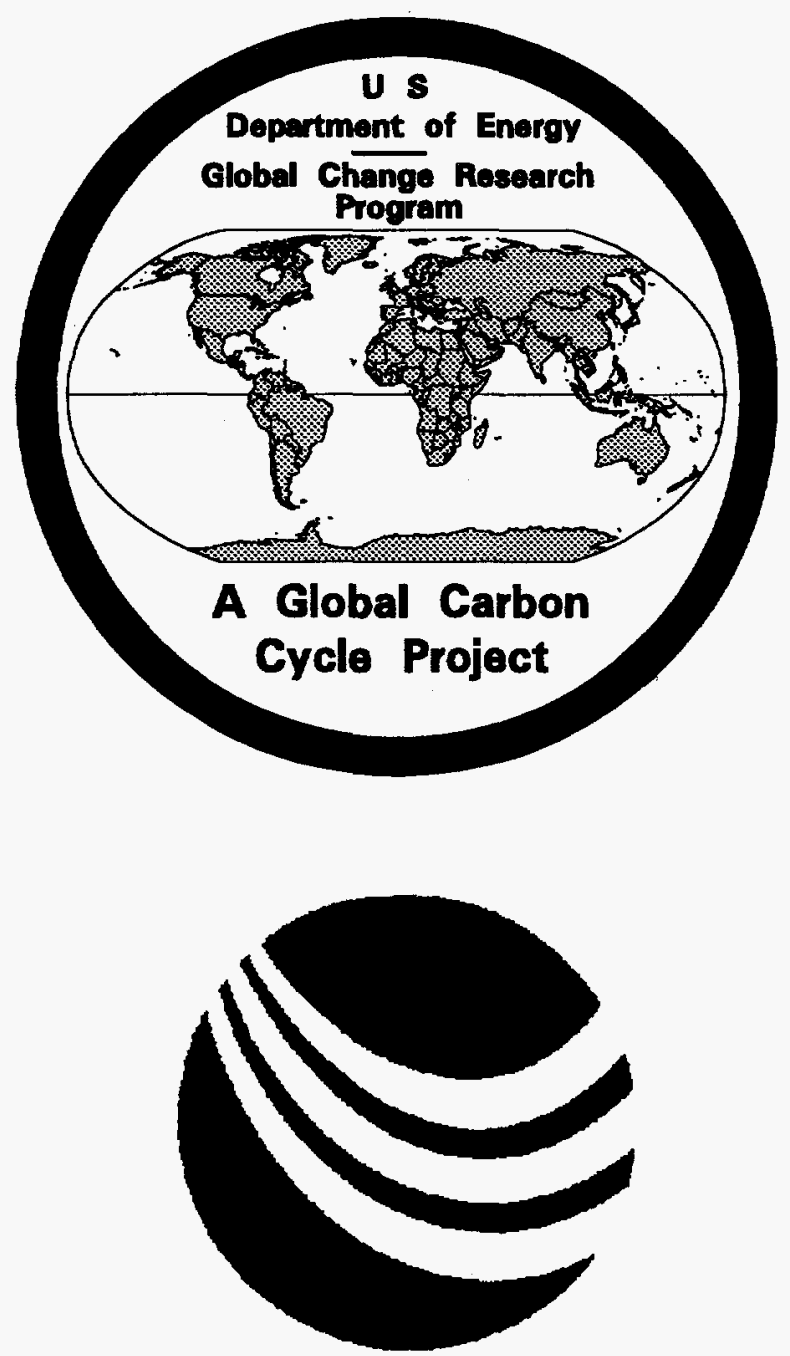

Carbon Dioxide Information Analysis Center

Oak Ridge National Laboratory

Environmental Sciences Division

Publication No. 4379 
This report has been reproduced directly from the best available copy.

Available to DOE and DOE contractors from the Office of Scientific and Technical Information, P.O. Box 62, Oak Ridge, TN 37831; prices available from (615) 576-8401, FTS 626-8401.

Available to the public from the National Technical Information Service, U.S. Department of Commerce, 5285 Port Royal Rd., Springfield, VA 22161.

This report was prepared as an account of work sponsored by an agency of the United States Government. Neither the United States Government nor any agency thereof, nor any of their employees, makes any warranty, express or implied, or assumes any legal liability or responsibility for the accuracy, completeness, or usefulness of any information, apparatus, product, or process disclosed, or represents that its use would not infringe privately owned rights. Reference herein to any specific commercial product, process, or service by trade name, trademark, manufacturer, or otherwise, does not necessarily constitute or imply its endorsement, recommendation, or favoring by the United States Government or any agency thereof. The views and opinions of authors expressed herein do not necessarily state or reflect those of the United States Government or any agency thereof. 


\section{DISCLAIMER}

Portions of this document may be illegible in electronic image products. Images are produced from the best available original document. 


\title{
CONTINENTAL SCALE ESTIMATES OF THE BIOTIC CARBON FLUX FROM LAND COVER CHANGE: 1850 TO 1980
}

\author{
Contributed by \\ Richard A. Houghton and Joseph L. Hackler \\ The Woods Hole Research Center \\ Woods Hole, Massachusetts \\ Edited by Richard C. Daniels ${ }^{1}$ \\ Carbon Dioxide Information Analysis Center \\ Environmental Sciences Division \\ Publication No. 4379 \\ Date Published: March 1995 \\ Prepared for the \\ Global Change Research Program \\ Environmental Sciences Division \\ Office of Health and Environmental Research \\ U.S. Department of Energy \\ Budget Activity Number KP 0502000 \\ Prepared by the \\ Carbon Dioxide Information Analysis Center \\ OAK RIDGE NATIONAL LABORATORY \\ Oak Ridge, Tennessee 37831-6335 \\ managed by \\ MARTIN MARIETTA ENERGY SYSTEMS, INC. \\ for the \\ U.S. DEPARTMENT OF ENERGY \\ under contract DE-AC05-84OR21400
}

${ }^{\top}$ Energy, Environment and Resources Center, The University of Tennessee, Knoxville, Tennessee.

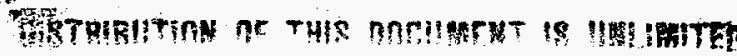


LIST OF FIGURES $\ldots \ldots \ldots \ldots \ldots \ldots \ldots \ldots \ldots \ldots \ldots \ldots \ldots \ldots \ldots$

LIST OF TABLES $\ldots \ldots \ldots \ldots \ldots \ldots \ldots \ldots \ldots \ldots \ldots \ldots \ldots$

ABSTRACT $\ldots \ldots \ldots \ldots \ldots \ldots \ldots \ldots \ldots \ldots \ldots \ldots \ldots \ldots \ldots \ldots \ldots$

PART 1: INFORMATION ABOUT THE DATA PACKAGE $\ldots \ldots \ldots \ldots \ldots \ldots \ldots$

1. NAME OF THE NUMERIC DATA PACKAGE $\ldots \ldots \ldots \ldots \ldots \ldots \ldots \ldots$

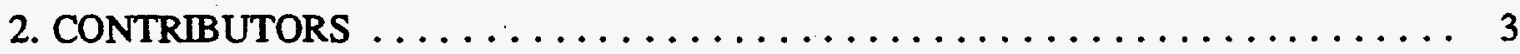

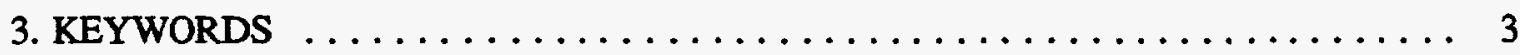

4. BACKGROUND INFORMATION $\ldots \ldots \ldots \ldots \ldots \ldots \ldots \ldots \ldots \ldots \ldots$

5. APPLICATIONS FOR THE DATA $\ldots \ldots \ldots \ldots \ldots \ldots \ldots \ldots \ldots \ldots \ldots$

6. COMPILATION OF LAND COVER CHANGE RATES $\ldots \ldots \ldots \ldots \ldots \ldots \ldots$

7. MODELING OF CARBON FLUX FROM LAND COVER CHANGE . . . . . . . 11

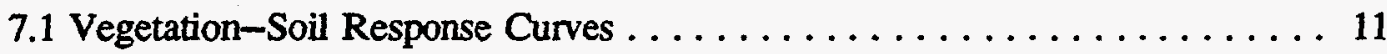

7.2 The Carbon Flux Model . . . . . . . . . . . . . . . . . . . 14

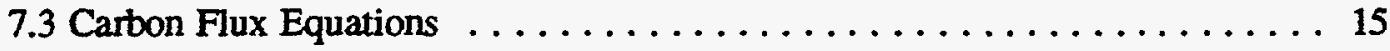

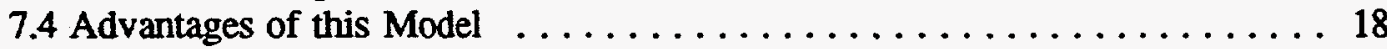

8. LIMTTATIONS AND RESTRICTIONS OF THE DATA $\ldots \ldots \ldots \ldots \ldots \ldots \ldots$

9. DATA CHECKS PERFORMED BY CDIAC $\ldots \ldots \ldots \ldots \ldots \ldots \ldots \ldots \ldots$

10. HOW TO OBTAIN THESE DATA AND ITS DOCUMENTATION $\ldots \ldots \ldots \ldots \ldots 21$

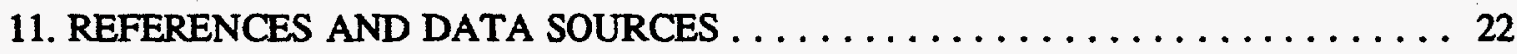

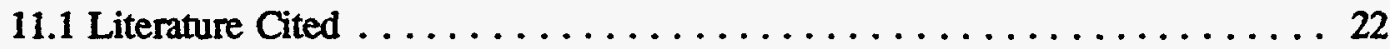

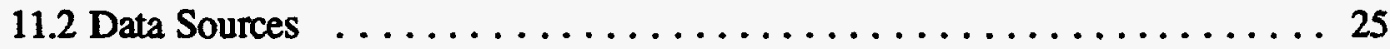

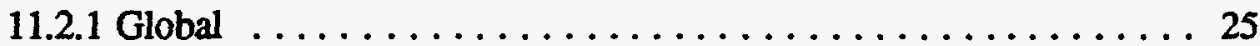

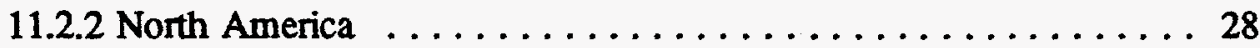

11.2.3 South and Central America . . . . . . . . . . . . . 29

11.2.4 Europe ........................... 33

11.2.5 North Africa and the Middle East $\ldots \ldots \ldots \ldots \ldots \ldots \ldots$

11.2.6 Tropical Africa . . . . . . . . . . . . . . . 34

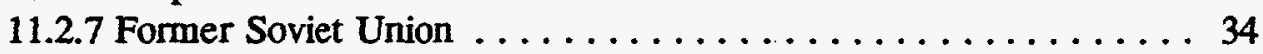

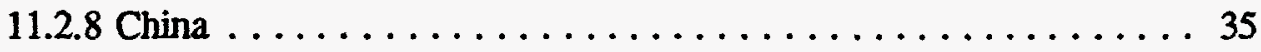

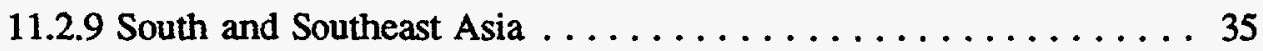

11.2.10 Pacific Developed Region . . . . . . . . . . . . 37 
PART 2: INFORMATION ABOUT THE COMPUTERIZED DATA FILES . . . . . . . 39

12. CONTENTS OF THE COMPUTERIZED DATA FILES $\ldots \ldots \ldots \ldots \ldots \ldots \ldots$

13. DESCRIPTIVE FILE ON THE MAGNETIC MEDIA $\ldots \ldots \ldots \ldots \ldots \ldots \ldots$

14. LISTING OF THE FORTRAN AND SAS ${ }^{\text {TM }}$ DATA RETRIEVAL

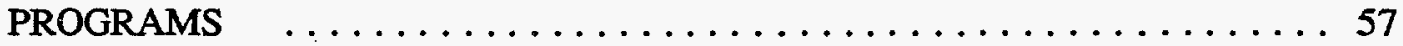

15. PARTIAL LISTING OF THE FLAT ASCII DATA FILES . . . . . . . . . . . 59

16. VERIFICATION OF DATA TRANSPORT: FLAT ASCII DATA FILES $\ldots \ldots \ldots$. . . 60

17. VERIFICATION OF DATA TRANSPORT: LOTUS $1-2-3^{\mathrm{TM}}$ DATA FILES $\ldots \ldots \ldots 62$

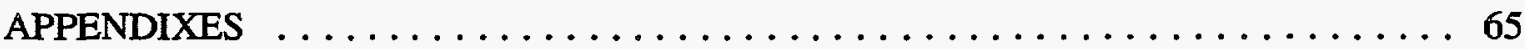

APPENDIX A: DEFINITION OF ECOSYSTEM NAMES

USED IN THIS DATABASE $\ldots \ldots \ldots \ldots \ldots \ldots \ldots \ldots \ldots \ldots \ldots$ A 1

APPENDIX B: VEGETATION-SOIL RESPONSE CURVE

PRINTOUTS FOR THE NINE REGIONS $\ldots \ldots \ldots \ldots \ldots \ldots \ldots \ldots \ldots \ldots$. . . . . .

APPENDIX C: PRINTOUT OF THE CARBON FLUX FOR

ALL NINE REGIONS AND THE WORLD $\ldots \ldots \ldots \ldots \ldots \ldots \ldots \ldots \ldots$.1

APPENDIX D: REPRINT OF PERTINENT LITERATURE $\ldots \ldots \ldots \ldots \ldots \ldots \ldots$ D-1

Changes in the carbon content of terrestrial biota and soils

between 1860 and 1980: a net release of $\mathrm{CO}_{2}$ to the atmosphere

By R. A. Houghton, J. E. Hobbie, J. M. Melillo, B. Moore,

B. J. Peterson, G. R. Shaver, and G. M. Woodwell. $1983 \ldots \ldots \ldots \ldots \ldots \ldots$. . . . . 


\section{LIST OF FIGURES}

1. Map of the nine regions covered in this database $\ldots \ldots \ldots \ldots \ldots \ldots$

2. Comparison of the stepwise function and linear function using the tropical moist forest-to-cropland conversion curve in the Pacific Developed Region $\ldots \ldots \ldots \ldots \ldots \ldots \ldots \ldots$

3. Changes in the carbon content of living vegetation and soils: clearing, abandonment, and regrowth $\ldots \ldots \ldots \ldots \ldots \ldots \ldots \ldots \ldots$

4. Schematic representation of the transfer of carbon and biomass that occurs when forested lands are cleared

5. Diagram showing the file combinations used in calculating land cover change and carbon flux in each region (NAM=North America, EURO=Europe, FSU=Former Soviet Union, PCDV=Pacific Developed, CHIN=China, SCAM=South and Central America, NAFM=North Africa-Middle East, TAF=Tropical Africa, and ASIA=South and Southeast Asia) 


\section{LIST OF TABLES}

1. Countries comprising the nine regions in the terrestrial carbon model $\ldots \ldots \ldots 6$

2. Natural ecosystems within each of the nine regions $\ldots \ldots \ldots \ldots \ldots \ldots$

3. Vegetation-Soil response curve with data showing changes in the amount of carbon sequestered in live vegetation and soils caused by the clearing of natural ecosystems in Tropical Africa for cropland or pasture ... 12

4. List and description of the digital files $\ldots \ldots \ldots \ldots \ldots \ldots \ldots \ldots \ldots$

5. Variable formats for AREAS.ASC $\ldots \ldots \ldots \ldots \ldots \ldots \ldots \ldots \ldots \ldots$

6. Variable formats for NETFLUX.ASC ................ 49

7. Statistical characteristics of the numeric variables in AREAS.ASC $\ldots \ldots \ldots 60$

8. Statistical characteristics of the numeric variables in NETFLUX.ASC $\ldots \ldots \ldots 6$

9. File characteristics of the 20 Lotus $1-2-3^{\mathrm{TM}}$ spreadsheet files $\ldots \ldots \ldots \ldots \ldots$ 
Houghton, R. A. and J. L. Hackler. 1995. Continental Scale Estimates of the Biotic Carbon Flux from Land Cover Change: 1850 to 1980. ORNL/CDIAC-79, NDP-050, Oak Ridge National Laboratory, Oak Ridge, Tennessee. 144 pp.

This document describes a Numeric Data Package (NDP) that contains annual carbon flux estimates from land cover change for nine regions of the world (i.e., North America, Europe, the Former Soviet Union, Pacific Developed Region, China, South and Central America, North Africa-Middle East, Tropical Africa, and South and Southeast Asia). Annual rates of land cover change and vegetation-soil response curves for each region and ecosystem are included in the database. The vegetation-soil curves are used in a bookkeeping carbon model to estimate the carbon flux with the atmosphere from the clearing or degradation of vegetation, cultivation of soils, decay of dead vegetation, and the recovery of abandoned lands. The model calculates the net flux of carbon in each region based on land cover change rates and vegetation-soil response curves for the period 1850 to 1980 (a few regions have land cover records beginning in 1700 and carbon flux estimates ending in 1990). These data were collected and modeled in an attempt to reduce the uncertainty associated with the magnitude and time course of the flux of carbon from terrestrial vegetation to the atmosphere.

Analysis of the land cover data found that about $58 \times 10^{6}$ ha of land were converted to agricultural use in 1980 alone. About $40 \%$ of this total involved lands previously cleared or degraded by shifting cultivators. These land cover changes resulted in a net flux to the atmosphere of $1.4 \times 10^{9} \mathrm{Mg}$ of Carbon. This clearing, and the degradation of other ecosystems, is a result of increased demand for agricultural and wood products by the world's growing population. These demands have resulted in a significant decline in the amount of carbon sequestered per hectare of forest. For example, in South and Southeast Asia the mean carbon content of forestland has decreased from $137 \mathrm{Mg} \mathrm{C/ha}$ in 1880 to $109 \mathrm{Mg}$ C/ha in 1980 , a $20 \%$ decrease in 100 years.

The data is this NDP were developed in three phases. The first phase was the collection of land cover change data from international and national data sources and the conversion of these data into annual rates of clearing, logging, or abandonment for each major ecosystem in a region. Secondly, regional- and ecosystem-specific vegetation-soil response curves were developed for each region. In the final phase, the land cover change rates and response curves were entered into a sequential bookkeeping model and the annual flux of carbon from land cover change was calculated. The resulting NDP contains: annual deforestation/afforestation rates, vegetation-soil response curves for each natural ecosystem in each region, and the net annual flux of carbon to or from the atmosphere for each region.

These data are available from the Carbon Dioxide Information Analysis Center (CDIAC). The NDP consists of this document and a set of 20 Lotus $1-2-3^{\mathrm{TM}}$ files, 3 flat ASCII data files, and 2 FORTRAN and 2 SAS ${ }^{\text {TM }}$ data retrieval programs. This document contains information on the methods and model used in obtaining each variable; descriptions of file contents and formats; and discuses the sources, restrictions, and limitations of the data. These data are available free of charge from CDIAC on a variety of media as well as through the Internet.

Lotus $1-2-3^{T M}$ is a registered trademark of Lotus Development Corporation, Cambridge, Massachusetts 02142.

SAS $^{\mathrm{TM}}$ is a registered trademark of the SAS Institute, Inc., Cary, North Carolina 27511. 
PART 1: INFORMATION ABOUT THE DATA PACKAGE 



\section{NAME OF THE NUMERIC DATA PACKAGE}

\section{CONTINENTAL SCALE ESTIMATES OF THE BIOTIC CARBON \\ FLUX FROM LAND COVER CHANGE: \\ 1850 TO 1980}

\section{CONTRIBUTORS}

Richard A. Houghton

The Woods Hole Research Center

P.O. Box 296

Woods Hole, Massachusetts 02543

U.S.A.
Joseph L. Hackler

The Woods Hole Research Center

P.O. Box 296

Woods Hole, Massachusetts 02543

U.S.A.

\section{KEYWORDS}

Afforestation, biomass, carbon flux, decay pool, deforestation, terrestrial ecosystems, slash, soil carbon, China, Europe, Former Soviet Union, North Africa-Middle East, North America, Pacific Developed Region, South and Central America, South and Southeast Asia, Tropical Africa

\section{BACKGROUND INFORMATION}

Measurements taken since 1958 at Mauna Loa Observatory, Hawaii, have shown a continued increase in the atmospheric concentration of $\mathrm{CO}_{2}$ (Keeling and Whorf 1994). This increase has been related to the release of carbon into the atmosphere from the burning of fossil fuels. However, estimates made in 1980 found that the net release of $\mathrm{CO}_{2}$ from land cover change in the tropics was $0.4 \times 10^{9}$ to $2.5 \times 10^{9} \mathrm{Mg}$ of Carbon, 10 to $50 \%$ of the carbon released from the burning of fossil fuels in that year (Houghton et al. 1987, Houghton et al. 1991b, Marland and Rotty 1984). Recognition by the climate change research community that changes in the type, concentration, and health of terrestrial biota had a significant influence on the abundance of $\mathrm{CO}_{2}$ in the atmosphere resulted in the U.S. Department of Energy's (DOE's) component of the U.S. Global Change Research Program (GCRP) funding several research projects to examine the terrestrial sources and sinks of atmospheric $\mathrm{CO}_{2}$.

The mission of DOS's portion of the GCRP is to predict the future atmospheric concentration of $\mathrm{CO}_{2}$ and other energy-related greenhouse gases and the impacts that these could have on climate; to understand and predict the impact of emissions and climate change on biota; and to understand the economic costs or benefits of climate change and the costs that would be associated with policies aimed at mitigating the impacts of global warming (Patrinos 1993). Thus, one of the primary missions of DOE's GCRP is to measure and model the physical, chemical, and biological sources and sinks of $\mathrm{CO}_{2}$. This information is needed to determine the cycling rates and direction of carbon transport through the global carbon cycle, and to allow for the prediction of atmospheric concentrations of $\mathrm{CO}_{2}$ in relation to its release from the burning of fossil fuels and deforestation, and its uptake from afforestation and deep ocean transport.

To this end, the Global Carbon Cycle component of DOE's GCRP provided approximately $\$ 670$ thousand from 1983 to 1994 for the construction of a global database of land cover change and a bookkeeping-type model that would track the flux of carbon in the atmosphere caused by the degradation of forests and changes in land cover (e.g., land clearing, shifting cultivation, 
afforestation).

This database contains annual estimates of the rate of land cover change for up to 18 different ecosystems in nine regions of the world (i.e., North America, Europe, the Former Soviet Union, Pacific Developed Region, China, South and Central America, North Africa-Middle East, Tropical Africa, and South and Southeast Asia) as well as regional and ecosystem specific soil and vegetation response curves. A bookkeeping model was utilized to calculate the net flux of carbon in each region based on the land cover and response curve data. These carbon flux and land cover data have been estimated for the period 1850 to 1980 for all nine regions, with some regions having land cover records beginning in 1700 and carbon flux estimates ending in 1990. Results and conclusions derived from the model may be found in Houghton et al. $(1983,1985,1987$, 1991a, 1991b), Melillo et al. (1988), Houghton (1991a, 1991b, 1993), and Houghton and Hackler (1994). (A reprint of Houghton et al. 1983 is contained in Appendix C.)

Funding for this project was secured from FY 1983 through FY 1993 from the following agencies: the National Science Foundation (DEB-79-23329, BSR-8110477, BSR-8704749); the National Aeronautics and Space Administration (NAGW 970); the DOE Office of Health and Environmental Research (DE-FG02-90ER61079); and the Global Carbon Cycle component of DOE's GCRP (a fully integrated part of the U.S. Global Change Research Program), under subcontract 19X-SB830C from Oak Ridge National Laboratory, Oak Ridge, Tennessee, managed by Martin Marietta Energy Systems, Inc., for DOE under subcontract DE-AC05-840R21400.

\section{APPLICATIONS FOR THE DATA}

This database provides a continuous history of land cover change and carbon flux for nine regions of the world from 1850 through 1980, with some regions having land cover records beginning in 1700 and carbon flux data ending in 1990, as well as a set of regional and ecosystem specific vegetation-soil response curves. The land cover and response curve data, along with the carbon flux data derived from the model, may be utilized by climate modelers as inputs to general circulation models, by historians in regional and global scale studies of land cover change, or by any researcher interested in the interrelationships between anthropogenic activities and land cover change, land degradation, or atmospheric carbon concentrations.

\section{COMPILATION OF LAND COVER CHANGE RATES}

Historical land cover data were collected at the global, regional, and country level (e.g., Zon and Sparnawk 1923, Richards and Flint 1994, and Gifford 1992) and used to derive rates of land cover change for natural ecosystems in the nine regions shown in Fig. 1. These regions cover a majority of the vegetated land on Earth, with only small undeveloped islands and large unvegetated regions being excluded from the database (i.e., Antarctica and Greenland). Table 1 provides a list of the countries that occur within each of the nine regions. 


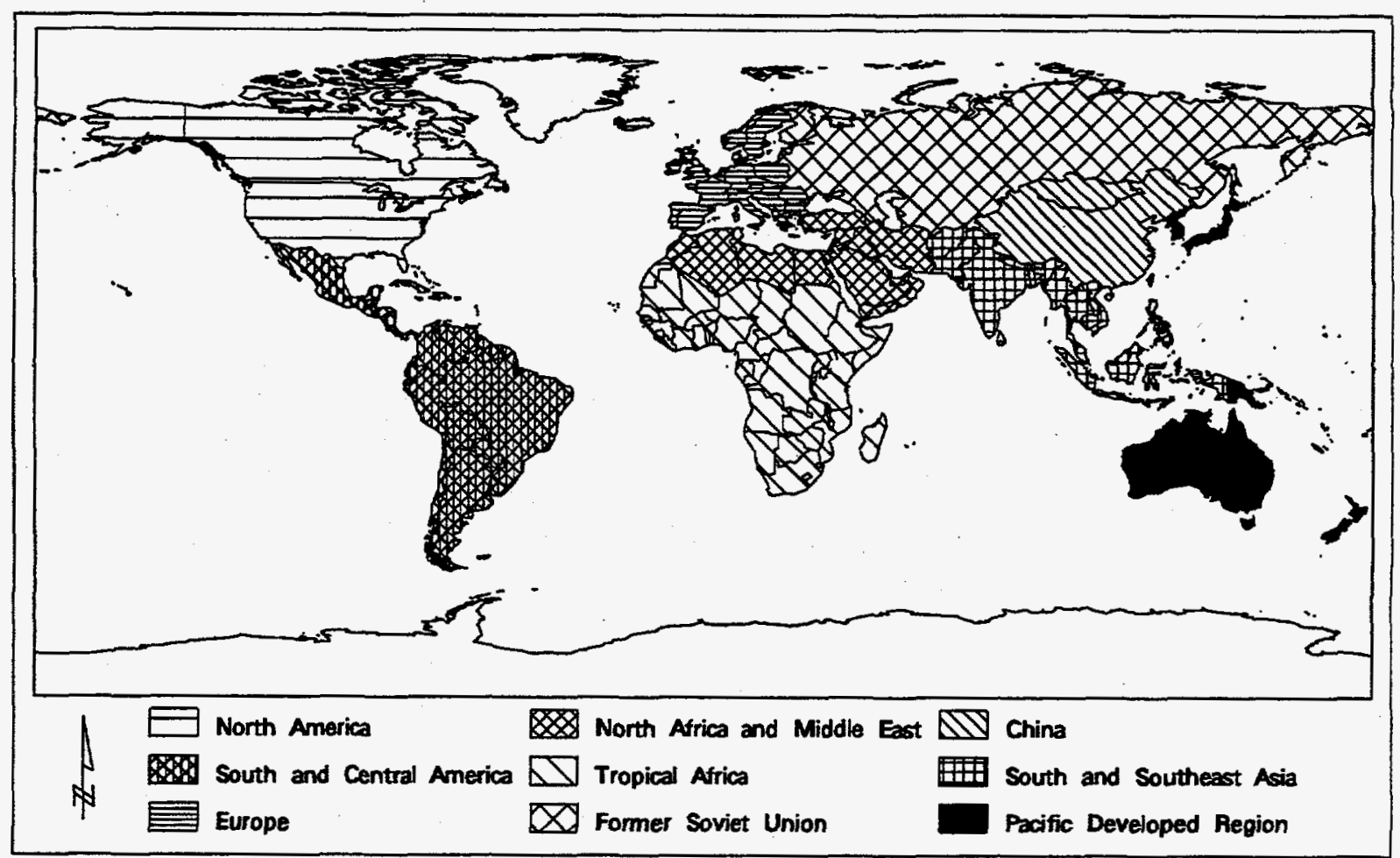

Figure 1. Map of the nine regions covered in this database.

Geographic location determines the ecosystems contained within a region. Thus, data were collected on and divided among the several different natural ecosystems occurring in each region. Availability of information on the type and extent of the ecosystems within each region determined the number of ecosystems utilized. Table 2 lists the natural ecosystems for which data were collected within each region. A listing of the primary data sources used during the compilation of this database are shown in Section 11.2. Due to the large number of secondary sources utilized, they have not been cited in this document. A majority of these secondary sources are cited in Hall et al. (1988), Bibliography on Tropical Rain Forests and the Global Carbon Cycle: An Introduction to the Literature. 
Table 1. Countries comprising the nine regions in the terrestrial carbon model

\begin{tabular}{|c|c|c|c|}
\hline \multicolumn{2}{|c|}{ North America } & \multicolumn{2}{|c|}{ North Africa-Middle East } \\
\hline Canada & United States & Afghanistan & Libya \\
\hline & & Algeria & Morocco \\
\hline \multicolumn{2}{|c|}{ South and Central America } & Bahrain & Oman \\
\hline Argentina & Guyana & Cyprus & Qatar \\
\hline Bahamas & Haiti & Egypt & Saudi Arabia \\
\hline Belize & Honduras & Iran & Syria \\
\hline Bolivia & Jamaica & Iraq & Tunisia \\
\hline Brazil & Martinique & Israel & Turkey \\
\hline Chile & Mexico & Jordan & United Arab Emirates \\
\hline Colombia & Nicaragua & Kuwait & Yemen \\
\hline Costa Rica & Panama & Lebanon & Yemen, Democratic \\
\hline Cuba & Paraguay & & \\
\hline Dominican Rep. & Pera & \multicolumn{2}{|c|}{ Tropical Africa } \\
\hline Ecuador & Puerto Rico & Angola & Mauritania \\
\hline El Salvador & Surinam & Benin & Mauritius \\
\hline Falkland Islands & Trinidad \& Tobago & Botswana & Mozambique \\
\hline French Guiana & Uruguay & Burundi & Nambia \\
\hline Guadeloupe & Venezuela & Cabinda & Niger \\
\hline Guatemala & & Cameroon & Nigeria \\
\hline \multirow{2}{*}{\multicolumn{2}{|c|}{ Europe }} & Central African Rep. & Rep. of Congo \\
\hline & & Chad & Réunion \\
\hline Albania & Ireland & Djibouti & Río Muni \\
\hline Andorra & Italy & Equatorial Guinea & Rwanda \\
\hline Austria & Liechtenstein & Ethiopia & Senegal \\
\hline Belgium & Luxembourg & Gabon & Sierra Leone \\
\hline Bulgaria & Malta & Gambia & Somalia \\
\hline Czechoslovakia & Monaco & Ghana & South Africa \\
\hline Denmark & Netherlands & Guinea & Sudan \\
\hline Finland & Norway & Guinea-Bissau & Swaziland \\
\hline France & Poland & Ivory Coast & Tanzania \\
\hline Germany & Portugal & Kenya & Togo \\
\hline Great Britain & Rumania & Lesotho & Uganda \\
\hline Greece & San Marino & Liberia & Upper Volta \\
\hline Hungary & Spain & Madagascar & Westem Sahara \\
\hline \multirow[t]{3}{*}{ Iceland } & Switzerland & Mali & Zaire \\
\hline & Yugoslavia & Malawi & Zambia \\
\hline & & & Zimbabwe \\
\hline
\end{tabular}


Table 1. (continued)

\begin{tabular}{|c|c|c|c|}
\hline \multicolumn{2}{|c|}{ Former Soviet Union } & \multicolumn{2}{|c|}{ South and Southeast Asia } \\
\hline Armenia & Lithuania & Bangladesh & Laos \\
\hline Azerbaijan & Moldavia & Bhutan & Malaysia \\
\hline Byelorussia & Russia & Brunei & Nepal \\
\hline Estonia & Tajik & Burma & Pakistan \\
\hline Georgia & Turkmen & Cambodia & Philippines \\
\hline Kazakh & Ukraine & India & Sri Lanka \\
\hline Kirghiz & Uzbek & Indonesia & Thailand \\
\hline Latvia & & & Vietnam \\
\hline \multicolumn{4}{|c|}{ China } \\
\hline \multirow{5}{*}{$\begin{array}{l}\text { Peoples Rep. } \\
\text { of China }\end{array}$} & Mongolia & \multicolumn{2}{|c|}{ Pacific Developed Region } \\
\hline & & Australia & Oceania \\
\hline & & Japan & Papua New Guinea \\
\hline & & New Zealand & South Korea \\
\hline & & North Korea & Taiwan \\
\hline
\end{tabular}

Table 2. Natural ecosystems within each of the nine regions

North America

Temperate evergreen forest

Temperate grassland

Boreal forest

South and Central America

Tropical equatorial forest

Tropical woodland

Temperate broadleaf forest

Desert scrub

\section{Europe}

Temperate evergreen forest

Temperate grassland
Temperate deciduous forest

Temperate woodland and shrubland

Tropical seasonal forest

Warm coniferous forest

Grassland

Temperate deciduous forest

Boreal forest 
Table 2.

(continued)

North Africa-Middle East

Temperate evergreen forest

Tropical moist forest

Desert scrub

Tropical Africa

Closed forest

(includes Bamboo forests)

Tropical grassland

Tropical woodland and shrubland

Open forest

Former Soviet Union

Temperate deciduous forest

Boreal forest

Temperate grassland

China

Temperate evergreen forest

Temperate deciduous forest

Temperate grassland

Tropical moist forest

South and Southeast Asia

Degraded:

Tropical moist forest

Tropical seasonal forest

Undisturbed:

Tropical moist forest

Tropical seasonal forest

Tropical open forest

Tropical open forest

Tropical grassland

Pacific Developed Region

Temperate evergreen forest

Tropical moist forest

Tropical woodland and shrubland

Temperate deciduous forest

Tropical grassland

Desert scrub

(Note: See Appendix A for regional ecosystem definitions.)

The ecosystems in each region (Table 2) were obtained by distributing the world vegetation types of Whittaker and Likens (1973) on Küchler's map of natural vegetation (Espenshade 1986). The area of each ecosystem within each region was then proportionally reduced by the land in agriculture in 1700 . Due to the lack of data prior to the 1800's, the total area of each ecosystem in each region for 1700 was extrapolated based on the regional ratio between population and land in agriculture (McEvedy and Jones 1978). Estimates of the amount of land in each ecosystem type, within each region, were then used as the seeds, or initial values, for the analysis. The rates of land cover change derived for the years following 1700 may be applied to this seed value to obtain the "actual" land area in each ecosystem.

Because the model calculating the flux of carbon does not include ecosystems in an 
undisturbed state (i.e., it is assumed that they have no net changes in their carbon content), the actual area in a given ecosystem is not relevant to the carbon model. Errors in the initial allocation of land to each ecosystems would affect the model only if the rates of land clearing exceeded the available land.

Data on the area in cropland for 1700 to 1980 were compiled by country from historical documents. In most cases, records are incomplete for the earlier years. In such cases it was necessary to extrapolate from a few countries to an entire region based on regional ratios between population and land in agriculture. For the years prior to 1950 in South and Central America, for example, Argentina, Brazil, and Mexico have the most complete historical land use records. These three countries currently contain over $75 \%$ of the region's cropland (Food and Agriculture Organization 1985). Assuming that this pattern was similar in the past, the total area cleared for cropland prior to 1950 may be approximated for the South and Central America region. This was done by constructing a annual ratio between the amount of cropland and population in Argentina, Brazil, and Mexico in relation to the regional population (Houghton et al. 1991a). For years after 1950 , cropland areas were generally obtained from individual country handbooks and the annual production yearbooks of the Food and Agriculture Organization (FAO).

The annual record of land cover change (i.e., rates of change) within each ecosystem were developed from noncontinuous data. The beginning rate of change for 1700-1701 was calculated from population, as discussed in the preceding paragraphs. Estimates of the rates of land cover change were made using data for individual years, or groups of years, with data. The rates for intervening years were then estimated using a stepwise or a linear function, depending on the region and ecosystem in question. Thus, the actual number of data points used to calculate the rates of change may be quite small before 1946 (the FAO began publication of their annual Production Yearbook in 1946). For example, in the Pacific Developed Region the annual conversion of the tropical moist forest ecosystem to cropland contains only four rates of change during the entire period of record (1700-1980). The first rate covers 1700-1869 and is population based; the second rate covers 1870-1949 and is based on Zon and Sparhawk (1923) and the first two FAO Production Yearbooks; the third (1950-1969) and fourth (1970-1980) rates were derived almost exclusively from FAO publications (e.g., FAO 1963).

In the Pacific Developed Region a stepwise function was used for the conversion of tropical moist forest to cropland. This means that a constant rate of change was used for each of the four periods, with the rate increasing in a stepwise fashion in 1870,1950, and 1970. If a linear function had been used in the preceding case, as is the situation for the logging of tropical moist forest, a "zero" rate would have been calculated for 1700. A linear equation would have been developed that viewed the zero and first rate as points on a line, and the first rate would be reached by the end of the first period. This process would be repeated for the first and second rates, second and third rates, and third and fourth rates. Figure 2 provides a graphic comparison of these two methods, based on the conversion curve for tropical moist forest to cropland. 


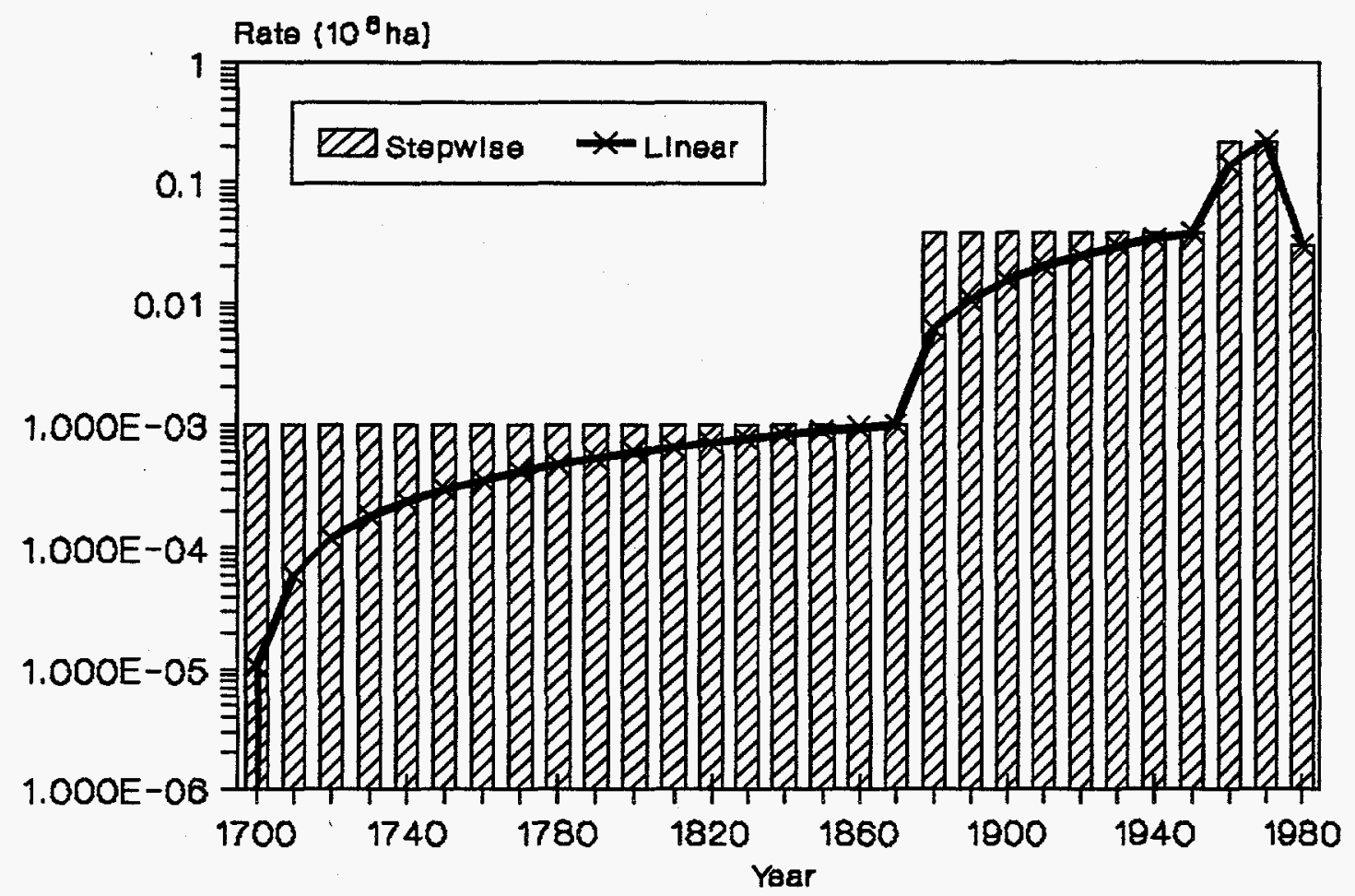

Figure 2. Comparison of the stepwise function and linear function using the tropical moist forest-to-cropland conversion curve in the Pacific Developed Region.

Land cover conversion curves similar to the one shown in Fig. 2 were developed for each ecosystem within each region. Each ecosystem may have up to seven conversion curves: (1) clearing for cropland, (2) clearing for pasture, (3) industrial logging, (4) nonindustrial logging, (5) shifting cultivation, (6) degradation, and (7) afforestation. However, in most cases only two or three conversion curves are needed for a given ecosystem within a region. 


\section{MODELING OF CARBON FLUX FROM LAND COVER CHANGE}

A reduction in the size of a given ecosystem, and changes in the total biomass within disturbed or cleared areas are readily observable. For example, the clearing of tropical moist forest for cropland will reduce the amount of biomass contained within vegetation. Not so obvious, though well documented (e.g., Schlesinger 1986), is the decline in soil carbon that follows clearing. Like the biomass of live vegetation, the carbon content of soils may recover to their predisturbance levels if the area is abandoned and allowed to recover. Thus, when modeling the flux of carbon within the atmosphere, information must be collected on land cover change (provided by the land cover change rates), the carbon content of vegetation and soils in each ecosystem, and recovery times associated with the regrowth of vegetation after abandonment.

\subsection{Vegetation-Soil Response Curves}

Each ecosystem, in each region, has a vegetation-soil response curve that contains information on the mean regional carbon content (per hectare) for undisturbed vegetation and soils, as well as information on the expected change in biomass that will occur due to disturbance. These values were first computed as dry matter and multiplied by 0.45 to obtain the carbon values shown in the response curves. The estimates of organic soil carbon used in this study were made for the top $1 \mathrm{~m}$ of soil by Schlesinger (1984), Palm et al. (1986), and Zinke et al. (1986). Estimates for vegetation were made based on Whittaker and Likens (1973), Olson et al. (1983), Lanly (1982), and Houghton et al. (1983). The data contained in these response curves include information on the minimum carbon content reached after clearing, time (in years) to reach this minimum, carbon in live vegetation (e.g., crops) left on site, time for carbon levels to recover after abandonment, time for recovered area to reach initial carbon levels, and the fraction of cleared vegetation assigned to decay pools (the carbon in harvested vegetation decays at different rates based on the use to which the vegetation is put).

In this model, five decay pools are used. The first contains slash and dead vegetation left on-site at the time of clearing. Biomass in this pool is released to the atmosphere based on an ecosystem and region specific on-site decay rate. The second is the 1-year decay pool. Biomass assigned to this pool is assumed to be bumed and released to the atmosphere in the year following clearing. The third, fourth, and fifth pools are the 10-year, 100-year, and 1000-year decay pools. The biomass assigned to these pools are released to the atmosphere using $0.1,0.01$, and 0.001 decay constants, respectively.

Response curve data contained in this database are for 1 ha of land. One of the response curve spreadsheets used for the clearing of forestland for crops and pasture in Tropical Africa is shown the Table 3. This table provides an example of the information contained in each response curve spreadsheet. Printouts of the response curves for all ecosystems and regions are contained in Appendix $B$. 
Table 3. Vegetation-Soil Response curve data showing changes in the amount of carbon sequestered in live vegetation and soils caused by the clearing of natural ecosystems in Tropical Africa for cropland or pasture

\begin{tabular}{|c|c|c|}
\hline & \multicolumn{2}{|c|}{ Natural ecosystems } \\
\hline & Closed forest & Open forest \\
\hline Carbon in vegetation of undisturbed ecosystem & 136 & 30 \\
\hline Carbon in vegetation of "recovered" ecosystem & 136 & 30 \\
\hline Carbon in crops & 15 & 15 \\
\hline Time for abandoned system to "recover" & 29 & 29 \\
\hline $\begin{array}{l}\text { Time for vegetation to recover to primary state } \\
\text { from "recovered" state }\end{array}$ & 1 & 1 \\
\hline Carbon in soils of undisturbed ecosystems & 100 & 50 \\
\hline Carbon in soils of "recovered" ecosystems & 100 & 50 \\
\hline $\begin{array}{l}\text { Carbon content of soil after initial rapid change } \\
\text { following clearing }\end{array}$ & 80 & 40 \\
\hline $\begin{array}{l}\text { Minimum carbon content of soil in cultivated } \\
\text { system }\end{array}$ & 75 & 37 \\
\hline Time to initial rapid change & 1 & 1 \\
\hline Time to soil minimum & 5 & 5 \\
\hline Time for soil to reach "recovered" state & 29 & 29 \\
\hline $\begin{array}{l}\text { Time for soil to recover to primary state from } \\
\text { "recovered" state }\end{array}$ & 1 & 1 \\
\hline $\begin{array}{l}\text { Fraction of original vegetation assigned to decay } \\
\text { pools at time of clearing }\end{array}$ & & \\
\hline 1-year & 0.4 & 0.4 \\
\hline 10-year & 0.27 & 0.27 \\
\hline 100 -year & 0.0 & 0.0 \\
\hline 1000-year & 0.0 & 0.0 \\
\hline Fraction left to decay on site & 0.33 & 0.33 \\
\hline Rate constant for on-site decay & 0.5 & 0.3 \\
\hline
\end{tabular}

(Note: Carbon measurements in $10^{6} \mathrm{~g} / \mathrm{ha}$; time in years.) 
The data in Table 3 can be shown graphically with two curves that describe the changing amounts of carbon in soil and live vegetation following disturbance. Figure 3 shows a reduction in the amount of carbon in live vegetation following clearing. Some of the carbon removed is placed in long-term storage in buildings, crates, etc.; some is burned as fuel wood and released immediately to the atmosphere; and some is left on the ground as slash or live underbrush. The carbon in the soil declines over several years following clearing until it reaches a new equilibrium. Abandonment of the area allows the regrowth of vegetation and a reaccumulation of carbon in the soil. Accumulation of carbon will continue until initial levels are reestablished.

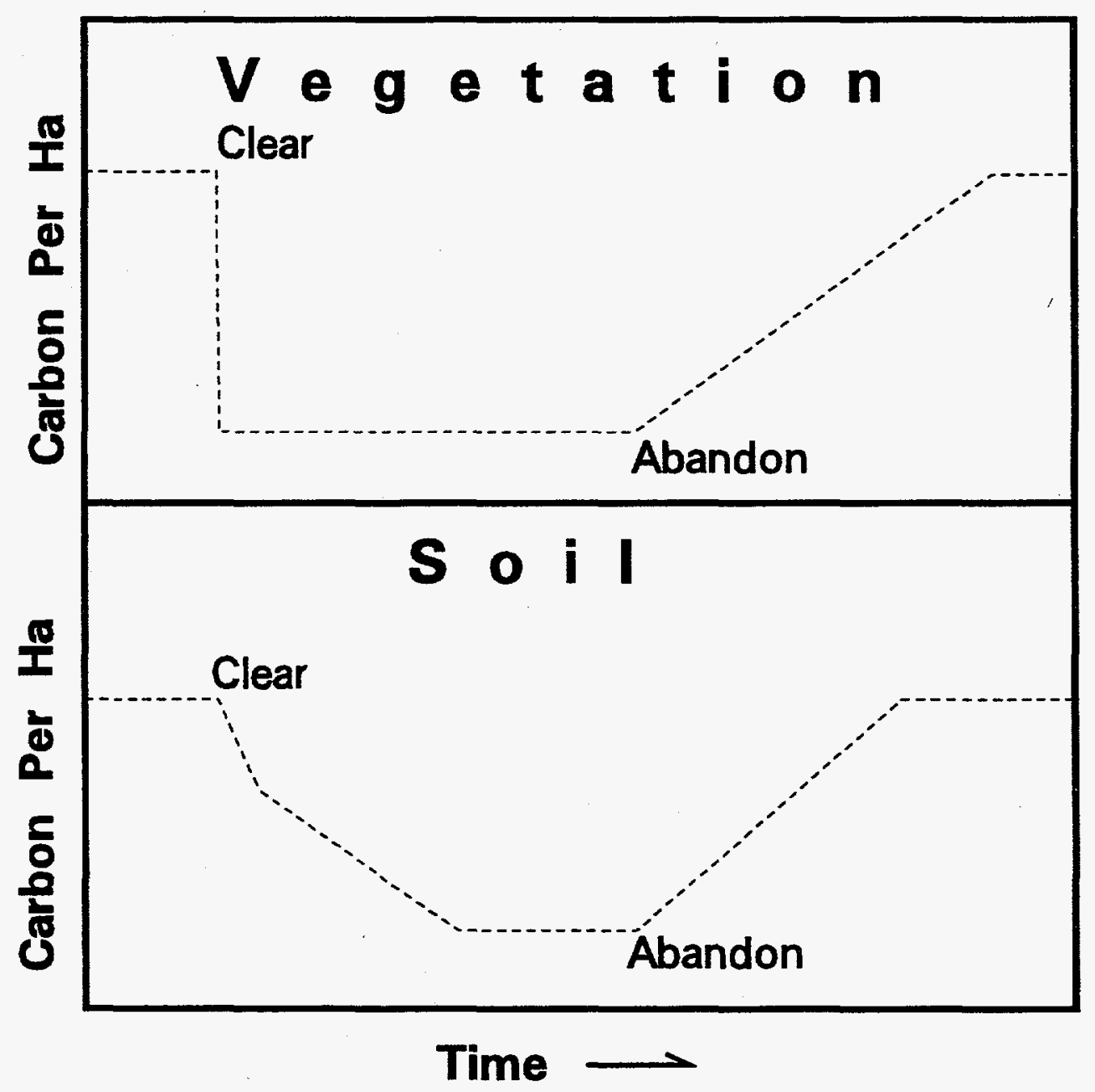

Figure 3. Changes in the carbon content of living vegetation and soils: clearing, abandonment, and regrowth. 


\subsection{The Carbon Flux Model}

The rates of land cover change and the response curves described in Section 7.1 are used in the carbon flux model to calculate the net transfer of carbon between the atmosphere and terrestrial ecosystems in each region. Ecosystems and regions with no net transfer of carbon to or from the atmosphere would be described by a line with a slope of zero. Because of this, only areas in states of transition need to be modeled. Those areas that have been harvested or cleared are modeled on an annual basis as the land moves along the appropriate response curve. These areas either remove carbon from the atmosphere as vegetation and soil accumulate organic matter, or release carbon as the soils are tilled and their organic matter oxidized. These response curves are defined for 1 ha of land; thus, the response curve is multiplied by the total land in each ecosystem in each region that is in transition. To this sum is added the carbon released from the oxidation of biomass contained in five decay pools.

For each ecosystem and region, the response curves describe the changes that occur to the carbon content of vegetation and soil for seven different forms of land cover change (i.e., clearing for cropland, pasture, shifting cultivation, industrial logging, nonindustrial logging, degradation, and afforestation). Figure 4 schematically describes the partitioning of biomass and carbon that occurs when forestland is cleared. The specific allocation of carbon is determined from the appropriate vegetation-soil response curve.

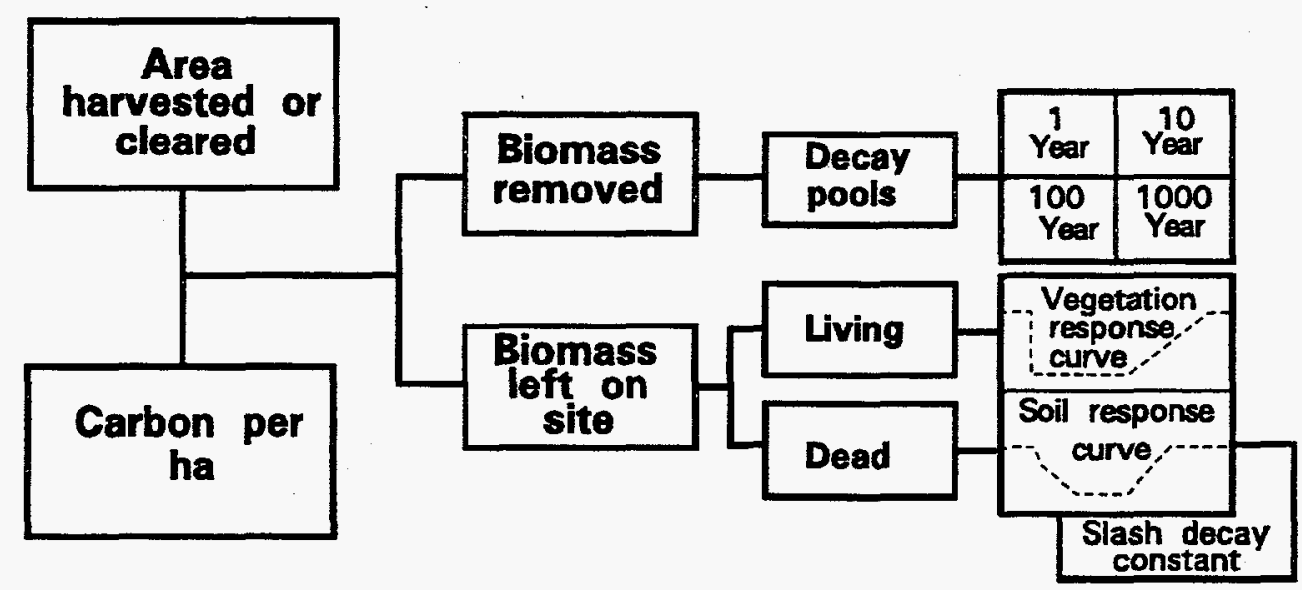

Figure 4. Schematic representation of the transfer of carbon and biomass that occurs when forested lands are cleared.

The carbon transfer shown in Fig. 4 is calculated using a bookkeeping model. The model tracks the annual transfer of carbon between soils, terrestrial ecosystems, and the atmosphere caused by changes in land cover. The model calculates the flux of carbon separately for each natural ecosystem and land cover change (disturbance) type in a region. These ecosystem fluxes are then summed to obtain the annual flux of carbon to or from the atmosphere for each region (Moore et al. 1981). These regional carbon flux totals are listed in Appendix C. 
The model is designed to track the transfer of forested lands to land uses with lower carbon contents (e.g., from tropical forest to pasture). During initial human habitation of a region, only undisturbed, high-carbon-content, primary forests are available for clearing. Once the minimum amount of land required for subsistence agriculture is obtained, more forests are cleared to obtain wood products. The primary forests harvested for wood products, unlike those cleared for agriculture, may be allowed to revert to forest and, with time, will recover to their previous high-carbon levels.

In modern agroforestry, trees are planted on previously cleared forestland and are allowed to grow for a few decades. These managed forests have a carbon content very close to that of the original primary forest when they have reached maturity (i.e., recovered) and are ready to be harvested (in 20 to 30-years) and will have the same carbon content as primary forests in 30 to 100 years.

In the bookkeeping carbon model, forestlands that have just recovered in a given year will be cleared before a similar undisturbed primary forest will be cleared. For example, the land cover rate curve for North America shows that $0.905 \times 10^{6}$ ha of temperate evergreen forest were logged in 1969, and the model has determined (based on the North America response curve) that 0.895 $\times 10^{6}$ ha of forest has "just recovered" from being logged in 1919 , thus the $0.895 \times 10^{6}$ ha of recovered forest will be recleared along with $0.01 \times 10^{6}$ ha of primary forest. This distinction is important because the recovered forest contains $25 \%$ less carbon than that of primary forest.

In the South and Southeast Asia region a differentiation has been made between undisturbed and degraded ecosystems. In South and Southeast Asia each forest ecosystem is represented by two pools of land (e.g., Degraded moist forest and Undisturbed moist forest). Similarly, separate land cover change rates and vegetation-soil response curves are provided. When a given amount of undisturbed forest is degraded (per the land cover change rate file for South and Southeast Asia) it is transferred to the degraded pool. The amount of carbon released is determined by subtracting the amount of "carbon in vegetation of undisturbed ecosystem" for the undisturbed forest from that of the disturbed forest. This carbon is then released based on the five decay pool definitions given in the undisturbed forest response curve. Note that during the conversion from undisturbed to disturbed land that the "carbon in soils of undisturbed ecosystems" does not change.

\subsection{Carbon Flux Equations}

The equations shown below were derived by CDIAC and are approximations of the formulas used to determine the carbon flux from land cover change in the computerized bookkeeping model. These equations are provided to assist users of this numeric data package in understanding how the carbon flux data were calculated.

The flux of carbon for an ecosystem is calculated separately for each given response curve and the carbon fluxes are aggregated to obtain the total carbon flux. These ecosystem totals are summed to obtain the regional carbon flux for each year. In general, Eq. 1 shows how the annual carbon flux (CF) with the atmosphere for a given ecosystem is calculated.

$$
\text { CF }=\text { Soil }_{r}+\text { Slash }_{r}+\text { P1 } r+P 10_{r}+\text { P100 }_{r}+\text { P1000 }_{r}-C_{a}
$$

where Soil ${ }_{r}$ is the carbon released from disturbed soil, Slash ${ }_{T}$ is the carbon released from dead 
vegetation left on-site after clearing, P1 through P1000 contain the amount of carbon released from the 1,10,100, and 1000-year decay pools, and $C_{a}$ is the amount of carbon removed from the atmosphere from the regrowth and recover of vegetation and soils. The contribution of each term varies as a function of pool size or time since disturbance.

In most types of land use change (e.g., clearing for cropland, pasture, shifting cultivation) Soil $l_{r}$ is calculated as follows:

$$
\begin{array}{ll}
\text { Soil }_{r} \text { in } X= & \sum X \text { to } X-\left(T_{R C}-1\right)\left[L C \cdot\left(\left(C_{U S}-C_{R C}\right) / T_{R C}\right)\right]+ \\
\sum X X T_{R C} \text { to } X-T_{S M}\left[L C \cdot\left(\left(C_{R C}-C_{S M}\right) /\left(T_{S M}-T_{R C}\right)\right]\right.
\end{array}
$$

where $\mathbf{L C}_{\mathrm{X}}$ is the amount of land cleared in year $\mathrm{X}, \mathrm{C}_{U S}$ is the amount of carbon per hectare in undisturbed soils, $C_{R C}$ is the amount of carbon per hectare remaining in the soil after the initial rapid change following clearing, $T_{R C}$ is the time for the rapid change in soil carbon to occur, $T_{S M}$ is the time to reach the minimum soil carbon content, and $\mathrm{C}_{\mathrm{SM}}$ is the minimum soil carbon content. Some forms of logging (nonindustrial) and in the special case of forest degradation Soil was assumed to have a value of zero.

The release of carbon to the atmosphere from Slash in year $\mathbf{X}$ is calculated based on a running total of the slash pool. The rate of decay for slash is constant for each response curve, unlike the release for soil, which has an initial rapid decay rate that is used for 1 to 10 years followed by a much lower rate that may be used for several decades. Use of a constant rate greatly simplifies the equation needed to calculate the carbon emissions from slash. Equations $3 \mathrm{a}$ and $3 \mathrm{~b}$ show how the annual amount of carbon released to the atmosphere from slash is calculated:

$$
\begin{gathered}
\text { Slash Pool }=\mathrm{LC}_{\mathrm{X}} \cdot \mathrm{C}_{\mathrm{UV}} \cdot \mathrm{F}_{\mathrm{CS}}+\left(\text { Slash } \text { Pool }_{\mathrm{X}-1}-\text { Slash }_{\mathrm{r}} \text { in } \mathrm{X}-1\right) \\
\text { Slash }_{\mathrm{r}} \text { in } \mathrm{X}=\text { Slash Pool } \bullet\left(1-\mathrm{e}^{-\mathrm{DR}}\right)
\end{gathered}
$$

where $\mathrm{LC}_{\mathrm{X}}$ is the amount of land cleared in year $\mathrm{X}, \mathrm{C}_{\mathrm{uv}}$ is the amount of carbon per hectare in an undisturbed ecosystem, $F_{C S}$ is the fraction of $C_{U V}$ that became slash following clearing, and $D R$ is the on-site decay rate for slash.

The equation for the release of carbon from the 1-year decay pool (P1) is based on the assumption that all carbon assigned to this pool will be used as fuel or burned on-site in the year following clearing. The equation for this pool is as follows:

$$
P 1 \text { in } X=\quad \mathrm{LC}_{\mathrm{X}-1} \cdot \mathrm{C}_{\mathrm{UV}} \cdot \mathrm{F}_{\mathrm{C1}}
$$

where $\mathrm{F}_{\mathrm{C} 1}$ is the fraction of $\mathrm{C}_{\mathrm{UV}}$ that is assigned to the 1-year decay pool following clearing.

The equations for the 10-, 100-, and 1000-year decay pools (P10, P100, P 1000) are similar to those shown in Eqs. $3 \mathrm{a}$ and $3 \mathrm{~b}$. The primary difference between the equations for P10, $\mathrm{P} 100$, and P1000 and Eq. $3 \mathrm{~b}$ is that the exponent in Eq. $3 \mathrm{~b}$ is not used. Equations $5 \mathrm{a}$ and $5 \mathrm{~b}$ show the formula used for calculating P10 in year X. 


$$
\begin{array}{cc}
\text { P10 Pool }= & \text { LC }_{\mathrm{X}} \cdot \mathrm{C}_{\mathrm{UV}} \cdot \mathrm{F}_{\mathrm{CP10}}+\left(\text { P10 } \text { Pool }_{\mathrm{X}-1}-\mathrm{P1O}_{\mathrm{r}} \text { in X }-1\right) \\
& \text { P10 in X }=\text { P10 Pool } \bullet \text { DR }
\end{array}
$$

where $F_{C P 10}$ is the fraction of $C_{U v}$ assigned to the 10-year decay pool and DR is the decay rate constant for P10 (in this case DR equals 0.1). Modification of this equation for the 100 - and 1000-year decay pools only requires that the appropriate fraction and decay constant be inserted (i.e., 0.01 or 0.001 for DR) in Eqs. 5 a and $5 b$, respectively.

The five equations shown above are used to determine the release of carbon to the atmosphere from the clearing of an ecosystem. There may also be an accumulation of carbon in live vegetation and in the soil from the abandonment of crop or pasture lands, and the regrowth of forests after logging. When land is abandoned, a linear function is used that transfers carbon from the atmosphere to live vegetation and into the soil. In some cases, the regrowth of forests after logging affected only the amount of carbon sequestered in live vegetation as the carbon content of soils was assumed to be unaffected by short-term disruptions caused by nonindustrial logging.

Removal of carbon from the atmosphere from the regrowth of vegetation on previously cleared land is calculated in this model using the following equation:

$$
\mathrm{C}_{\mathrm{a}} \text { in } \mathrm{X}=\mathrm{Crop}_{\mathrm{a}}+\mathrm{Soil}_{\mathrm{a}}+\mathrm{Veg}_{\mathrm{a}}
$$

where Crop is the amount of carbon removed by the growth of annual or perennial species on previously cleared forestland (or the amount of live vegetation left on-site after logging), Soil ${ }_{a}$ is the amount of carbon sequestered in the soil, and $\mathrm{Veg}_{\mathrm{a}}$ is the amount of carbon removed by the regrowth of woody vegetation on previously cleared land.

The amount of carbon removed by Crop $\mathrm{a}$ is a one-time removal, because the amount removed/released during the planting/harvesting/grazing cycle will be relatively constant from year to year. The equation for Crop $\mathrm{p}_{\mathrm{a}}$ is as follows:

$$
\text { Crop }_{\mathbf{s}} \text { in } \mathbf{X}=\mathbf{L C}_{\mathbf{X}} \cdot \mathbf{C}_{\text {crop }}
$$

where LC is the amount of land cleared for cropland or pasture in year $\mathrm{X}$ and $\mathrm{C}_{\text {crop }}$ is the amount of carbon per hectare associated with the major crop or fodder grown in the given region in the given ecosystem.

The Soil ${ }_{\mathrm{a}}$ and $\mathrm{Veg}_{\mathrm{a}}$ functions are used only if a previously cleared area is abandoned and allowed to return to its previous vegetation cover (if an area is logged and immediately abandoned sometimes only the $\mathrm{Veg}_{\mathrm{a}}$ equation is used). The Soil $\mathrm{a}_{\mathrm{a}}$ and $\mathrm{Veg}_{\mathrm{a}}$ equations, shown below, are used to calculate the transfer of carbon from the atmosphere into the soil and vegetation that occurs during the recovery of a natural ecosystem:

$$
\begin{aligned}
& \text { Soil }_{\mathbf{a}} \text { in } \mathrm{X}=\quad \sum \mathrm{X} \text { to } \mathrm{X}-\left(\mathrm{T}_{\mathrm{SR}}-1\right)\left[\mathrm{LA} \cdot\left(\left(\mathrm{C}_{\mathrm{RS}}-\mathrm{C}_{\mathrm{SM}}\right) / \mathrm{T}_{\mathrm{SR}}\right)\right] \\
& \mathrm{Veg}_{\mathrm{a}} \text { in } \mathrm{X}=\sum \mathrm{X} \text { to } \mathrm{X}-\left(\mathrm{T}_{\mathrm{VR}}-1\right)\left[\mathrm{LA} \cdot\left(\left(\mathrm{C}_{\mathrm{RV}}-\mathrm{C}_{\text {crop }}\right) / \mathrm{T}_{\mathrm{VR}}\right)\right]
\end{aligned}
$$


where LA is the amount of land abandoned in a given year, $C_{R S}$ is the soil carbon content of a recovered ecosystem, $\mathrm{C}_{\mathrm{SM}}$ is the minimum soil carbon content of a disturbed ecosystem, $T_{S R}$ is the time required for an abandoned system to recover, $C_{R V}$ is the vegetation carbon content of a recovered ecosystem, and $T_{\mathrm{VR}}$ is the time required for the vegetation in an abandoned system to recover. In some regions a distinction is made between a "recovered" ecosystem and an undisturbed system. In those cases equations similar to Eqs. 8 and 9 are used to bring the carbon content up from $C_{R V}$ to $C_{U V}$ over a period $T_{U R}$ (i.e., time for vegetation to recover to the undisturbed state from "recovered").

\subsection{Advantages of this Model}

Time lags associated with the decay and regrowth of vegetation and with the decay and recovery of soils make the annual flux of carbon calculated with this model more realistic than a flux derived by simple direct transfer methods that work on the assumption that all carbon in cleared vegetation is immediately released. There are several advantages of this carbon flux model over the more complicated process-type models. First, complex physiological and ecological processes do not have to be modeled since these processes are implicitly included in the shape of the response curves. Second, the information needed to construct the response curves is readily available in the literature. Third, the shape of the response curve for any ecosystem may be directly measured in the field. Once the response curve is constructed, the flux of carbon to the atmosphere can be determined based on the type of ecosystem cleared, the amount of land cleared, and the allocation of biomass to the five decay pools (Houghton et al. 1983, Moore et al. 1981). 


\section{LIMITATIONS AND RESTRICTIONS OF THE DATA}

The following list shows the caveats that should be considered when these data are used. Failure to consider these limitations may result in erroneous interpretation of the data.

(1) The large number of data sources used in determining the rates of land cover change precluded the checking of all data values.

(2) In 1700 (or 1850 in some regions), the initial land area in each natural ecosystem was approximated and then was reduced based on regional ratios of agricultural land to population (McEvedy and Jones 1978).

(3) Area estimates for each ecosystem, in each region, have been used to construct the annual land cover change curves that were entered into the carbon flux model. Data for years with missing data were derived by assuming constant rates of land clearing or by using a linear regression function between years with data. Thus, over the 120 years covered in this database, as few as four actual data values have been used to reconstruct rates of land cover change for a region.

(4) The amount of carbon in an undisturbed ecosystem was assumed to be constant. Thus, the total land area in a natural ecosystem within a region is not important, only the amount of land that changed status (e.g., from tropical evergreen forest to cropland).

The steady state assumption means that the estimates of carbon flux apply only to deliberately changed ecosystems and not to all ecosystems. For example, recently glaciated areas may still be accumulating carbon (Billings et al. 1982), or terrestrial respiration rates may have increased as a result of the higher concentration of $\mathrm{CO}_{2}$ in the atmosphere. These carbon sinks have been ignored by the model and are not reflected in the carbon flux estimates provided with this NDP.

(6) The equations contained in this document are approximations of those used in the computerized carbon flux model. As such, carbon flux values calculated using these equations may vary by $\pm 10 \%$ from those produced by the computer model. This error range, however, is within the inherent error of the land cover change and response curve data used in the computer model. 


\section{DATA CHECKS PERFORMED BY CDIAC}

An important part of the data packaging process at the Carbon Dioxide Information Analysis Center (CDIAC) is the quality assurance (QA) of the data. The QA process is an important component in the value-added concept of assuring accurate, usable information for researchers. The complete QA of a data set can be a time consuming process because data received by CDIAC are rarely in condition for immediate distribution, regardless of source. The following summarizes the QA checks performed on the various data groups presented in this document.

(1) The rates of land cover change for all forested ecosystem types in each region were combined for the periods 1958-1963 and 1979-1989 and compared to rates independently derived by the Food and Agriculture Organization (FAO 1960, 1966, 1980, 1990).

(2) Rates of land cover change were applied to the initial area in each ecosystem in 1850 (or 1700 when available) to produce ecosystem areas for the period 1850-1980. The estimated areas of each ecosystem were then compared for the years 1950 and 1980 with Paterson (1956), Lanly (1982), and FAO (1980).

(3) The data values in the soil and biomass response curves were compared with the original literature sources used in their compilation.

(4) The carbon fluxes from each ecosystem in Tropical Africa and the Former Soviet Union were recalculated using the equations contained in this document. These fluxes were then summed and compared to those provided by the principal investigators.

QA tasks 1 and 2 were conducted to check for errors in the land cover change data. All discrepancies between the FAO land cover values and those provided by the data contributors (QA task 2) were resolved. Task 3 was conducted to ensure that data entry errors had not occurred while transferring data from the original data sources cited in this document. The last task was conducted to ensure the carbon flux equations shown in this document approximated the values obtained by the more complicated carbon flux model used by the principal investigators. (The carbon flux data distributed with this database were produced by the their carbon flux model.) 


\title{
10. HOW TO OBTANN THESE DATA AND ITS DOCUMENTATION
}

This document describes the historical land cover and carbon flux data collected by Dr. Richard A. Houghton and Joseph L. Hackler for the U.S. Department of Energy's Global Climate Change Research Program. Their computerized data are available on 9-track magnetic tape, Exabyte 8-mm tape, QIC 0.25" tape cartridges, IBM DOS-compatible floppy diskettes (3.5" or 5.25" diskettes), and through an anonymous file transfer protocol (FTP) service from CDIAC. Requests for magnetic media should include any specific instructions required by the user and/or the user's local computer system. Requests for this data package should be addressed to

\author{
Carbon Dioxide Information Analysis Center \\ Oak Ridge National Laboratory \\ P.O. Box 2008 \\ Oak Ridge, Tennessee 37831-6335 \\ U.S.A.
}

Telephone: (615) 574-0390 or 574-3645

FAX: (615) 574-2232

\section{BITNET: CDIAC@ORNLSTC INTERNET: CDIAC@ORNL.GOV}

The data files may be acquired via the Internet from CDIAC's anonymous FTP server as follows:

- $\quad$ FTP to CDIAC.ESD.ORNL.GOV (128.219.24.36).

- Enter "anonymous" as the user id.

- Enter your electronic mail address as the password (e.g., BIRDWELL@ORNL.GOV).

- $\quad$ Change the directory using "cd pub/ndp050".

- $\quad$ Set FTP to get ASCII files by using the FTP "ascii" command.

- $\quad$ Acquire the ASCII descriptive file by using the FTP "mget ndp050.des" command.

- $\quad$ Change the directory using "cd ascii".

- $\quad$ Acquire the ASCII data files and I/O files by using the FTP "mget *" command.

- Change the directory using "cd ../wk1".

- $\quad$ Set FTP to get the binary Lotus ${ }^{\mathrm{TM}}$ files by using the FTP "binary" command.

- $\quad$ Acquire the binary Lotus 1-2-3 ${ }^{\mathrm{TM}}$ data files using the FTP "mget *.wk1" command.

- $\quad$ Exit the system by using the FTP "quit" command.

- Contact CDIAC by phone, fax, or electronic mail to order a hard copy of this documentation. 


\section{REFERENCES AND DATA SOURCES}

\subsection{Literature Cited}

Billings, W. D., J. O. Luken, D. A. Mortensen, and K. M. Peterson. 1982. Arctic tundra: a source or sink for atmospheric carbon dioxide in a changing environment? Oecologia 53:7-11.

Espenshade, E. B., Jr. 1986. Goode's World Atlas. 17th ed. Rand McNally and Company, Chicago.

Food and Agriculture Organization (FAO). 1960. World Forest Inventory - 1958. Forestry and Forest Products Division, FAO, Rome.

FAO. 1966. World Forest Inventory - 1963. Forestry and Forest Products Division, FAO, Rome.

FAO. 1980. FAO Production Yearbook. Statistics Division, FAO, Rome.

FAO. 1985. Yearbook of Forest Products. FAO, Rome.

FAO. 1990. FAO Production Yearbook. Statistics Division, FAO, Rome.

Gifford, R .M. 1992. pp. 151-187. In Australia's Renewable Resources: Sustainability and Global Change. Division of Plant Industry, Commonwealth Scientific and Industrial Research Organization, Canberra, Australia.

Hall, C. A. S., S. Brown, F.M. O'Hare, P. B. Bogdonoff, D. Barshaw, E. Kaufman, and S. Underhill. 1988. Bibliography of Tropical Rain Forests and the Global Carbon Cycle: I. An Introduction to the Literature. ORNL/CDIAC-24/V1, Oak Ridge National Laboratory, Oak Ridge, Tennessee.

Houghton, R. A., J. E. Hobbie, J. M. Melillo, B. Moore, B. J. Peterson, G. R. Shaver, and G. M. Woodwell. 1983. Changes in the carbon content of terrestrial biota and soils between 1860 and 1980: a net release of $\mathrm{CO}_{2}$ to the atmosphere. Ecological Monographs 53:235-262.

Houghton, R. A., R. D. Boone, J. M. Melillo, C. A. Palm, G. M. Woodwell, N. Myers, B. Moore and D. L. Skole. 1985. Net flux of carbon dioxide from tropical forests in 1980. Nature 316:617-620.

Houghton, R. A., R. D. Boone, J. R. Fruci, J. E. Hobbie, J. M. Melillo, C. A. Palm, B. J. Peterson, G. R. Shaver, G. M. Woodwell, B. Moore, D. L. Skole, and N. Myers. 1987. The flux of carbon from terrestrial ecosystems to the atmosphere in 1980 due to changes in land use: Geographic distribution of the global flux. Tellus 39B:122-139.

Houghton, R.A. and D. L. Skole. 1990. Carbon. pp. 393-408. In The Earth Transformed by Human Action, Turner, B. L., W. C. Clark, R. W. Kates, J. F. Richards, J. T. Mathews, and W. B. Meyer (eds.). Cambridge University Press, Cambridge, England. 
Houghton, R. A. 1991a. Releases of carbon to the atmosphere from degradation of forests in tropical Asia. Canadian Journal of Forest Research 21:132-142.

Houghton, R. A. 1991b. Tropical deforestation and atmospheric carbon dioxide. Climatic Change 19:99-118.

Houghton, R. A., D. S. Lefkowitz, and D. L. Skole. 1991a. Changes in the landscape of Latin America between 1850 and 1985: I. Progressive loss of forests. Forest Ecology and Management 38:143-172.

Houghton, R. A., D. L. Skole, and D. S. Lefkowitz. 1991b. Changes in the landscape of Latin America between 1850 and 1985: II. Net release of $\mathrm{CO}_{2}$ to the atmosphere. Forest Ecology and Management 38:173-199.

Houghton, R. A. 1993. Changes in terrestrial carbon over the last 135 years. pp. 139-157. In The Global Carbon Cycle, Heunabb, M. (ed.). Springer-Verlag, New York.

Houghton, R. A. and J. L. Hackler. 1994. The net flux of carbon from deforestation and degradation in South and Southeast Asia. pp. 301-327. In Effects of Land-Use Change on Atmospheric $\mathrm{CO}_{2}$ Concentrations, Dale, V. H. (ed.). Springer-Verlag, New York.

Keeling, C. D. and T. P. Whorf. 1994. Atmospheric $\mathrm{CO}_{2}$ records from sites in the SIO air sampling network. pp. 16-26. In Trends'93: A Compendium of Data on Global Change, Boden, T. A., C. P. Kaiser, R. J. Sepanski, and F. W. Stoss (eds.). ORNL/CDIAC-065, Carbon Dioxide Information Analysis Center, Oak Ridge National Laboratory, Oak Ridge, Tennessee.

Lanly, J.-P. 1982. Tropical Forest Resources. Forestry Paper 30, FAO, Rome.

Marland, G. and R. M. Rotty. 1984. Carbon dioxide emissions from fossil fuels: A procedure for estimation and results for 1950-1982. Tellus 36B:232-261.

McEvedy, C. and R. Jones. 1978. Atlas of World Population History. Penguin Books, Middlesex, England.

Melillo, J. M., J. R. Fruci, R. A. Houghton, B. Moore, and D. L. Skole. 1988. Land-use change in the Soviet Union between 1850 and 1980: Causes of a net release of $\mathrm{CO}_{2}$ to the atmosphere. Tellus 40B:116-128.

Moore, B., R. D. Boone, J. E. Hobbie, R. A. Houghton, J. M. Melillo, B. J. Peterson, G. R. Shaver, C. J. Vörösmarty, and G. M. Woodwell. 1981. A simple model for analysis of the role of terrestrial ecosystems in the global carbon budget. pp. 365-385. In Modelling the Global Carbon Cycle, Bolin, B. (ed.). SCOPE 16, Scientific Committee on Problems of the Environment of the International Council of Scientific Unions, John Wiley and Sons, New York.

Olson, J. S., J. A. Watts, and L. J. Allison. 1983. Carbon in Live Vegetation of Major World Ecosystems. TR004, DOE/NBB-0037, Office of Energy Research, Office of Basic Energy Research, Carbon Dioxide Research Division, U.S. Department of Energy, Washington, D.C. 
Palm, C. A., R. A. Houghton, J. M. Melillo, and D. L. Skole. 1986. Atmospheric carbon dioxide from deforestation in Southeast Asia. Biotropica 18:177-188.

Paterson, S. S. 1956. The Forest Area of the World and Its Potential Productivity. Department of Geography, The Royal University of Göteborg, Sweden.

Patrinos, A. 1993. Global Change Research: Summaries of Research in FY 1993. DOE/ER-0597T, UC-402, Office of Energy Research, Office of Health and Environmental Research, Environmental Science Division, Washington, D.C.

Richards, J. A. and E. P. Flint. 1994. Historic Land Use and Carbon Estimates for South and Southeast Asia: 1880-1980. ORNL/CDIAC-61, NDP-046, Oak Ridge National Laboratory, Oak Ridge, Tennessee.

Schlesinger, W. H. 1984. Soil organic matter: A source of atmospheric $\mathrm{CO}_{2}$. pp. 111-127. In The Role of Terrestrial Vegetation in the Global Carbon Cycle: Measurement by Remote Sensing, Woodwell, G.M. (ed.). John Wiley and Sons, New York.

Schlesinger, W. H. 1986. Changes in soil carbon storage and associated properties with disturbance and recovery. pp. 194-220. In The Changing Carbon Cycle: A Global Analysis, Trabalka, J. R. and D. E. Reichle (eds.). Springer-Verlag, New York.

Whittaker, R. H. and G. E. Likens. 1973. Carbon in the biota. pp. 281-302. In Carbon and the Biosphere, Woodwell, G. M. and E. V. Pecan (eds.). Proceedings of the 24th Brookhaven Symposium in Biology, CONF-720510, U.S. Atomic Energy Commission, Springfield, Virginia.

Woodwell, G. M. (ed.) 1984. The Role of Terrestrial Vegetation in the Global Carbon Cycle: Measurement by Remote Sensing. SCOPE 23, Scientific Committee on Problems of the Environment of the International Council of Scientific Unions, John Wiley and Sons, New York.

Zinke, P. J., A. G. Stangenberger, W. M. Post, W. R. Emanuel, and J. S. Olson. 1986. Worldwide Organic Soil Carbon and Nitrogen Data. ORNL/CDIAC-18, NDP-018, Oak Ridge National Laboratory, Oak Ridge, Tennessee.

Zon, R. and W. Sparhawk. 1923. Forest Resources of the World. McGraw-Hill, New York. 


\subsection{Data Sources}

\subsubsection{Global}

Ajtay, G. L., P. Ketner, and P. Duvigneaud. 1979. Terrestrial primary production and phytomass. pp. 129-182. In The Global Carbon Cycle, Bolin, B., E. T. Degens, S. Kempe, and P. Ketner (eds.). John Wiley and Sons, New York.

Arnold, J. E. M. and J. Jongma. 1978. Fuelwood and charcoal in developing countries. Unasylvia 29:2-9.

Brown, S. and A. E. Lugo. 1984. Biomass of tropical forests: A new estimate based on volumes. Science 223:1290-1293.

Brown, S., A. J. R. Gillespie, and A. E. Lugo. 1989. Biomass estimation methods for tropical forests with applications to forest inventory data. Forest Science 35:881-902.

Buringh, P. 1984. Organic carbon in soils of the world. pp. 91-109. In The Role of Terrestrial Vegetation in the Global Carbon Cycle: Measurement by Remote Sensing, Woodwell, G. M. (ed.). John Wiley and Sons, New York.

Covington, W. W. 1981. Changes in forest floor organic matter and nutrient content following clear cutting in northern hardwoods. Ecology 62:41-48.

Espenshade, E. B., Jr. (ed.). 1987. Goode's World Atlas (Global soil, climate, and vegetation maps). 17th ed., Rand McNally, Chicago.

Food and Agricultural Organization (FAO). 1948. Forest Resources of the World - 1947. Unasylva 2(4) and 4(4).

FAO. 1948. Forest resources of the world. Unasylva 2:160-182.

FAO. 1949-1991. FAO Production Yearbook (1948-1990). Statistics Division, FAO, Rome.

FAO. 1955. World Forest Resources - 1953. Forestry and Forest Products Division, FAO, Rome.

FAO. 1960. World Forest Inventory - 1958. Forestry and Forest Products Division, FAO, Rome.

FAO. 1966. World Forest Inventory - 1963. Forestry and Forest Products Division, FAO, Rome.

FAO. 1981. Forest Resources of Tropical America, Asia, and Asia: A Summary. Tropical Forest Resources Assessment Project (in the framework of the Global Environmental Monitoring System), FAO and United Nations Environment Programme, Rome.

FAO. 1985. Yearbook of Forest Products. FAO, Rome. 
FAO. 1990. Interim Report on the Tropical Forest Resources Assessment - 1990. Committee on Forestry, FAO, Rome.

FAO. 1991. Second Interim Report on the State of Tropical Forests. 10th World Forestry Congress, Paris, France.

Fleuret, P. and A. Fleuret. 1978. Fuelwood use in a peasant community: Tanzanian case study. Journal of Developing Areas 12:315-322.

Grigg, D. B. 1974. The Agricultural Systems of the World: An Evolutionary Approach. Cambridge University Press, Cambridge, England.

Hall, C. A. S. and J. Uhlig. 1991. Refining estimates of carbon release from tropical land-use change. Canadian Journal of Forest Research 21:118-131.

Houghton, R. A., J. E. Hobbie, J. M. Melillo, B. Moore, B. J. Peterson, G. R. Shaver, and G. M. Woodwell. 1983. Changes in the carbon content of terrestrial biota and soils between 1860 and 1980: A net release of $\mathrm{CO}_{2}$ to the atmosphere. Ecological Monographs 53:235-262.

Ilvessalo, L. and M. Jalava. 1930. Forest Resources of the World. Editae 16, Communications Ex Instituto Queaestionum Forestalium Finlandiae, Helsinki.

International Institute of Agriculture (IIA). 1922. International Yearbook of Agricultural Statistics 1909-1921. IIA, Rome.

IIA. 1939. The First World Agricultural Census - 1930. 5 vols., IIA, Rome.

Kawaguchi, H. and K. Yoda. 1986. Carbon-cycling changes during regeneration of a deciduous broadleaf forest after clear-cutting: I. Changes in organic matter and carbon storage. Japanese Journal of Ecology 35:551-563.

Kononova, M. M. 1961. Soil Organic Matter: Its Nature, Its Role in Soil Formation and in Soil Fertility. Pergamon Press, New York.

Lanly, J.-P. 1982. Tropical Forest Resources. Forestry Paper 30, FAO, Rome.

Lee, C. K. and R. H. Bray. 1949. Organic matter and nitrogen contents of soils as influenced by management. Soil Science 68:203-212.

Lutz, H. J. and R. F. Chandler. 1946. Forest Soils. John Wiley and Sons, New York.

Marks, P. L. and F. H. Bormann. 1972. Revegetation following forest cutting: Mechanisms for returning to steady-state nutrient cycling. Science 176:914-915.

McEvedy, C. and R. Jones. 1978. Atlas of World Population History. Penguin Books, Middlesex, England. 
Moore, B., R. D. Boone, J. E. Hobbie, R. A. Houghton, J. M. Melillo, B. J. Peterson, G. R. Shaver, C. J. Vörösmarty, and G. M. Woodwell. 1981. A simple model for analysis of the role of terrestrial ecosystems in the global carbon budget. pp. 365-385. In Modelling the Global Carbon Cycle, Bolin, B. (ed.). SCOPE 16, Scientific Committee on Problems of the Environment of the Intemational Council of Scientific Unions, John Wiley and Sons, New York.

Nye, P. H. and D. J. Greenland. 1960. The Soil Under Shifting Cultivation. Technical Communication 51, Commonwealth Bureau of Soils, Harpenden, England.

Office of Technology Assessment. 1992. Combined Summaries: Technologies to Sustain Tropical Forest Resources and Biological Diversity. OTA-F-515, U.S. Government Printing Office, Washington, D.C.

Openshaw, K. 1974. Wood fuels the developing world. New Scientist 61:271-272.

Olson, J. S., J. A. Watts, and L. J. Allison. 1983. Carbon in Live Vegetation of Major World Ecosystems. TR004, DOE/NBB-0037, Office of Energy Research, Office of Basic Energy Research, Carbon Dioxide Research Division, U.S. Department of Energy, Washington, D.C.

Paterson, S. S. 1956. The Forest Area of the World and Its Potential Productivity. Department of Geography, The Royal University of Göteborg, Sweden.

Persson, R. 1974. World Forest Resources: Review of the World's Forest Resources in the early 1970's. Research Notes No. 17, Royal College of Forestry Survey, Stockholm.

Post, W. M., W. R. Emanuel, P. J. Zinke, and A. G. Stangenberger. 1982. Soil carbon pools and world life zones. Nature 298:156-159.

Richards, J. R. 1982. History of Global Land Clearing: 1860-1980. Institute for Energy Analysis, Oak Ridge Associated Universities, Oak Ridge, Tennessee.

Robertson, C. J. 1956. The expansion of the arable area. The Scottish Geographical Magazine $72: 1-20$.

Schlesinger, W. H. 1984. Soil organic matter: A source of atmospheric $\mathrm{CO}_{2}$. pp. 111-127. In The Role of Terrestrial Vegetation in the Global Carbon Cycle: Measurement by Remote Sensing, Woodwell, G. M. (ed.). John Wiley and Sons, New York.

Schlesinger, W. H. 1986. Changes in soil carbon storage and associated properties with disturbance and recovery. pp. 194-220. In The Changing Carbon Cycle: A Global Analysis, Trabalka, J. R. and D. E. Reichle (eds.). Springer-Verlag, New York.

Summer, A. 1976. Attempt at an assessment of the World's tropical forests. Unasylva 28:112-113.

Tucker, R. P. and J. R. Richards. 1983. Global Deforestation and the Nineteenth-century World Economy. Duke University Press, Durham, North Carolina. 
Whittaker, R. H. and G. E. Likens. 1973. Carbon in the biota. pp. 281-302. In Carbon and the Biosphere, Woodwell, G. M. and E. V. Pecan (eds.). Proceedings of the 24th Brookhaven Symposium in Biology, CONF-720510, U.S. Atomic Energy Commission, Springfield, Virginia.

Woodwell, G. M. (ed.). 1984. The Role of Terrestrial Vegetation in the Global Carbon Cycle: Measurement by Remote Sensing. SCOPE 23, Scientific Committee on Problems of the Environment of the Intemational Council of Scientific Unions, John Wiley and Sons, New York.

Zinke, P. J., A. G. Stangenberger, W. M. Post, W. R. Emanuel, and J. S. Olson. 1986. Worldwide Organic Soil Carbon and Nitrogen Data. ORNL/CDIAC-18, NDP-018, Oak Ridge National Laboratory, Oak Ridge, Tennessee.

Zon, R. and W. Sparhawk. 1923. Forest Resources of the World. McGraw-Hill, New York.

\subsubsection{North America}

Clawson, M. 1979. Forests in the long sweep of American history. Science 204:1168-1174.

FAO. 1990. Timber Trends and Prospects for North America. Forestry Department, FAO, Rome.

Giddens, J. 1957. Rate of loss of carbon from Georgia soils. Proceedings of the Soil Society of America 21:513-515.

Haas, G. J., C. F. Evans, and E. F. Miles. 1957. Nitrogen and Carbon Changes in Great Plains Soils as Influenced by Cropping and Soil Treatments. Technical Bulletin 1164, U.S. Department of Agriculture, Washington, D.C.

Hart, J. F. 1968. Loss and abandonment of cleared farm land in the eastern United States. Annals of the Association of American Geographers 58:417-440.

Hough, F. B. 1878. Report upon Forestry. 3 Vols., Commissioner of Agriculture, U.S. Government Printing Office, Washington, D.C.

Reynolds, R. V. and A. H. Pierson. 1942. Fuelwood used in the United States: 1630-1930. USDA Circular No. 641, U.S. Department of Agriculture, Washington, D.C.

U.S. Bureau of the Census. 1975. Historical Statistics of the United States: Colonial times to 1970. Part I, U.S. Govermment Printing Office, Washington, D.C. 


\subsubsection{South and Central America}

Banco do Brasil. 1967. Boletim estatistico, XXIV. Sao Paulo, Brazil.

Bartlett, H. H. 1956. Fire, primitive agriculture, and grazing in the tropics. pp. 692-720. In Man's Role in Changing the Face of the Earth, Thomas, W. L. (ed.). University of Chicago Press, Chicago.

Brunk, J. W. and H. Franklin. 1940. Brazil Yearbook and Manual 1940. New York.

Buschbacher, B. 1984. Changes in Productivity and Nutrient Cycling Following Conversion of Amazon Rainforest to Pasture. Dissertation. University of Georgia, Athens, Georgia.

Budowski, G. 1956. Tropical savannas, a sequence of forest felling and repeated burnings. Turrialba 6:23-33.

Carvalho, C. M. D. 1910. Le Bresil meridional. Rio de Janeiro, Brazil.

Centro Industrial do Brasil. 1908. O Brasil. II. Industria agricola. Rio de Janeiro, Brazil.

Cerri, C. C., B. Volkoff, and F. Andreux. 1991. Nature and behavior of organic matter in soils under natural forest and after deforestation, burning and cultivation near Manaus. Forest Ecology and Management 38:247-257.

Cole, M. M. 1960. Cerrado, caatinga and pantanal: The distribution and origin of the savanna vegetation of Brazil. Geography Journal 126:168-179.

Cunningham, R. K. 1963. The effect of clearing a tropical forest soil. Journal of Soil Science $14: 334-345$.

Dean, W. 1983. Deforestation in southeastern Brazil. pp 50-67. In Global Deforestation and the Nineteenth-Century World Economy, Tucker, R. P. and J. F. Richards (eds.). Duke University Press, Durham, North Carolina.

Departamiento de la Estadistica Nacional. 1931. Anuario de 1930. Mexico City.

Directoria Geral de Estatistica. 1933. Estatistica da producao industrial do Brasil, 1915-1929. Rio de Janeiro, Brazil.

Encuesta Agropecuaria Nacional. 1965. Departamento Administrativo Nacional de Estadistica. Bogota, Colombia.

Falesi, I. C. 1976. Ecossistema de Pastagem Cultivada na Amazonia Brasiliera. Belém, Centro de Pesquisa Agropecuario do Tropico Umido Brazil.

Fearnside, P. M. 1982. Deforestation in the Brazilian Amazon: How fast is it occurring? Interciencia 7:82-88. 
Fearnside, P. M. 1983. Land-use trends in the Brazilian Amazon region as factors in accelerating deforestation. Environmental Conservation 10:141-148.

Fearnside, P. M. 1990. Deforestation in Brazilian Amazonia. In The Earth in Transition: Patterns and Processes of Biotic Impoverishment, Woodwell, G. M. (ed.). Cambridge University Press, London.

Ferreira Soares, S. 1860. Notas estatisticas sobre a producao agricola e carestia dos generos alimenticios no imperio do Brasil. Rio de Janeiro, Brazil.

Folster, H. 1986. Forest-savanna dynamics and decertification processes in the Gran Sabana. Interciencia 11:311-316.

FAO. 1981. Forest Resources of Tropical America (Spanish). 2 parts, Tropical Forest Resources Assessment Project (in the framework of the Global Environmental Monitoring System), FAO and United Nations Environment Programme (UNEP), Rome.

FAO/UNEP. 1981. Proyecto de Evaluacion de los Recursos Forestales Tropicales. Los Recursos Forestales de la America Tropical. FAO, Rome.

da Fonseca, G. A. B. 1985. The vanishing Brazilian Atlantic forest. Biological Conservation $34: 17-34$.

Hecht, S. B. 1982a. Agroforestry in the Amazon Basin: Practice, theory and limits of a promising land use. pp. 331-371. In Amazonia Agriculture and Land Use Research, Hecht, S.B. (ed.). Centro Internacional de Agricultura Tropical, Cali, Colombia.

Hueck, K. and P. Seibert. 1972. Vegetationskarte von Siedamenika. Gustave Fischer Verlag, Stuttgart, Germany.

Instituto Brasileiro de Estatistica. 1969. Atualidade estatistica do Brasil 1969. Rio de Janeiro, Brazil.

Instituto Brasileiro de Geografia e Estatistica (IBGE). 1979. Censo Agropecuario. Rio de Janeiro, Brazil.

IBGE. 1936-1978. Anuario estatistico do Brasil. Rio de Janeiro, Brazil.

IBGE. 1967. Boletim estatistico, XCVIII. Rio de Janeiro, Brazil.

Instituto de Expansao Commercial. 1930. O Brasil Actual. Rio de Janeiro, Brazil.

International Institute of Agriculture. 1915-1946 (annual). International Yearbook of Agricultural Statistics. Rome. 
Kohlhepp, G. 1984. Development planning and practices of economic exploitation in Amazonia. pp. 649-674. In The Amazon. Limnology and Landscape Ecology of a Mighty Tropical River and its Basin, Sioli, H. (ed.). Monographiae Biologicae 56, Dr W. Junk Publishers, Boston, Massachusetts.

Krebs, J. E. 1975. A comparison of soils under agriculture and forests in San Carols, Costa Rica. pp. 381-390. In Tropical Ecological Systems, Vol. 11, Golley, F. B. and E. Medina (eds.). Springer-Verlag, New York.

Kugler, W. F. 1968. Meridiano agricola argentino. Buenos Aires, Argentina.

Lang, G. E. and D. H. Knight. 1979. Decay rates for tropical trees in Panama. Biotropica 11:316-317.

Lanly, J.-P. 1985. Defining and measuring shifting cultivation. Unasylva 37:17-21.

McNeill, J. R. 1988. Deforestation in the Araucaria zone of southem Brazil, 1900-1983. pp. 15-32 and 263-266. In World Deforestation in the Twentieth Century, Richards, J. F. and R. P. Tucker (eds.). Duke University Press, Durham, North Carolina.

Ministerio da Agricultura, Industria e Commercio. 1923. Recenseamento do Brasil. Vol. III, Rio de Janeiro, Brazil.

Ministerio de Agricultura y Cria. 1979. Anuario Estadistico Agropecuaria, 1978. Ministerio de Agricultura y Cria. Caracas, Venezuela.

de Montalembert, M. R. and J. Clement. 1983. Fuelwood supplies in the developing countries. FAO Forestry Paper No. 42, FAO, Rome.

Mulhall, M. G. and E. T. Mulhall. 1877. Handbook of Brazil. Buenos Aires, Argentina.

Myers, N. and R. Tucker. 1987. Deforestation in Central America: Spanish legacy and North American consumers. Environmental Review 11:55-71.

Nacional Financiera, S. A. 1966. Statistics on the Mexican Economy. Mexico City.

Oakenfull, J. S. 1912. Brazil in 1911. London.

Phillips, J. 1961. The Development of Agriculture and Forestry in the Tropics: Patterns, Problems and Promise. Faber \& Faber, London.

Popenoe, H. 1957. The influence of the shifting cultivation cycle on soil properties in Central America. Proceedings of the Pacific Science Congress 9:72-77.

Sanchez, P. A., D. E. Bandy, J. H. Villachica, and J. J. Nicholaides. 1982. Amazon basin soils: Management for continuous crop production. Science 216:821-827. 
Sanchez, P. A. (ed.) 1973. A Review of Soils Research in Tropical Latin America. Technical Bulletin 219, North Carolina Agricultural Experimentation Station, Raleigh, North Carolina.

Schuh, G. E. 1970. The Agricultural Development of Brazil. Praeger Publishers, New York.

Seubert, C. E., P. A. Sanchez, and C. Valverde. 1977. Effects of land clearing methods on soil properties of an ultisol and crop performance in the Amazon jungle of Peru. Tropical Agriculture (Trinidad) 54:307-321.

Sioli, H. 1984. Former and recent utilizations of Amazonia and their impact on the environment. pp. 675-706. In The Amazon. Limnology and Landscape Ecology of a Mighty Tropical River and its Basin, Sioli, H. (ed.). Monographiae Biologicae 56, Dr W. Junk Publishers, Boston, Massachusetts.

Snedaker, S. C., and J. F. Gamble. 1969. Compostional analysis of selected second-growth species from lowland Guatemala and Panama. Bioscience 19:536-538.

Sociedad Rural Argentina. 1928. Anuario. Buenos Aires, Argentina.

South American Intelligence Company. 1919. Os Estados Unidos do Brasil. London.

Stearman, A. M. 1983. Forest to pasture: Frontier settlement in the Bolivian lowlands. pp. 51-63. In The Dilemma of Amazonian Development, Moran, E. F. (ed.). Westview Press, Boulder, Colorado.

Tardin, A. T., D. C. Lee, R. J. R. Santos, O. R. de Assis, M. P. Barbosa, M. Moreira, M. T. Pereira, and C. P. Filho. 1980. Subprojecto desmatamento convenio. IBDF/CNP-INPE, Inst. de Pesquisais Espaciais, Sao Jose dos Campos, Brazil.

Tenenbaum, J. 1946. Orientacion economica de la agricultura argentina. Buenos Aires, Argentina.

Uh1, C. 1987. Factors controlling succession following slash-and-burn agriculture in Amazonia. Journal of Ecology 75:377-407.

Uhl, C. and R. Buschbacher. 1985. A disturbing synergism between cattle ranch burning practices and selective tree harvesting in the eastern Amazon. Biotropica 17:265-268.

Uhl, C., R. Buschbacher, and E. A. S. Serrao. 1988. Abandoned pastures in eastem Amazonia: I. Pattems of plant succession. Journal of Ecology 76:663-681.

Uhl, C., H. Clark, K. Clark, and P. Maquirino. 1982. Successional pattern associated with slashand-burn agriculture in the Upper Rio Negro region of the Amazon Basin. Biotropica 14:249-254.

U.S. Department of Agriculture.. 1958. Agricultural Geography of Latin America. Publication No. 743, U.S. Department of Agriculture, Washington, D.C. 
V. Censos Agricola-Ganadero y Ejidal 1970. Resumen General. Direction General de Estadistica. Mexico, City.

Vazquez-Presedo, V. 1971-1976. Estadisticas historicas argentinas. 2 vols. Buenos Aires, Argentina.

Watters, R. F. 1971. Shifting Cultivation in Latin America. Forest Development Paper 17, FAO, Rome.

Wilkie, J. (chief ed.). 1960-1981 (annual). Statistical Abstract of Latin America. Vols. 1-21, University of California Press, Los Angeles, California.

Yates, P. L. 1981. Mexico's Agricultural Dilemma. University of Arizona Press, Tucson.

\subsubsection{Europe}

FAO. 1953. European Timber Statistics: 1913-1950. Forestry and Forest Products Division, FAO, Rome.

FAO. 1986. European Timber Trends and Prospects to The Year 2000 and Beyond. Forestry Department, FAO, Rome.

Mitchell, B. R. 1975. European Historical Statistics 1750-1970. Macmillan, London.

Weck, J. and C. Wiebecke. 1961. Weltforstwirtschaft und Deutschlands Forstund Holzwirtschaft. BLV Verlagsgesellschaft, Munich, Germany.

\subsubsection{North Africa and the Middle East}

FAO. 1967. Timber Trends and Prospects in Africa. Forestry Department, FAO, Rome.

FAO. 1981. Forest Resources of Tropical Africa. 2 parts, Tropical Forest Resources Assessment Project (in the framework of the Global Environmental Monitoring System), FAO and United Nations Environment Programme, Rome.

Leach, G. and R. Mearns. 1977. Beyond the Wood Fuel Crisis: People, Land, and Trees in Africa. Earthscan Publications, London. 


\subsubsection{Tropical Africa}

Cunningham, R. K. 1963. The effect of clearing a tropical forest soil. Journal of Soil Science 14:334-345.

Detwiler, R. P. 1986. Land use change and the global carbon cycle: The role of tropical soils. Biogeochemistry 2:67-93.

FAO. 1967. Timber Trends and Prospects in Africa. Forestry Department, FAO, Rome.

FAO. 1981. Forest Resources of Tropical Africa. 2 parts, Tropical Forest Resources Assessment Project (in the framework of the Global Environmental Monitoring System), FAO and United Nations Environment Programme, Rome.

John, D. M. 1973. Accumulation and decay of litter and net production of forests in tropical West Africa. Oikis 24:430-435.

Keay, R. W. J. 1959. Vegetation Map of Africa South of the Tropic of Cancer with Explanatory Notes. UNESCO, London.

Leach, G. and R. Mearns. 1977. Beyond the Wood Fuel Crisis: People, Land, and Trees in Africa. Earthscan Publications, London.

White, F. 1980. Vegetation Map of Africa. Scale 1:5,000,000, UNESCO, Oxford, England.

\subsubsection{Former Soviet Union}

Barr, B. M. 1989. Deforestation in the USSR: Perspectives on factors affecting major regional forest areas and the volumes of timber. In The World Economy and World Forests in the Twentieth Century, Richards, J. F. and R. P. Tucker (eds.). University Press, Durham, North Carolina.

Blandon, P. 1983. Soviet Forest Industries. Westview Press, Boulder, Colorado.

Eronen, J. 1982. Soviet pulp and paper industry: Factors explaining its areal expansion. Silva Fennicant 3:267-285.

FAO. 1989. Outlook for the Forest and Forest Product Sector of the USSR. Forestry Department, FAO, Rome.

Keller, B. A. 1927. Distribution of vegetation on the plains of European Russia. Journal of Ecology 15(2):189-231.

Lydolph, P. E. 1970. Geography of the USSR, 2nd edition. John Wiley and Sons, New York. 
Soviet Union. 1956-1980 (annual), National Economy of the U.S.S.R.; A Statistical Compilation. TSentral'noe statisticheskoe upravlenie, Moscow.

Sutton, W. R. J. 1975. The forest resources of the USSR: Their exploitation and their potential. Forest Review 54:110-138.

Symons, L. 1972. Russian Agriculture. A Geographic Survey. John Wiley and Sons, New York.

Tseplyaev, V. P. 1965. The Forests of the USSR (Tr. A. Gourevitch). Daniel Davey, New York.

Vasil'ev, I. V. 1973. Structural and geographical advances in the industrial use of timber in the USSR. In Timber Bulletin for Europe. Supplement 2, 26:15-33. United Nations Economic Commission for Europe and FAO, Geneva.

Yatsunskiy, V. K. 1982. Changes in the distribution of agriculture in European Russia from the end of the 18th century until WW II. Soviet Geographic Review 23:251-269 and 23:326-345.

\subsubsection{China}

Deying, X. 1992. Carbon Emissions and Sequestration in Forests: Case Studies from Seven Developing Countries. Vol. 3. Lawrence Berkeley Laboratory, University of Califomia, Berkeley, California.

Institute of Soil Science. 1978. Soils of China. Science Press, Beijing, China.

Murphy, R. 1983. Deforestation in modem China. pp. 111-128. In Global Deforestation and the Nineteenth-Century World Economy, Tucker, R. P. and J. F. Richards (eds.). Duke University Press, Durham, North Carolina.

\subsubsection{South and Southeast Asia}

Bhattacharjee. 1958. Studies in Indian Agricultural Economics. Indian Society of Agricultural Economics, Bombay, India.

Brown, S., A. J. R. Gillespie, and A. E. Lugo. 1991. Biomass of tropical forests of South and Southeast Asia. Canadian Journal of Forest Research 21:111-117.

Cunningham, R. K. 1963. The effect of clearing a tropical forest soil. Journal of Soil Science 14:334-345.

Detwiler, R. P. 1986. Land use change and the global carbon cycle: The role of tropical soils. Biogeochemistry 2:67-93.

FAO. 1961. Timber Trends and Prospects in the Asia-Pacific Region. FAO, Rome. 
FAO. 1981. Forest Resources of Tropical Asia. 2 parts, Tropical Forest Resources Assessment Project (in the framework of the Global Environmental Monitoring System), FAO and United Nations Environment Programme, Rome.

Gajaseni, J. and C. F. Jordan. 1990. Decline of teak yield in northern Thailand: Effects of selective logging on forest structure. Biotropica $22: 114-118$.

Hatch, T., and C. P. Lim. 1979. Shifting cultivation in Sarawak. Department of Agriculture, Kuching, Sarawak, India.

Hozumi, K., K. Yoda, and T. Kira. 1969. Production ecology of a tropical rainforest in southwestem Cambodia: II. Photosynthetic production in an evergreen seasonal forest. Nature and Life in Southeast Asia 6:57-81.

Kira, T. 1978. Community architecture and organic matter dynamics in tropical lowland rain forests with special reference to Pasoh Forest, West Malaysia. pp. 561-590. In Tropical Trees as Living Systems, Tomlinson, P. B. and M. H. Zimmermann (eds.). Cambridge University Press, Cambridge, England.

Myers, N. 1989. Deforestation Rates in Tropical Forests and Their Climatic Implications. Friends of the Earth, London.

Myers, N. 1991. Tropical forests: Present status and future outlook. Climatic Change 19:3-32.

Ogawa, H., K. Yoda, T. Kira, K. Ogino, T. Shidei, D. Ratanawongse, and C. Apasutaya. 1965. Comparative ecological studies on three main types of forest vegetation in Thailan: I. Structure and floristic composition. Nature and Life in Southeast Asia 4:13-48.

Palm, C. A., R. A. Houghton, J. M. Melillo, and D. L. Skole. 1986. Atmospheric carbon dioxide from deforestation in Southeast Asia. Biotropica 18:177-188.

Richards, J. A. and E. P. Flint. 1994. Historic Land Use and Carbon Estimates for South and Southeast Asia: 1880-1980. ORNL/CDIAC-61, NDP-046, Oak Ridge National Laboratory, Oak Ridge, Tennessee.

Sabhasri, S. 1978. Effects of forest fallow cultivation on production and soil. pp. 160-184. In Farmers in the Forest: Economic Development and Marginal Agriculture in Northern Thailand, Kunstadter, P., E. C. Chapman, and S. Sabhasri (eds.). University Press of Hawaii, Honolulu.

Spencer, J. E. 1966. Shifting Cultivation in Southeastern Asia. Vol. 19, University of Califomia Publications in Geography, Berkeley, California.

Woods, P. 1989. Effects of logging, drought, and fire on structure and composition of tropical forests in Sabah, Malaysia. Biotropica 21:290-298. 
Yoda, K. and T. Kira. 1969. Comparative ecological studies on three main types of forest vegetation in Thailand: V. Accumulation and turnover of soil organic matter. Nature Life Southeast Asia 6:57-81.

Zinke, P. J., S. Sabhasri, and P. Kunstadter. 1978. Soil fertility of the Lua forest fallow system of shifting cultivation. pp. 134-159. In Farmers in the Forest: Economic Development and Marginal Agriculture in Northern Thailand, Kunstadter, P., E. Chapman, and S. Sabhasri (eds.). University Press of Hawaii, Honolulu.

\subsubsection{Pacific Developed Region}

FAO. 1981. Forest Resources of Tropical Asia: Country Briefs. Part 2, Tropical Forest Resources Assessment Project (in the framework of the Global Environmental Monitoring System), FAO and United Nations Environment Programme, Rome.

Gifford, R. M. 1992. pp. 151-187. In Australia's Renewable Resources: Sustainability and Global Change. Division of Plant Industry, Commonwealth Scientific and Industrial Research Organization, Canberra, Australia. 
PART 2: INFORMATION ABOUT THE COMPUTERIZED DATA FILES 



\section{CONTENTS OF THE COMPUTERIZED DATA FILES}

The following table lists the 27 files included in this database and distributed by the Carbon Dioxide Information Analysis Center (CDIAC) along with this documentation. These files are available on 9-track magnetic tape, $8-\mathrm{mm}$ tape, $0.25^{\prime \prime}$ tape cartridge, IBM-formatted floppy diskettes, and through the Intemet using the file transfer protocol (FTP) from CDIAC's anonymous FTP server.

Table 4. List and description of the digital files

\begin{tabular}{llll}
$\begin{array}{l}\text { File } \\
\text { number }\end{array}$ & $\begin{array}{l}\text { Name, } \\
\text { type, and description }\end{array}$ & $\begin{array}{l}\text { Logical } \\
\text { records }\end{array}$ & $\begin{array}{l}\text { Record Block File size } \\
\text { length size }\end{array}$ \\
\hline
\end{tabular}

1. NDP-050.DOC

(ASCII)

General descriptive information file that contains the information contained in Part 2 of the documentation.

$80 \quad 8000 \quad 70640$

2. AREAS.FOR

(ASCII)

FORTRAN retrieval program to read and print file 4.

$80 \quad 8000 \quad 2880$

3. AREAS.SAS

$S A S^{\mathrm{TM}}$ retrieval program to read and print file 4.

$80 \quad 8000 \quad 1280$

4. AREAS.ASC

(ASCII)

Land area data for 1700 (most regions), 1850 , and 1980 for the nine regions used

in this data package.

5. AREAS.WK1

(Binary)

Lotus $1-2-3^{\mathrm{TM}}$ file with land area data

for 1700 (most regions), 1850, and 1980 for the nine regions used in this data package.

6. NETFLUX.FOR

FORTRAN retrieval program to read and print file 8 .

7. NETFLUX.SAS

$S_{A S}{ }^{T M}$ retrieval program to read and print file 8. 
Table 4. (continued)

\begin{tabular}{llll}
$\begin{array}{l}\text { File } \\
\text { number }\end{array}$ & $\begin{array}{l}\text { Name, } \\
\text { type, and description }\end{array}$ & $\begin{array}{l}\text { Logical } \\
\text { records }\end{array}$ & $\begin{array}{l}\text { Record Block File size } \\
\text { length size }\end{array}$ \\
\hline
\end{tabular}

8. NETFLUX.ASC (ASCII)

Net carbon emissions to the atmosphere

from 1850 to 1980 for the nine regions

$\begin{array}{lllll}\text { used in this data package. } & 141 & 132 & 6600 & 18612\end{array}$

9. NETFLUX.WK1 (Binary)

Lotus $1-2-3^{\mathrm{TM}}$ file with net carbon

emissions to the atmosphere from 1850

to 1980 for the nine regions used in

this data package.

$100 \quad 1000 \quad 29700$

Lotus $1-2-3^{\mathrm{TM}}$ files with annual land cover change rates for each region

10. ASIA-RAT.WK1 (Binary)

South and Southeast Asia

106

$100 \quad 1000 \quad 10600$

11. CHIIN-RAT.WK1

(Binary)

China

54

$100 \quad 1000 \quad 5400$

12 EURO-RAT.WK1 (Binary)

Europe

55

$100 \quad 1000 \quad 5500$

13. FSU-RAT.WK1

(Binary)

Former Soviet Union

57

$100 \quad 1000 \quad 5700$

14. NAFM-RAT.WK1 (Binary)

North Africa-Middle East

48

$100 \quad 1000 \quad 4800$

15. NAM-RAT.WK1 (Binary)

North America

109

$100 \quad 1000 \quad 10900$

16. PCDV-RAT.WK1 (Binary)

Pacific Developed Region

53

$100 \quad 1000 \quad 5300$

17. SCAM-RAT.WK1 (Binary)

South and Central America

107

$100 \quad 1000 \quad 10700$

18. TAF-RAT.WK1

(Binary)

Tropical Africa

35

$100 \quad 1000 \quad 3500$ 
Table 4. (continued)

File Name,

number

type, and description

Logical

Record Block File size

records

length size

(bytes)

Lotus $1-2-3^{\mathrm{TM}}$ files with the vegetation response curves for each region

19. ASIA-RE.WK1

(Binary)

South and Southeast Asia

53

$100 \quad 1000 \quad 5300$

20. ASIA-SH.WK1 (Binary)

Shifting cultivation response curves

for South and Southeast Asia

$\begin{array}{llll}45 & 100 & 1000 & 4500\end{array}$

21 FSU-RE.WK1 (Binary)

Former Soviet Union

64

$100 \quad 1000 \quad 6400$

22. SCAM-RE.WK1 (Binary)

South and Central America

$100 \quad 1000 \quad 13500$

23. TAF-RE.WK1

(Binary)

Tropical Africa

39

$100 \quad 1000 \quad 3900$

24. TEM-RE.WK1

China, Europe, North Africa-

Middle East, North America,

and the Pacific Developed Region

88

$100 \quad 1000 \quad 8800$

Lotus $1-2-3^{\mathrm{TM}}$ files with carbon partition data. Files are provided only for the six regions whose decay pool partitioning, in the response curves, changes over time.

25. FSULOGPT.WK1 (Binary)

Former Soviet Union

46

$100 \quad 1000 \quad 4600$

26. TEMLOGPT.WK1 (Binary)

China, Europe, North Africa-

Middle East, North America,

and the Pacific Developed Region

49

$100 \quad 1000 \quad 4900$ 
Table 4. (continued)

\begin{tabular}{llll}
$\begin{array}{l}\text { File } \\
\text { number }\end{array}$ & $\begin{array}{l}\text { Name, } \\
\text { type, and description }\end{array}$ & $\begin{array}{l}\text { Logical } \\
\text { records }\end{array}$ & $\begin{array}{l}\text { Record Block } \\
\text { length size size }\end{array}$ \\
\hline
\end{tabular}

Lotus $1-2-3^{\mathrm{TM}}$ file with the equations described in Part 1 of this documentation implemented for one ecosystem in Tropical Africa.

27. MODEL-EX.WK1 (Binary)

Model for the closed forest ecosystem in Tropical Africa.

$1805 \quad 100 \quad 1000 \quad 180500$

$\begin{array}{llll}\text { Total Records } & 4495 & \text { Total Size } & 433272\end{array}$

1. All files are stored in a fixed-block record format.

2. $\quad$ SAS ${ }^{\mathrm{TM}}$ is a registered trademark of the SAS Institute, Inc., Cary, North Carolina 275118000 .

3. Lotus $1-2-3^{\mathrm{TM}}$ is a registered trademark of Lotus Development Corp., 55 Cambridge Parkway, Cambridge, Massachusetts 02142. 


\section{DESCRIPTIVE FILE ON THE MAGNETIC MEDIA}

The following is a listing of the first file provided on the magnetic media distributed by CDIAC. This file provides variable descriptions, formats, units, and other pertinent information about each file associated with this database.

\section{Title Of The Database}

Continental Scale Estimates of the Biotic Carbon Flux from Land Cover Change: 1850 to 1980

\section{Contributors}

Richard A. Houghton

The Woods Hole Research Center

P.O. Box 296

Woods Hole, Massachusetts 02543

U.S.A.

Joseph L. Hackler

The Woods Hole Research Center

P.O. Box 296

Woods Hole, Massachusetts 02543

U.S.A.

\section{Scope Of The Data}

The land cover, response curve, and carbon flux data contained within this database were initially intended to be used by climate modelers as inputs to general circulation models. However, these data may also be used by historians in regional and global scale studies of land cover change, or by any researcher interested in the interrelationships between anthropogenic activities and land cover change, land degradation, or atmospheric carbon concentrations.

This database contains annual estimates of the rate of land cover change for up to 18 different natural ecosystems in nine regions of the world (i.e., North America, Europe, Former Soviet Union, Pacific Developed Region, China, South and Central America, North Africa-Middle East, Tropical Africa, and South and Southeast Asia). Each ecosystem that occurs within a region has a regional and ecosystem specific vegetation-soil response curve. A bookkeeping model was designed that utilized the land cover change rates and the vegetation-soil response curves to calculate the net flux of carbon to and from the atmosphere in each region. These estimates of carbon flux and the land cover change rates have been estimated for the period 1850 to 1980 , with some regions having land cover records beginning in 1700 and carton flux estimates ending in 1990.

Twenty-seven digital files are distributed with this database. Files are included for each region and contain: (1) initial and intermediate land areas for each ecosystem-land cover type (in AREAS.WK1), (2) land cover change rates, (3) vegetation-soil response curves, (4) logging partitioning tables for regions whose logging methods have changed significantly over the last 
century, and (5) annual carbon flux values (in NETFLUX.WK1). The last file included with this database (MODEL-EX.WK1) implements the equations described in Part 1 of this documentation for one ecosystem in Tropical Africa.

Figure 5 provides a schematic that may be used to determine which files were used for calculating the annual carbon flux values for a given region. For example, data from files TAFRAT.WK1 and TAF-RE.WK1 were used in MODEL-EX.WK1 to calculated the carbon flux for one ecosystem in Tropical Africa. The abbreviations used in Figure 5 and in all the filenames used in this database are NAM=North America, EURO=Europe, FSU=Former Soviet Union, PCDV=Pacific Developed, CHIN=China, SCAM=South and Central America, NAFM=North Africa-Middle East, TAF=Tropical Africa, and ASIA=South and Southeast Asia.

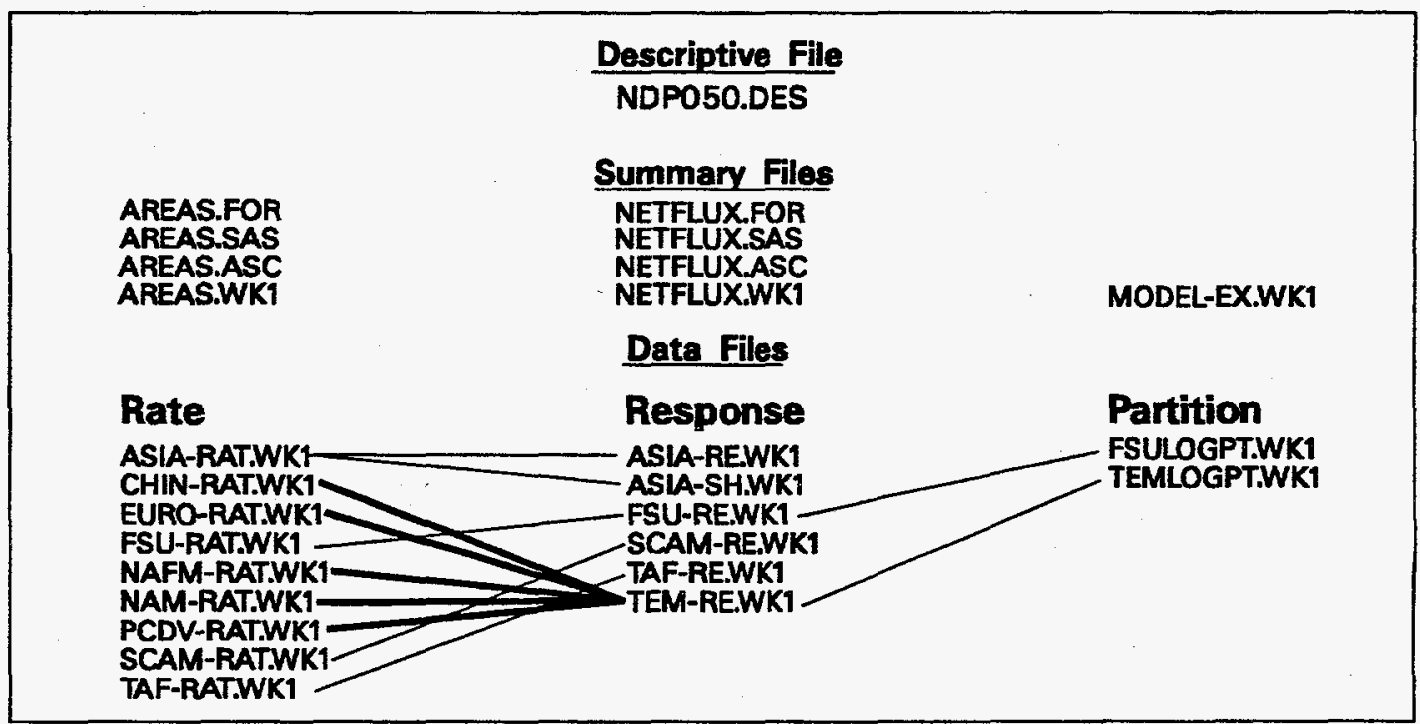

Figure 5. Diagram showing the file combinations used in calculating land cover change and carbon flux in each region (NAM=North America, EURO=Europe, FSU=Former Soviet Union, PCDV=Pacific Developed, CHIN=China, SCAM=South and Central America, NAFM=North Africa-Middle East, TAF=Tropical Africa, and ASIA=South and Southeast Asia). 


\section{Data Formats}

The data within this NDP were initially received as Lotus $1-2-3^{\mathrm{TM}}$ WK1 or WK3 spreadsheets. The Lotus $1-2-3^{\mathrm{TM}}$ spreadsheets have been standardized into the WK1 file format, and data from two summary spreadsheets have been exported into flat ASCII data files to allow their use by a wider audience.

This NDP consists of 1 flat ASCII documentation file, 2 flat ASCII data files, 2 SAS ${ }^{\mathrm{TM}}$ programs, 2 FORTRAN programs, and 20 Lotus 1-2-3 ${ }^{\mathrm{TM}}$ data files; for a total of 27 digital files. The flat ASCII documentation file contains most of the information contained in Part 2 of this document, with postscript graphics and special control characters or symbols removed. The two flat ASCII data Files contain exported versions of the AREAS.WK1 and NETFLUX.WK1 summary spreadsheets. The SAS ${ }^{\text {TM }}$ and FORTRAN files are in a ASCII format and contain programs to read the flat ASCII data files. The 20 Lotus $1-2-3^{\mathrm{TM}}$ files contain the land cover change rates ( 9 files), vegetation-soil response curves ( 6 files), decay pool partitioning tables ( 2 files), initial and ending land cover areas ( 1 file), annual carbon flux by region (1 file), and a simplified bookkeeping model (1 file) customized for Tropical Africa.

All land cover change values in the spreadsheets are expressed in units of $10^{6}$ ha. The vegetation-soil response curves are calibrated for 1 ha of land and have values in megagrams of Carbon (1 Mg of carbon = 1 metric ton of carbon). The carbon flux values for each region were obtained using the carbon flux equations shown in Part 1 of this document and are based on the land cover change and response curve data. The calculated carbon flux values are expressed in $10^{6}$ $\mathrm{Mg}$ of $\mathrm{C}$.

\section{Flat ASCII Data Files}

Two flat ASCII data files (i.e., AREAS.ASC and NETFLUX.ASC) are provided with this data package along with two SAS ${ }^{\mathrm{TM}}$ and two FORTRAN programs designed to read and print the contents of each data file. The information within these files allows the user to ascertain the total amount of land in each ecosystem in 1700 (for most regions), 1850, and 1980, and to determine the annual regional and global carbon flux from vegetation and soils due to land cover change.

The following pages contain a description of the contents and formats of the two flat ASCII data files distributed with this NDP.

Lotus $1-2-3^{\mathrm{TM}}$ is a registered trademark of Lotus Development Corporation, Cambridge, Massachusetts 02142.

$\mathrm{SAS}^{\mathrm{TM}}$ is a registered trademark of the SAS Institute, Inc., Cary, North Carolina 27511-8000. 
File: AREAS.ASC

The name of the first flat ASCII data file is AREAS.ASC. The FORTRAN and SAS ${ }^{\mathrm{TM}}$ programs provided to read this data file are named AREAS.FOR and AREAS.SAS, respectively. A summary of the FORTRAN statements used to read the data file follows:

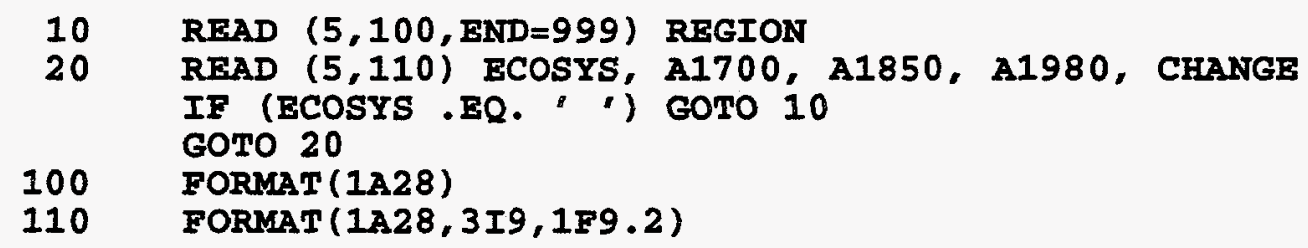

The variables in AREAS.ASC, listed below, are shown in the same order as they appear in the data file.

Table 5. Variable formats for AREAS.ASC

\begin{tabular}{|c|c|c|c|c|c|}
\hline $\begin{array}{l}\text { Variable } \\
\text { name }\end{array}$ & $\begin{array}{l}\text { Variable } \\
\text { type }\end{array}$ & $\begin{array}{l}\text { Variable } \\
\text { width }\end{array}$ & \multicolumn{2}{|c|}{ Column } & $\begin{array}{l}\text { Variable } \\
\text { description }\end{array}$ \\
\hline REGION & Character & 28 & 1 & 28 & Region name \\
\hline \multicolumn{6}{|c|}{---SECOND LINE, Repeated until all ecosystems are read--- } \\
\hline ECOSYS & Character & 28 & 1 & 28 & Ecosystem name \\
\hline A1700 & Integer & 9 & 29 & 37 & $\begin{array}{l}\text { Land in ECOSYS in } \\
\text { the year } 1700 \text {; values } \\
\text { are in } 10^{6} \mathrm{ha}\end{array}$ \\
\hline A1850 & Integer & 9 & 38 & 46 & $\begin{array}{l}\text { Land in ECOSYS in } \\
\text { the year } 1850 \text {; values } \\
\text { are in } 10^{6} \mathrm{ha}\end{array}$ \\
\hline A1980 & Integer & 9 & 47 & 55 & $\begin{array}{l}\text { Land in ECOSYS in } \\
\text { the year } 1980 \text {; values } \\
\text { are in } 10^{6} \text { ha }\end{array}$ \\
\hline CHANGE & Real & 9 & 56 & 64 & $\begin{array}{l}\text { Percent change in the land } \\
\text { area in ECOSYS from } \\
1850 \text { to } 1980\end{array}$ \\
\hline
\end{tabular}


Missing data values in this file are indicated with the value -9999.00 .

File: NETFLUX.ASC

The name of the second flat ASCII data file is NETFLUX.ASC. The FORTRAN and SAS ${ }^{\mathrm{TM}}$ programs provided to read this data file are named NETFLUX.FOR and NETFLUX.SAS, respectively. A summary of the FORTRAN statements used to read the data file follows:

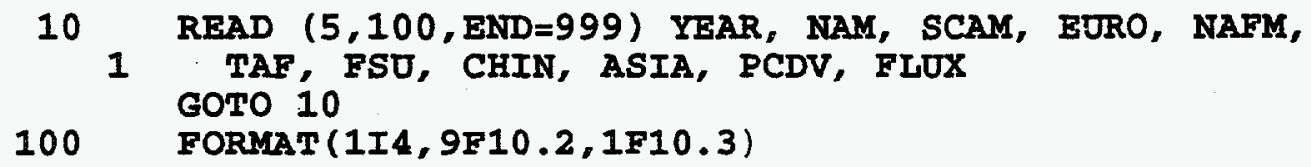

The variables in NETFLUX.ASC, listed below, are shown in the same order as they appear in the data file.

Table 6. Variable formats for NETFLUX.ASC

\begin{tabular}{|c|c|c|c|c|c|}
\hline $\begin{array}{l}\text { Variable } \\
\text { name }\end{array}$ & $\begin{array}{l}\text { Variable } \\
\text { type }\end{array}$ & $\begin{array}{l}\text { Variable } \\
\text { width }\end{array}$ & $\frac{\text { Col }}{\text { Start }}$ & $\frac{\mathrm{nn}}{\mathrm{End}}$ & $\begin{array}{l}\text { Variable } \\
\text { description }\end{array}$ \\
\hline YEAR & Integer & 4 & 1 & 4 & $\begin{array}{l}\text { Year for which the flux } \\
\text { data was calculated }\end{array}$ \\
\hline NAM & Real & 10 & 5 & 14 & $\begin{array}{l}\text { Carbon flux in YEAR } \\
\text { from land cover change } \\
\text { in North America; } \\
\text { values are in } 10^{6} \mathrm{Mg} \mathrm{C}\end{array}$ \\
\hline SCAM & Real & 10 & 15 & 24 & $\begin{array}{l}\text { Carbon flux in YEAR } \\
\text { from land cover change } \\
\text { in South and Central } \\
\text { America; values are in } 10^{6} \\
\text { Mg C }\end{array}$ \\
\hline EURO & Real & 10 & 25 & 34 & $\begin{array}{l}\text { Carbon flux in YEAR } \\
\text { from land cover change } \\
\text { in Europe; values are in } \\
10^{6} \mathrm{Mg} \mathrm{C}\end{array}$ \\
\hline
\end{tabular}


Table 6. (continued)

\begin{tabular}{|c|c|c|c|c|c|}
\hline $\begin{array}{l}\text { Variable } \\
\text { name }\end{array}$ & $\begin{array}{l}\text { Variable } \\
\text { type }\end{array}$ & $\begin{array}{l}\text { Variable } \\
\text { width }\end{array}$ & $\frac{\text { Coll }}{\text { Start }}$ & $\frac{\mathrm{nn}}{\text { End }}$ & $\begin{array}{l}\text { Variable } \\
\text { description }\end{array}$ \\
\hline NAFM & Real & 10 & 35 & 44 & $\begin{array}{l}\text { Carbon flux in YEAR } \\
\text { from land cover change } \\
\text { in North Africa-Middle } \\
\text { East; values are in } 10^{6} \\
\text { Mg C }\end{array}$ \\
\hline TAF & Real & 10 & 45 & 54 & $\begin{array}{l}\text { Carbon flux in YEAR } \\
\text { from land cover change } \\
\text { in Tropical Africa; values } \\
\text { are in } 10^{6} \mathrm{Mg} \mathrm{C}\end{array}$ \\
\hline FSU & Real & 10 & 55 & 64 & $\begin{array}{l}\text { Carbon flux in YEAR } \\
\text { from land cover change } \\
\text { in the Former Soviet } \\
\text { Union; values are in } \\
10^{6} \mathrm{Mg} \mathrm{C}\end{array}$ \\
\hline $\mathrm{CHIN}$ & Real & 10 & 65 & 74 & $\begin{array}{l}\text { Carbon flux in YEAR } \\
\text { from land cover change } \\
\text { in China; values are in } \\
10^{6} \mathrm{Mg} \mathrm{C}\end{array}$ \\
\hline ASIA & Real & 10 & 75 & 84 & $\begin{array}{l}\text { Carbon flux in YEAR } \\
\text { from land cover change } \\
\text { in South and Southeast } \\
\text { Asia; values are in } \\
10^{6} \mathrm{Mg} \mathrm{C}\end{array}$ \\
\hline PCDV & Real & 10 & 85 & 94 & $\begin{array}{l}\text { Carbon flux in YEAR } \\
\text { from land cover change } \\
\text { in the Pacific Developed } \\
\text { Region; values are in } \\
10^{6} \mathrm{Mg} \mathrm{C}\end{array}$ \\
\hline FLUX & Real & 10 & 95 & 104 & $\begin{array}{l}\text { Total carbon flux in } \\
\text { YEAR from land cover } \\
\text { change in the world; } \\
\text { values are in } 10^{6} \mathrm{Mg} \mathrm{C}\end{array}$ \\
\hline
\end{tabular}

Missing data values in this file are indicated with the value -9999.00 . 


\section{Lotus 1-2-3 ${ }^{\mathrm{TM}}$ WK1 Spreadsheet Files}

Twenty Lotus 1-2-3 ${ }^{\mathrm{TM}}$ WK1 spreadsheet files are provided with this NDP. The first two files (AREAS.WK1 and NETFLUX.WK1) contain the same data contained in the ASCII files AREAS.ASC and NETFLUX.ASC. Seventeen of the remaining 18 spreadsheets contain the data used in the carbon flux model to calculate the annual net flux of carbon to or from the atmosphere for each region. The 18th file (MODEL-EX.WK1) is an implementation of the simplified carbon flux equations given in Part 1 of this documentation for one ecosystem in Tropical Africa.

\section{Rate Files:}

The land cover change rate data for each region are contained in nine spreadsheets (ASIA-RAT.WK1, CHIN-RAT.WK1 EURO-RAT.WK1, FSU-RAT.WK1, NAFM-RAT.WK1, NAM-RAT.WK1, PCDV-RAT.WK1, SCAM-RAT.WK1, and TAF-RAT.WK1). Historical land cover data were collected at the global, regional, and country level and used to derive rates of land cover change for natural ecosystems in each region of the world. These regions cover most of the vegetated land on Earth, with only small, undeveloped islands and large unvegetated regions excluded from the database (e.g., Antarctica and Greenland).

Geographic location and data availability determined the name and number of ecosystems contained within a region. Data were collected on, and divided among, the natural ecosystems occurring in each region. Each rate spreadsheet contains data for one region, with individual land cover change rates provided for each ecosystem and clearing method. Each ecosystem may have up to seven types of conversion curves: (1) clearing for cropland, (2) clearing for pasture, (3) industrial logging, (4) nonindustrial logging, (5) shifting cultivation, (6) degradation, and (7) afforestation. In most cases, however, only two or three conversion curves are needed for a given ecosystem within a region. Because the number of ecosystems and number of clearing curves vary by region, the format of the spreadsheets differ slightly. However, each region file contains the same data variables for each ecosystem.

The following table depicts a portion of the Lotus $1-2-3^{T M}$ land cover change rate file (from PCDV-RAT.WK1) for a portion of the Pacific Developed Region. The variable location and definitions identified in this example are consistent within all nine rate spreadsheets. The file contains data for "rates of land cover change" for the Pacific Developed Region. This portion of the file contains the rates of change for "Clearing for Cropland". The rates of change are shown for four time periods, three ecosystems, and are in $10^{6}$ ha per year. The numeral to the left, and just below the first time period (year range) indicates the method used to extrapolate between the clearing rates.

In this case the "method" value of 1 indicates that a stepwise function was used for the conversion of the natural ecosystems to cropland, while a value of 2 would indicated that a linear equation was developed that viewed the rates as points on a line. For example, this table shows that $0.001 \times 10^{6}$ ha of Tropical Moist Forest were cleared from 1700 to 1869 and in 1870 this rate increased to $0.038 \times 10^{6}$ ha. If the method value had been equal to 2 , then 0 ha would have been the initial clearing rate for 1700 and the amount of land cleared would have increased by a constant amount until $0.001 \times 10^{6}$ ha was reached in 1869 . 
PCDV-RAT.WK1

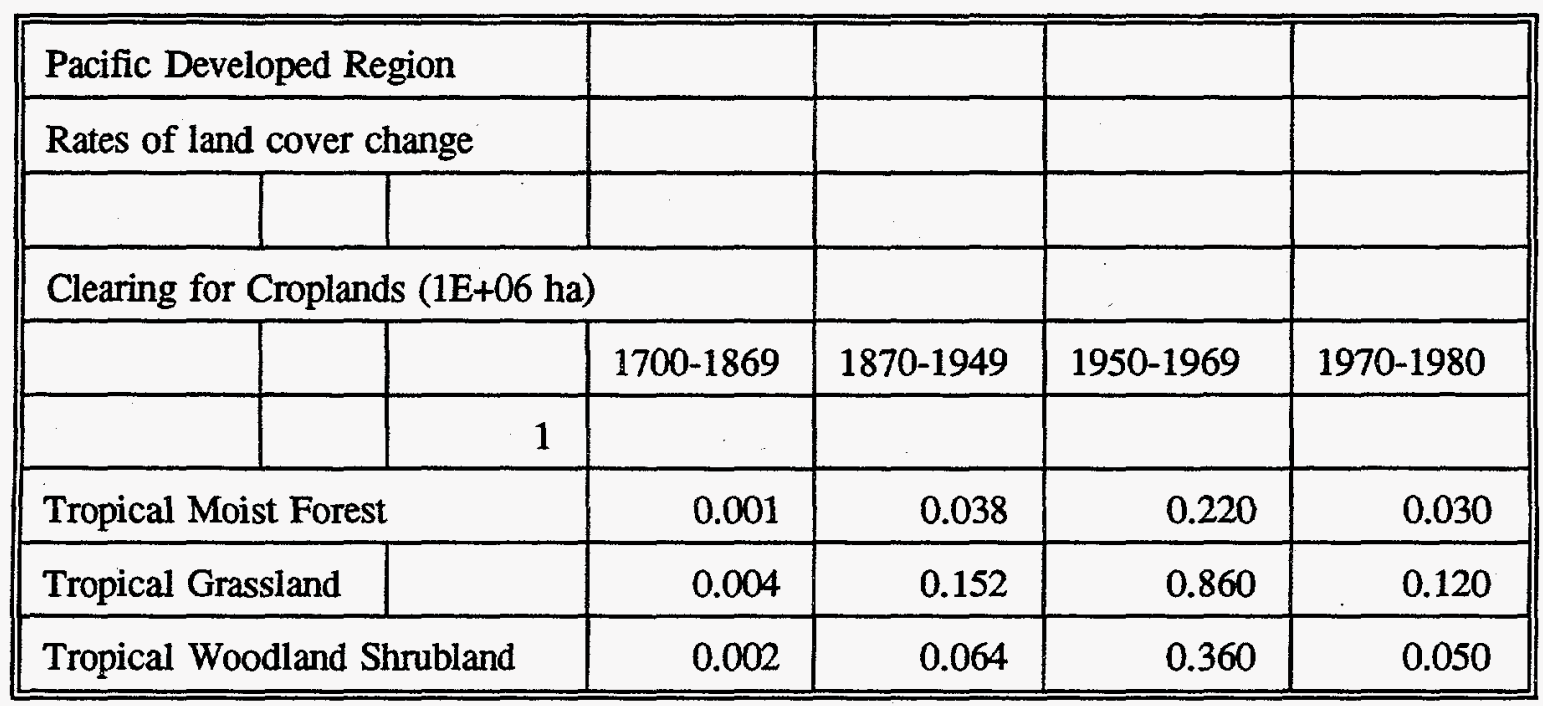

\section{Response Files:}

The response to disturbance data are contained in six Lotus 1-2-3 ${ }^{\mathrm{TM}}$ files (ASIA-RE.WK1, ASIA-SH.WK1, FSU-RE.WK1, SCAM-RE.WK1, TAF-RE.WK1, and TEM-RE.WK1). File TEMRE.WK1 contains the response curves used for five regions (China, Europe, North Africa-Middle East, North America, and Pacific Developed Region). Each ecosystem within a region has a corresponding response curve that contains information on the initial carbon content (per hectare) of vegetation and soil. These values were first computed as dry matter and then multiplied by 0.45 to obtain the carbon values shown in the response curves. In this study, estimates of the organic carbon were made for the top $1 \mathrm{~m}$ of soil. The data contained in these response curves includes information on the minimum carbon content reached after clearing, time (in years) to reach this minimum, carbon in live vegetation (e.g., crops) left on site, time for carbon levels to recover after abandonment, time for recovered area to reach initial carbon levels, and the fraction of cleared vegetation assigned to decay pools (i.e., the carbon in harvested vegetation decays at different rates based on the use to which the vegetation is put).

In the carbon flux model five different decay pools were used, the first contained slash, dead vegetation left on-site at the time of clearing. Biomass in this pool is released to the atmosphere based on an ecosystem and region specific on-site decay rate. The second is the 1-year decay pool. Biomass assigned to this pool is assumed to be bumed and is released to the atmosphere in the year following clearing. The third, fourth, and fifth pools are the 10-year, 100-year, and 1000-year decay pools. 


\begin{tabular}{|c|c|c|c|}
\hline \multicolumn{3}{|c|}{ North America, China, Europe, Pacific Developed Region, North Africa-Middle East } & \\
\hline Response Curve - Clearing & & & \\
\hline \multicolumn{4}{|c|}{ Changes in the carbon in vegetation and soils during the clearing of natural ecosystems. } \\
\hline & $\begin{array}{l}\text { Ecosystem } \\
-\rightarrow>\end{array}$ & 1 & 2 \\
\hline & & Tropical & Tropical \\
\hline & & Moist & Seasonal \\
\hline Carbon in vegetation of undisturbed ecosystem $\left(10^{\wedge} 6 \mathrm{~g} / \mathrm{ha}\right)$ & & 200 & 160 \\
\hline Carbon in vegetation of "recovered" ecosystem $\left(10^{\wedge} 6 \mathrm{~g} / \mathrm{ha}\right)$ & & 150 & 120 \\
\hline Carbon in Crops & & 5 & 5 \\
\hline Time for abandoned system to "recover" (yr) & & 50 & 50 \\
\hline Time for veg. to recover to primary state from "recovered" & & 1 & 1 \\
\hline Carbon in soils of undisturbed ecosystems & & 117 & 117 \\
\hline Carbon in soils of "recovered" ecosystems & & 103 & 103 \\
\hline Carbon content of soil after initial rapid change following clearing & & 94 & 94 \\
\hline Minimum carbon content of soil in cultivated system & & 88 & 88 \\
\hline Time initial rapid change & & 3 & 3 \\
\hline Time to soil minimum & & 15 & 15 \\
\hline Time for soil to "recovered" & & 15 & 15 \\
\hline Time for soil to recover to primary state from "recovered" & & 1 & 1 \\
\hline \multicolumn{4}{|l|}{$\begin{array}{l}\text { Fraction of original veg. assigned to decay pools at time of } \\
\text { clearing }\end{array}$} \\
\hline $1-\mathrm{yr}$ & & 0.4 & 0.4 \\
\hline $10-y r$ & & 0.27 & 0.27 \\
\hline $100-\mathrm{yr}$ & & 0 & 0 \\
\hline $1000-y r$ & & 0 & 0 \\
\hline Left to decay on site & & 0.33 & 0.33 \\
\hline Rate constant for on-site decay & & 0.5 & 0.4 \\
\hline
\end{tabular}

The proceeding table depicts the general format of the Lotus 1-2-3 ${ }^{\mathrm{TM}}$ data files for a portion of the response curve file (TEM-RE.WK1) for the Pacific Developed Region. The variable location and definitions identified in this example are consistent within all response spreadsheets. 
Data values contained in these files are expressed in $\mathrm{Mg}$ of carbon per hectare, years, or percentages. For example, in the Pacific Developed Region the initial carbon content of an undisturbed tropical moist forest is $200 \mathrm{Mg} \mathrm{C}$ per ha, after clearing it will take 51 years for the forest to recover to its primary state, and $33 \%$ of the carbon in the cleared forest was left to decay on-site as slash.

\section{Partition Files:}

The logging decay pool partitioning tables are contained in two Lotus $1-2-3^{\mathrm{TM}}$ files (FSULOGPT.WK1 and TEMLOGPT.WK1) and are used in conjunction with the response curve spreadsheets for six of the world's nine regions. File TEMLOGPT.WK1 contains the decay pool partitioning data used for China, Europe, North Africa-Middle East, North America, and Pacific Developed Region, while FSULOGPT.WK1 contains the data for the Former Soviet Union.

These files provide decay pool assignments for the 1-year, 10-year, 100-year, and 1000-year decay rates for industrial and nonindustrial logging. The decay pool distribution varies in these six regions because of the significant technological changes that have occurred over the last 120 years as they made the transition from agricultural to industrial economies.

The decay rate values for each pool are valid for a range of years or are point values that have had linear equations derived to calculate the annual rate for a given pool (similar to stepwise and linear methods used in the rate files). In each file a "method" variable is located under the "Decay Pool" label. A value of 1 indicates that a stepwise function was used for the decay pool rate, while a value of 2 indicates that a linear equation was developed that viewed the rates as points on a line.

\section{Model File:}

Simplified versions of the equations used by the original carbon flux bookkeeping model are contained in Part 1 of this document. These equations produce results that are within $10 \%$ of those obtained by the original model. To provide the user with an example of how these equations would be implemented, file MODEL-EX.WK1 has been included with this NDP. The file implements the carbon flux equation for the closed forest ecosystem in Tropical Africa.

The carbon flux equation, shown below, calculates the annual carbon flux (CF) with the atmosphere for one ecosystem. The carbon flux for each ecosystem would then be aggregated to obtain an annual carbon flux for a region.

$$
\text { CF }=\text { Soil }_{r}+\text { Slash }_{r}+\text { P1 }_{r}+\text { P10 }_{r}+\text { P100 }_{r}+\text { P1000 }_{r}-\left(\text { Crop }_{\mathbf{a}}+\text { Soil }_{\mathbf{a}}+\text { Veg }_{\mathbf{a}}\right)
$$

where Soil is the carbon released from disturbed soil, Slash is the carbon released from dead vegetation left on-site after clearing, $\mathrm{P} 1_{\mathrm{r}}$ through $\mathrm{P} 1000_{\mathrm{r}}$ contain the amount of carbon released from the 1-, 10-, 100-, and 1000-year decay pools, and Crop $\mathrm{a}_{\mathrm{a}}$, Soil ${ }_{\mathrm{a}}$, and $\mathrm{Veg}_{\mathrm{a}}$ are the amount of carbon removed from the atmosphere from the growth of crops and regrowth and recover of soils and vegetation.

The model file distributed with this NDP uses the acronyms in this carbon flux equation (above) to identify each column in the spreadsheet. The model file also includes pertinent data 
from the Tropical Africa land cover change rate and vegetation-soil response curve data files for the closed forest ecosystem. The equations in the column under each acronym contain a detailed equation for each function.

The model file has had the "protect" option in Lotus $1-2-3^{\mathrm{TM}}$ enabled to prevent accidental changes to the carbon flux equations. Three user-modifiable ranges are available to allow the user to input data from any of the ecosystem response spreadsheets and to alter the ecosystem change rates. It should be noted that some of the equations have been customized for Tropical Africa (e.g., the reforestation recovery time is built into the Soil ${ }_{\mathrm{a}}$ and $\mathrm{Veg}_{\mathrm{a}}$ equations). For regions other than Tropical Africa the protect option may be disabled and the equations modified. (Users should review all equations in Part 1 of this document before making modifications to the model.)

What follows is a portion of file MODEL-EX.WK1. The columns for $\mathrm{P} 100_{\mathrm{r}}$ and $\mathrm{P} 1000_{\mathrm{r}}$ are not shown here (but are in the file) because material was not assigned to these decay pools by the Tropical Africa response curve.

\begin{tabular}{|c|c|c|c|c|c|c|c|c|c|c|c|c|c|c|}
\hline & Closed & & Soil & + & Slash & $+\mathrm{P1}$ & + & P10 & $-\quad($ & Crop + & Soil + & Veg ) & $=$ & CF \\
\hline & Forest & & $\mathbf{r}$ & & $\mathbf{r}$ & $\mathbf{r}$ & & $\mathbf{r}$ & & $\mathbf{a}$ & a & $\mathbf{a}$ & & \\
\hline & Land & land & soil & Slash & Slash & forest & forest & forest & Total & Crop & Soil & Veg & Total & flux \\
\hline Year & cleared & $\begin{array}{l}\text { abon- } \\
\text { doned }\end{array}$ & out & pool & out & $\begin{array}{l}1-\mathrm{yr} \\
\text { out }\end{array}$ & $\begin{array}{l}10-y r \\
\text { pool }\end{array}$ & $\begin{array}{l}10-y r \\
\text { out }\end{array}$ & output & in & in & in & inpat & total \\
\hline 1800 & 0.02088 & 0.000 & - & 0.937 & 0.369 & - & 0.767 & 0.077 & 0.445 & 0.313 & 0.000 & 0.000 & 0.313 & 0.132 \\
\hline 1801 & 0.02088 & 0.000 & - & 1.505 & 0.592 & 1.136 & 1.457 & 0.146 & 1.874 & 0.313 & 0.000 & 0.000 & 0.313 & 1.561 \\
\hline 1802 & 0.02088 & 0.000 & - & 1.850 & 0.728 & 1.136 & 2.078 & 0.208 & 2.072 & 0.313 & 0.000 & 0.000 & 0.313 & 1.759 \\
\hline 1803 & 0.02088 & 0.000 & - & 2.059 & 0.810 & 1.136 & 2.637 & 0.264 & 2.210 & 0.313 & 0.000 & 0.000 & 0.313 & 1.897 \\
\hline 1804 & 0.02088 & 0.000 & 0.522 & 2.186 & 0.860 & 1.136 & 3.140 & 0.314 & 2.832 & 0.313 & 0.000 & 0.000 & 0.313 & 2.519 \\
\hline 1805 & 0.02088 & 0.000 & 0.522 & 2.263 & 0.890 & 1.136 & 3.592 & 0.359 & 2.908 & 0.313 & 0.000 & 0.000 & 0.313 & 2.594 \\
\hline 1806 & 0.02088 & 0.000 & 0.522 & 2.310 & 0.909 & 1.136 & 4.000 & 0.400 & 2.967 & 0.313 & 0.000 & 0.000 & 0.313 & 2.654 \\
\hline 1807 & 0.02088 & 0.000 & 0.522 & 2.338 & 0.920 & 1.136 & 4.367 & 0.437 & 3.015 & 0.313 & 0.000 & 0.000 & 0.313 & 2.701 \\
\hline 1808 & 0.02088 & 0.000 & 0.522 & 2.355 & 0.927 & 1.136 & 4.697 & 0.470 & 3.054 & 0.313 & 0.000 & 0.000 & 0.313 & 2.741 \\
\hline 1809 & 0.02088 & 0.000 & 0.522 & 2.366 & 0.931 & 1.136 & 4.994 & 0.499 & 3.088 & 0.313 & 0.000 & 0.000 & 0.313 & 2.775 \\
\hline 1810 & 0.02088 & 0.000 & 0.522 & 2.372 & 0.933 & 1.136 & 5.261 & 0.526 & 3.117 & 0.313 & 0.000 & 0.000 & 0.313 & 2.804 \\
\hline 1811 & 0.02088 & 0.000 & 0.522 & 2.376 & 0.935 & 1.136 & 5.502 & 0.550 & 3.143 & 0.313 & 0.000 & 0.000 & 0.313 & 2.830 \\
\hline
\end{tabular}


The carbon flux equation is primarily designed to model and track the transfer of forested lands to land uses with lower carbon contents (e.g., to pasture from tropical forest). During initial human habitation of a region, only undisturbed high carbon content primary forests are available for clearing. Once the minimum amount of land required for subsistence agriculture is obtained, further forests are cleared to obtain wood products. The primary forests harvested for wood products, unlike those cleared for agriculture, may be allowed to revert back to forest and, with time, will recover to their previous high carbon levels.

In modern agroforestry, trees are planted on previously cleared forestland and are allowed to grow for a few decades. These managed forest have a carbon content very close to that of primary forest when they have reached maturity (i.e., recovered) and are ready to be harvested in 20 to 30 -years and will have the same carbon content as primary forest in 30 to 100-years.

In the bookkeeping carbon model, forestlands that have just recovered in a given year will be cleared before a similar undisturbed primary forest will be cleared. For example, the land cover rate curve for North America shows that $0.905 \times 10^{6}$ ha of temperate evergreen forest were logged in 1969, and the model has determined (based on the North America response curve) that 0.895 $\times 10^{6}$ ha of forest has "just recovered" from being logged in 1919 , thus the $0.895 \times 10^{6}$ ha of recovered forest will be recleared along with $0.01 \times 10^{6}$ ha of primary forest. This distinction is important because the recovered forest contains $25 \%$ less carbon than that of primary forest.

In South and Southeast Asia a differentiation has been made between undisturbed and degraded ecosystems. In this region each forest ecosystem is represented by two pools of land (e.g., degraded moist forest and undisturbed moist forest). Similarly, separate land cover change rates and vegetation-soil response curves are provided. When a given amount of undisturbed forest is degraded (per the land cover change rate file for South and Southeast Asia) it is transferred to the degraded pool. The amount of carbon released is determined by subtracting the amount of "carbon in vegetation of undisturbed ecosystem" for the undisturbed forest from that of the disturbed forest. This carbon is released based on the five decay pool definitions given in the undisturbed forest response curve. (Note that during the conversion from undisturbed to disturbed forest that the "carbon in soils of undisturbed ecosystems" remains unchange.) 


\section{LISTING OF THE FORTRAN AND SAS ${ }^{\mathrm{TM}}$ DATA RETRIEVAL PROGRAMS}

This section lists the two FORTRAN and two SAS ${ }^{\mathrm{TM}}$ data retrieval programs provided by CDIAC to read and write the contents of the flat ASCII data files. The two programs shown below (AREAS.FOR and AREAS.SAS) are designed to read and write the contents of AREAS.ASC.

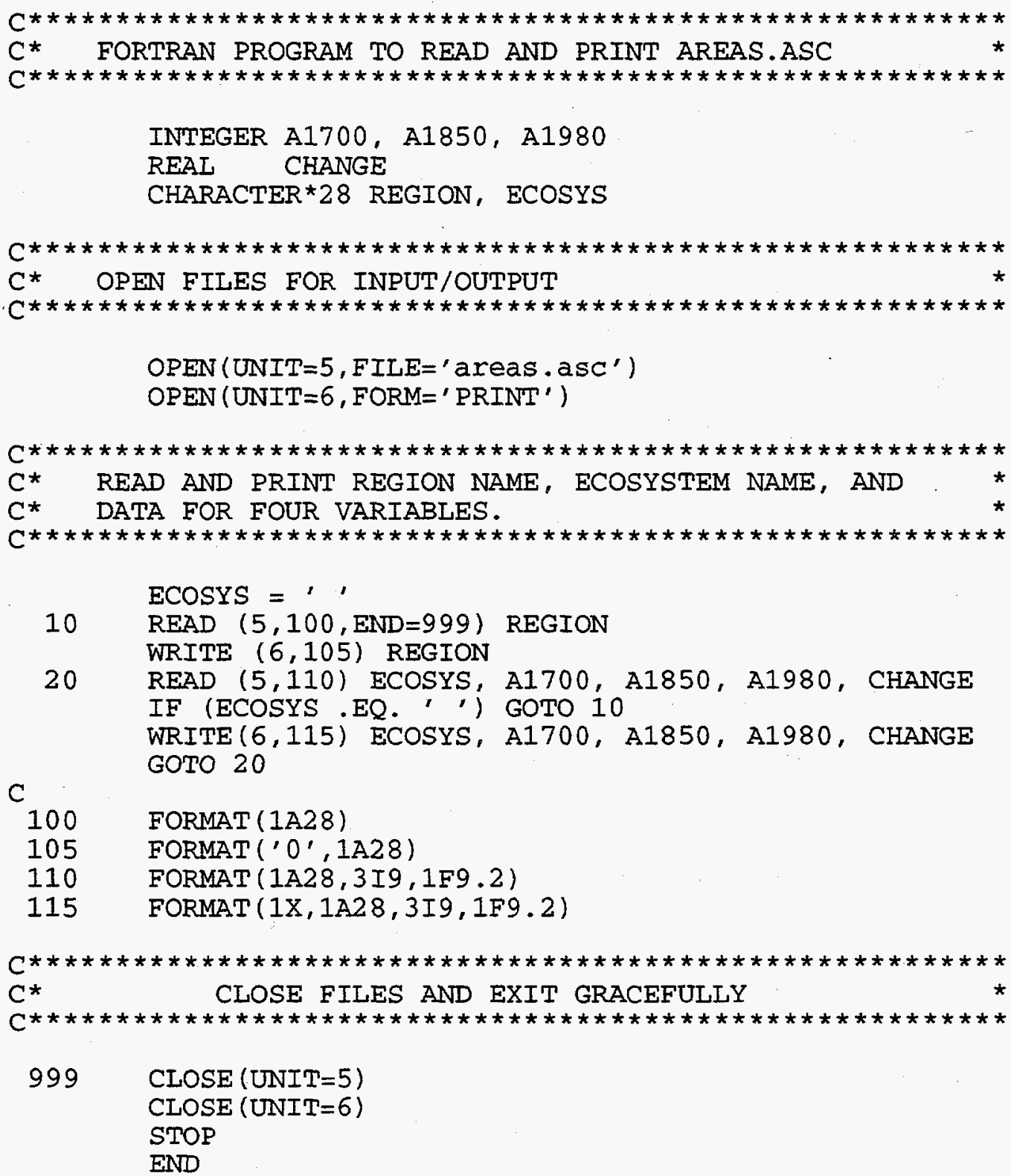


$f *$

This program reads and prints the contents

of file AREAS.ASC

* $/$

OPTIONS LINESIZE $=78$ PAGESIZE $=60$;

DATA IN;

INFILE' / /areas.asc';

INPUT REG \$1-28/ ECOSYS \$ $1-28$;

DO WHILE (ECOSYS NE' ') ;

INPUT A1700 29-37 A1850 38-46 A1980 47-55 CHANGE 56-64;

OUTPUT;

INPUT ECOSYS \$ $1-28$;

END;

DELETE;

PROC PRINT NOOBS;

RUN;

The third and forth programs (NETFLUX.FOR and NETFLUX.SAS) read and write the contents of NETFLUX.ASC.

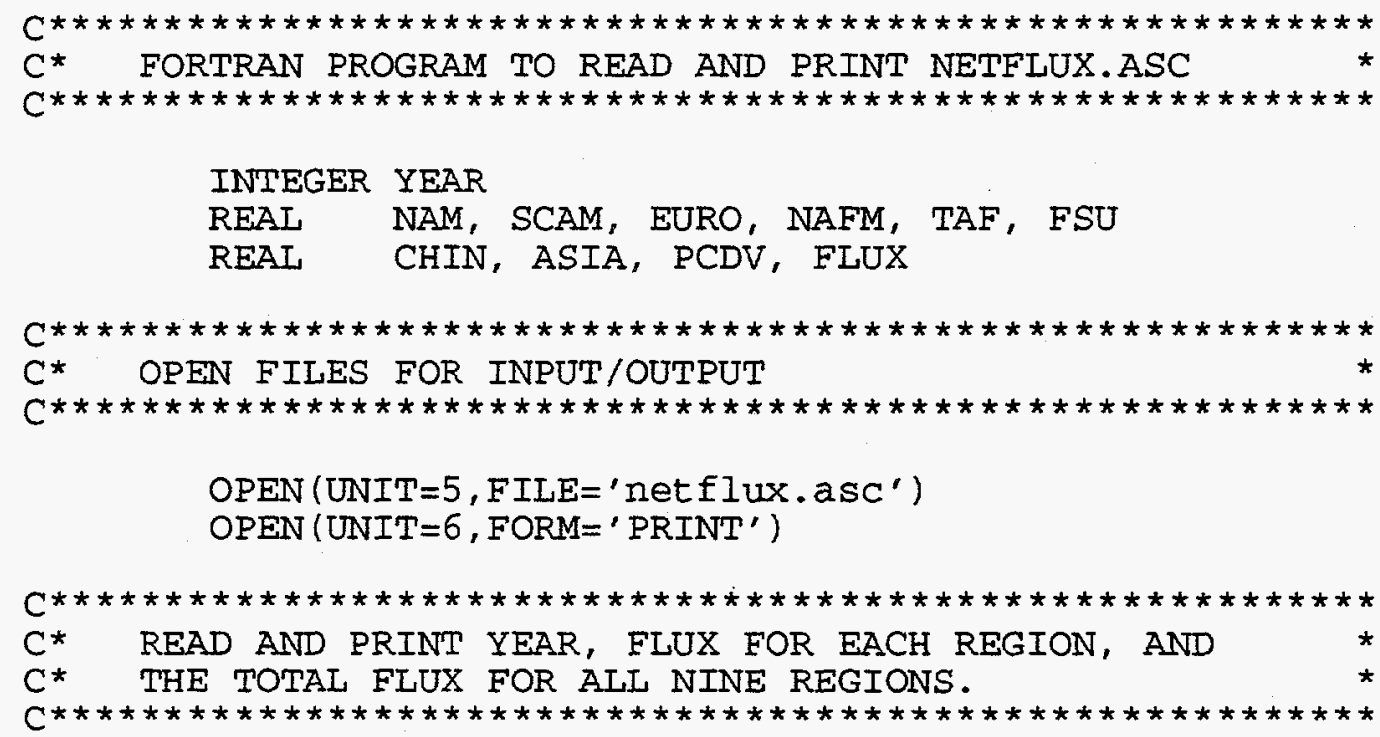

10 READ $(5,100, E N D=999)$ YEAR, NAM, SCAM, EURO, NAFM, 1 TAF, FSU, CHIN, ASIA, PCDV, FLUX

WRITE $(6,105)$ YEAR, NAM, SCAM, EURO, NAFM,

1 TAF, FSU, CHIN, ASIA, PCDV, FLUX GOTO 10

C

$100 \quad$ FORMAT $(1 \mathrm{I} 4,9 \mathrm{~F} 10.2,1 \mathrm{~F} 10.3)$

105 FORMAT $(1 \mathrm{X}, 1 \mathrm{I} 4,9 \mathrm{~F} 10.2,1 \mathrm{~F} 10.3)$

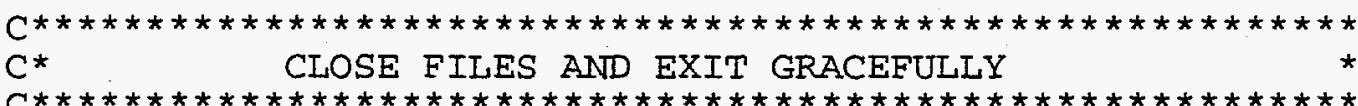

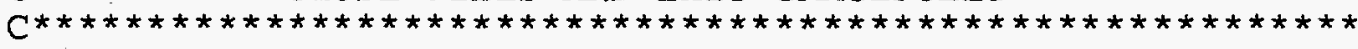

999 CLOSE (UNIT=5) 
CLOSE (UNIT $=6$ )

STOP

END

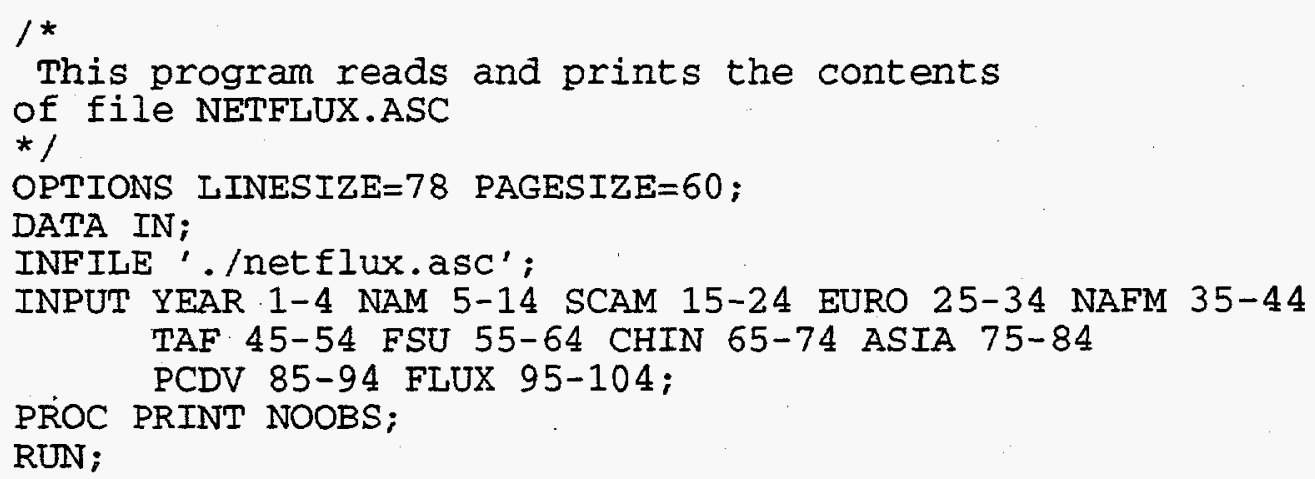

\section{PARTIAL LISTING OF THE FLAT ASCII DATA FILES}

This section lists the first $\mathbf{1 5}$ data lines from the two flat ASCI files provided with this database.

Sample listing from AREAS.ASC

North America

Temperate Evergreen Forest

236

157

Temperate Deciduous Forest

Boreal Forest

Temperate Woodland Shrubland

Temperate Grassland

South and Central America

Tropical Evergreen Forest

Tropical Seasonal Forest

Tropical Open Forest

Temperate Evergreen Forest

Temperate Seasonal Forest

...

Sample listing from NETFLUX.ASC

$\begin{array}{lll}22.17 & 57.04 & 3.95 \\ 21.87 & 57.02 & 3.95 \\ 21.60 & 57.00 & 3.95 \\ 21.35 & 56.98 & 3.95 \\ 21.13 & 56.96 & 3.95 \\ 20.93 & 56.93 & 3.95 \\ 20.76 & 56.91 & 3.95\end{array}$

$-9999$

$-9999$

$-9999$

$-9999$

$-9999$

20.76

56.91

3.95

$-0.04$

$-0.06$

$-0.01$

$-0.04$

$-0.64$

$1.83 \quad 352.081$

$1851 \quad 140.82$

$1.83 \quad 382.670$

$1852 \quad 143.78$

$1.84 \quad 396.939$

$1853 \quad 146.66$

$1.84 \quad 407.887$

$1854 \quad 149.47$

$1.84 \quad 416.611$

$1855 \quad 152.24$

$1.84 \quad 423.852$

$\begin{array}{lr}1856 & 154.99\end{array}$

226

616

380

49

42

217
506
252
40
40

$-0.04$

$-0.18$

$-0.34$

$-0.19$

$-0.04$ 


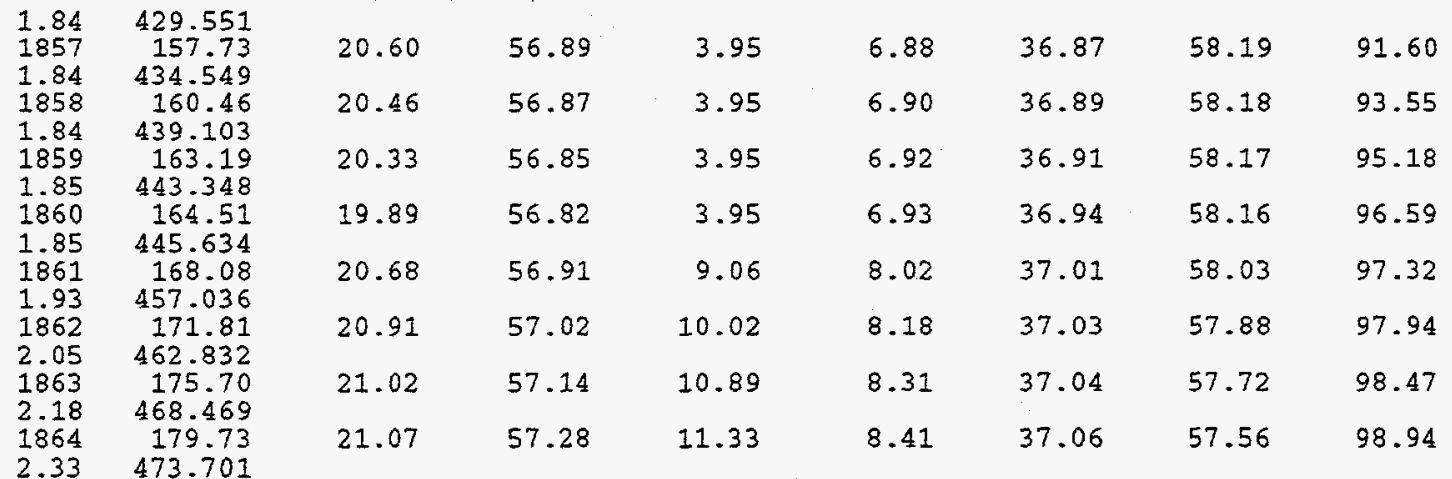

\section{VERIFICATION OF DATA TRANSPORT: FLAT ASCII DATA FILES}

After the data files provided with this NDP are loaded onto a system, or downloaded from CDIAC's anonymous FTP area, the user should check to verified that they have not been corrupted in transport. This can be done by generating some or all of the statistics presented in Tables 7 and 8. These statistics were obtained for AREAS.ASC (file 4) and NETFLUX.ASC (file 8) using the SAS ${ }^{\mathrm{TM}}$ software package (with the PROC MEANS command). These statistics may be duplicated using other statistical packages or computer languages.

These statistics are included as a tool to ensure proper reading of the two flat ASCII data files and should not be construed as either a summary or an indicator of trends in the data.

Table 7. Statistical characteristics of the numeric variables in AREAS.ASC

\begin{tabular}{lrrrrr} 
Variable & N & Mean & Std. Dev. & Minimum & Maximum \\
\hline & & & & & \\
A1700 & 40 & -4405.43 & 5126.08 & -9999.00 & 723.00 \\
A1850 & 40 & 179.75 & 200.68 & 14.00 & 750.00 \\
A1980 & 40 & 149.27 & 184.27 & 3.00 & 750.00 \\
CHANGE & 40 & -0.197 & 0.269 & -0.92 & 0.26
\end{tabular}


Table 8. Statistical characteristics of the numeric variables in NETFLUX.ASC

\begin{tabular}{lrrrrr}
\hline Variable & $\mathbf{N}$ & \multicolumn{1}{l}{ Mean } & Std. dev. & Minimum & Maximum \\
\hline & & & & & \\
YEAR & 141 & 1920.00 & 40.84 & 1850.00 & 1990.00 \\
NAM & 141 & -598.40 & 2608.10 & -9999.00 & 222.23 \\
SCAM & 141 & 196.11 & 187.10 & 19.16 & 595.39 \\
EURO & 141 & -668.80 & 2587.12 & -9999.00 & 71.53 \\
NAFM & 141 & -687.78 & 2581.78 & -9999.00 & 44.57 \\
TAF & 141 & 67.47 & 86.07 & 5.61 & 341.50 \\
FSU & 141 & -285.32 & 1869.96 & -9999.00 & 280.73 \\
CHIN & 141 & -643.60 & 2594.14 & -9999.00 & 147.96 \\
ASIA & 141 & 208.92 & 159.32 & 27.30 & 698.79 \\
PCDV & 141 & -678.33 & 2584.51 & -9999.00 & 93.87 \\
FLUX & 141 & -7.94 & 2784.16 & -9999.00 & 1423.08 \\
& & & & & \\
\hline
\end{tabular}




\section{VERIFICATION OF DATA TRANSPORT: LOTUS $1-2-3^{\mathrm{TM}}$ DATA FILES}

After loading the twenty Lotus $1-2-3^{\mathrm{TM}}$ files provided with this data package onto a system, the user should checked to ensure that the files have not been corrupted during transport. This can be done by obtaining the size of each file (in bytes) using operating system commands such as "ls -1" or "dir" and comparing the results with those presented in Table 9. If the file size obtained differs from those presented by more than 1 byte, then the file may have been corrupted in transport.

Table 9. File characteristics of the 20 Lotus $1-2-3^{\mathrm{TM}}$ spreadsheet files

File

name
File

contents
File

number
File

size
AREAS.WK1

NETFLUX.WK1

ASIA-RAT.WK1

CHIN-RAT.WK1

EURO-RAT.WK1

FSU-RAT.WK1

NAFM-RAT.WK1

NAM-RAT.WK1

PCDV-RAT.WK1

SCAM-RAT.WK1

TAF-RAT.WK1
Land areas for each ecosystem and region

Carbon fluxes for each region and the world

Rate files for:

South and Southeast Asia

China

Europe

Former Soviet Union

North Africa-Middle East

North America

Pacific Developed Region

South and Central America

Tropical Africa
5

7,200

9

29,700

10

10,600

11

5,400

12

5,500

13

5,700

14

4,800

15

10,900

16

5,300

17

10,700

18

3,500 
Table 9.

(continued)

File

name

File

contents

File

number

File

$\longrightarrow$

Response curve files for:

ASIA-RE.WK1 South and Southeast Asia

$19 \quad 5,400$

ASIA.SH.WK1 Shifting cultivation in

South and Southeast Asia

20

4,500

FSU-RE.WK1

Former Soviet Union

21

6,400

SCAM-RE.WK1 South and Central America

22

13,500

TAF-RE.WK1

Tropical Africa

23

3,900

TEM-RE.WK1

China, Europe, North Africa-

Middle East, North America, and Pacific Developed Region

24

8,800

Decay pool partition files for:

FSULOGPT.WK1

Former Soviet Union

25

4,600

TEMLOGPT.WK1

China, Europe, North Africa-

Middle East, North America, and Pacific Developed Region

MODEL-EX.WK1 Implementation of the carbon flux equations shown in this document for the Closed Forest ecosystem in Tropical Africa 
APPENDIXES 
APPENDIX A

DEFINITION OF ECOSYSTEM NAMES USED IN THIS DATABASE 



\section{DEFINITION OF ECOSYSTEM NAMES USED IN THIS DATABASE}

Many vegetation classification systems exist. Variations in these systems are based on the needs of the data consumer for whom they were developed. This database was developed to allow carbon fluxes from land use change to be derived; thus, an ecological classification system that could be converted into estimates of carbon content for a given ecosystem was needed. In this study the ecosystem names used within each region (see Part 1 , Table 2, which is reprinted on page A-7) were obtained by distributing the world vegetation types of Whittaker and Likens (1973) based on A.W. Küchler's map of natural vegetation (Espenshade 1986).

The definitions listed below were derived from Lanly (1982) and Strahler and Strahler (1984) and are provided to assist the data user in interpreting the ecosystem names used in this database. The ecosystem names combine three different concepts to obtain a descriptive name for each ecosystem. In general, each ecosystem name consists of a locational component, a vegetation descriptive term, and a biome name.

Ecosystems of the globe fall into two major groups, aquatic and terrestrial. In this study the focus is on terrestrial ecosystems. The terrestrial ecosystems have been divided into five biomes based on the availability of soil moisture and heat. Biomes include both the animal and plant life within the life layer; however, green vegetation dominates the biome due to its enormous biomass (Strahler and Strahler 1984). The principal biomes are listed below.

\section{Biomes}

Forest

Woodland (Open Forest)

Grassland

Desert
Abundant water and heat.

Consists of closely set trees whose crowns form a continuous canopy that provide shade for the ground and lower layers of vegetation.

Transitional biome between forest and grassland.

Consists of widely spaced trees whose crowns do not form a continuous canopy.

Ground is usually covered with a dense layer of grass, shrubs, or forbs.

Moderate water shortage, adequate heat.

Consists of tall or short grasses that form a continuous and dense cover.

Trees, shrubs, and forbs may occur in widely spaced patches near water sources.

Extreme water shortage, adequate heat.

Consists of sparse vegetation cover and areas of bare ground. Vegetation may consist of thomy trees and shrubs, cactus, hardy grass, and annuals that become dormant in the dry season. 
Insufficient heat.

Consists of low herbaceous plants and dwarf trees. Sedges, grasses, and lichen are also found.

Soil of this biome is frozen throughout the winter with only the top few feet thawing during the summer.

The ecosystem names used in this database often combine a biome name with a descriptive term for the world latitude zones. These zones identify world geographical belts that receive similar amounts of solar energy.

\section{Latitude Zones}

Equatorial

Tropical

Subtropical

Midlatitude

Subarctic (Subantarctic)

Arctic (Antarctic)

Polar
Latitude zone centered on the equator, within the range $10^{\circ} \mathrm{S}$ and $10^{\circ} \mathrm{N}$

Latitude zones centered on the tropics of Cancer and Capricom, within the ranges $10^{\circ}$ to $25^{\circ} \mathrm{N}$ and $10^{\circ}$ to $25^{\circ} \mathrm{S}$

Latitude zones within the ranges $25^{\circ}$ to $35^{\circ} \mathrm{N}$ and $25^{\circ}$ to $35^{\circ} \mathrm{S}$

Latitude zones within the ranges $35^{\circ}$ to $55^{\circ} \mathrm{N}$ and $35^{\circ}$ to $55^{\circ} \mathrm{S}$

Latitude zones within the ranges $55^{\circ}$ to $60^{\circ} \mathrm{N}$ and $55^{\circ}$ to $60^{\circ} \mathrm{S}$

Latitude zones within the ranges $60^{\circ}$ to $75^{\circ} \mathrm{N}$ and $60^{\circ}$ to $75^{\circ} \mathrm{S}$

Latitude zones within the ranges $75^{\circ}$ to $90^{\circ} \mathrm{N}$ and $75^{\circ}$ to $90^{\circ} \mathrm{S}$

For purposes of this database, two of the latitude zones (polar and arctic/antarctic) and one of the biomes (tundra) have not been used because the extreme cold temperatures experienced in these zones preclude the growth of significant amounts of vegetation. The latitude zones have been combined to form the following latitudinal regions.

\section{Latitudinal Regions}

Tropical

Temperate

Boreal
Includes the equatorial, tropical, and half of the subtropical zones

Includes half of the subtropical zones and the midlatitude zones

Includes the subarctic zone

$$
\text { A }-4
$$


Ecosystem names often contain a term that describes the dominant vegetation cover or the precipitation regime within a ecosystem (e.g., tropical moist forest, temperate deciduous forest). The terms used are as follows.

\section{Precipitation Regimes}

Moist

Seasonal

Warm

A continuously hot, frost-free climate with abundant precipitation in all months of the year.

A continuously hot, frost-free climate with marked seasonality in the distribution of rainfall. This variation in precipitation is often due to seasonal changes in the monsoon and trade winds.

A continuously cool, frost-free climate with abundant precipitation. This type occurs on highlands within the seasonal and moist regions.

\section{Dominant Vegetation Covers}

\section{Broadleaf}

Coniferous

Deciduous

Evergreen

Scrub
Occurs in moist climates of the subtropical and lower midlatitudes where winters are mild and precipitation is abundant most months of the year. The number of tree species and their size tends to be less than would be found in tropical rainforests with similar amounts of precipitation, leaves tend to be smaller and more leathery and the leaf canopy less dense.

Occurs in all cool locations of the world (e.g., tropical highlands). However, most of these forests occur in the subarctic and midlatitudes, where winters are cold, summers are warm, and water is adequate or abundant in the spring with shortages in the summer. The dominant tree species are straight-trunked, needle-leafed trees (pine) that provide deep shade to the ground. Species are few, with only one or two tree species often dominating hundreds of square miles.

Occurs in the midlatitudes where winters are cold, summers are warm, and precipitation is adequate all months of the year. Consists of tall broadleaf trees that develop a continuous canopy in the summer but shed their leaves in the winter. Lower layers are weakly developed, with a dense layer of herbs developing in the spring.

Occurs in climates where the dominant tree species grow continuously throughout the year.

Occurs in hot locations of the world that experience long dry seasons with brief, but intense, rainy periods. Vegetation cover consists of small drought-tolerant trees, shrubs, grasses, and cactus.

$$
\text { A }-5
$$


Based on the definitions shown in this appendix, the ecosystem names used for each of the nine regions of the world may be compared. In several cases, the reader will note that different names have been used for regions with similar ecosystems (e.g., tropical equatorial forest in South and Central America and tropical moist forest in South and Southeast Asia). This "duplication" is caused by the different terminology found in the original data sources.

Because of data limitations in Tropical Africa, the ecosystem types were combined into a open and a closed forest category; in South and Southeast Asia, distinctions were made between degraded and undisturbed ecosystems. The two Tropical African ecosystem names are super sets of the following ecosystem types.

Special Ecosystems Types in Tropical Africa and South and Southeast Asia

Closed Forest

Open Forest

Degraded

Undisturbed
Includes the tropical equatorial forest, tropical seasonal forest, and warm coniferous forest ecosystems (including bamboo forests)

Includes the tropical woodland ecosystems

Land where the gradual removal of carbon over long periods of time (e.g., removal for firewood) has reduced the amount of carbon in the ecosystem

Land where external forces have not altered the amount of carbon in the ecosystem (all ecosystems are assumed to be in this state unless stated otherwise) 
Table 2 from Part 1 of this document is reprinted here to allow the data user to partition the ecosystem names used for each region based on the definitions provided in this appendix.

Natural ecosystems within each of the nine regions

North America

Temperate Evergreen Forest

Temperate Grassland

Boreal Forest

South and Central America

Tropical Equatorial Forest

Tropical Woodland

Temperate Broadleaf Forest

Desert Scrub

Europe

Temperate Evergreen Forest Boreal Forest

North Africa-Middle East

Temperate Evergreen Forest

Tropical Moist Forest

Desert Scrub

Tropical Africa

Closed Forest

(includes Bamboo Forests)

Former Soviet Union

Temperate Deciduous Forest

Temperate Grassland

China

Temperate Evergreen Forest

Temperate Deciduous Forest

South and Southeast Asia

Degraded:

Tropical Moist Forest

Tropical Seasonal Forest

Undisturbed:

Tropical Moist Forest

Tropical Seasonal Forest
Temperate Deciduous Forest

Temperate Woodland and Shrubland

Tropical Seasonal Forest

Warm Coniferous Forest

Grassland

Temperate Grassland

Temperate Deciduous Forest

Tropical Grassland

Tropical Woodland and Shrubland

Open Forest

Boreal Forest

Temperate Grassland

Tropical Moist Forest

Tropical Open Forest

Tropical Grassland

Tropical Open Forest

Tropical Grassland 
(continued)

Pacific Developed Region

Temperate Evergreen Forest

Tropical Moist Forest

Tropical Woodland and Shrubland

Temperate Deciduous Forest

Tropical Grassland

Desert Scrub

\section{References}

Espenshade, E. B., Jr. 1986. Goode's World Atlas. 17th ed., Rand McNally and Company, Chicago.

Lanly, J.-P. 1982. Tropical Forest Resources. Forestry Paper No. 30, Food and Agriculture Organization of the United Nations, Rome.

Strahler, A. N. and A. H. Strahler. 1984. Elements of Physical Geography, 3rd Edition. John Wiley and Sons, New York.

Whittaker, R. H. and G. E. Likens. 1973. Carbon in the biota. pp. 281-302. In Carbon and the Biosphere, Woodwell, G. M. and E. V. Pecan (eds.). Proceedings of the 24th Brookhaven Symposium in Biology, CONF-720510, U.S. Atomic Energy Commission, Springfield, Virginia. 
APPENDIX B

VEGETATION-SOIL RESPONSE CURVE PRINTOUTS FOR THE NINE REGIONS 


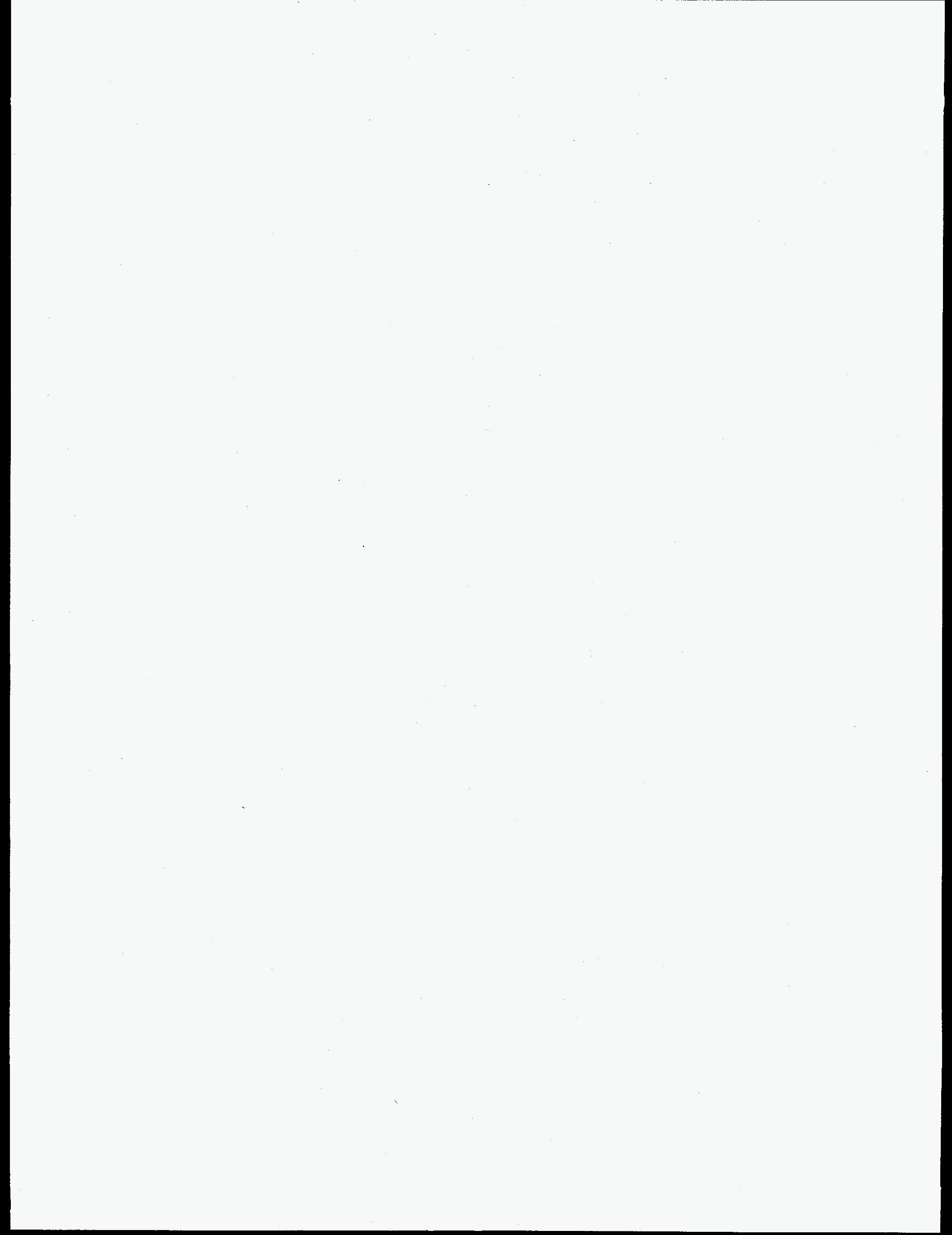




\section{VEGETATION-SOIL RESPONSE CURVE PRINTOUTS FOR THE NINE REGIONS}

Each region has a set of ecosystem response curves that contain information on the initial carbon content (per hectare) of vegetation and soil in each region and information on how the carbon would be released to the atmosphere from a given type of disturbance (e.g., clearing for cropland). The data contained in these response curves include information on: the minimum carbon content reached after clearing; time (in years) to reach this minimum; carbon in live vegetation (e.g., crops) left on site; time for carbon levels to recover after abandonment; time for recovered area to reach initial carbon levels; and the fraction of cleared vegetation assigned to five decay pools (i.e., the carbon in harvested vegetation decays at different rates based on the use to which the vegetation was put). The first decay pool contains slash and dead vegetation left on site at the time of clearing. Biomass in this pool is released to the atmosphere based on an ecosystem and region specific on-site decay rate. The second is the 1-year decay pool. It is assumed that biomass assigned to this pool is bumed and is released to the atmosphere in the year following clearing. The third, forth, and fifth pools are the 10-, 100-, and 1000-year decay pools. The biomass assigned to these pools are released to the atmosphere using a $0.1,0.01$, or 0.001 decay constant.

Six response curve spreadsheets our included with this database. Data for the nine regions of the world are contained in the following six files: ASIA-RE.WK1 and ASIA-SH.WK1 (South and Southeast Asia), FSU-RE.WK1 (Former Soviet Union), SCAM-RE.WK1 (South and Central America), TAF-RE.WK1 (Tropical Africa), and TEM-RE.WK1 (China, Europe, North Africa-Middle East, North America, and Pacific Developed Region). Because the partitioning of carbon between decay pools changes over time in the industrial and nonindustrial logging response curves for five of the worlds nine regions (i.e., China, Europe, North Africa-Middle East, North America, the Former Soviet Union, and Pacific Developed Region), two special files containing decay pool partitioning data were developed. Partitioning data for logging in the Former Soviet Union is contained in file FSULOGPT.WK1, while partitioning data for China, Europe, North Africa-Middle East, North America, and the Pacific Developed Region are in TEMLOGPT.WK1.

The printouts in this appendix are from the six response spreadsheets (ASIA-RE.WK1, ASIA-SH.WK1, FSU-RE.WK1, SCAM-RE.WK1, TAF-RE.WK1, and TEM-RE.WK1) and the two special partitioning spreadsheets (FSULOGPT.WK1 and TEMLOGPT.WK1). The first line of each file contains a list of the regions for which the data are applicable. 
TEM-RE.WK1

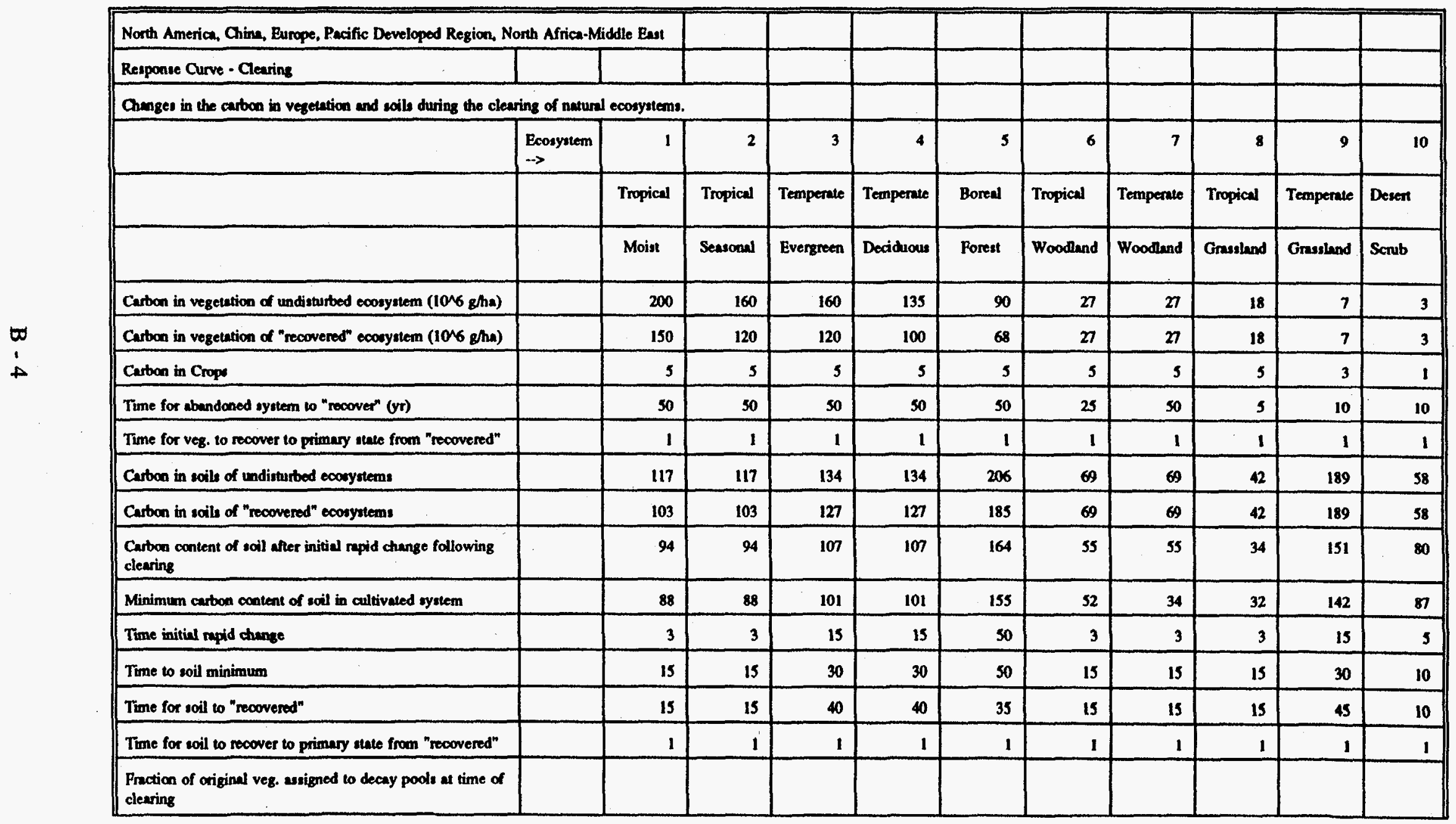




\begin{tabular}{|c|c|c|c|c|c|c|c|c|c|c|c|}
\hline $1-\mathbf{y r}$ & & 0.4 & 0.4 & 0.4 & 0.4 & 0.4 & 0.4 & 0.4 & 0.5 & 0.5 & 0.5 \\
\hline 10-yr & & 0.27 & 0.27 & 0.2 & 0.2 & 0.2 & 0.1 & 0.1 & $\mathbf{0}$ & $\mathbf{0}$ & 0 \\
\hline $100-y r$ & & $\mathbf{0}$ & $\mathbf{0}$ & 0.07 & 0.07 & 0.07 & $\mathbf{0}$ & $\mathbf{0}$ & $\mathbf{0}$ & 0 & $\mathbf{0}$ \\
\hline $1000-y r$ & & $\mathbf{0}$ & $\mathbf{0}$ & 0 & $\mathbf{0}$ & 0 & $\mathbf{0}$ & 0 & $\mathbf{0}$ & & \\
\hline Left to decay on site & & 0.33 & 0.33 & 0.33 & 0.33 & 0.33 & 0.5 & 0.5 & 0.5 & 0.5 & 0.5 \\
\hline Rete constunt for on-site decay & & 0.5 & 0.4 & 0.05 & 0.05 & 0.03 & 0.3 & 0.4 & 0.4 & 0.3 & $\mathbf{0 . 3}$ \\
\hline \multicolumn{12}{|c|}{ North America, Chinn, Europe, Pucific Developed Region, North Africa-Middle East } \\
\hline \multicolumn{12}{|l|}{ Response Curve - Logzing } \\
\hline \multicolumn{12}{|c|}{ Chunges in the carton in vegetation end soils during the clearing of netural econystems for logging. } \\
\hline & $\begin{array}{l}\text { Ecoaystem } \\
\rightarrow \rightarrow \\
\end{array}$ & 1 & 2 & 3 & 4 & 5 & & & & & \\
\hline & & Moist & Seasonal & Evergreen & Deciduous & Forest & & & & & \\
\hline Carbon in vegetution of undirturbed econystem (1046 gha) & & 200 & 160 & 160 & 135 & 90 & & & & & \\
\hline Carbon in vegetation of "rocovered" cocosstem (1066 g/ha) & & 150 & 120 & 120 & 100 & 68 & & & & & \\
\hline Carbon left in live forest on sile & & 5 & 5 & 5 & 5 & 5 & . & & & & \\
\hline Time for abandoned aystem to "recover" (yr) & & 50 & 50 & so & 50 & 50 & & & & & \\
\hline Time for veg. to recover to primary ature from "recovered" & & 1 & 1 & 1 & 1 & 1 & & & & & \\
\hline Carbon in ecils of undisturbed coonyalems & & 117 & 117 & 134 & 134 & 206 & & & & & \\
\hline Carbon in roils of "recovered" cocrysucms & & 103 & 103 & 127 & 127 & 185 & & & & & \\
\hline $\begin{array}{l}\text { Carton content of soil after initial nuid change following } \\
\text { clearing }\end{array}$ & & 76 & 76 & 108 & 108 & 165 & & & & & \\
\hline
\end{tabular}




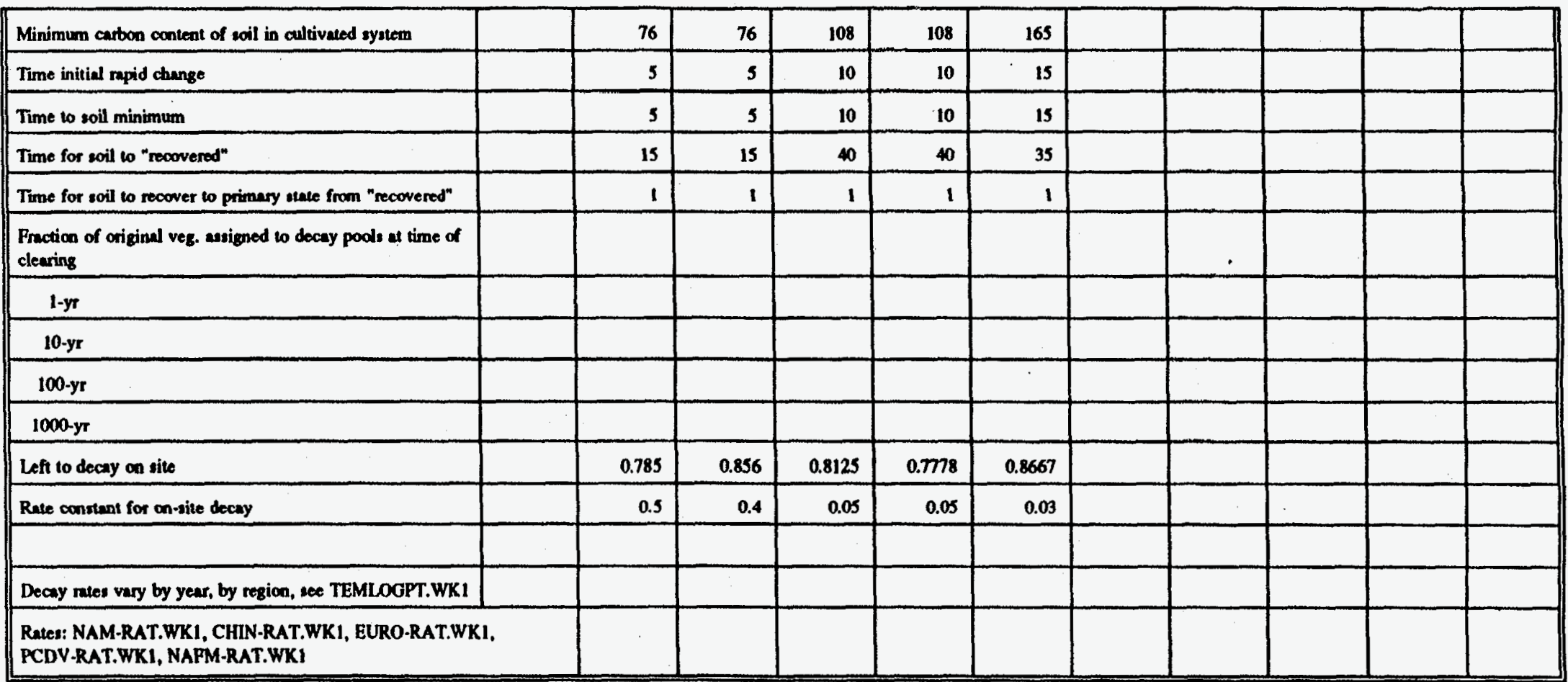

CDV-RAT.WKI, NAFM-RAT.WK 
TEMLOGPT.WK1

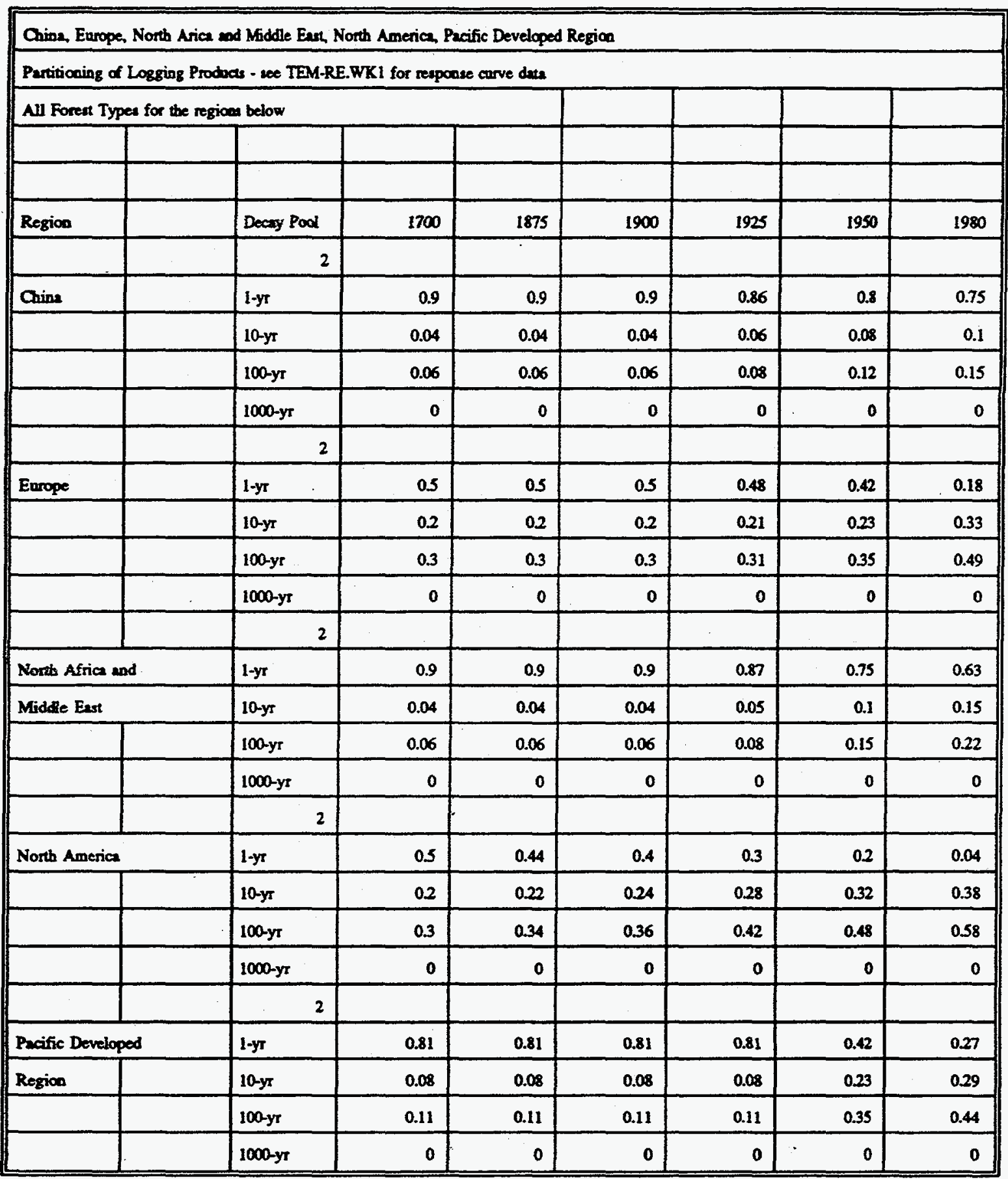




\section{SCAM-RE.WK1}

\begin{tabular}{|c|c|c|c|c|c|c|c|c|}
\hline South and Central America & & & & & & & & \\
\hline \multicolumn{9}{|l|}{ Response Curve - Clearing } \\
\hline \multicolumn{9}{|c|}{ The fue of carbon in vegetation and soils following the clearing of natural econystems for cropland. } \\
\hline & $\begin{array}{l}\text { Ecosystem } \\
\rightarrow \rightarrow\end{array}$ & 1 & 2 & 3 & 4 & 5 & 6 & 7 \\
\hline & & Tropical & Tropical & Tropical & Warm & Temperate & Grussland & Dewert \\
\hline & & Equatorial & Sensomal & Woodland & Coniferous & \multicolumn{2}{|l|}{ Bromdleaved } & Scrub \\
\hline Carbon in vegetution of undisturbed ecosystem $(1046 \mathrm{~g} / \mathrm{ha})$ & & 200 & 140 & 55 & 168 & 100 & 10 & 6 \\
\hline Carbon in vegetution of "recovered" ecosystem (10/6 g/ha) & & 200 & 140 & 55 & 168 & 100 & 10 & 6 \\
\hline Carbon in Crope & & 5 & 5 & 5 & 5 & 5 & 5 & 5 \\
\hline Time for abandoned aystem to "rocover" (yr) & & 40 & 35 & 18 & 42 & 25 & 2 & 1 \\
\hline Time for veg. to recover to primary atute from "recovered" & & 1 & 1 & 1 & 1 & 1 & 1 & 1 \\
\hline Carton in soils of undisturted econystems & & 98 & 98 & 69 & 134 & 134 & 42 & 58 \\
\hline Carbon in soils of "recovered" ecosystems & & 98 & 98 & 69 & 134 & 134 & 42 & 58 \\
\hline $\begin{array}{l}\text { Carbon content of soil after initial rapid change following } \\
\text { clearing }\end{array}$ & & 78 & 78 & 55 & 107 & 107 & 34 & 46 \\
\hline Minimum carton content of acil in cultivated aystem & & 74 & 74 & 52 & 100 & 100 & 32 & 44 \\
\hline Time initial rapid change & & 5 & 5 & 5 & 5 & 5 & 5 & 5 \\
\hline Time to soil minimum & & 20 & 20 & 20 & 20 & 20 & 20 & 20 \\
\hline Time for soil to "recovered" & & 40 & 35 & 18 & 42 & 40 & 2 & 1 \\
\hline Time for soil to rocover to primary state from "recovered" & & 1 & 1 & 1 & $\mathbf{1}$ & 1 & 1 & 1 \\
\hline \multicolumn{9}{|l|}{$\begin{array}{l}\text { Praction of original veg. asigned to decay pools al time of } \\
\text { clearing }\end{array}$} \\
\hline 1-yr & & 0.3 & 0.3 & 0.3 & 0.3 & 0.3 & 0.48 & 0.48 \\
\hline
\end{tabular}




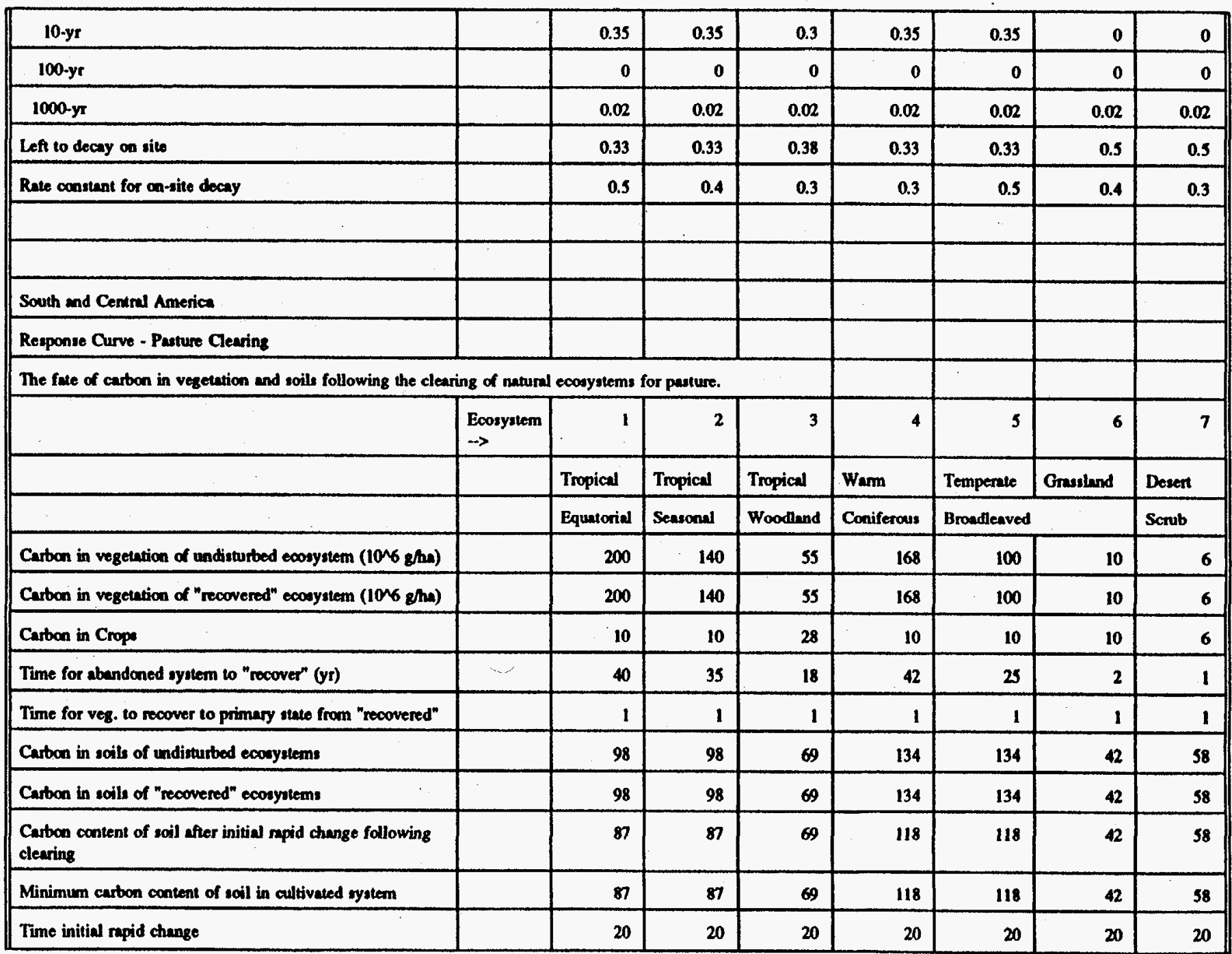




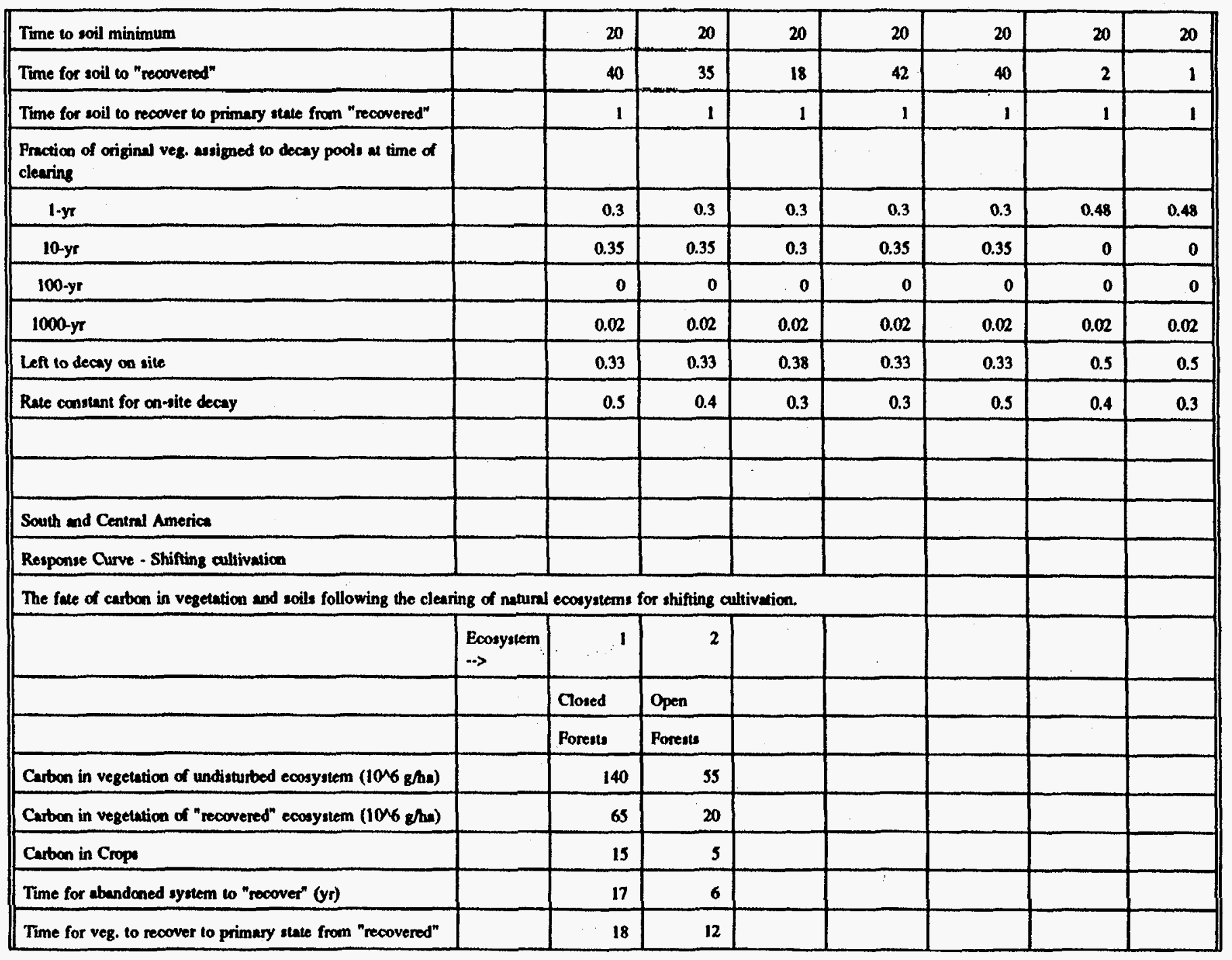




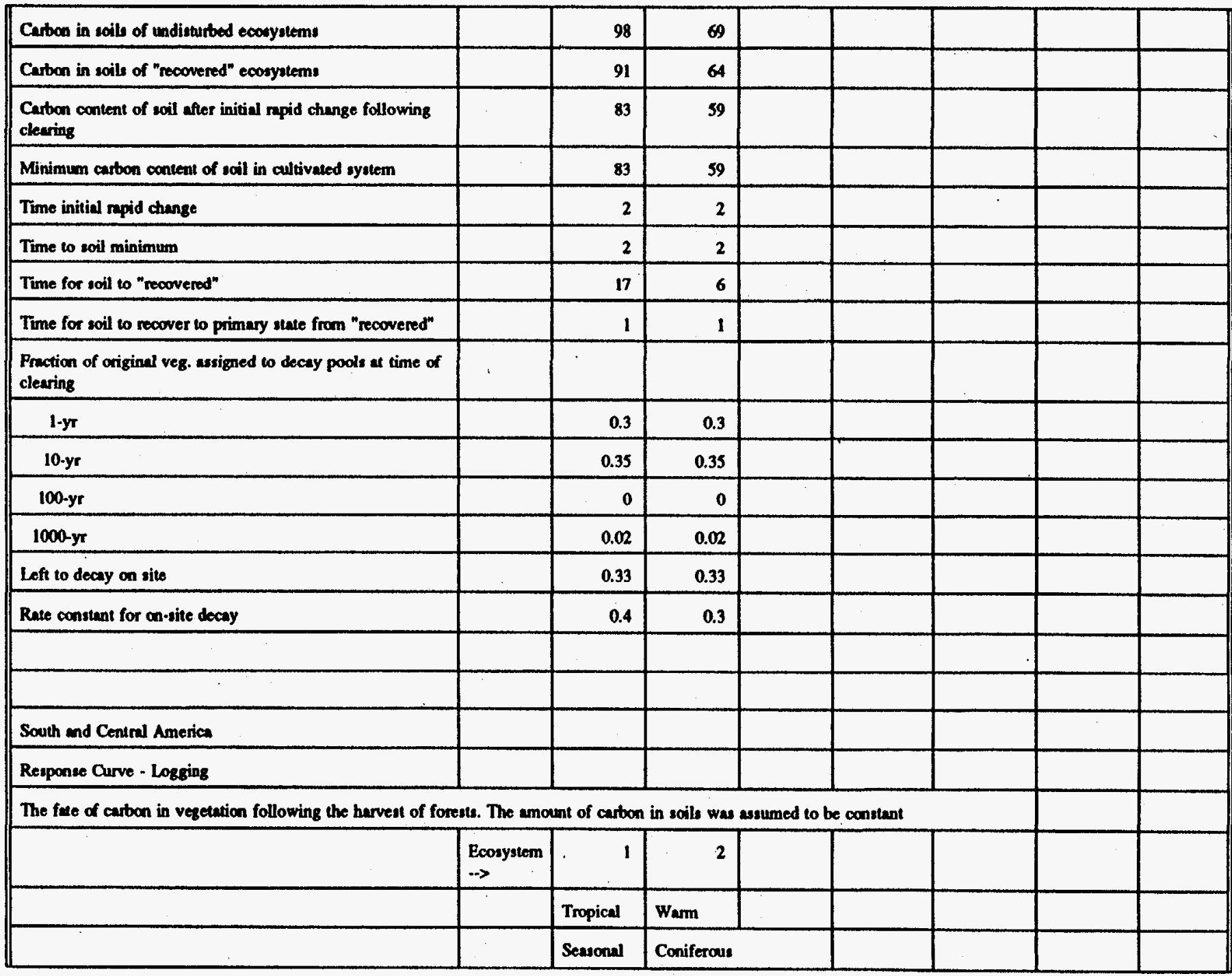




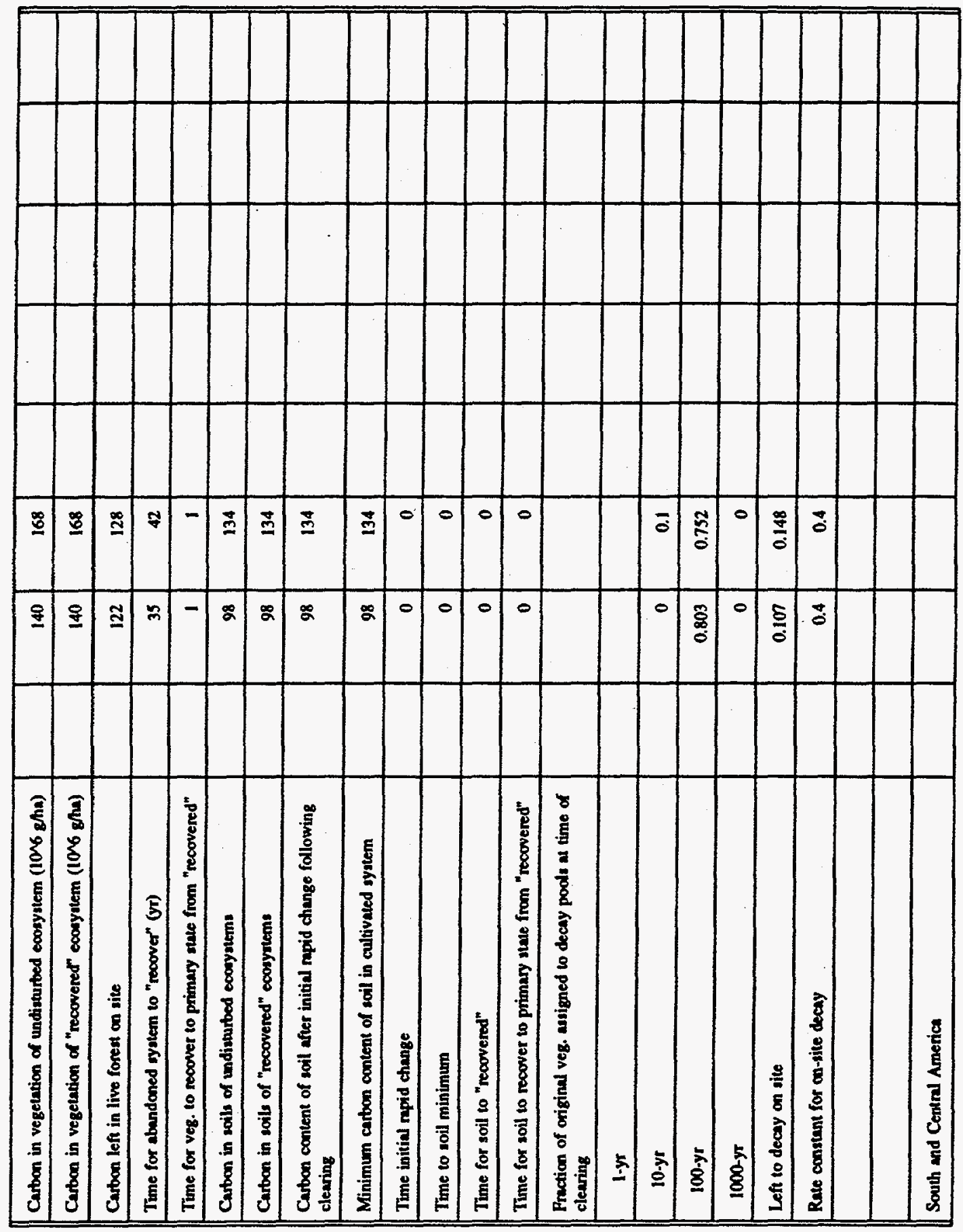

B -12 


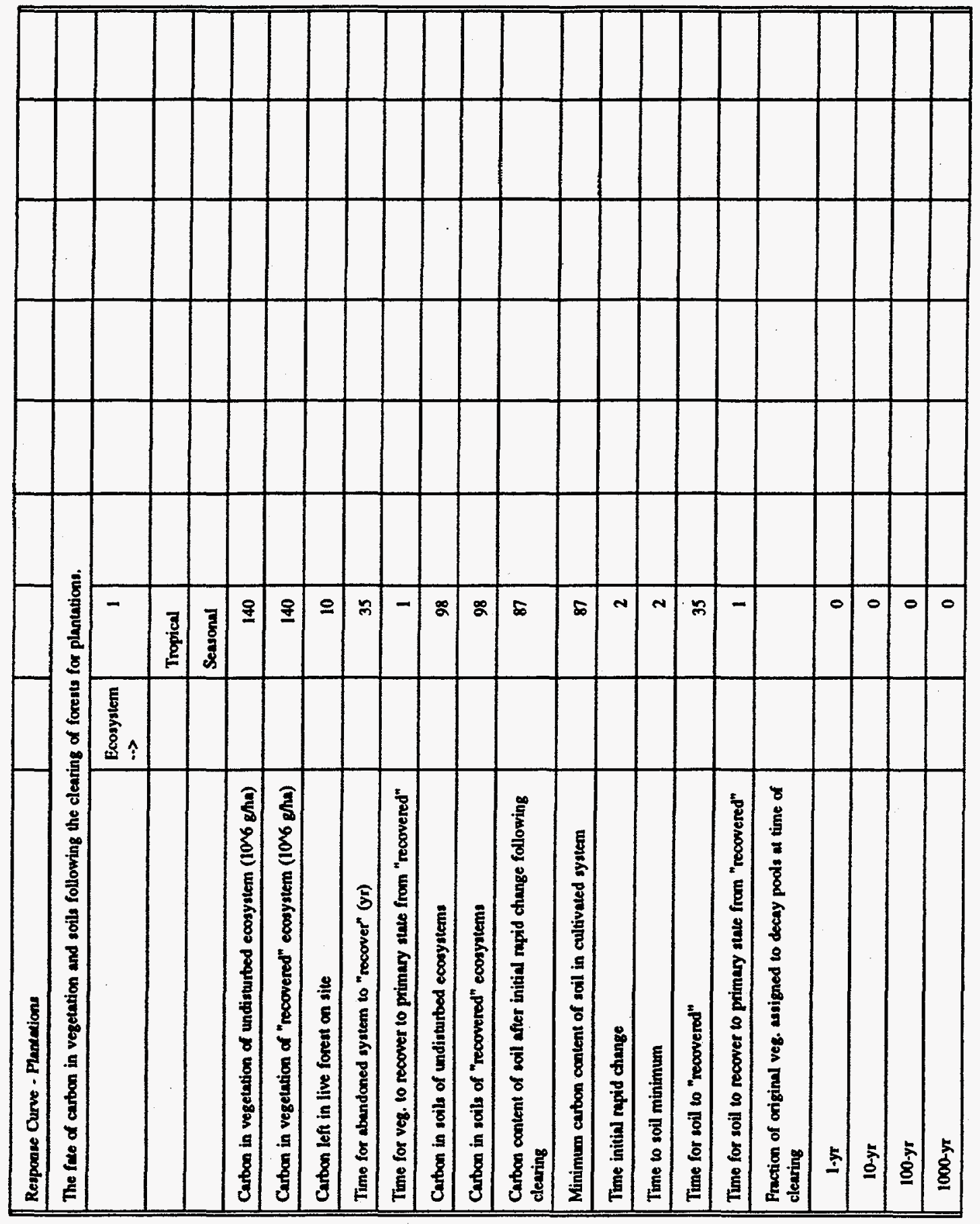

B - 13 


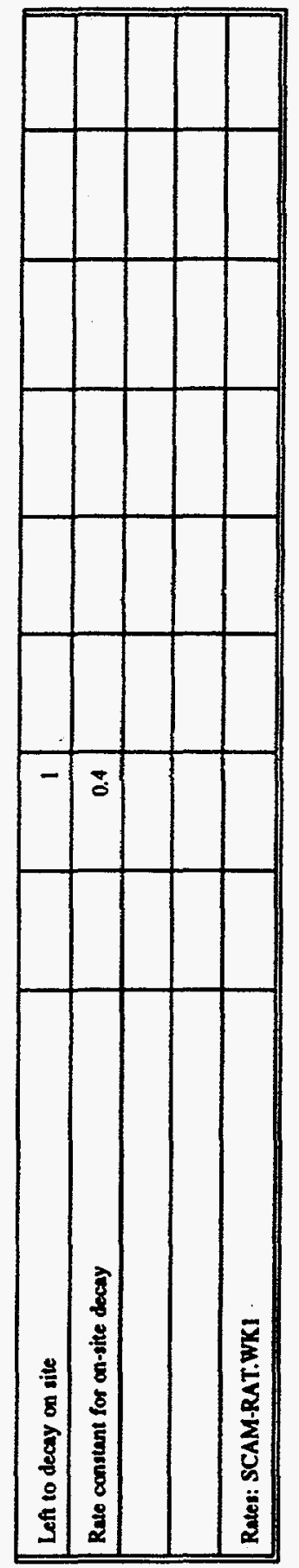

B - 14 


\section{TAF-RE.WK1}

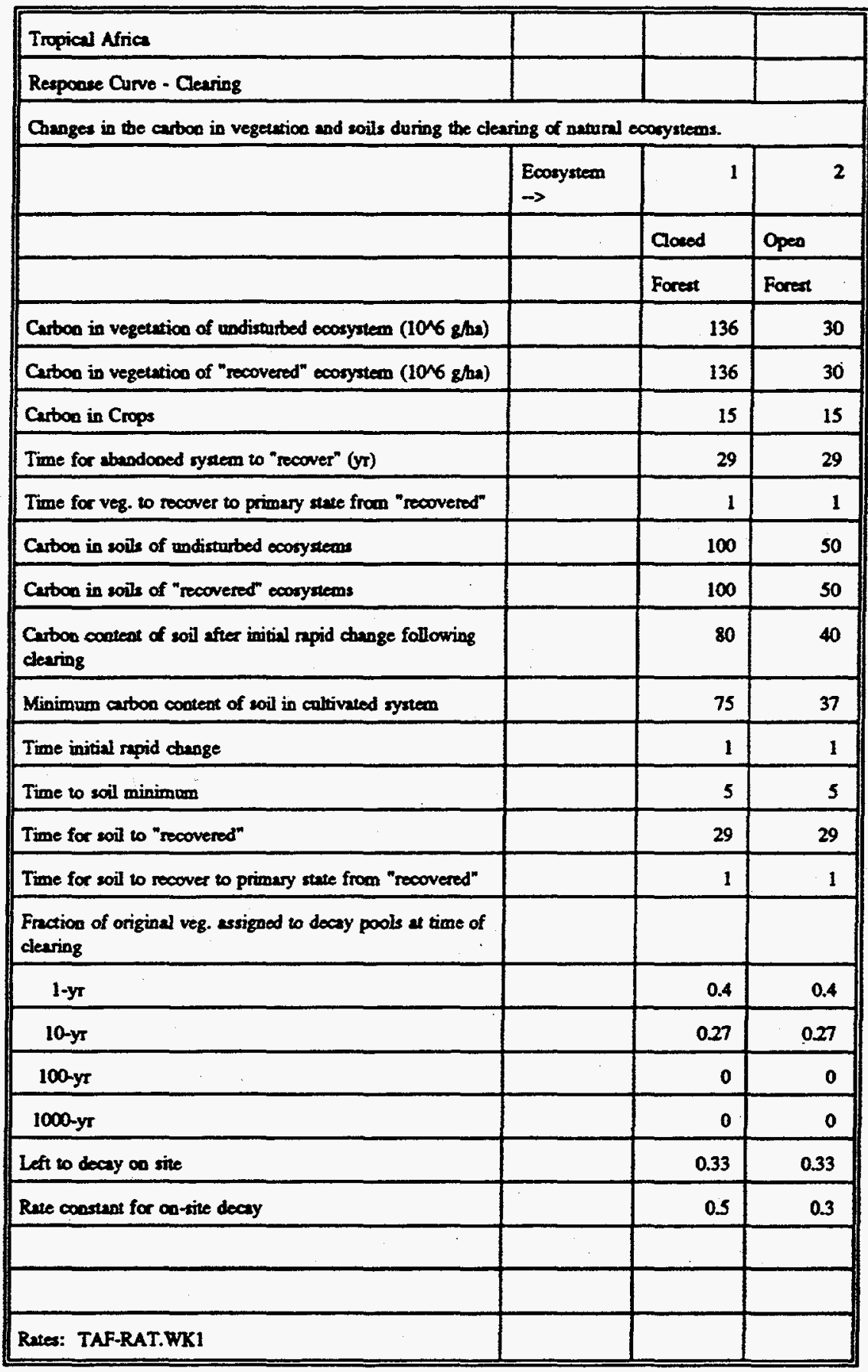




\section{FSU-RE.WK1}

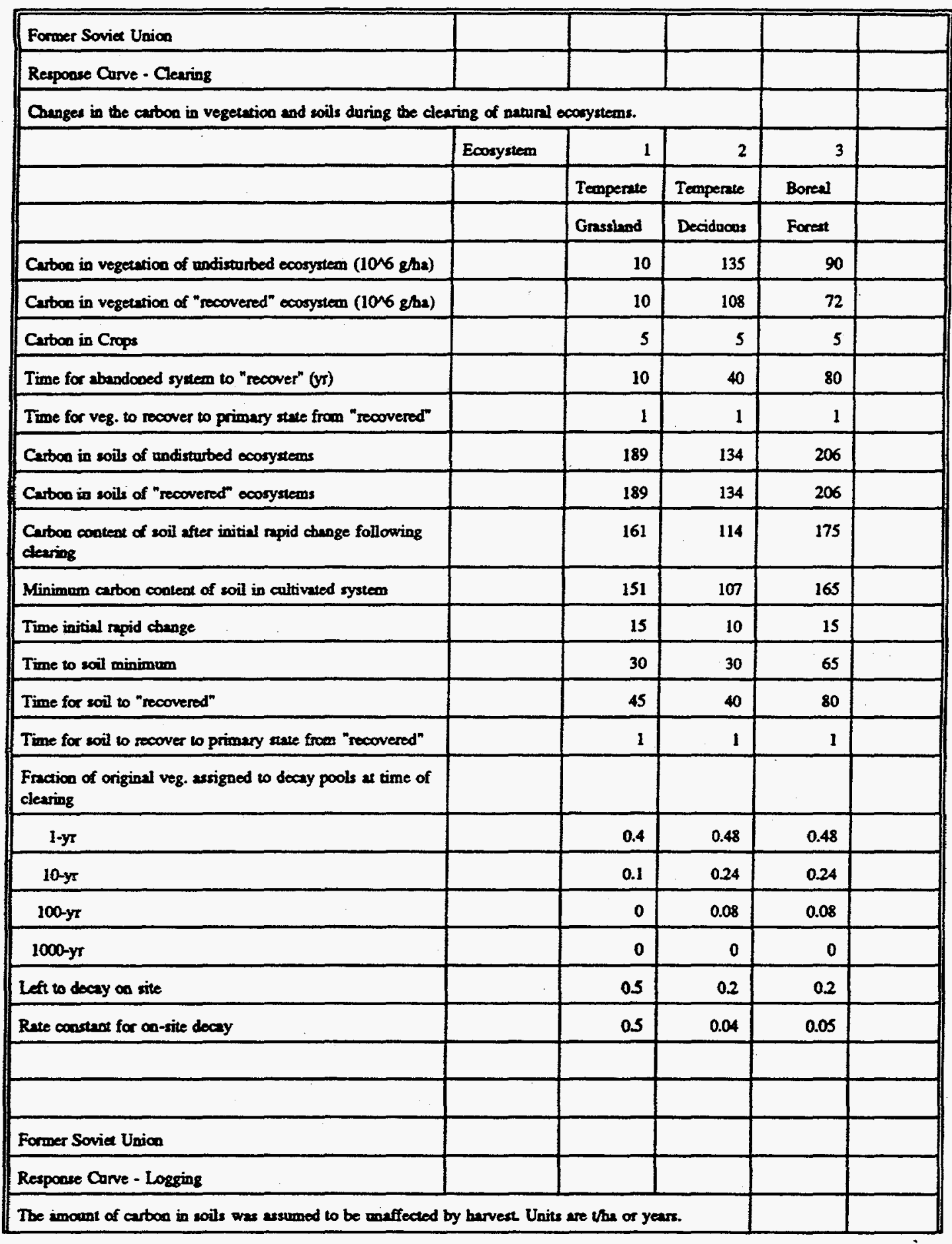




\begin{tabular}{|c|c|c|c|c|c|}
\hline & Ecosystem & 1 & 2 & 3 & 4 \\
\hline & & \multicolumn{2}{|c|}{ Nonindustrial Harvest } & \multicolumn{2}{|c|}{ Industrial Logging } \\
\hline & & Teosperate & Boreal & Temperate & Boreal \\
\hline . & & Deciduons & Forest & Deciduous & Foreat \\
\hline Carbon in vegeturion of undisurbed ecorystem (10/6 $\mathrm{g} / \mathrm{ha})$ & & 135 & 90 & 135 & 90 \\
\hline Carbon in vegetation of "rocovered" econystem (1046 g/ma) & & 108 & 72 & 108 & 72 \\
\hline Curboa left in uncleared forest on sire & & 97 & 46 & 0 & $\mathbf{0}$ \\
\hline Time for abandoned aystem to "recover" (yr) & & 14 & $29^{\prime}$ & 40 & 80 \\
\hline Time for veg. to recover to primary stute from "recoverod" & & 1 & 1 & 1 & 1 \\
\hline Carbon in soils of modistubed ecosystems & & 134 & 206 & 134 & 206 \\
\hline Curbon in roils of "recovered" ecosystems. & & 134 & 206 & 134 & 206 \\
\hline $\begin{array}{l}\text { Curton cootent of soil after ivitial rapid change following } \\
\text { elearing }\end{array}$ & & 124 & 72 & 108 & 72 \\
\hline Minimum carbon content of toil in cuitivated system & & 124 & 72 & 108 & 72 \\
\hline Time initiel repid change & & 4 & 5 & 10 & 15 \\
\hline Time to soil minimum & & 4 & 5 & 10 & 15 \\
\hline Time for soil to "recovered" & & 10 & 24 & 30 & 65 \\
\hline Time for toil to recover to primary stute from "recovered" & & 1 & 1 & 1 & 1 \\
\hline \multicolumn{6}{|l|}{$\begin{array}{l}\text { Fraction of original veg. assigned to decay pools at time of } \\
\text { clearing }\end{array}$} \\
\hline \multicolumn{6}{|l|}{$1-y r$} \\
\hline \multicolumn{6}{|l|}{$10-y x$} \\
\hline \multicolumn{6}{|l|}{$100-y r$} \\
\hline \multicolumn{6}{|l|}{$1000-y x$} \\
\hline Left to decay on site & & 0.059 & 0.1 & 0.704 & 0.444 \\
\hline Rute coostans for co-rite decay & & 0.04 & 0.05 & 0.04 & 0.05 \\
\hline \multicolumn{6}{|l|}{ Decay rutea vary by year, soe FSULOGPT.WKI } \\
\hline Rute: FSU-RAT.WKI & & & & & \\
\hline
\end{tabular}




\section{FSULOGPT.WK1}

\begin{tabular}{|c|c|c|c|c|c|c|}
\hline Former Soviat Unica & & & & & & \\
\hline \multicolumn{7}{|c|}{ Partitioning of Logging Products - see FSU-RE.WK1 for response curve duts } \\
\hline \multicolumn{7}{|c|}{ Temperate Deciduous Foreat } \\
\hline & Decay Pool & 1700 & 1945 & 1960 & 1975 & 1980 \\
\hline & 2 & & & & & \\
\hline \multirow[t]{6}{*}{ Industrial Logging } & $1-\mathrm{yr}$ & 0.21407 & 0.40296 & 0.18259 & 0.11333 & 0.0944 \\
\hline & $10-y \pi$ & 0.00000 & 0.00000 & 0.00000 & 0.00000 & 0.00000 \\
\hline & $100-y r$ & 0.41556 & 0.22667 & 0.44704 & 0.51630 & 0.53519 \\
\hline & $1000-\mathrm{yr}$ & $\mathbf{0}$ & 0 & 0 & 0 & 0 \\
\hline & & $1700-1944$ & 1945-1959 & $1960-1974$ & $1975-1979$ & $1980-1985$ \\
\hline & 1 & & & & & \\
\hline \multirow[t]{4}{*}{ Non-industrial Logging } & $1-y \mathrm{r}$ & 0.71132 & 0.73342 & 0.59211 & 0.65211 & 0.64737 \\
\hline & $10-\mathrm{yr}$ & 0.00000 & 0.00000 & 0.00000 & 0.00000 & 0.00000 \\
\hline & $100-y r$ & 0.07816 & 0.05605 & 0.19737 & 0.13737 & 0.14211 \\
\hline & $1000-y r$ & 0 & 0 & 0 & 0 & 0 \\
\hline \multicolumn{7}{|l|}{ Boreal Forest } \\
\hline & Decay Pool & 1700 & 1945 & 1960 & 1975 & 1980 \\
\hline & 2 & & & & & \\
\hline \multirow[t]{6}{*}{ Industrial Logging } & $1-y t$ & 0.23611 & 0.44444 & 0.20139 & 0.12500 & 0.10417 \\
\hline & $10-y r$ & 0.00000 & 0.00000 & 0.00000 & 0.00000 & 0.00000 \\
\hline & $100-y x$ & 0.45833 & 0.25000 & 0.49306 & 0.56944 & 0.59028 \\
\hline & $1000-y r$ & 0 & 0 & 0 & 0 & 0 \\
\hline & & $1700-1944$ & $1945-1959$ & $1960-1974$ & $1975-1979$ & $1980-1985$ \\
\hline & 1 & & & & & \\
\hline \multirow[t]{4}{*}{ Non-indestrial logging } & 1-yr & 0.71670 & 0.73898 & 0.59659 & 0.65705 & 0.6522 \\
\hline & $10-\mathrm{yr}$ & 0.00000 & 0.00000 & 0.00000 & 0.000000 & 0.00000 \\
\hline & $100-\mathrm{yr}$ & 0.07875 & 0.05648 & 0.19886 & 0.13841 & 0.14318 \\
\hline & $1000-y r$ & 0 & $\mathbf{0}$ & 0 & 0 & 0 \\
\hline
\end{tabular}


ASIA-RE.WK1

\begin{tabular}{|c|c|c|c|c|c|c|c|c|}
\hline South and Southeast Aria & & & & & & & & \\
\hline \multicolumn{9}{|l|}{ Response Curve - Clearing } \\
\hline \multicolumn{9}{|c|}{ Ohmges in the carbon in vegettation and soils during the clearing of nutural ecosystems. } \\
\hline & $\begin{array}{l}\text { Ecosystem } \\
\rightarrow \rightarrow\end{array}$ & 1 & 2 & 3 & 4 & 5 & 6 & 7 \\
\hline & & Moist & Seasonal & Woodlend & Moist & Sensonal & Woodina & Grassland \\
\hline & & Degraded & Degraded & Degraded & Undisturbed & Undiaturbed & Undisturbed & (in pasture) \\
\hline Caston in vegetution of undisturbed ecosystem (10/6 g/ha) & & 135 & 150 & 40 & 250 & 150 & 60 & 60 \\
\hline Curbon in vegetation of "rocovered" conyntem $(1046 \mathrm{~g} / \mathrm{ha})$ & & 135 & 150 & 40 & 250 & 150 & 60 & 60 \\
\hline Carbon in Crops & & 5 & 5 & 5 & 5 & 5 & 5 & 60 \\
\hline Time for abandoned syreem to "recover" (yr) & & 37 & 29 & 12 & 37 & 29 & 12 & 12 \\
\hline Tume for veg. to recover to primary stute from "recovered" & & 1 & $\mathbf{1}$ & 1 & 1 & 1 & 1 & 1 \\
\hline Carbon in soils of undisturbed econystems & & 120 & 80 & 50 & 120 & 80 & 50 & 50 \\
\hline Curbon in scails of "recovered" econystems & & 120 & 80 & 50 & 120 & 80 & 50 & 50 \\
\hline $\begin{array}{l}\text { Carbon content of soil after initial mpid change following } \\
\text { clearing }\end{array}$ & & 96 & 64 & 40. & 96 & 64 & 40 & 50 \\
\hline Minimurn carbon content of soil in cultivated system & & 84 & 56 & 37 & 84 & 56 & 37 & 50 \\
\hline Time initial napid change & & 1 & 5 & 5 & 1 & 5 & 5 & 5 \\
\hline Time to soil minimum & & 6 & 7 & 5 & 5 & 5 & 5 & 5 \\
\hline Time for soil to "recovered" & & 35 & 29 & 12 & 35 & 29 & 12 & 12 \\
\hline Time for soil to recover to primary state from "recovered" & ' & 1 & 1 & 1 & 1 & 1 & 1 & 1 \\
\hline \multicolumn{9}{|l|}{$\begin{array}{l}\text { Praction of original veg. asigned to decay pools at time of } \\
\text { clearing }\end{array}$} \\
\hline $1-\mathrm{yr}$ & & 0.4 & 0.4 & 0.4 & 0 & $\mathbf{0}$ & $\mathbf{0}$ & 0.4 \\
\hline
\end{tabular}




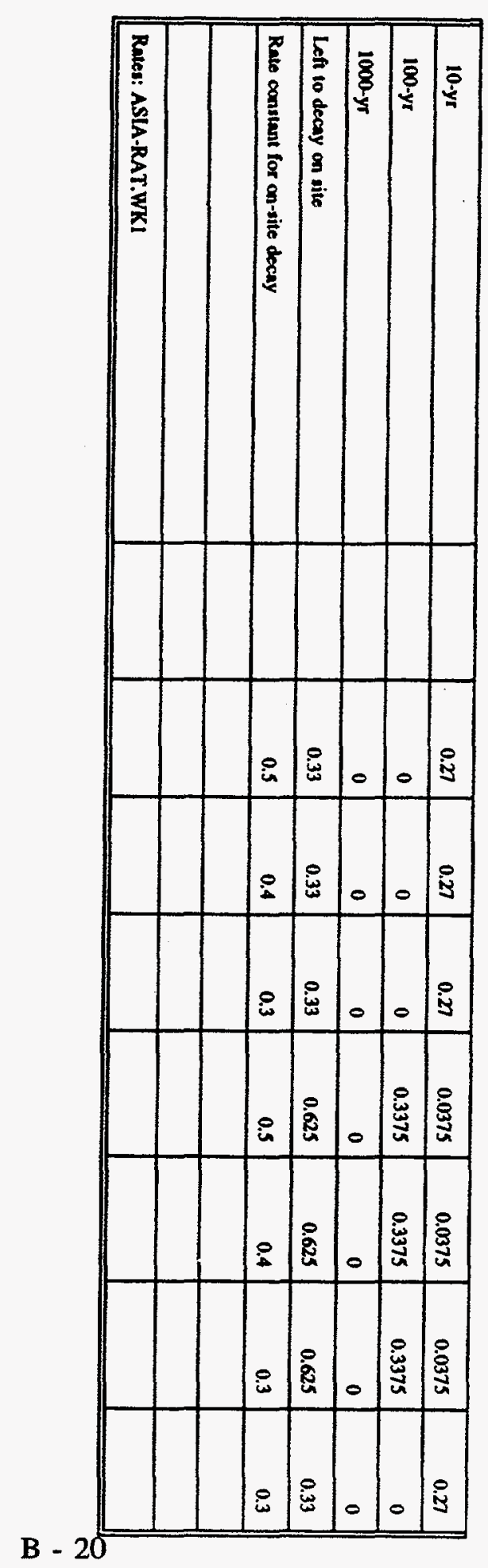




\section{ASIA-SH.WK1}

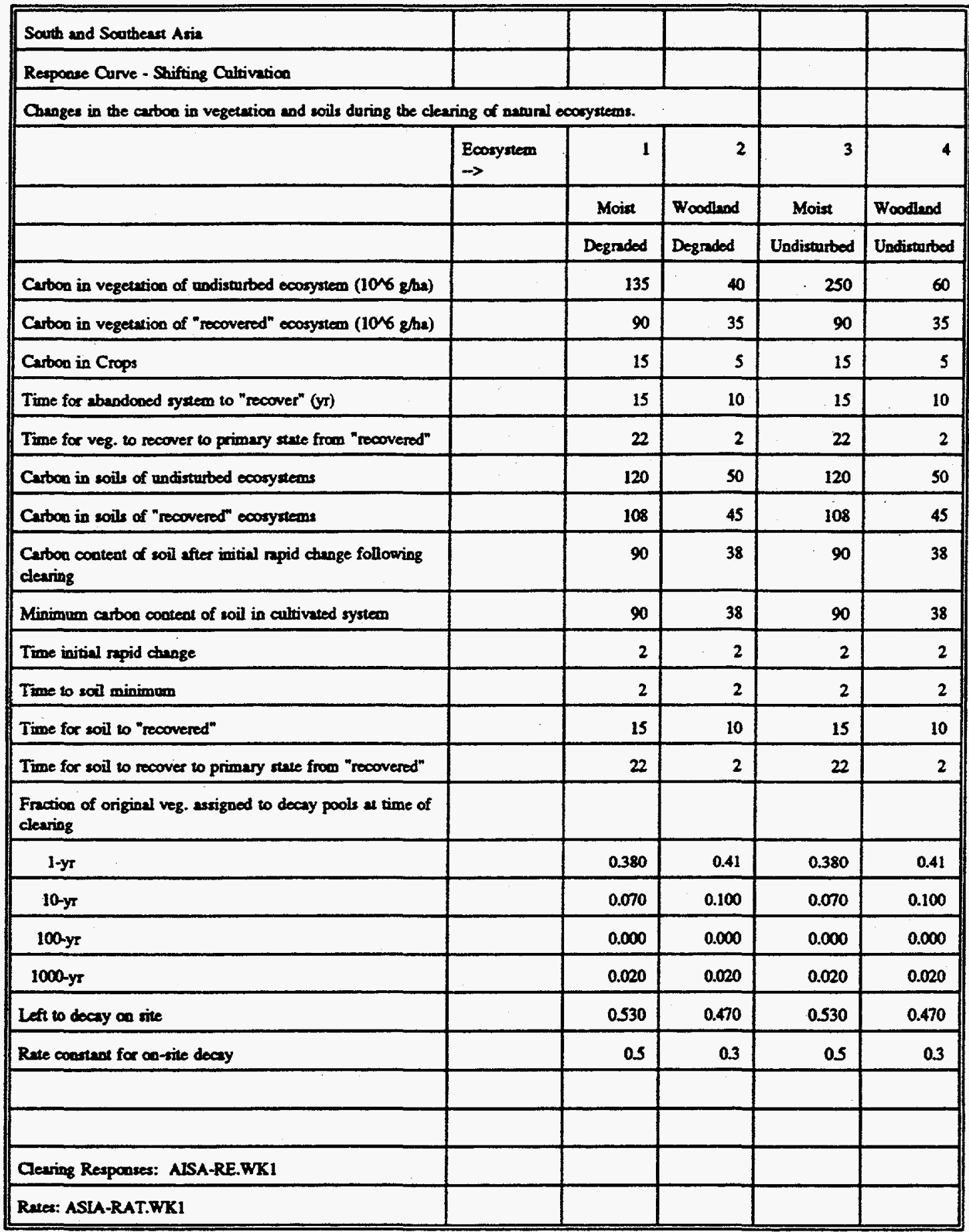


B - 22 


\begin{abstract}
APPENDIX C
PRINTOUT OF THE CALCULATED CARBON FLUX FOR ALL NINE REGIONS AND THE WORLD
\end{abstract}





\section{PRINTOUT OF THE CALCULATED CARBON FLUX FOR ALL NINE REGIONS AND THE WORLD}

The following printout is from the NETFLUX.WK1 spreadsheet included in this data package. All regional values are in $10^{6} \mathrm{Mg}$ of Carbon and were obtained by summing the individual ecosystem flux values in each region. Values of -9999.00 indicate years without data.

\begin{tabular}{|c|c|c|c|c|c|c|c|c|c|c|}
\hline \multicolumn{11}{|c|}{ Net flux of carbon from regional changes in land-use. } \\
\hline V1.0 & & & & & & & & & & \\
\hline \multirow[t]{3}{*}{ Year } & North & South and & Europe & North & Tropical & Former & China & South and & Pacific & TOTAL \\
\hline & America & Central & & Africa and & Africa & Soviet & & Southeast & Developed & FLUX \\
\hline & & America & & \multicolumn{2}{|l|}{ Middle East } & Union & & Asia & Region & $10 \wedge 6 \mathrm{Mg} \mathrm{C}$ \\
\hline 1850 & 139.20 & 22.17 & 57.04 & 3.95 & 5.61 & 36.70 & 58.28 & 27.30 & 1.83 & 352.081 \\
\hline 1851 & 140.82 & 21.87 & 57.02 & 3.95 & 6.47 & 36.72 & 58.26 & 55.73 & 1.83 & 382.670 \\
\hline 1852 & 143.78 & 21.60 & 56.99 & 3.95 & 6.60 & 36.75 & 58.25 & 67.19 & 1.84 & 396.939 \\
\hline 1853 & 146.66 & 21.35 & 56.98 & 3.95 & 6.69 & 36.77 & 58.24 & 75.42 & 1.84 & 407.887 \\
\hline 1854 & 149.47 & 21.13 & 56.95 & 3.95 & 6.76 & 36.80 & 58.23 & 81.48 & 1.84 & 416.611 \\
\hline 1855 & 152.24 & 20.93 & 56.93 & 3.95 & 6.83 & 36.82 & 58.22 & 86.09 & 1.84 & 423.852 \\
\hline 1856 & 154.99 & 20.75 & 56.91 & 3.95 & 6.86 & 36.84 & 58.20 & 89.20 & 1.84 & 429.551 \\
\hline 1857 & 157.73 & 20.60 & 56.89 & 3.95 & 6.88 & 36.87 & 58.19 & 91.60 & 1.84 & 434.549 \\
\hline 1858 & 160.46 & 20.46 & 56.87 & 3.95 & 6.90 & 36.89 & 58.18 & 93.55 & 1.84 & 439.103 \\
\hline 1859 & 163.19 & 20.33 & 56.85 & 3.95 & 6.92 & 36.91 & 58.17 & 95.18 & 1.85 & 443.348 \\
\hline 1860 & 164.51 & 19.89 & 56.82 & 3.95 & 6.93 & 36.94 & 58.16 & 96.59 & 1.85 & 445.634 \\
\hline 1861 & 168.08 & 20.68 & 56.91 & 9.06 & 8.02 & 37.01 & 58.03 & 97.32 & 1.93 & 457.036 \\
\hline 1862 & 171.81 & 20.91 & 57.02 & 10.02 & 8.18 & 37.02 & 57.88 & 97.94 & 2.05 & 462.832 \\
\hline 1863 & 175.70 & 21.02 & 57.14 & 10.89 & 8.31 & 37.04 & 57.72 & 98.47 & 2.18 & 468.469 \\
\hline 1864 & 179.73 & 21.07 & 57.28 & 11.33 & 8.41 & 37.05 & 57.56 & 98.94 & 2.33 & 473.701 \\
\hline 1865 & 184.25 & 21.11 & 57.43 & 11.72 & 8.48 & 37.06 & 57.38 & 99.36 & 2.49 & 479.288 \\
\hline 1866 & 185.90 & 20.70 & 57.60 & 12.08 & 8.53 & 37.07 & 57.19 & 99.74 & 2.65 & 481.464 \\
\hline 1867 & 187.69 & 20.30 & 57.79 & 12.41 & 8.56 & 37.07 & 57.00 & 100.10 & 2.81 & 483.731 \\
\hline 1868 & 189.62 & 19.92 & 57.98 & 12.71 & 8.59 & 37.08 & 56.81 & 100.42 & 2.95 & 486.083 \\
\hline 1869 & 191.67 & 19.55 & 58.19 & 13.00 & 8.62 & 37.09 & 56.61 & 100.72 & 3.10 & 488.542 \\
\hline 1870 & 194.47 & 19.53 & 58.64 & 13.42 & 8.64 & 37.14 & 56.29 & 101.01 & 3.22 & 492.364 \\
\hline 1871 & 197.33 & 19.47 & 52.64 & 13.66 & 8.66 & 37.15 & 55.98 & 106.05 & 10.34 & 501.271 \\
\hline 1872 & 200.24 & 19.32 & 51.86 & 13.89 & 8.68 & 37.15 & 55.68 & 107.61 & 12.52 & 506.941 \\
\hline 1873 & 203.21 & 19.25 & 51.12 & 14.11 & 8.69 & 37.15 & 55.39 & 108.73 & 14.34 & 511.979 \\
\hline
\end{tabular}

C -3 


\begin{tabular}{|c|c|c|c|c|c|c|c|c|c|c|}
\hline \multicolumn{11}{|c|}{ Net flux of carbon from regional changes in land-use. } \\
\hline V1.0 & & & & & & & & & & \\
\hline \multirow[t]{3}{*}{ Year } & North & Sonth and & Europe & North & Tropical & Former & China & South and & Pacific & TOTAL \\
\hline & America & Central & & Africa and & Africa & Soviet & & Southeast & Developed & FLUX \\
\hline & & America & & Middle East & & Union & & Asia & Region & $10 \times 6 \mathrm{Mg} \mathrm{C}$ \\
\hline 1874 & 206.23 & 19.20 & 50.41 & 14.32 & 8.70 & 37.15 & 52.20 & 109.57 & 15.07 & 512.851 \\
\hline 1875 & 210.43 & 19.16 & 49.67 & 14.52 & 8.71 & 37.16 & 51.50 & 110.25 & 15.67 & 517.076 \\
\hline 1876 & 213.02 & 19.27 & 49.09 & 14.69 & 9.79 & 37.16 & 50.96 & 110.80 & 16.16 & 520.944 \\
\hline 1877 & 215.27 & 19.70 & 48.56 & 14.85 & 9.96 & 37.16 & 50.49 & 111.20 & 16.57 & 523.776 \\
\hline 1878 & 217.19 & 20.12 & 48.08 & 15.02 & 10.08 & 37.17 & 50.06 & 111.55 & 16.94 & 526.203 \\
\hline 1879 & 218.80 & 20.51 & 47.63 & 15.16 & 10.18 & 37.17 & 49.67 & 111.86 & 17.27 & 528.245 \\
\hline 1880 & 220.08 & 20.89 & 46.08 & 15.30 & 10.26 & 37.18 & 49.30 & 112.14 & 17.57 & 528.796 \\
\hline 1881 & 221.06 & 51.16 & 45.81 & 15.45 & 10.30 & 37.18 & 48.96 & 112.40 & 17.88 & 560.193 \\
\hline 1882 & 221.74 & 59.58 & 45.57 & 15.59 & 10.33 & 37.18 & 48.63 & 112.64 & 18.19 & 569.455 \\
\hline 1883 & 222.13 & 66.36 & 45.36 & 15.73 & 10.36 & 37.19 & 47.84 & 112.87 & 18.50 & 576.341 \\
\hline 1884 & 222.23 & 71.98 & 45.18 & 15.88 & 10.39 & 37.19 & 47.61 & 113.09 & 18.81 & 582.341 \\
\hline 1885 & 220.94 & 76.74 & 44.81 & 16.09 & 10.41 & 37.19 & 47.50 & 113.30 & 19.33 & 586.297 \\
\hline 1886 & 219.48 & 79.52 & 45.34 & 16.29 & 11.71 & 37.20 & 47.39 & 113.50 & 19.84 & 590.257 \\
\hline 1887 & 217.86 & 81.50 & 45.87 & 16.49 & 11.91 & 37.20 & 47.29 & 113.70 & 20.34 & 592.149 \\
\hline 1888 & 216.08 & 83.14 & 46.41 & 16.68 & 12.06 & 37.20 & 47.20 & 113.88 & 20.82 & 593.471 \\
\hline 1889 & 214.15 & 84.51 & 46.94 & 16.87 & 12.18 & 37.20 & 47.17 & 114.07 & 21.25 & 594.329 \\
\hline 1890 & 210.02 & 85.67 & 47.58 & 17.05 & 12.28 & 37.21 & 47.14 & 114.24 & 21.66 & 592845 \\
\hline 1891 & 215.77 & 69.39 & 48.20 & 17.23 & 12.34 & 37.21 & 47.12 & 127.23 & 22.06 & 596.552 \\
\hline 1892 & 214.40 & 66.11 & 48.82 & 17.40 & 12.38 & 37.21 & 47.11 & 131.30 & 22.45 & 597.187 \\
\hline 1893 & 213.00 & 63.60 & 49.42 & 17.57 & 12.42 & 37.22 & 47.09 & 134.26 & 22.83 & 597.402 \\
\hline 1894 & 211.56 & 61.66 & 50.01 & 17.73 & 12.45 & 37.22 & 47.09 & 136.50 & 23.20 & 597.414 \\
\hline 1895 & 209.89 & 60.15 & 50.58 & 17.89 & 12.47 & 37.22 & 47.08 & 138.26 & 23.56 & 597.112 \\
\hline 1896 & 208.13 & 59.13 & 51.13 & 18.05 & 12.50 & 37.22 & 47.08 & 139.53 & 23.92 & 596.682 \\
\hline 1897 & 206.38 & 58.35 & 51.67 & 18.20 & 12.52 & 37.22 & 47.08 & 140.46 & 24.26 & 596.133 \\
\hline 1898 & 204.65 & 57.75 & 52.20 & 18.35 & 12.53 & 37.23 & 47.09 & 141.23 & 24.59 & 595.616 \\
\hline 1899 & 202.95 & 57.29 & 52.71 & 18.50 & 12.55 & 37.23 & 47.09 & 141.91 & 24.91 & 595.131 \\
\hline 1900 & 202.70 & 56.93 & 53.20 & 18.64 & 12.56 & 37.23 & 47.10 & 142.51 & 25.23 & 596.114 \\
\hline 1901 & 201.24 & 115.25 & 53.78 & 21.18 & 15.57 & 37.18 & 47.23 & 142.92 & 25.64 & 659.978 \\
\hline 1902 & 199.88 & 131.95 & 54.37 & 21.71 & 16.02 & 37.18 & 47.38 & 143.28 & 26.06 & 677.836 \\
\hline
\end{tabular}

C - 4 


\begin{tabular}{|c|c|c|c|c|c|c|c|c|c|c|}
\hline \multicolumn{11}{|c|}{ Net flux of carbon from regional changes in land-use. } \\
\hline V1.0 & & & & & & & & & & \\
\hline \multirow[t]{3}{*}{ Year } & North & South and & Europe & North & Tropical & Former & China & South and & Pacific & TOTAL \\
\hline & America & Central & & Africa and & Africa & Soviet & & Southeast & Developed & FLUX \\
\hline & & America & & Middle East & & Union & & Asia & Region & $10^{\wedge} 6 \mathrm{Mg} \mathrm{C}$ \\
\hline 1903 & 198.61 & 145.53 & 54.97 & 22.20 & 16.35 & 37.18 & 47.55 & 143.61 & 26.50 & 692.503 \\
\hline 1904 & 197.44 & 156.87 & 55.59 & 22.47 & 16.61 & 37.19 & 47.73 & 143.92 & 26.93 & 704.765 \\
\hline 1905 & 196.59 & 166.63 & 56.22 & 22.99 & 16.82 & 37.20 & 47.93 & 144.21 & 27.37 & 715.969 \\
\hline 1906 & 194.06 & 171.07 & 56.86 & 23.19 & 16.93 & 37.21 & 48.13 & 150.88 & 27.81 & 726.155 \\
\hline 1907 & 191.64 & 174.68 & 57.51 & 23.37 & 17.02 & 37.22 & 48.34 & 152.95 & 28.23 & 730.962 \\
\hline 1908 & 189.31 & 177.66 & 58.16 & 23.53 & 17.10 & 37.23 & 48.55 & 154.46 & 28.65 & 734.645 \\
\hline 1909 & 187.08 & 180.17 & 58.82 & 23.67 & 17.16 & 37.25 & 48.75 & 155.61 & 29.06 & 737.566 \\
\hline 1910 & 185.17 & 181.91 & 59.71 & 23.73 & 17.21 & 37.20 & 49.00 & 156.53 & 29.50 & 739.970 \\
\hline 1911 & 183.23 & 122.99 & 60.57 & 23.80 & 21.53 & 37.22 & 49.27 & 157.25 & 29.90 & 685.751 \\
\hline 1912 & 181.36 & 106.06 & 61.40 & 23.85 & 22.20 & 37.23 & 49.53 & 157.76 & 30.29 & 669.683 \\
\hline 1913 & 179.58 & 92.17 & 62.23 & 23.90 & 22.69 & 42.35 & 49.79 & 142.67 & 30.66 & 646.033 \\
\hline 1914 & 177.87 & 80.40 & 63.03 & 23.95 & 23.08 & 45.81 & 56.62 & 137.70 & 31.01 & 639.476 \\
\hline 1915 & 176.68 & 70.11 & 63.62 & 23.99 & 23.40 & 49.23 & 57.80 & 134.07 & 31.36 & 630.251 \\
\hline 1916 & 175.52 & 66.27 & 64.57 & 23.99 & 23.57 & 52.62 & 58.87 & 137.15 & 31.69 & 634.244 \\
\hline 1917 & 174.39 & 63.18 & 65.48 & 23.98 & 23.71 & 56.18 & 59.78 & 136.44 & 32.02 & 635.169 \\
\hline 1918 & 173.32 & 60.65 & 66.37 & 23.97 & 23.82 & 59.91 & 60.51 & 136.00 & 32.33 & 636.891 \\
\hline 1919 & 172.28 & 58.53 & 67.22 & 23.95 & 23.92 & 63.50 & 61.32 & 135.54 & 32.64 & 638.916 \\
\hline 1920 & 171.14 & 56.67 & 67.99 & 23.93 & 24.00 & 66.96 & 62.12 & 135.09 & 32.94 & 640.854 \\
\hline 1921 & 170.05 & 99.08 & 68.75 & 23.91 & 28.35 & 70.29 & 62.89 & 134.72 & 33.23 & 691.270 \\
\hline 1922 & 169.03 & 110.98 & 69.47 & 23.88 & 29.04 & 73.50 & 63.63 & 134.23 & 33.51 & 707.266 \\
\hline 1923 & 168.06 & 120.58 & 70.18 & 23.85 & 29.56 & 76.63 & 65.42 & 134.15 & 33.78 & 722.216 \\
\hline 1924 & 167.16 & 128.62 & 70.86 & 23.82 & 29.97 & 79.62 & 66.00 & 134.10 & 34.04 & 734.177 \\
\hline 1925 & 166.05 & 135.59 & 71.53 & 23.79 & 30.30 & 82.48 & 66.54 & 134.06 & 34.29 & 744.619 \\
\hline 1926 & 164.32 & 137.53 & 71.32 & 32.38 & 30.49 & 85.20 & 66.89 & 129.87 & 34.56 & 752.548 \\
\hline 1927 & 162.53 & 138.97 & 70.96 & 34.29 & 30.64 & 87.77 & 67.19 & 128.30 & 34.84 & 755.481 \\
\hline 1928 & 160.68 & 140.04 & 70.45 & 36.00 & 30.77 & 89.75 & 67.47 & 127.21 & 35.11 & 757.474 \\
\hline 1929 & 137.20 & 140.81 & 69.79 & 36.42 & 30.88 & 91.65 & 67.59 & 126.43 & 35.39 & 736.163 \\
\hline 1930 & 129.26 & 141.78 & 68.99 & 36.74 & 30.97 & 93.48 & 67.67 & 125.87 & 35.66 & 730.433 \\
\hline 1931 & 121.49 & 152.91 & 68.06 & 37.36 & 35.33 & 95.23 & 67.75 & 125.51 & 35.93 & 739.575 \\
\hline
\end{tabular}

C - 5 


\begin{tabular}{|c|c|c|c|c|c|c|c|c|c|c|}
\hline \multicolumn{11}{|c|}{ Net flux of carbon from regional changes in land-use. } \\
\hline V1.0 & & & & & & & & & & \\
\hline \multirow[t]{3}{*}{ Year } & North & South and & Europe & North & Tropical & Former & China & South and & Pacific & TOTAL \\
\hline & America & Central & & Africa and & Africa & Soviet & & Southeast & Developed & FLUX \\
\hline & & America & & Middle East & & Union & & Asia & Region & $10 \times 6 \mathrm{Mg} \mathrm{C}$ \\
\hline 1932 & 113.88 & 155.91 & 67.00 & 37.91 & 36.02 & 96.88 & 67.81 & 125.27 & 36.20 & 736.884 \\
\hline 1933 & 106.41 & 158.25 & 65.82 & 38.42 & 36.55 & 97.49 & 67.86 & 125.08 & 36.46 & 732.342 \\
\hline 1934 & 99.04 & 160.09 & 64.52 & 38.90 & 36.96 & 98.04 & 70.90 & 124.95 & 36.71 & 730.111 \\
\hline 1935 & 91.87 & 161.54 & 61.97 & 39.41 & 37.30 & 98.51 & 71.57 & 124.84 & 36.98 & 723.987 \\
\hline 1936 & 84.11 & 163.15 & 59.41 & 39.89 & 37.49 & 98.76 & 72.14 & 137.29 & 37.24 & 729.494 \\
\hline 1937 & 76.45 & 164.94 & 56.87 & 40.35 & 37.65 & 98.75 & 72.57 & 141.54 & 37.50 & 726.601 \\
\hline 1938 & 65.72 & 166.51 & 54.33 & 40.79 & 37.78 & 98.83 & 72.94 & 144.70 & 37.75 & 719.331 \\
\hline 1939 & 58.52 & 167.94 & 51.79 & 41.21 & 37.89 & 98.98 & 73.29 & 147.12 & 37.99 & 714.727 \\
\hline 1940 & 50.63 & 169.25 & 48.92 & 41.62 & 37.98 & 97.99 & 73.61 & 149.04 & 38.23 & 707.274 \\
\hline 1941 & 42.85 & 167.89 & 46.09 & 41.99 & 53.04 & 83.97 & 73.92 & 153.55 & 38.46 & 701.755 \\
\hline 1942 & 35.19 & 167.36 & 43.31 & 42.35 & 55.30 & 80.05 & 74.21 & 158.74 & 38.68 & 695.183 \\
\hline 1943 & 27.20 & 166.98 & 40.57 & 42.70 & 56.99 & 76.45 & 73.82 & 164.01 & 38.89 & 687.620 \\
\hline 1944 & 23.30 & 166.75 & 37.87 & 42.98 & 58.30 & 73.16 & 74.16 & 169.27 & 39.11 & 684.887 \\
\hline 1945 & 19.49 & 166.53 & 35.22 & 43.38 & 59.36 & 69.94 & 74.48 & 174.46 & 39.31 & 682.182 \\
\hline 1946 & 15.83 & 169.39 & 32.62 & 43.63 & 59.92 & 67.58 & 74.80 & 232.58 & 39.51 & 735.857 \\
\hline 1947 & 12.40 & 172.32 & 30.06 & 43.88 & 60.38 & 63.76 & 75.11 & 253.15 & 39.70 & 750.752 \\
\hline 1948 & 9.03 & 175.43 & 27.55 & 44.11 & 60.75 & 59.84 & 75.41 & 268.85 & 39.88 & 760.869 \\
\hline 1949 & 5.77 & 178.69 & 25.09 & 44.34 & 61.06 & 55.71 & 75.43 & 280.65 & 40.06 & 766.805 \\
\hline 1950 & 2.60 & 183.83 & 22.67 & 44.56 & 61.33 & 52.64 & 75.45 & 290.65 & 40.23 & 773.956 \\
\hline 1951 & -5.85 & 240.91 & 20.52 & 35.39 & 82.95 & 161.93 & 76.48 & 299.98 & 73.53 & 985.842 \\
\hline 1952 & -10.11 & 259.34 & 18.57 & 33.62 & 86.28 & 180.74 & 77.56 & 308.54 & 82.66 & 1037.192 \\
\hline 1953 & -14.01 & 274.26 & 16.81 & 31.82 & 88.76 & 198.21 & 78.66 & 280.82 & 90.05 & 1045.376 \\
\hline 1954 & -17.61 & 286.51 & 15.24 & 29.60 & 90.71 & 214.67 & 79.78 & 276.87 & 91.89 & 1067.658 \\
\hline 1955 & -20.90 & 296.82 & 13.85 & 27.39 & 92.29 & 230.79 & 100.19 & 275.15 & 92.97 & 1108.555 \\
\hline 1956 & -23.91 & 302.82 & 12.63 & 26.71 & 93.16 & 247.98 & 105.27 & 270.03 & 93.57 & 1128.269 \\
\hline 1957 & -26.64 & 307.73 & 11.58 & 26.06 & 93.86 & 264.63 & 109.81 & 264.88 & 93.84 & 1145.748 \\
\hline 1958 & -29.12 & 311.79 & 10.69 & 25.43 & 94.44 & 280.73 & 113.84 & 253.96 & 93.87 & 1155.625 \\
\hline 1959 & -31.34 & 316.97 & 9.96 & 24.84 & 94.92 & 207.28 & 117.28 & 249.89 & 93.73 & 1083.519 \\
\hline 1960 & -32.55 & 321.13 & 10.49 & 23.64 & 95.34 & 204.21 & 121.64 & 246.76 & 93.12 & 1083.794 \\
\hline
\end{tabular}

C -6 


\begin{tabular}{|c|c|c|c|c|c|c|c|c|c|c|}
\hline \multicolumn{11}{|c|}{ Net flux of carbon from regional changes in land-use. } \\
\hline V1.0 & & & & & & & & & & \\
\hline \multirow[t]{3}{*}{ Year } & North & South and & Europe & North & Tropical & Former & China & South and & Pacific & TOTAL \\
\hline & America & Central & & Africa and & Africa & Soviet & & Southeast & Developed & FLUX \\
\hline & & America & & Middle East & & Union & & Asia & Region & $10^{2} 6 \mathrm{Mg} \mathrm{C}$ \\
\hline 1961 & -33.60 & 430.49 & 7.93 & 23.33 & 129.92 & 193.47 & 125.74 & 247.13 & 92.44 & 1216.852 \\
\hline 1962 & -34.50 & 463.32 & 7.93 & 23.04 & 135.24 & 190.52 & 129.59 & 248.60 & 91.74 & 1255.481 \\
\hline 1963 & -35.26 & 489.04 & 7.99 & 22.74 & 139.22 & 187.22 & 133.24 & 258.05 & 91.00 & 1293.252 \\
\hline 1964 & -35.89 & 512.19 & 8.10 & 22.46 & 142.32 & 183.89 & 136.68 & 262.16 & 90.26 & 1322.175 \\
\hline 1965 & -34.85 & 531.35 & 8.46 & 22.18 & 144.85 & 180.61 & 139.92 & 265.61 & 89.50 & 1347.631 \\
\hline 1966 & -32.83 & 540.90 & 8.86 & 23.50 & 146.24 & 168.23 & 141.06 & 269.79 & 88.75 & 1354.512 \\
\hline 1967 & -30.78 & 548.79 & 9.27 & 23.90 & 147.36 & 155.91 & 143.15 & 274.14 & 87.99 & 1359.719 \\
\hline 1968 & -28.73 & 555.61 & 9.70 & 24.24 & 148.28 & 143.45 & 145.17 & 283.51 & 87.26 & 1368.497 \\
\hline 1969 & -26.66 & 566.03 & 10.14 & 24.20 & 149.06 & 132.73 & 147.20 & 288.42 & 86.28 & 1377.413 \\
\hline 1970 & -25.08 & 574.31 & 8.21 & 24.45 & 149.73 & 99.03 & 147.96 & 292.79 & 85.32 & 1356.713 \\
\hline 1971 & -22.97 & 521.78 & 6.25 & 24.66 & 184.53 & 84.46 & 117.74 & 284.51 & 48.69 & 1249.639 \\
\hline 1972 & -20.55 & 510.77 & 4.10 & 24.86 & 190.04 & 70.32 & 114.30 & 283.49 & 37.18 & 1214.501 \\
\hline 1973 & -18.83 & 502.08 & 1.76 & 25.06 & 194.18 & 56.70 & 110.93 & 333.02 & 27.44 & 1232.349 \\
\hline 1974 & -15.29 & 495.02 & -0.75 & 25.26 & 197.43 & 51.82 & 107.81 & 348.63 & 23.46 & 1233.406 \\
\hline 1975 & -11.48 & 489.16 & -3.60 & 25.46 & 200.09 & 49.16 & 104.65 & 360.00 & 20.21 & 1233.635 \\
\hline 1976 & -8.01 & 488.75 & -6.10 & 25.62 & 201.60 & 48.92 & 101.46 & 453.97 & 17.50 & 1323.714 \\
\hline 1977 & -4.71 & 488.91 & -8.77 & 25.76 & 202.82 & 45.65 & 98.20 & 487.02 & 15.13 & 1350.012 \\
\hline 1978 & -1.56 & 489.16 & -11.58 & 25.88 & 203.84 & 42.16 & 94.97 & 510.98 & 12.99 & 1366.848 \\
\hline 1979 & 1.43 & 497.14 & -14.54 & 25.99 & 233.70 & 38.00 & 91.48 & 528.90 & 11.02 & 1413.130 \\
\hline 1980 & 5.67 & 501.83 & -19.54 & 26.01 & 238.69 & 34.24 & 84.11 & 543.26 & 8.80 & 1423.075 \\
\hline 1981 & -9999.00 & 509.63 & -9999.00 & -9999.00 & 256.24 & 33.40 & -9999.00 & 620.81 & -9999.00 & -9999.00 \\
\hline 1982 & -9999.00 & 512.33 & -9999.00 & -9999.00 & 261.24 & 31.38 & -9999.00 & 645.29 & -9999.00 & -9999.00 \\
\hline 1983 & -9999.00 & 512.81 & -9999.00 & -9999.00 & 265.19 & 29.96 & -9999.00 & 661.89 & -9999.00 & -9999.00 \\
\hline 1984 & -9999.00 & 548.55 & -9999.00 & -9999.00 & 267.79 & 28.34 & -9999.00 & 673.93 & -9999.00 & -9999.00 \\
\hline 1985 & -9999.00 & 559.95 & -9999.00 & -9999.00 & 269.92 & 26.07 & -9999.00 & 683.09 & -9999.00 & -9999.00 \\
\hline 1986 & -9999.00 & 564.18 & -9999.00 & -9999.00 & 318.45 & -9999 & -9999.00 & 691.36 & -9999.00 & -9999.00 \\
\hline 1987 & -9999.00 & 590.23 & -9999.00 & -9999.00 & 326.57 & -9999 & -9999.00 & 687.85 & -9999.00 & -9999.00 \\
\hline 1988 & -9999.00 & 595.39 & -9999.00 & -9999.00 & 332.71 & -9999 & -9999.00 & 691.13 & -9999.00 & -9999.00 \\
\hline 1989 & -9999.00 & 578.81 & -9999.00 & -9999.00 & 337.54 & -9999 & -9999.00 & 694.87 & -9999.00 & -9999.00 \\
\hline
\end{tabular}

C -7 


\begin{tabular}{||l|l|l|l|l|l|l|l|l|l|l||}
\hline \multicolumn{2}{|l|}{ Net flux of carbon from regional changes in land-use. } & & & & & & & \\
\hline V1.0 & & & & & & & & & \\
\hline Year & North & South and & Europe & North & Tropical & Former & China & South and & Pacific & TOTAL \\
\hline & America & Central & & Africa and & Africa & Soviet & & Southeast & Developed & FLUX \\
\hline & & America & & Middle East & Union & & Asia & Region & 10 ( $\mathrm{Mg}$ C \\
\hline 1990 & -9999.00 & 573.41 & -9999.00 & -9999.00 & 341.50 & -9999 & -9999.00 & 698.79 & -9999.00 & -9999.00 \\
\hline
\end{tabular}

C -8 


\section{APPENDIX D}

REPRINT OF PERTINENT LITERATURE 
Reprinted with permission from Ecological Monographs

Volume 53, Number 3, September 1983

Note: The carbon fluxes and land cover change values shown is this article have been revised. The revised data are contained within the digital data distriubted with this document. 


\title{
CHANGES IN THE CARBON CONTENT OF TERRESTRIAL BIOTA AND SOILS BETWEEN 1860 AND 1980: A NET RELEASE OF $\mathrm{CO}_{2}$ TO THE ATMOSPHERE ${ }^{1}$
}

\author{
R. A. Houghton, J. E. Hossie. Ano J. M. Melillo \\ The Ecosystems Center. Marine Biological Laboratory. \\ Woods Hole. Messechusetts 02343 USA \\ B. MoOre \\ Complex Systems Research Center. University of New Hampshire. \\ Durham. New Hampshire 03824 USA \\ AND \\ B. J. Peterson, G. R. Shaver, and G. M. Woodwell \\ The Ecosystems Center. Morine Biological Laborarory. \\ Woods Hole. Massachusetts 02543 USA
}

\begin{abstract}
Changes in land use over the past two centuries bave caused a significant release of $\mathrm{CO}_{2}$ to the atmosphere from the terrestrial biota and soils. An analysis of this retease is based on amounts of orpanic carbon within an ecosystem following changes such as harvest of forests; it is also based on rates of changes. such as conversion of forest to agrialture. deduced from agricultural and forestry statistics. A model is used to calculate the net amount of carbon stored or released each year by the biok and soils of 69 regional ecosystems. Some $\alpha$ the changes. such as afforestation. the erown of harvested forests, and buildup of soil oranic matter. result in a storage of carton: others. such as barvest of foreses and increase in pasture and agricularal areas, result in a loss $\alpha$ carbon to the atmosphere.

Acconding to this analysis. there has been a net release of earbon from terrestrial ecosystems worldwide since at least 1860 . Until -1960 , the annual release was greater than release of arbon from fossil fuets. The total net release of carbon from terrestrial ecosystems since 1860 is estimated to have been $180 \times 10^{13} \mathrm{~g} 12$ range of estimates is $135-228 \times 10^{13} \mathrm{~g}$. The estimated net retease of carbon in 1980 was $1.8-4.7 \times 10^{43} \mathrm{~g}$; for the $22 \mathrm{yr}$ since 1958 the relense of $\mathrm{C}$ was $38-76 \times 10^{13} \mathrm{~g}$. The ranges reflect the differences among various extimates of forest biomass, soil carbon, and aericularnl clear. ing. Improvements in the data on the ciearing of tropieal forests alone would reduce the range of escimates for 1900 by almost $60 \%$.

Estimates of the ocher major terms in the global carbon budget. the atmospheric increase in $\mathrm{CO}_{2}$. the fossil fuel release of $\mathrm{CO}_{2}$, and the oceanic uptake of $\mathrm{CO}_{3}$. are all subject to uncerainties. The combined errors in these estimates are large enough that the globel carton budget appears balanced if the low estimate for the biotic release of carbon given above is used $\left(1.8 \times 10^{13} \mathrm{~g}\right.$ released in 1980$)$ with the higher estimates of oceanic uptake. If higher estimates for biotic release are used. then the carton budget does not balance. and the estimates of oceanic uptake or of other factors require revision.
\end{abstract}

Key words: agricultural expansion: utmospheric $\mathrm{CO}_{2}$; carbon: curbon cycle: $\mathrm{CO}_{2}$ ideforestation: globel carbon budget: land use: soil carbon loss; lerrestrial biour.

\section{INTRODUCTION}

The concentration of atmospheric $\mathrm{CO}$, has increased by $15-25 \%$ over the past 100 yr. The evidence for this rise comes primarily from the continuous record stared in 1958 at Mauna Loa. Hawaii (Pales and Keeling 1965. Keeling et al. 1976b). and from a parallel record at the South Pole (Keeling et ai. 1976u). Evidence for changes before 1958 comes from direct measurements of oceanic water masses of known age (Brewer 1978. Then and Millero 1979) and from models (Keeling 1973a. Oeschger et al. 1975). The trend of the atmospheric record suggests that the rate of increase of the $\mathrm{CO}$, content of air is accelerating, and concen-

t Manuscript received 17 December 1981: revised 29 July 1982: accepted 7 September 1982. trations will reach $=\$ 500 \mu L L$ by 3030 (Keeling and Bacastow 1977). This concentration is approximately double the level of $1903 \mathrm{AD}$. A doubling in atmospheric $\mathrm{CO}_{2}$ is expected to cause a global warming of $2^{\circ}-$ $4^{\circ} \mathrm{C}$, with climatic warming greater at the poles than at the equator (Manabe and Stouffer 1979. Manabe and Wetherald 1980). The resultant problems of such climate modification for humans will include a shift in the area and the distribution of arable lands and a rise in sea level of as much as $5 \mathrm{~m}$ over $100-200 \mathrm{yr}$ (MacDonald 1978, Woodwell et al. 1979. Council on Environmental Quality 1981 l).

There is no doubt about the size of the changes in atmospheric $\mathrm{CO}_{2}$ since 1958 . but there is some argument about the causes of the changes. Not only is additional $\mathrm{CO}$, released to the atmosphere from the 
burning of fossil fuets. but $\mathrm{CO}_{3}$ is also released by the clearing of forests. Much of the $\mathrm{CO}_{2}$ is taken up by the oceans, and some is also stored in plants. The annual changes in these components of the carbon cycle are given by:

$$
A=F-S=L \text {. }
$$

where $A=$ the annual increase in atmospheric $\mathrm{CO}_{2}$. now 1.0-1.5 $\mu \mathrm{LL}$ or $2-3 \times 10^{23} \mathrm{~s}$ of $C_{\text {: }} F=$ the annual release of carbon as $\mathrm{CO}_{2}$ from combustion of fos. sil fuels, currently $S-6 \times 10^{13} 8$ of $C_{i} S=$ the average annual aet movement of carbon as $\mathrm{CO}_{2}$ into the cceans. estimated as 1.8-2.4 $\times 10^{13} \mathrm{~g}$ of $\mathrm{C}(37-10 \%$ of $F)$ : and $L=$ the net exchange of $C$ between the atmosphere and the land surface, estimated as between -2 and $+20 \times 10^{13} \mathrm{~g} / \mathrm{yr}$, due to changes in the amount of carbon heid in the biou and soils."

The terms are not known with equal precision. The increase in the atmosphere $(A)$ and the release from fossil fuets $(F)$ are thought to be knowe within <15\%; the net transfer to the oceans $(S)$ is less cerrain. as is the role of the biok $(L)$. Our objective is to refine the estimates of the biotic change.

Cerrain analyses of the causes of the increase in atmospheric $\mathrm{CO}_{1}$ (Bacastow and Keeling 1973. Keeting 1973a. Machta 1973, Oeschger ex al. 1979) assumed that the only aet source of $\mathrm{CO}_{2}$ was from the combustion of fossil fuels. The amount of $\mathrm{CO}_{2}$ not absorbed by the oceans or observed in the atmosphere was assumed to aceumulate on land. The rate of storage of carbon by the terrestrial biota was assumed to increase as the conceatration of $\mathrm{CO}_{3}$ increased. These assumptions may not have been warranted, as calculations indicate the bion is currently releasing additional casboa to the atmosphere rather than storing carbon (Bolin 1977. Woodwell and Houghton 1977. Woodwell et al. 1978). Furthermore, the amount of carbon released through conversion of forested had to agriculare and through the increased harvest of forests is believed to be larger than any increase in storage of arbon stimulated by higher levels of $\mathrm{CO}_{2}$ (Bolin 1977. Woodwell and Houghton 1977. Woodwell et al. 1978).

Recent analyses of the global carbon cycle based on oceanic models have not included a net fux of carbon from the biota (Siegenthaler and Oeschger 1978. Broecker et al. 1979). As in the earlier oceanic models. the role of the biota has been determined by difference: $L=F-S-A$. There is no model that calculates directly the net carbon lux between the atmosphere and tertestrial ecosystems, although several attempts have been made to calculate the exchange over various time intervals (Bolin 1977, Revelle and Munk 1977. Woodwell and Houghton 1977, Woodwell et al. 1978, Hampicke 1979, Seiler and Crutzen 1980). In this paper we describe a model that does calculate directly that part of the net terrestrial fiux $(L)$ due to changes in the use of land worldwide. The types of land-use change considered are harvest of forests. clearing of nawral ecosystems for agriculture, and af. forestation. We believe that these are responsible for the most imporant changes in the amount of carton held on land.

In the next sections. we describe the model and identify the sources of information and the data used. We then present the results of several tests of alternative assumptions and dan and discuss the implications of these and ocher results of the modelling for the global arbon cycle and for future research.

\section{a Model of Exchanges of Terrestrial Carbon With the atmosphere}

The reduction in the mass of regetation that accompanies most distutbances of tertestrial ecosystems is obvious. Harvest of wood from a forest and repiace. ment of trees with crops are examples of reduction in standing stocks. Less obvious but well documented is the reduction in soil carbon that also follows many kinds of disturbances. These generally rapid losses of carton are followed by slower aceumulations of carbon. as trees regrow and soils build up again after harvest or after abandonment of agriculture.

The most important part of this model is a curve that describes changes in carbon stocks that follow disturbance. In one form of the curve. harvest of a forest (Fig. 1) reduces forest biomass: some of the carton is transferted to domestic or commercial use where it decays at various rates. some is transferted to soil as slash and dead rooks. and some remains as
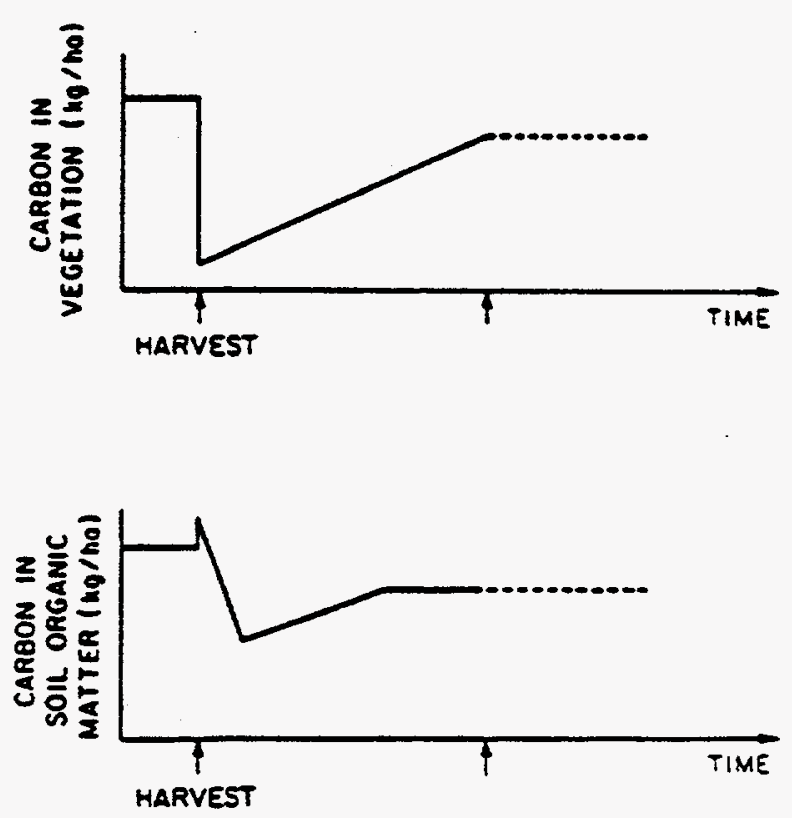

Fig. 1. Idealized curves describing the changes per unt land area in the caton content of vegetation and soll. foilowing harvest of a forest. The second artows indicate whe:" the forest has regrown suficiently to be harvested again. The dashed line shows one of several responses. 
living material. Soil organic matter declines for several years after harvest until regrowth of vegetation results in a net accumulation of soil carbon. Response curves for afforestation are similar in form to the curves describing regrowth of forests following harvest. In another form of the curve. clearing of land for agricuiture (Fig. 2) reduces carbon in both vegetation and soils. with no subsequent change unless the fields are abandoned.

An analysis of the net flux of carbon between terrestrial systems and the atmosphere must account for the changes over time that follow disturbance: changes in vegetation. soil. and products removed from the forest. Each of these components regrows or decays at various rates. The rates of buildup and decay, as well as the rates of disturbance. vary with geographic regions and with vegetation types. Time lags associated with growth and decay make an annual flux calculated in the model very different and more realistic than a fiux calculated on the basis of one year's ciearing and harvest. The large number of different quanities that must be accounted for each year requires a computer model.

The model we have developed is a bookkeeping. not a process. model (Moore et al. 1981). It keeps track of the yearly changes of carbon in terrestrial ecosystems (including both biota and soils). Theoretically. the model can contain 10 geographic regions (Appendix 1) with up to 14 types of ecosystems (Table I). including agroecosystems. within each region. In the analyses reported here. the model contained 69 eco. systems based upon a regional breakdown of Whitta. ker and Likens (1973) world classification scheme.

For each ecosystem included. the model describes the response of vegetation and soils to different kinds of disturbances. The direction and magnitude of the responses are different for each ecosystem. although
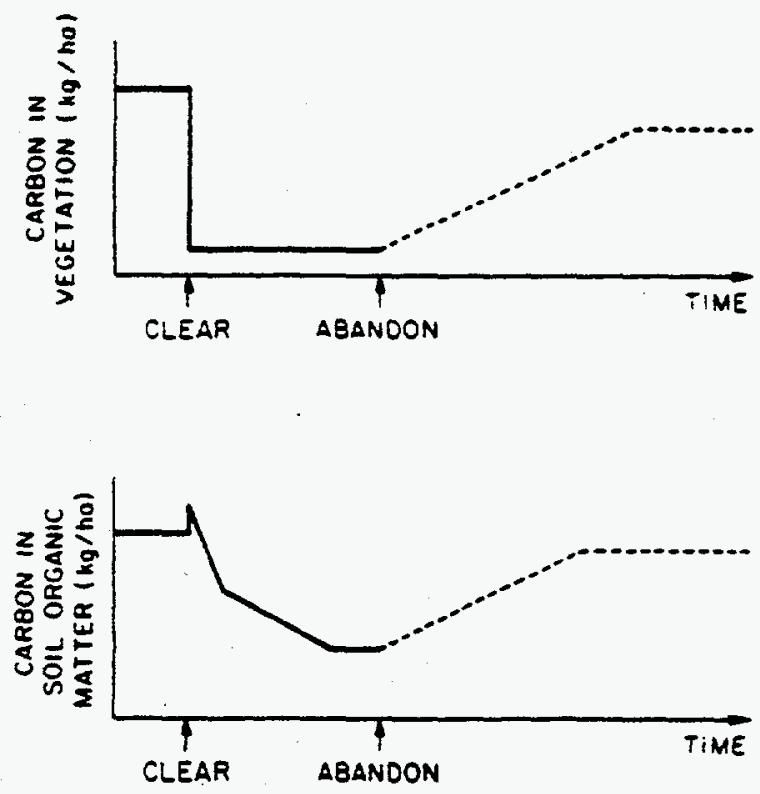

Fic. 2. Idealized curves describing the changes per unit land area in the carbon content of vegetation and soil following clearing of forest for apriculture. The dashed line shows the changes that occur if agriculural land is abandoned.

the form of each response curve is the same recific response curves were developed for both veyetation and soil for each ecosystem and for the following six kinds of disturbance: harvest of a forest followed by regrowth. clearing of natural ecosystems for cultiva. tion. clearing of natural systems for pasture, abandonment of cultivated land. abandonment of pasture. and afforestation. By use of these curves the model keeps track of the area. age. and carbon content of each disturbed ecosystem. It also computes the oxidzition of fuelwood and wood protucts removed from forest

Table 1. Areas (in 10. hal of ecosystems in each region of the wortd in 1700

\begin{tabular}{|c|c|c|c|c|c|c|c|c|c|c|}
\hline & $\begin{array}{l}\text { North } \\
\text { America }\end{array}$ & Europe & USSR & $\begin{array}{l}\text { Pacific } \\
\text { devel- } \\
\text { oped }\end{array}$ & China & $\begin{array}{c}\text { Latin } \\
\text { America }\end{array}$ & $\begin{array}{c}\text { North } \\
\text { Africa } \\
\text { and } \\
\text { Middle } \\
\text { East }\end{array}$ & $\begin{array}{c}\text { Tropical } \\
\text { Africa }\end{array}$ & $\begin{array}{c}\text { South } \\
\text { Asia }\end{array}$ & $\begin{array}{c}\text { South. } \\
\text { east } \\
\text { Asia }\end{array}$ \\
\hline $\begin{array}{l}\text { Tropical moist forest } \\
\text { Tropical seasonal forest } \\
\text { Temperate evergreen forest } \\
\text { Temperate deciduous forest } \\
\text { Boreal forest } \\
\text { Tropical woodland and shrubland } \\
\text { Temperate woodland and shrubland } \\
\text { Tropical grassland } \\
\text { Temperate grassland } \\
\text { Tundra and alpine meadow } \\
\text { Desert scrub } \\
\text { Swamp and marsh } \\
\text { Cultivated land } \\
\text { Pasture land }\end{array}$ & $\begin{array}{r}0 \\
0 \\
236 \\
157 \\
394 \\
0 \\
229 \\
0 \\
568 \\
343 \\
0 \\
0 \\
3 \\
4\end{array}$ & $\begin{array}{r}0 \\
0 \\
85 \\
65 \\
35 \\
0 \\
45 \\
0 \\
88 \\
27 \\
0 \\
0 \\
67 \\
75\end{array}$ & $\begin{array}{r}0 \\
0 \\
108 \\
148 \\
750 \\
0 \\
132 \\
0 \\
175 \\
336 \\
504 \\
0 \\
33 \\
53\end{array}$ & $\begin{array}{r}166 \\
0 \\
32 \\
49 \\
0 \\
20 \\
0 \\
497 \\
0 \\
0 \\
118 \\
0 \\
5 \\
24\end{array}$ & $\begin{array}{r}14 \\
0 \\
40 \\
81 \\
0 \\
0 \\
0 \\
0 \\
723 \\
0 \\
145 \\
0 \\
29 \\
83\end{array}$ & $\begin{array}{r}500 \\
175 \\
26 \\
112 \\
0 \\
285 \\
347 \\
74 \\
497 \\
0 \\
0 \\
0 \\
7 \\
37\end{array}$ & $\begin{array}{r}19 \\
0 \\
19 \\
0 \\
0 \\
0 \\
0 \\
90 \\
0 \\
0 \\
979 \\
0 \\
20 \\
54\end{array}$ & $\begin{array}{r}426 \\
481 \\
0 \\
0 \\
0 \\
451 \\
0 \\
459 \\
0 \\
0 \\
406 \\
0 \\
44 \\
187\end{array}$ & $\begin{array}{r}12 \\
134 \\
0 \\
0 \\
0 \\
189 \\
0 \\
182 \\
0 \\
0 \\
0 \\
0 \\
53 \\
7\end{array}$ & $\begin{array}{r}215 \\
38 \\
0 \\
0 \\
0 \\
0 \\
0 \\
123 \\
0 \\
0 \\
0 \\
0 \\
4 \\
2\end{array}$ \\
\hline & 1934 & 487 & 2239 & 911 & 1115 & 2060 & 1181 & 2454 & 577 & 382 \\
\hline
\end{tabular}

D - 5 
ecosystems. The computed net fux of carbon between the atmosphere and the land for any year depends on the balance of the factors affecting the loss and accumulation of carton on land. Our approach is thus to account for changes in net carbon storage through time rather than to model processes such as photosynthesis and respiration.

The annual flux of carbon between terrestrial ecosystems and the atmosphere was calculated by the model from $1700 \mathrm{AD}$ to the present. Because of the time lags inherent in the response of terrestrial ecosystems to disturbance and hence in the calculations of the model. we allowed the computations to proceed for $160 \mathrm{yr}$ before considering the results. The results reported here are the annual net flux in 1980. the total net flux for the period of the atmospheric $\mathrm{CO}_{2}$ record from Mauna Loa (1958-1980). and the total net flux for the 120-yr period for which estimates of fossil fuel use exist. $1860-1980$.

\section{The Data For the MOdel: A Summary INCLUDING DOCUMENTATION AND ASSUMPTIONS}

In the following pages we describe the assumptions and data used in the model. These, along with alternative sets of data and assumptions. are used in the next two sections (Use of the Model and Testing Data and Assumptions) to construct 16 tests of the sensitivity of the model.

\section{Parameters that define the response curves}

In the response curves (Figs. 1 and 2), we use the data of Whittaker and Likens (1973) for the mass of carbon in undisturbed ecosystems (Tables 2 and 3 ).

Secondary forests, those that develop following harvest or abandonment of agriculture. reach $75 \%$ of their undisturbed biomass in the model. In those locations where nonforest vegetation is transformed to agriculture. the biomass recovers to the original nonforest mass after abandonment. In the model. all forests can be harvested after 50 yr of regrowth. Where abandonment of agricultural land leads to a vegetation other than forest. we have used periods of $50 \mathrm{yr}$ or less (Table 3).

When forests are harvested and allowed to regrow. some vegetation is left on the site at harvest. This dead vegetation. including stumps, roots. branches. leaves. and other debris, is assigned to the pool of carbon in soil. The mass of carbon in the dead plant material left on site is calculated from harvest data summarized by Weck and Wiebecke (1961) for different forest types (Table ?).

When natural systems are transformed to agriculture, a similar assignment of vegetation is needed. When forests are transformed to agriculture. $33 \%$ of the carbon is transferred to the soil, while in the trans. formation of nonforest systems. $50 \%$ is transferted.
We use Schlesinger's data $(1977,1983)$ for the carbon in the upper $1 \mathrm{~m}$ of soil in undisturbed systems (Tables 2 and 3 ).

Between 25 and $50 \%$ of the litter and humus may be lost from a forest after harvest or other severe distur. bance. The net loss of humus. termed the "assart effect" in the boreal forest (Tamm and Pettersson 1969). has also been observed in the temperate forests of the northeastern United States (Morey 1942. Sarz and Huttinger 1950. Trimble and Lull 1956. Covington 1977) and in tropical forests (Popenoe 1957. Cunningham 1963. Nye and Greenland 1964. Zinke et al. 1978. Aw. eto 1981 ). Decomposition of the soil organic matter is enhanced by increased temperature and moisture con. tent of the soil surface (Lutz and Chandler 1946. Moller 1947. Hart 1961. Ovington 1968. Witkamp 1971. Marks and Bormann 1972). Furthermore. the addition of carbon to soil, in the form of litter and small roots. is reduced during the first years following harvest. In the model. the carbon in soil to a depth of $1 \mathrm{~m}$ decomposes following harvest to $65 \%$ of the original soil carbon content in tropical forests. to $50 \%$ in temperate. and $1085 \%$ in boreal forests. The loss is smaller after harvest of secondary forests (Table 2). The time to reach the minimum soil carbon value was estimated from the references given above.

The cultivation of formerly forested land also enhances decomposition because more of the soil is exposed to oxidation. In the model. clearing and cultivation result in an initial rapid loss of the organic carbon followed by a slower loss as a resuh of continued titlage over time (Fig. 2. Table 3) (Salter et al. 1941. Puhr and Worzella 1952. Giddens 1957. Haas et al. 1957. Nye and Greenland 1960). In regions of deser scrub that are irrigated. there is actually an increase. rather than a decrease. in the organic carbon content of soils (Schlesinger 1982). This increase is included in the model (Table 3).

We assume that the recovery of soil carbon of abandoned permanent agriculture and of harvested forests in the tropics is similar to the pattern of recovery of soil carbon during the fallow cycle of shifting cultivation (Zinke et al. 1978. Aweto 1981 ). In the model the carbon content of soils took 50 yr to retum to of the original level in the tropics (Reed 1951 ) and is $90 \%$ of the original level in the temperate and boreal regions (Covington 1977). For nonforest systems the soil carbon retumed to $100 \%$ of its original level during the period of recovery.

We have been unable to document any changes in carbon storage that occur when natural lands are transformed to pasture. We assume that new pastureland comes from grassiands and that the carbon does not change. In Latin America. where forests have been cleared recently for cattle grazing. we assume that tropical forest soils lose $=\mathbf{2 5 \%}$ of their carbon when converted to pasture I Krebs 1975. Buringh 1983. J. M. Street. personal coinmunication). 
TABle 2. Data used in the Terrestrial Carbon Model to define the changes in the carbon in vegetation and soils during harvest and regrowth of a forest.

\begin{tabular}{|c|c|c|c|c|c|}
\hline & $\begin{array}{l}\text { Tropical } \\
\text { moist } \\
\text { forest }\end{array}$ & $\begin{array}{l}\text { Tropical } \\
\text { seasonal } \\
\text { foresi }\end{array}$ & $\begin{array}{l}\text { Temperate } \\
\text { evergreen } \\
\text { forest }\end{array}$ & $\begin{array}{l}\text { Temperate } \\
\text { deciduous } \\
\text { forest }\end{array}$ & $\begin{array}{l}\text { Boreal } \\
\text { forest }\end{array}$ \\
\hline $\begin{array}{l}\left.\text { Carbon in vegetation of undisturbed forests } 110^{6} \mathrm{~g} / \mathrm{ha}\right)^{*} \\
\text { Carbon in vegetation of secondary forests }\left(10^{6} \mathrm{~g} / \mathrm{ha}\right) \\
\text { Carbon in live vegetation left on site }\end{array}$ & $\begin{array}{l}200 \\
150\end{array}$ & $\begin{array}{l}160 \\
120\end{array}$ & $\begin{array}{l}160 \\
120\end{array}$ & $\begin{array}{l}135 \\
100\end{array}$ & $\begin{array}{l}90 \\
68\end{array}$ \\
\hline it time of harvest ( $10^{6} \mathrm{gha}$ ) & 0 & 0 & 0 & 0 & 0 \\
\hline $\begin{array}{l}\text { Time required for forest to regrow } \\
\text { before harvested again }(y r)\end{array}$ & 50 & so & so & 50 & $\leq 0$ \\
\hline Curbon in voils of undisturbed forests $\left(10^{6}\right.$ ghat & 117 & 117 & 134 & 134 & 206 \\
\hline Curbon in soils of secondary forests $110^{6}$ gihal & 88 & 88 & 120 & 120 & 185 \\
\hline Carbon in wood harvested $\left(10^{*} g /\right.$ ha $)$ & 43 & 23 & 30 & 30 & 12 \\
\hline $\begin{array}{l}\text { Carbon in dead plant material left } \\
\text { in soil at time of harvest ( } 106 \text { gha })\end{array}$ & $\begin{array}{l}157 \ddagger \\
107 \$\end{array}$ & $\begin{array}{r}137 \\
97\end{array}$ & $\begin{array}{r}130 \\
90\end{array}$ & $\begin{array}{r}105 \\
70\end{array}$ & $\begin{array}{l}78 \\
56\end{array}$ \\
\hline $\begin{array}{l}\text { Minimum carbon content in soil following harvest } \\
110^{\circ} \mathrm{g} \text { has }\end{array}$ & 76 & 76 & 67 & 67 & 175 \\
\hline $\begin{array}{l}\text { Time required for soil carbon to reach } \\
\text { minimum following harvest (yr) }\end{array}$ & $s$ & $s$ & 10 & 10 & is \\
\hline $\begin{array}{l}\text { Time required for soil carbon to go from } \\
\text { minimum to level of secondary forest (yr) }\end{array}$ & 15 & 15 & 40 & 40 & 35 \\
\hline
\end{tabular}

- Whittaker and Likens (1973)

- Schlesinger (1977).

Undisturbed forests.

$\S$ Secondary forests.

\section{Staristics on land use and rates of han'est}

We obtained data on rates of change in land use and rates of harvest from economic. agricultural, statistical. and historical sources: we concentrated on the global scale when possible and at the regional or national scale when global summaries did not exist.

The values we used for the analysis are given in Appendix 2. and the sources of information we consulted are presented below.

Hariest of nood. - Rates of wood removal priot to 1946 for Europe. European Russia, and North America were based primarily on reviews by Hough ( 1878 . 1880. 18821. the International Institute of Agriculture (II,A) (1922). Zon and Sparhawk (1923). Ilvessalo and Jalava (1930). Reynolds and Pierson (1942). the Food and Agricultural Organization of the United Nations (FAO 1946). Tsepiyaev (1965). Mitehell (3975). and Clawson (1979). For the developing countries prior to 1946. we calculated wood harvest on the basis of per capita rates of fuelwood use given by Openshaw (1974). Arnold and Jongma (1978), and Fleuret and Fleuret 11978). Fuelwood accounts for nearly $80 \%$ of total roundwood production in these countries and for $>50 \%$ of the world's total wood harvest (Openshaw 1978).

Since 1946 the FAO has conducted four World Forest Inientories (FAO 1948. 1955, 1960. 1966) and published annual statistics (FAO 1946-1979) on production reported as volumes of coniferous and nonconiferous wood. The harvested coniferous wood is assigned to temperate evergreen or boreal forests. and nonconiferous wood to temperate deciduous. tropical moist. or tropical seasonal forests. When several for- est types are present, the assignment is made on the basis of area. In the model there is no harvest of fuelwood from woodlands and shrublands: thus. all wood is harvested from one of the five major forest types.

Volume of wood is converted to mass of carbon using densities of coniferous and nonconiferous woods (Yearbook of Forest Products [FAO 1946-1979): carbon content is $45 \%$ of dry mass. The final conversion factors are: $1 \mathrm{~m}^{3}$ coniferous wood $=280 \mathrm{~kg} \mathrm{C}: 1 \mathrm{~m}^{3}$ nonconiferous wood $=340 \mathrm{~kg} \mathrm{C}$.

Decuy of wood remoied from a forest. - Harvested wood products are oxidized over rime and must be included in our estimates of carbon flux to the atmosphere. All fuelwood is oxidized within I yr of harvest. white indusirial wood decays over 10 or 100 yr. The fraction of wood assigned to each category was obtained from the World Bank (1978): paper and paper products $(10 \mathrm{yr})$ represented $=40 \%$ of the industrial wood. while lumber and longer-lasting products 1100 yr) were $=60 \%$ of the total (Appendix 2).

Based on studies of decomposition. we have assigned to various rates of decay fractions of the biomass cleared from ecosystems after conversion to agriculture (Table 3). Forest biomass decays within 10 $y r$ in tropical forests (John 1973) and within $100 \mathrm{yr}$ in temperate zone forests (Swift et al. 1979). Biomass of nonforest systems decays within $10 \mathrm{yr}$.

Areas cleared for crops. - We calculated rates of clearing for agriculture from changes in the area of cropiand given by Grigg (1974). Robertson (1956). the International Institute of Agricuiture (1922. 1939). Production Yeurbooks (FAO 1949-1978), and the 
TABLE 3. Data used in the Tertestrial Carbon Model to define the changes in the earbon in vegetation and soils during the transformation of a natural ecosystem to agriculture. during cultivation. and following abandonment. Blank spaces indicate that in the model the ecosystems were not cleared for apgicuiture.

\begin{tabular}{|c|c|c|c|c|c|c|c|c|c|c|c|c|}
\hline & $\begin{array}{l}\text { Tropical } \\
\text { most } \\
\text { forest }\end{array}$ & $\begin{array}{l}\text { Tropical } \\
\text { seasonal } \\
\text { forest }\end{array}$ & $\begin{array}{l}\text { Temperate } \\
\text { evergreen } \\
\text { forest }\end{array}$ & $\begin{array}{l}\text { Temperate } \\
\text { Jecaduous } \\
\text { forest }\end{array}$ & $\begin{array}{l}\text { Boreal } \\
\text { fores: }\end{array}$ & $\begin{array}{l}\text { Tropical } \\
\text { woodland } \\
\text { shrubland }\end{array}$ & $\begin{array}{l}\text { Tem: } \\
\text { perate } \\
\text { woodland } \\
\text { shrubland }\end{array}$ & $\begin{array}{c}\text { Tropreal } \\
\text { grass. } \\
\text { land }\end{array}$ & $\begin{array}{l}\text { Temperate } \\
\text { grass. } \\
\text { land }\end{array}$ & $\begin{array}{l}\text { Tundra } \\
\text { upene } \\
\text { meadow }\end{array}$ & $\begin{array}{l}\text { Desen } \\
\text { serse }\end{array}$ & $\begin{array}{l}\text { Swamp } \\
\text { narsh }\end{array}$ \\
\hline $\begin{array}{l}\text { Cerbon in vegetation of undisturbed } \\
\text { ecosystems : to enat" }\end{array}$ & $: \infty$ & 160 & 160 & 135 & 90 & $=$ & 9 & 18 & $\cdot$ & 3 & : & \\
\hline $\begin{array}{l}\text { Carbon in vegetation of "re. } \\
\text { covered" eeosystems } 110 \text { thal }\end{array}$ & 150 & 130 & 120 & 100 & 68 & $\because$ & $9 ?$ & 18 & $\cdot$ & & $:$ & \\
\hline Carbon in erops 1100 y & s & s & $s$ & $s$ & $s$ & $s$ & $\therefore$ & ? & 3 & & 1 & \\
\hline $\begin{array}{l}\text { Time required for an abandoned sys- } \\
\text { tem to "recover" (yr) }\end{array}$ & so & 50 & .0 & so & 9 & 25 & so & : & 10 & & $: 0$ & \\
\hline $\begin{array}{l}\text { Cartion in sols of undisturbed eca } \\
\text { systems } 110 \% \text { has" }\end{array}$ & 117 & 117 & 134 & 134 & $2 \infty$ & 69 & $\infty$ & 42 & 189 & 200 & \$8 & \\
\hline $\begin{array}{l}\text { Carton in sois of "recovered" sys. } \\
\text { tems } 110 \text { ghat }\end{array}$ & 88 & 88 & 120 & $1=0$ & 185 & 69 & 69 & 4: & 189 & & $s$ & \\
\hline $\begin{array}{l}\text { Fraction of carbon in regetation left } \\
\text { dead in sal at ume of cleanns }\end{array}$ & 0.33 & 033 & 0.33 & 033 & 0.33 & 0.50 & 0.50 & $0 . \$ 0$ & 0.90 & & $0 \leq 0$ & \\
\hline $\begin{array}{l}\text { Fraction of carbon in vegetalion as- } \\
\text { jigned to decay pools after clear. } \\
\text { ing }\end{array}$ & & & & & & & & & & & & \\
\hline lyr & 0.40 & 0.40 & 0.40 & 0.40 & 0.40 & 0.40 & 0.40 & 0.50 & 0.50 & & 30 & \\
\hline $10 \mathrm{yr}$ & 0.37 & 0.27 & 0.20 . & 0.20 & 0.20 & 010 & 0.10 & 0.8 & 0.0 & & 0.0 & \\
\hline $100 y$ & 00 & 0.0 & 0.07 & 0.07 & 0.07 & 0.0 & 0.0 & 0.0 & 0.0 & & Do & \\
\hline $\begin{array}{l}\text { Carbon content of soll after intial. } \\
\text { rapid change followng ctearng } \\
\text { 110 g hal }\end{array}$ & 70 & 70 & 80 & $\$$ & 160 & 41 & 41 & $2 !$ & 113 & & 80 & \\
\hline $\begin{array}{l}\text { Mirumum carbon content of sal in } \\
\text { culuvated system } 110^{\circ} \text { gihal }\end{array}$ & $\mathbf{s}$ & 58 & 67 & 67 & 103 & 34 & 34 & :1 & 9 & & $8^{-}$ & \\
\hline $\begin{array}{l}\text { Time required for imudi. rapid } \\
\text { change in sail carton follownse } \\
\text { cleanng (yri) }\end{array}$ & 3 & 3 & 15 & 15 & 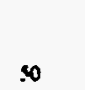 & 3 & is & 3 & is & & ! & \\
\hline $\begin{array}{l}\text { Time required for carbon in sail to } \\
\text { reach minimum value dunns culti. } \\
\text { vation tyr) }\end{array}$ & 15 & is & 30 & 30 & so & 15 & 30 & 15 & 30 & & 10 & \\
\hline $\begin{array}{l}\text { Time required for sosl carton to } \\
\text { reuch "recovered" levet in an } \\
\text { dbandoned system (yr) }\end{array}$ & 15 & 15 & 40 & 40 & 35 & 15 & 45 & Is & 4 & & 10 & \\
\hline
\end{tabular}

- Whitraker and Likens (1973).

: Schiesinger (1977).

Canadian and United States Census Bureaus. These sources cover the period from $\approx 1800$ for all geographical regions except North Africa-Middle East. Latin America. and Tropical Africa. For these three regions we have estimated areas of cropland before 1950 on the basis of population (McEvedy and Jones 1978). Rates of clearing within each region were as. signed to ecosystems. using as references Grigg (1974). Robertson (1956). Whittlesey (1964), and Küchler (1964).

Despite the importance of agriculture. we found that the agricultural data were surprisingly sparse. The First World Agriculture Census was not conducted until 1930 (by the International Institute of Agriculture (1939]): it covered 37 of 200 countries. The remaining 16.3 countries. representing $>50 \%$ of the world's land area and almost $75 \%$ of its population. had never taken an agricultural census. After 1946. the FAO collected and issued statistics on the area of land in various uses. Data reported in the Production Yearburiks of the FAO (1949-1978) still suffer from inappropriate application of definitions, as the agricultural data on reumed questionnaires often refer only to crops that reach national or international markets (Ajtay et dl. 1979).

Assignment based on comparisons of areas of nalural vegetation with mapped world agricultural regions introduces uncertainty, particularly in assignment of dates to the conversions.

Afforestation. -Changes in total afforested area over time were obtained from Zon and Sparhawk 1,9:31. and the FAO's European Timber Trends and Pro. pects 1950 to 2000 (1976). Because species of pines are most commonly planted. all afforested land has been classified as temperate evergreen forest. In those regions where afforestation has been important ( Europe USSR, and China), the ecosystem selected for affore:tation was temperate zone grasslands. 
Areas cleured for grazing. - We have used the FAO Production Yeurbooks to estimate rates of land clearing for pasture since 1960 . There is no reliable source for rates before 1960. so for our first estimate we used the per capita use of grazing land. Such estimates are questionable because populations of nomadic herdsmen have declined during the last century (Grigg 1974). Therefore, in the model. pastures are usually derived from grasslands. and the transformation leads to no change in carbon storage. The only exception occurs in Latin America. where there is good evidence that forests at the edge of the Amazon forest have been cleared in recent years for grazing.

\section{Starting the model: areas of different ecosystems in 1700}

The total areas of different ecosystems in 1700 (Table (I) were approximated by distributing the world vegetation types of Whittaker and Likens (1973) among regions on the basis of Küchler's map (1964) of natural vegetation. These areas of natural ecosystems were then reduced by the areas of agriculture in 1700 , estimated on the basis of population (McEvedy and Jones 1978).

It is important to note that calculations of carbon flux with the model do not include forests or other ecosystems that are undisturbed. We assume that these systems are in a steady state and that there is no net change in their carbon content. Therefore. the total area of natural ecosystems is not important for this analysis. Errors in area of various ecosystems only affect the analysis when rates of clearing require more land than is available or when land is cleared from ecosystems on the basis of their relative areas.

This assumption of steady state means that our anal$y$ sis is incomplete to the extent that undisturbed systems are not in steady state. For example, the soils of previously glaciated areas may still be accumulating :arbon (Billings et al. 1982). Also the primary production of terrestrial systems may have increased more than respiration, as a result of the higher concentrations of $\mathrm{CO}_{2}$ in the atmosphere. We believe these changes in carbon stocks to be small relative to the changes analyzed here.

\section{USE OF THE MOdEL}

\section{Estimating the values for early years}

The model is a useful tool in revealing certain inconsistencies in the values chosen. In eariy model runs. it was found necessary to adjust rates of clearing. the types of vegetation cleared. or the original distribution of vegetation types in 1700 in order to make the data internally consistent. Similarly, the harvest of forests required the internal consistency of areas of forests assigned in 1700. wood harvest through time, rates of wood harvest per hectare, and rates of forest resrowth. The interaction of different types of data in

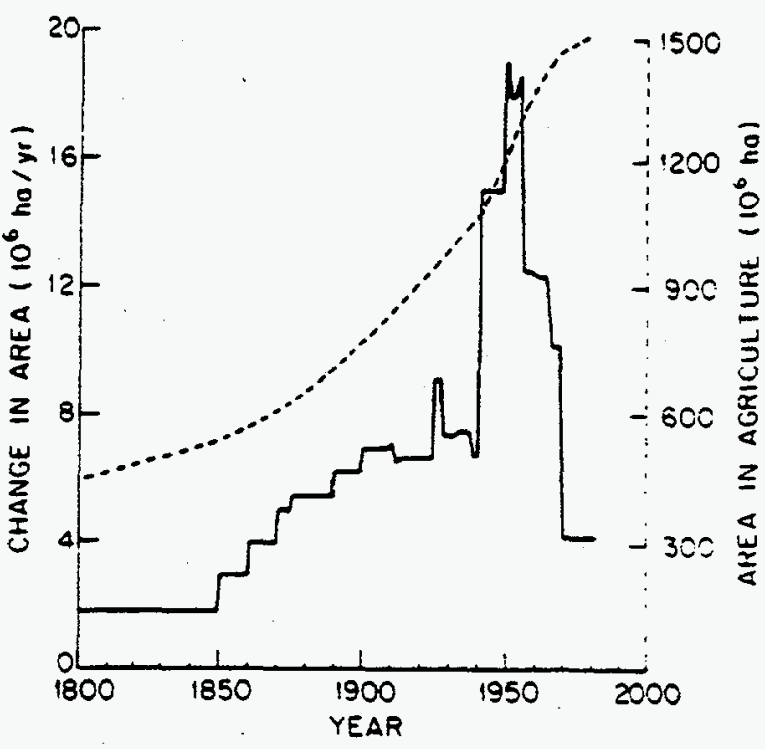

FIG. 3. Worldwide area in agriculture $(---$,$) and rate$ of clearing (-). The data for the period after 1945 were derived from the Production Yearbnoks (F.4O 1949-1978).

these ways imposed constraints on input data. Thus. some of the data that were clearly wrong have been taken out of our calculations, but inherent uncertainties still remain in the original data.

\section{Assessing the values for recent years}

Data on areas of vegetation and rates of clearing and harvest in the 18 th and early 19 th centuries were difficult to obtain. The difficulty with data since 1950 is not their availability but the multiplicity of sources and the variability. We present below three independent estimates of recent agricultural expansion in the tropics and include each of them in a separate analysis. In general, the data used in each analysis were the same until 1950 (Appendices 2. 3. and 4).

1. The low estimate (FAO Production Yearbooks).-We used the Production Yearbooks of the Agricultural Division of the FAO to obtain rates of agricultural expansion for each region of the world (Appendix 3). The data on expansion. summarized for the world in Fig. 3 (solid line), show an irregular rise in the rate of expansion until about 1950 . followed by a sharp drop that appears to be continuing through the present. The results (Fig. 4) show a net release of carbon that parallels the rate of change in agricultural area. Over the 120 yr period since 1860 , the net release of carbon from the tertestrial biota and soils was $184 \times$ $10^{13} \mathrm{~g}$ (Table 4). The peak release of carbon was in $1955\left(3.22 \times 10^{15} \mathrm{~g}\right)$ : in 1980 the net release was $1.82 \times$ $10^{15} \mathrm{~g}$.

2. The high estimate (Myers). - An independent estimate of rates of clearing of tropical forests has been offered by Myers (1980a. b). However. it is difficult to determine whether the clearing Myers described has 


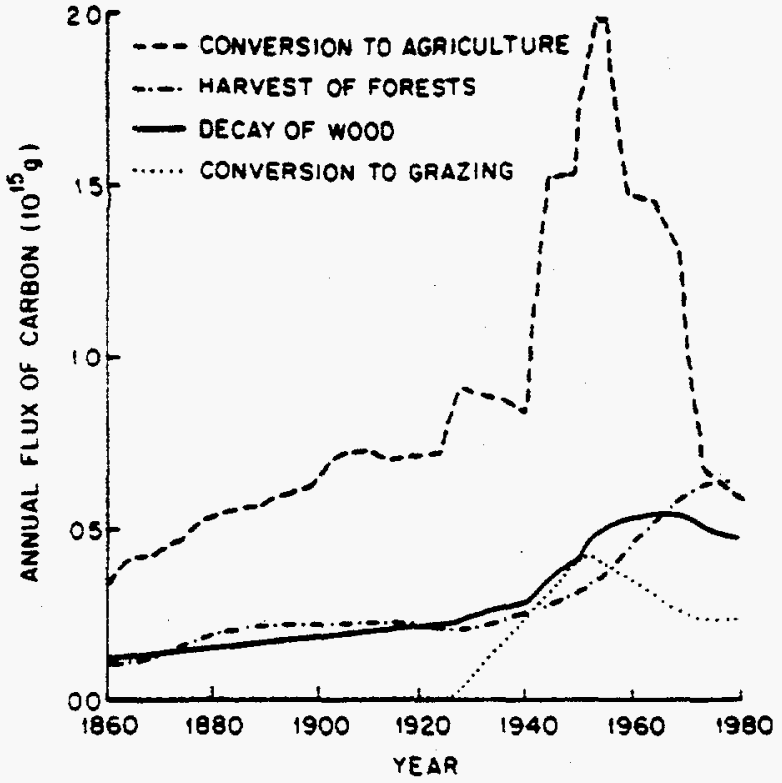

Fig. 4. Analysis based on the Production Yearbooks of the FAO (1949-1978). The curves show the net fiux to the atmosphere as a result of the clearing and cultivation of agricuitural land. harvest and regrowth of forests. oxidation of wood removed from forests. and the clearing of land for pasture.

been permanent and whether it includes the clearing of secondary forests as well as primary forests. Myers (1980b) states that much of the clearing of tropical forests. even by traditional shifting cultivators. is now permanent due to increased population density. As a result of discussions with Myers, we estimate that onethird of the cleared forests grows back to secondary forests in $50 \mathrm{yr}$. That was also the fraction recently estimated by Lanly and Gillis (1980) to regrow for Latin America.

Most of the data used for this estimate (Appendix 4) were the same as those used in the previous analysis (Appendix 3) except for the period 1965-1980 in the tropics (Latin America. North Africa-Middle East. Tropical Africa. South Asia, and Southeast Asia).

Over the 120-yr period between 1860 and 1980. the total release of carbon based on the use of the Myers data was similar to the resuits using the FAO data. The total was $185 \times 10^{25} \mathrm{~g}$. Between 1970 and 1980 , however, the results were appreciably different (Fig. 5, Table 4). More carbon was released in the Myers estimate than in the FAO estimate from each of the major processes. and the total net flux of carbon in 1980 was $4.70 \times 10^{15} \mathrm{~g}$.

We are not able to judge the accuracy of either Myers estimates of deforestation or the FAO tables of arable land and permanent cropland. Several authors have to some degree confirmed the FAO results, by noting the reduced rate at which new lands are being transformed to agriculture (Brown 1981, Bart

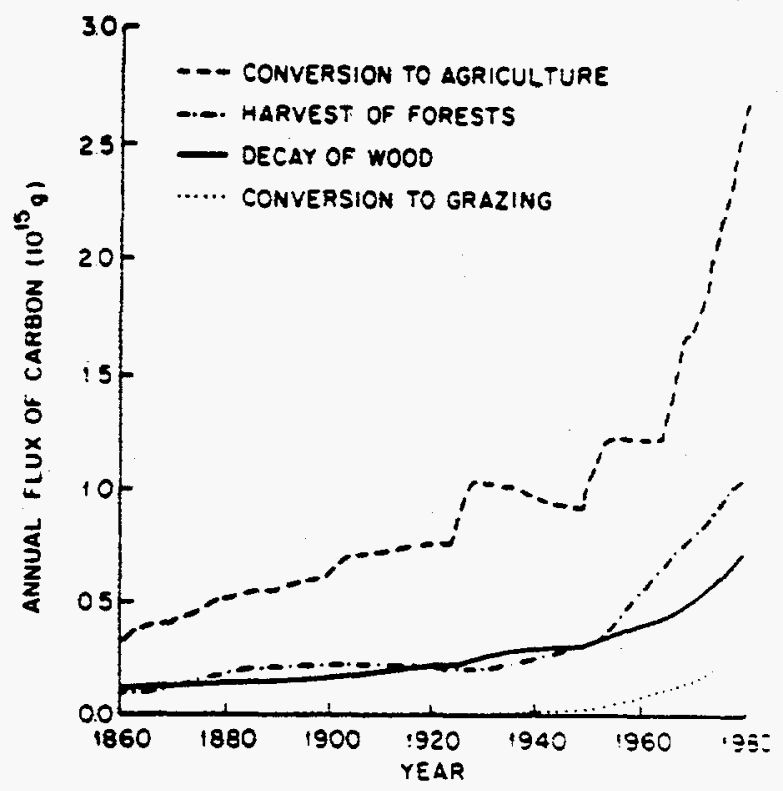

Fic. S. Analysis based on the data of Myers $11980 \mathrm{a}$. in The curves show the net flux of carbon to the atmosphere as a result of the clearing and cultivation of agricultural land. harvest and regrowth of forests. oxidation of wood harvested or cleared from forests, and the elearing of land for pasture

1982). On the other hand, the FAO statistics may not include clearing of tropical forests by the landless because such changes are not officially recognized by many governments. These changes are included in Myers estimates. We believe that these two sets of daca offer contrasting high and low estimates of land clearing.

3. An estimate based on population.-A third set of data was developed by assuming that the rate of agricultural expansion since 1950 has been proportional to the rate of growth of populations in the tropical regions. Reports of the United States Department of Agriculture (1965, 1970) have shown that increased food production in developing nations has been achieved, in part. by increased crop yields and, in par. by claiming new land for agriculture. The fraction of the increased food production due to expansion of agricultural area averaged $=60 \%$ for these regions. This fraction was used to adjust the rates of agriculturat clearing calculated on the basis of per capita use of cropland (Appendix 2). The population-based rates were computed only after 1946 ( 1860 for South Asia) and only for the five tropical regions: for other regions and times. the data were the same as used in the first analysis.

According to the population-based analysis. there has been a continuous net release of carbon from the terrestrial biota and soils in response to disturbance since 1860 and, probably, much longer (Fig. 6). Between 1860 and 1980 the net release of carbon to the 
atmosphere was $180 \times 10^{13} \mathrm{~g}$; in $1980 \mathrm{it}$ was $2.6 \times 10^{\mathrm{ls}}$ 8 (Table 4).

The carbon fux estimated in this analysis falls be. tween those from the FAO and Myers-based analyses. and it is not clear which estimate is most accurate. We describe the results of the population-based analysis here to illustrate details of model results and to provide a framework for further tests of assumptions and data (see Testing Data and Assumption).

The harvest of forests releases nearfy the same amount of carton per unit area as the clearing of land for agriculture. and during the 120yr period before 1980 , about twice as much land was harvested as was transformed to agriculure. However, harvested for. ests regain carbon as they regrow; the vegetation and soil of regrowing forests accumulated $182 \times 10^{1 \mathrm{~s}} \mathrm{~g}$ from the atmosphere since 1860 and $2.4 \times 10^{\text {is }} \mathrm{B}$ in 1980 . Agricultural lands generally are not abandoned and. as previously discussed. usually continue to lose rather than accumulate carbon. Thus. the net flux of carbon to the atmosphere as a result of transforming natural systems to agricultural land was greater than the net fux from harvest and regrowth of forests ( $101 \times$ $10^{15}$ vs. $34 \times 10^{15} \mathrm{~g}$ since $1860 ;$ Fig. 6). In 1980 the net flux of carton from agricultural expansion was neariy twice that from harvest and regrowth $\left(1.58 \times 10^{\text {ts }} \mathrm{vs}\right.$. $0.90 \times 10^{\text {is }} \mathrm{g}$; Table ).

Soils accounted for about one-third of the net flux of carbon in 1980 (Table $)$, and since 1860 their contribution has been $=72 \times 10^{15} \mathrm{~g}$. Oxidation of wood and wood products other than fuelwood released $32 \times$ $10^{15} 8$ of $C$ since 1860 and accounted for about onefifth of the flux in 1980 (Tables 4 and $\$$ ).

According to these analyses other changes in land use. such as clearing of forest for pasture and the abandonment of agricultural lands. were less important than the expansion of agriculture or the harvest of forests (Tables 4 and 5 ). The results can also be presented regionally, and it is immediately seen that not all regions show the same pattern of carbon fux as the global summary (Fig. 7 . In both North America and Europe. for example. there has been a net accumulation of carbon in forests in recent years. but that accumulation is small relative to the net releases from tropical tegions and small in the global accounting.

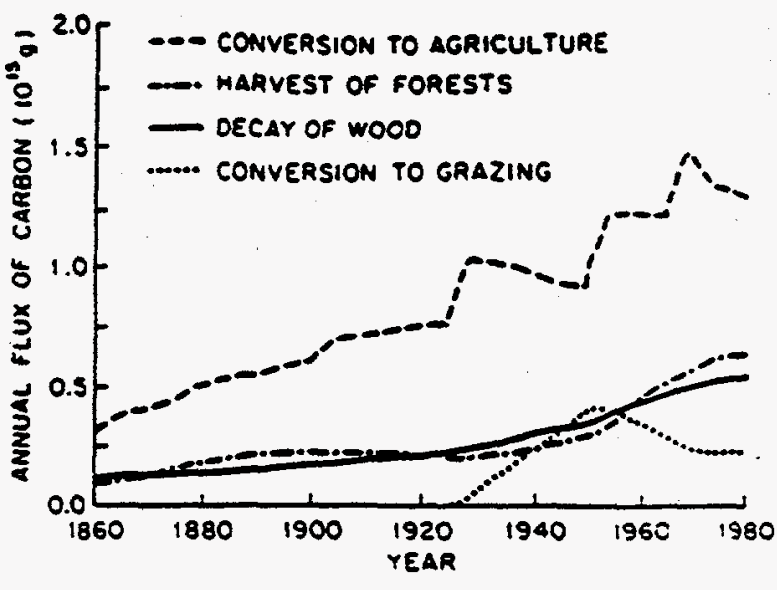

Fic. 6. Analysis based on popubtion dath. The errves show the net thux of earton to the atmosphere as a result of the clearing and cultivation of agricultural land. harvest and regrowh of forests. oxidation of wood removed from forests. and the clearing of land for pasture.

\section{Testing Data and assumptions}

The three analyses presented above give a range of $1.8-4.7 \times 10^{\text {ts }} \mathrm{g}$ for the net flux of carbon to the atmosphere in 1980 . They vary due to large uncertainties in rates of land clearing for agriculture. Are there uncertainties in other paraneters large enough to extend this rage? We have addressed this question by substituting contrasting sets of data and contrasting assumptions in separate analyses. The number of potential combinations of variables is large, and a complete analysis of all possibilities is not feasible. Furthermore, we have only one or two values for many parameters from the literature, so that a strict sensitivity analysis with probability distributions or standard errors for each parameter would be arbitrary. Finally. for those parameters for which there are several estimates. for example, estimates of tropical forest biomass. we thought it more important to test the exiremes separately. To collapse all the estimates into a single number with a standard error would bide the effect of individual sources of data on the cakulated flux of carbon.

In the following sections we report various tests of data and assumptions: each test is an alternative to the

TABLE 4. Summary of results of the low, high, and intermediate (population-based) analyses.

\begin{tabular}{|c|c|c|c|c|c|c|c|c|c|}
\hline \multirow[b]{3}{*}{ Basis of estimate } & & & \multicolumn{7}{|c|}{ Annual net release in 1980} \\
\hline & \multicolumn{2}{|c|}{ Total net release } & \multirow[b]{2}{*}{$\begin{array}{c}\text { All } \\
\text { processes }\end{array}$} & \multirow{2}{*}{$\begin{array}{l}\text { Agricul- } \\
\text { tural } \\
\text { dearing }\end{array}$} & \multirow{2}{*}{$\begin{array}{l}\text { Harvest } \\
\text { and } \\
\text { regrownh } \\
\text { of foresis }\end{array}$} & \multirow{2}{*}{$\begin{array}{l}\text { Oxidation } \\
\text { of wood } \\
\text { removed } \\
\text { from site }\end{array}$} & \multirow{2}{*}{$\begin{array}{l}\text { Abandon- } \\
\text { ment of } \\
\text { agriculure }\end{array}$} & \multirow[b]{2}{*}{$\begin{array}{l}\text { Affores- } \\
\text { tation }\end{array}$} & \multirow{2}{*}{$\begin{array}{l}\text { Clearing } \\
\text { for } \\
\text { pasture }\end{array}$} \\
\hline & $\begin{array}{r}1860 \\
1980\end{array}$ & $\begin{array}{l}1958- \\
1980\end{array}$ & & & & & & & \\
\hline & \multicolumn{9}{|c|}{ Net carbon release $\left(10^{15} \mathrm{~g}\right)$} \\
\hline $\begin{array}{l}\text { 1. FAO }(1949-1978) \\
\text { 2. Myers }(19806.6) \\
\text { 3. Population }\end{array}$ & $\begin{array}{l}184 \\
185 \\
180\end{array}$ & $\begin{array}{l}51.9 \\
69.6 \\
57.3\end{array}$ & $\begin{array}{l}1.82 \\
4.70 \\
2.61\end{array}$ & $\begin{array}{l}0.59 \\
2.70 \\
1.30\end{array}$ & $\begin{array}{l}0.63 \\
1.06 \\
0.63\end{array}$ & $\begin{array}{l}0.47 \\
0.74 \\
0.56\end{array}$ & $\begin{array}{l}-0.066 \\
-0.066 \\
-0.066\end{array}$ & $\begin{array}{l}-0.039 \\
-0.039 \\
-0.039\end{array}$ & $\begin{array}{l}0.23 \\
0.31 \\
0.23\end{array}$ \\
\hline
\end{tabular}




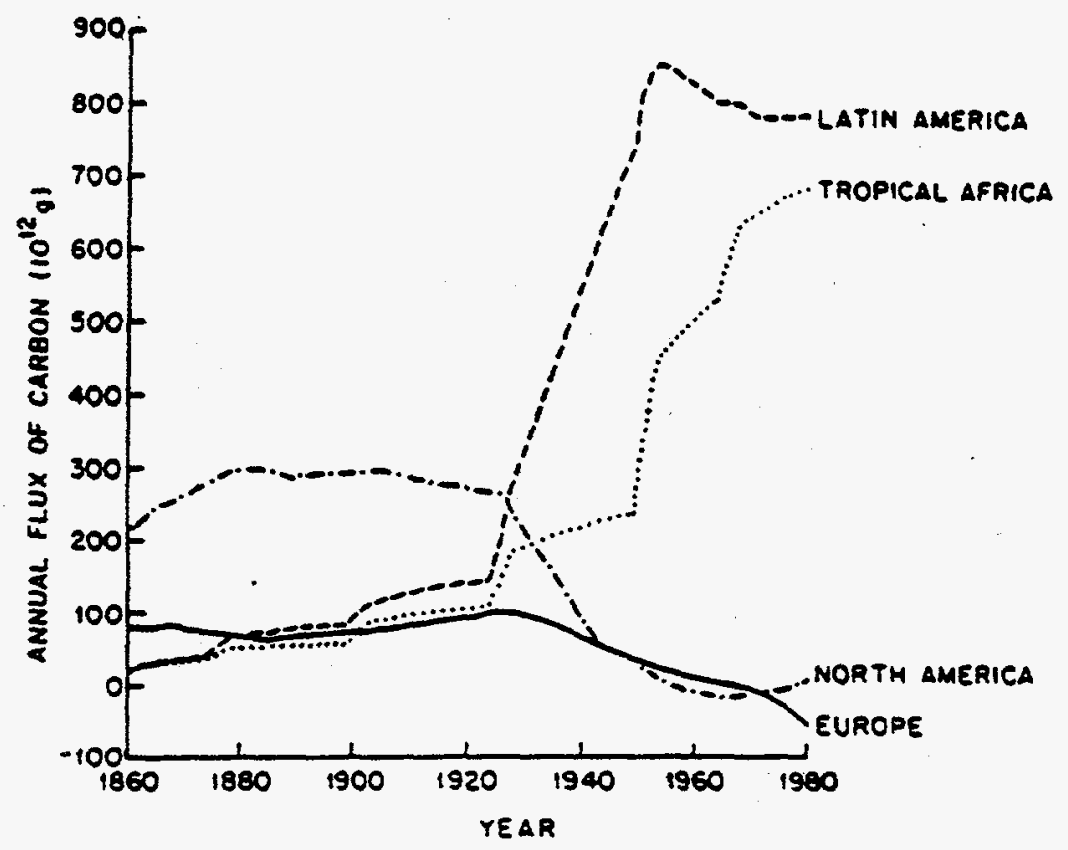

Fic. 7. Net flux of carbon to the atmosphere as a result of landuse changes and harvests in Latin America. Tropical Afric. North America. and Europe.

population-based estimate presented above. These tests have been summarized in Tables 6 and 7. The results can be used to set limits on the range of results considered possible.

\section{Tests of agricultural data}

In the analyses below we test the consequences of such uncertainties as the time at which major ctearing of forests for agriculture occurred. the types of vegetation transformed to agriculture. and the amount of carbon released from soils during cultivation.

Test 4: the time course of clearing of nutural ecosystems for agriculture. - The assumption that growth of agricultural land in the past was proportional to growh of populations has been questioned receatly by Tucker and Richards (1983). Their thesis is that major expansion of aericulural area cccurred in the mid-19th and early 20th centuries at the same time as the expansion in world trade. The timing of this major expansion is supported by isotopic evidence of increased biotic release (Freyer 1978. 1979. Stuiver 1978. Wilson 1978. Tans and Mook 1980). Recently Richards (1982) has collected statistics on the change in agricultural area for 1860-1920 and 1920-1978). for countries accounting for $=60 \%$ of worid land area. We based a iest on these dan (Appendix 5 ) but had to assume that his rates also applied to the remaning $40 \%$ of the world land area. We also added 1700-1859 rates and divided his 1920-1980 rates into shorter intervals: the rates after 1950 were always the same as our population-based analysis (Appendix 2).

The results showed a release of carbon between 1860 and 1980 of $210 \times 10^{13} \mathrm{~g} .=16 \%$ more than the popu. lavion-based analysis (Table 6). While the annual net retense was ereater than in the population-based analysis near the tum of the century, the anmual release

TABLE \$. Components of the net Aux of earbon to the atmosphere in $1980(10 \mathrm{ss})$.

\begin{tabular}{|c|c|c|c|c|c|c|}
\hline & \multicolumn{3}{|c|}{ Vegetation } & & \multirow{2}{*}{$\begin{array}{l}\text { Products } \\
\text { (Decay } \\
\text { off site) }\end{array}$} & \multirow[b]{2}{*}{ Total } \\
\hline & Bumed & $\begin{array}{l}\text { Decay } \\
\text { on site }\end{array}$ & Regowh & Soil & & \\
\hline $\begin{array}{l}\text { Clearing for agriculture } \\
\text { Harvest and regrowh } \\
\text { Clearing for pasture }\end{array}$ & $\begin{array}{l}0.38 \\
0.41 \\
0.10\end{array}$ & $\begin{array}{l}0.38 \\
1.79 \\
0.09\end{array}$ & $\begin{array}{c}0.0 \\
-1.86 \\
0.0\end{array}$ & $\begin{array}{l}0.54 \\
0.29 \\
0.04\end{array}$ & $\begin{array}{l}0.28 \\
0.27 \\
0.01\end{array}$ & $\begin{array}{l}1.58 \\
0.90 \\
0.24\end{array}$ \\
\hline \multirow[t]{2}{*}{ Tocal } & 0.89 & 2.26 & -1.86 & 0.87 & 0.56 & \\
\hline & & & \multicolumn{3}{|c|}{$\begin{array}{r}\text { Subtotal } \\
\text { Afforestation and abandonmen } \\
\text { Global net flux } 1980\end{array}$} & $\begin{array}{r}2.72 \\
-0.11 \\
2.61\end{array}$ \\
\hline
\end{tabular}


TAale 6. Summary of resuits of tests of uncerainties in the estimates for aqriculture with the Terrestrial Carbon Model. See text for details of each set of assumpoions.

\begin{tabular}{|c|c|c|c|c|c|c|c|c|c|}
\hline \multirow[b]{3}{*}{ Assumptions } & & & \multicolumn{7}{|c|}{ Annual net release in 1900} \\
\hline & \multicolumn{2}{|c|}{ Total net release } & \multirow{2}{*}{ All } & \multirow{2}{*}{$\begin{array}{l}\text { Agricul- } \\
\text { tural } \\
\text { clearing }\end{array}$} & \multirow{2}{*}{$\begin{array}{l}\text { Harvest } \\
\text { and } \\
\text { regrount } \\
\text { of forests }\end{array}$} & \multirow{2}{*}{$\begin{array}{l}\text { Oxi- } \\
\text { dation } \\
\text { of wood } \\
\text { removed } \\
\text { from site }\end{array}$} & \multirow{2}{*}{$\begin{array}{l}\text { Abandon- } \\
\text { ment of } \\
\text { apriculure }\end{array}$} & \multirow[b]{2}{*}{$\begin{array}{l}\text { Arores } \\
\text { tation }\end{array}$} & \multirow{2}{*}{$\begin{array}{c}\text { Oearing } \\
\text { for } \\
\text { pasture }\end{array}$} \\
\hline & $\begin{array}{l}1860 \\
1980\end{array}$ & $\begin{array}{l}1958- \\
1980\end{array}$ & & & & & & & \\
\hline & \multicolumn{9}{|c|}{ Net carbon release $\left(10^{13}\right)$} \\
\hline $\begin{array}{l}\text { 3. The population-based } \\
\text { andysis }\end{array}$ & 180 & 57.3 & 2.61 & 1.30 & 0.63 & 0.56 & -0.066 & -0.039 & 0.23 \\
\hline 4. Time of clearing & 210 & 62.2 & 2.79 & 1.45 & 0.63 & 0.58 & -0.062 & -0.039 & 0.23 \\
\hline $\begin{array}{l}\text { 5. 2. Forests cleared } \\
\text { b. Nonforests cleared } \\
\text { 6. Increased clearing and }\end{array}$ & $\begin{array}{l}228 \\
135\end{array}$ & $\begin{array}{l}76.1 \\
38.4\end{array}$ & $\begin{array}{l}3.49 \\
1.72\end{array}$ & $\begin{array}{l}1.97 \\
0.62\end{array}$ & $\begin{array}{l}0.63 \\
0.63\end{array}$ & $\begin{array}{l}0.76 \\
0.33\end{array}$ & $\begin{array}{l}-0.066 \\
-0.066\end{array}$ & $\begin{array}{l}-0.039 \\
-0.039\end{array}$ & $\begin{array}{l}0.23 \\
0.23\end{array}$ \\
\hline $\begin{array}{l}\text { abandonment } \\
\text { 7. Low rates of decay }\end{array}$ & 186 & 59.6 & 2.70 & 1.49 & 0.60 & 0.60 & -0.20 & -0.039 & 0.23 \\
\hline (charcoal) & 175 . & 55.6 & 2.51 & 1.16 & 0.63 & 0.59 & -0.066 & -0.039 & 0.23 \\
\hline 8. Reduced soil response & 150 & 51.0 & 2.35 & 1.01 & 0.63 & 0.56 & -0.041 & -0.039 & 0.23 \\
\hline
\end{tabular}

since then continued to increase: this contradicts the trend of the release rates obtained from most isotopic studies.

Test S: changing the ecosystems transformed to agriculture. - We constructed two extreme sets of input data to test the potential significance of misidentifying the type of vegetation cleared for agriculture. In the first we assumed that all the agricultural land in every region except North America. Europe, and the USSR came from forcsted land. In the second case we assumed that all clearing for agriculture was from nonforest ecosystems. In each case we used the same rates as reported in the population-based analysis: we changed only the relative proportions of the types of vegetation affected.

The analyses showed that between 1860 and 1980 . $228 \times 10^{13} \mathrm{~g}$ of carbon would have been released in the first test. and $135 \times 10^{13} \mathrm{~g}$ in the second (Table 6). Although these values are extreme and set an unrealistically wide range for the 120-yr release, they demonstrate how crucial it is to be able to document, even coarsely, the type of ecosystem cleared for agriculture.

Test 6: increasing the rases of clearing and abandonment. - Estimates of rates of clearing for agriculture based on changes in crop areas are net rates. the sum of clearing and abandonment. If both clearing and abandonment had occurted over the reporting period. the larger of the two would have been underestimated: the lesser would not have appeared. This use of net instead of gross rates affects the calculations because the release of carbon from forest clearing is more rapid than the storage of carbon during regrowth of a forest on abandoned land. It is also true that estimates of net change in carbon storage may be in ertor because of assumptions about the ecosystem type being changed for agricuiture. For example, in the United States in the 1800 s. midwestern grasslands were coming under cultivation. while abandoned croplands in New England were growing back to forests. The net change in carbon storage that resulted can only be estimated by calculating the change in both ecosystems.

We tested the effects of assuming higher rates of both clearing and abandonment. The only countries for which national statistics on farmland abandonment exist are the United States and certain Western Ey. ropean countries (Intemational Instiute of Agriculture 1939. Hart 1968. FAO 1976). We used an annual rate of ciearing one-third greater than that used in the population-based analysis. based on evidence that about one-third of the tropical forests cleared for agriculure in Latin America reum to forests (Lanly and Gillis 1980). We simultaneously increased the rate of abandonment so that the net change in agriculumbl land was the same as in the population-based analysis. The rescrite of this test were close to those of the population-based estimate (Table 6).

Test 7: changing the proportions of plant material in various decay pools. - It is difficult to know what happens to plant material that is cleared from land converted to permanent agriculture. If population density is high. most of that material may be used for fuelwood and oxidized within a year. If fuelwood is not in demand locally. the wood is burned during clearing or left to decay. When forests are cleared by buming, a significant frection of the ptant material may become charcoal and last for many years (Seiler and Crutzen 1980). This would cause a greater fraction of the biomass to be transferted to the longer-term decay pools than in our poputation-based test.

We tested the significance of slower rates of decay with data derived from Seiler and Crutzen (1980) (Appendix 6). In the case of permanent agriculture. the charcoal produced during land clearing is of little significance in the global catbon budget (Table 6). One of the largest contributors to charcoal formation. shift- 
ing cultivation, was not included in the analysis. but the amount of carbon stored in charcoal is small in comparison to the reductions in biomass and soil carbon that follow from an intensification of shifting cultivation (Went and Stark 1968. Clarke 1976, Scott 1977. UNESCO 1978).

Test 8: changing the response of soil carbon 10 ag: riculturul clearing. - In the population-based analysis. one-half of the carton in the top metre of soil was oxidized after land was cleared for agriculture. Although there are some agricuitural practices that increase the amount of carbon stored in soils, such as irrigation of deserts. these make up a very smail part of total agricultural land.

To test the significance of carbon lost from soils we assumed a $20 \%$ loss of earbon from all soils transferted to agriculture, as opposed to a $50 \%$ loss in the population-based analysis. The carbon originally in the regetation of these lands was oxidized as it was for the population-based analysis.

This assumption resulted in a net exchange of carbon over the last 120 yr that was one of the low estimates. $150 \times 10^{15} 8$ instead of 180 in the population-based estimate (Table 6). It is important to determine the changes in soil carbon that accompany various methods of cultivation.

\section{Tesis of data on harvest}

The results of the population-based estimate showed that the harvest of forests for timber and fuelwood has been less important in releasing $\mathrm{CO}_{2}$ into the atmo sphere than the clearing of land for agriculture (Fig. 6). There is a possibility. of course, that the daca used have been inaccurate or that assumptions made in constructing the model are wrong. In the following section we examine several questions about our handling of the information on the harvest and recovery of forests.

Test 9: doubling the world harvest of wood. - Sev. eral studies have concluded that the FAO data suffer from inconsistent definitions, irregular records, and biased dala (Persson 1974, Openshaw 1978. Myers 1980 b). The volume of wood removed from forests can be two to three times greater than that reported to the FAO. Openshaw (1974) found this to be true in Tanzania. Thailand, and Gambia. We assumed in this test that the volume of wood removed from forests woridwide was double that of the populacion-based estimate. The increased volume could have been obtained by doubling the area of forests cut each year. Since there were several regions where the area of forest was just barely able to supply the harvest called for in the population-based analysis. we chose instend to double the efficiency of wood removed per hectare. In tropical moist forests and temperate deciduous forests. we increased the efficiency of wood removal by 50\% rather than $100 \%$ and enlarged the area harvested because the removal rate was already more than half of the live biomass in those forests. In the three other forest types we doubled the removal of wood per hectare. In brief. this test increased world harvest of wood by 100\%: most of the increase came from more effi. cient use of the forest rather than from harvesting of a larger area.

The results differed little from those of the popula. tion-based estimate (Table 7 ). There was a greater release from decay in 1980 because more harvest products were being oxidized. The net release from the forests was less, however, because the greater effciency of wood removal left less dead plant material to decay in the forest.

Test 10: assuming the residual orgnic matter follow. ing harvest is live. - In the population-based estimate and in other cests we assumed that all the biomass remaining after harvest was dead and left to decay. This assumption is unrealistic. but the variability of harvesting methods in various countries makes it dif. ficult to assign this remaining biomass to live, dead. or damaged categories. We have tested the importance of this assumption in a test where all the material not harvested remained as living vegetation. The efficiencies of wood removal per hectare and the harvest rates were identical to those used in the population-based estimate. We did not change the time required for forest regrowth. although forests thinned to one-half of their standing stock probably recover to their former biomass more rapidly than forests starting with no live biomass.

The resules (Table 7) suggest that whether the biomass left on site after harvest is living or dead makes little difference to the long-term earbon balance.' A greater release of $\mathrm{CO}_{2}$ from dead and decaying vegetation is balanced in the calculations of the model by a higher uptake of regrowing vegetation.

Test 11: allowing complete recoveny of harvested forests. - In most of the tests when primary forests were harvested. regrowh was to secondary forests whose biomass and soil carbon were 75-907 of those in the original forest (Table 2). In the model. primary forests were cut only when there was no secondary forest available. As rates of forest harvest increased over time and as forest land became agricultural land. there was always some additional cutting of primary forests. but most harvests were of secondary forests. In a few regions. however. the rate of harvest decreased. yet forests that had "regrown" were maintained by the model at $75 \%$ of their original carbon content. The long-term net flux of carbon as a result of harvest and regrowth, therefore, was not zero but an amount potentially equal to $25 \%$ of the biomass and soil carton in all regrown forests.

To test the significance of this artificial restriction. we ran a test in which the carbon content of regrown forests was allowed to reach that of primary forests. This $100 \%$ recovery of vegetation and soils lowered the net release of carbon from harvest and regrowth of forests by a factor of two in $198010.63 \times 10^{\text {is }} \mathrm{g}$ of 
TAale 7. Summary of results of tests $\alpha$ uncerainties in the estimates for harvest and regrowh of forests with the Terrestrial Caton Model. See text for devilis of each set of assumptions.

\begin{tabular}{|c|c|c|c|c|c|c|c|c|c|}
\hline \multirow[b]{3}{*}{ Assumpions } & & & \multicolumn{7}{|c|}{ Annual net release in 1980} \\
\hline & \multicolumn{2}{|c|}{ Total net release } & \multirow{2}{*}{ All } & \multirow{2}{*}{$\begin{array}{l}\text { Agrieul- } \\
\text { tural } \\
\text { clearing }\end{array}$} & \multirow{2}{*}{$\begin{array}{l}\text { Harvest } \\
\text { and } \\
\text { regrowith } \\
\text { of forests }\end{array}$} & \multirow{2}{*}{$\begin{array}{l}\text { Oxi- } \\
\text { dation } \\
\text { of wood } \\
\text { removed } \\
\text { from site }\end{array}$} & \multirow{2}{*}{$\begin{array}{l}\text { Abandon- } \\
\text { ment } \\
\text { of agricul- } \\
\text { ture }\end{array}$} & \multirow[b]{2}{*}{$\begin{array}{l}\text { Aftores } \\
\text { tation }\end{array}$} & \multirow{2}{*}{$\begin{array}{l}\text { Clearing } \\
\text { for } \\
\text { pasture }\end{array}$} \\
\hline & $\begin{array}{l}1860 \\
1980\end{array}$ & $\begin{array}{l}1958- \\
1980\end{array}$ & & & & & & & \\
\hline \multicolumn{10}{|c|}{ Net carton release (10,s) } \\
\hline $\begin{array}{l}\text { 3. The polutis andi-oased } \\
\text { analysis }\end{array}$ & 180 & 57.3 & 2.61 & 1.30 & 0.63 & 0.56 & -0.066 & -0.039 & 0.23 \\
\hline 9. Doubled harvest & 175 & 55.3 & 2.49 & 1.30 & 0.39 & 0.78 & -0.066 & -0.039 & 0.23 \\
\hline $\begin{array}{l}\text { 10. Increased live } \\
\text { residual }\end{array}$ & 162 & so.1 & 2.25 & 1.30 & 0.27 & 0.56 & -0.066 & -0.039 & 0.23 \\
\hline 11. Complete recovery & 164 & 51.6 & 2.27 & 1.30 & 0.36 & 0.56 & -0.084 & -0.083 & 0.23 \\
\hline $\begin{array}{l}\text { 12. 2. Increased rates } \\
\text { of regrowh } \\
\text { b. Reduced rates }\end{array}$ & $15 ?$. & 47.1 & 1.98 & 1.30 & 0.055 & 0.55 & -0.093 & -0.050 & 0.23 \\
\hline of regrowth & 214 & 66.6 & 3.15 & 1.30 & 1.12 & 0.55 & -0.046 & -0.0007 & 0.23 \\
\hline $\begin{array}{l}\text { 13. No loss of carbon } \\
\text { from soil }\end{array}$ & 163 & 51.4 & 2.30 & 1.30 & 0.34 & 0.56 & -0.073 & -0.050 & 0.23 \\
\hline $\begin{array}{l}\text { of carbon per } \\
\text { unit area }\end{array}$ & 152 & 4.7 & 1.98 & 1.03 & 0.43 & 0.49 & -0.066 & -0.039 & 0.14 \\
\hline $\begin{array}{l}\text { 15. Combination of } \\
\text { several tests }\end{array}$ & 100 & 32.1 & 1.38 & 0.81 & 0.086 & 0.49 & -0.059 & -0.083 & 0.14 \\
\hline
\end{tabular}

carbon in the population-based analysis and $0.36 \times$ $10^{13} \mathrm{~g}$ in this test: Table 7 . The net flux of carbon from all land-use changes was reduced from $2.61 \times 10^{\text {is }} \mathrm{g}$ to $2.27 \times 10^{12} \mathrm{~g}$ in 1980 . Over the 120 -yr period since 1860 the total net fiux from harvest and regrowth alone was $18 \times 10^{13} \mathrm{~g}$; it was $34 \times 10^{2 s} \mathrm{~g}$ in the population-based analysis.

Test 12: changing the rate of regrowth of forests. In the population-based analysis the regrowh time (to $75 \%$ of the carbon level of primary forests) was $50 \mathrm{yr}$ for all types of forests. We ran two extreme tests that modified this rate (Table 7). In one we permitted forests to regrow in a shorter time $(30 \mathrm{y}$ for temperate and boreal forests and 15 ye for tropical forests). In another test we assumed that all forests regrew in 100 yr following harvest. With a high rate of regrowth the annual net flux of carbon in 1980 was $=0.6 \times 10^{15} \mathrm{~g}$ less than in the population-based analysis because more of the harvested forests had already grown back. A slow rate of forest regrowth increased the release of carbon in 1980 by $\approx 0.5 \times 10^{13} \mathrm{~g}$.

In the long term when forests were permitted to regrow, the effect of harvests on the carbon of the atmosphere was small. In the short term. however, the rate of forest regrowth was important. If forests regrow after harvest faster than their products decay, the harvest of forests leads to a short-term storage of carbon. If the products are oxidized more rapidly than the forests regenerate, the short-term effect will be a release of carbon.

These results are of potential use in management of the atmospheric level of carbon dioxide. If a major increase in atmospheric carbon dioxide can be antic. ipated. one appropriate use of forests and forest products might be to ameliorate that increase. On the other hand. the growth of forests will store a limited quaintity of carbon in the short term at best. In the longer term of decades to centuries, it is the total mass of carton stored in both biomass and soils that is imporant.

Test 13: changing the response of soil carbon follouing harvest of a foresr. - Sudies of the effect of clear-autring in northem temperate forests indicate that - $50 \%$ of the carbon in the forest foor is lost is the $10-15$ yr following harvest. The forest floor is a layer of unincorporated organic matter $5-20 \mathrm{~cm}$ deep. It is not clear that the soil carbon to a depth of $1 \mathrm{~m}$ under. goes a similar reduction. There is recent evidence suggesting that the reduction in forest floor carton in forests of the southern United States is considerably $<50 \%$ following harvest (Gholz and Fisher 1982), and the same may be true for soils in tropical forests. In the model. the loss of carbon from soils following harvest in the population-based estimate was $50 \%$ for temper. ate. $15 \%$ for boreal. and $35 \%$ for tropical forests.

The importance of the uncertainties in the loss of soil carbon was examined in this test with the assumption that the organic matter in soils is unchanged following harvest. Plant debris left in the forest at the time of harrest decayed over time, as in the population-based estimate.

The results show that while this alternative assump. tion made a difference of only $11 \%$ in the total nes flux 
TAgle 8. Estimales of annual net carbon fux between terrestrial ecosystems and the atmosphere in or aboul 1980. Positive values indicate net release to the atmosphere.

\begin{tabular}{lc}
\hline \multicolumn{1}{c}{ Reference } & $\begin{array}{c}\text { Carbon flux } \\
\left(10^{4 s} g / y r\right)\end{array}$ \\
\hline Woodwell and Houghton 1977 & $2.5-20$ \\
Adams et al. 1977 & $0.4-1.6$ \\
Bolin 1977 & $0.4-1.6$ \\
Wong 1978 & 1.9 \\
Woodwell et al. 1978 & $4-8$ \\
Hampicke 1979 & $1.5-4.5$ \\
Seiler and Crutzen 1980 & $-2.0-2.0$ \\
Moore et al. 1981 & $2.2-4.7$ \\
This study & $1.8-4.7$ \\
\hline
\end{tabular}

for 1980. it reduced the net fux from harvested and regrowing forests by almost $50 \%$ (Table 7 ).

Test 14: changing the amount of carbon per unit area in the regetation and soils of different ecosysrems. - For the population-based estimate, we used the Whittaker and Likens (1973) review of carbon in the biota to assign carbon values to ecosystem types. Other students of world vegetation have argued that these values refer to exceptionally productive or undisturbed sites and that the mean biomass for a particular forest type is less (Olson et al. 1978. Ajtay et al. 1979. Brown and Lugo 1980). In this test (Appendix 7) we replaced the mean biomass (Whittaker and Likens 1973) and soil carbon (Schlesinger 1977 ) values for tropical forests with those suggested by Brown and Lugo (1980). We combined the six forest types given by Brown and Lugo into two types and calculated means weighted by area. These new values ranged from 34 to $78 \%$ of the tropical forest biomass or soil carbon values used in the population-based estimate. We assumed that these values referted to the primary or undisturbed tropical forests and that secondary forests reach $75 \%$ of the carbon in primary forests.

The results showed a total release of carbon over the 120 yr since 1860 of $152 \times 10^{* 3} 8$ and a release of $1.98 \times 10^{15} \mathrm{~g}$ in 1980 (Table 7). Clearty, if the carbon content of a forest is low, less carbon will be released during its harvest or its conversion to agriculture. On the other hand. less carbon will be taken up during forest regrowth, so the total net release does not proportionately reflect the very drastic changes in forest biomass.

Test 15: combining several rests in an effort to luwer the estimated net release of carbon from the biota and soils. - In the tests discussed above. we have examined one factor at $a$ time in an effort to determine how uncertainty in data and assumptions affects the results of an analysis of the biotic release of carbon. In this test we included simultaneousty several factors that individually reduced the net flux of carbon to the atmosphere. The purpose was to see if we could make the biota and soils a net accumulator of earbon in
Table 9. Estimates of the net release of arbon from terrestrial biota and soils to the atmosphere during the last century based on models using carbon isolope racios in tree rings.

\begin{tabular}{|c|c|c|}
\hline Reference & $\begin{array}{c}\text { Time } \\
\text { interval }\end{array}$ & $\begin{array}{c}\text { Release of earbon from } \\
\text { terrestrial biou and soils to } \\
\text { atmosphere during interval } \\
\left(10^{4 s} \mathrm{~g}\right)\end{array}$ \\
\hline $\begin{array}{l}\text { Stuiver } 1978 \\
\text { Wagener } 1978 \\
\text { Freyer } 1978 \\
\text { Siegenthaler }\end{array}$ & $\begin{array}{l}1850-1950 \\
1800-1935 \\
186 a-1974\end{array}$ & $\begin{array}{r}120 \\
170 \\
70\end{array}$ \\
\hline $\begin{array}{l}\text { et al. } 1978 \\
\text { Tans } 1978 \\
\text { This study }\end{array}$ & $\begin{array}{l}1860-1974 \\
1850-1950 \\
1860-1980\end{array}$ & $\begin{array}{c}157-195 \\
150 \\
135-228\end{array}$ \\
\hline
\end{tabular}

1980: however. the assumptions were not considered realistic.

The factors we changed included: (1) 100\% rather than $75 \%$ recovery of vegetation and soil following disturbance (Test 11 ). (2) a 34-78\% lower amount of carbon per unit area in vegetation and soil (Test 14). (3) no loss of soil carbon following harvest of forests (Test 13). and (4) a 20\% rather than 50\% loss of soil carbon with conversion to agriculture (Test 81 .

The resuits of this combination of assumptions and data showed a net flux of carton of $1.38 \times 10^{13} \mathrm{~g}$ to the atmosphere in 1980 and a total net release over the past 120 yr of $100 \times 10^{15} \mathrm{~g}$. As expected, these fiuxes are smaller than those resulting from any other test (Tables 4,6 . and 7 ). The three factors affecting the flux of arbon from harvest of forests combined to make the net tux from harvests approach zero in 1980 $\left(0.086 \times 10^{\text {ws }} \mathrm{g}\right)$. The clearing of band for agriculture and the decay of wood accounted for almost the entire net release (Table 7 ).

The results of this test show that when the assumptions and data of individual tests are combined, they may interaet such that the reults of the combination are not easily predictable from the results of the individual tests. An analysis of Tests 8. 11. 13. and 14 sugsests that without interaction the net release of carbon in 1980 would have been $1.07 \times 10^{13} 8$ instead of the $1.38 \times 10^{13} \mathrm{~g}$ actually calculated. Thus. in spite of the fact that many tests produced releases in 1980 that were less than those in the population-based estimate. a test including all of those tests simultaneously would not necessarily lower the estimated net release of carbon in 1980 below $1 \times 10^{15} \mathrm{~g}$.

\section{Discussion}

Three approaches have been used to determine how the tertestrial biota and soils affect the $\mathrm{CO}_{2}$ content of the atmosphere. These include direet estimates (used in this paper) based on data showing changes in the area of ecosystems with different amounts of carbon per unit area. indirect estimates based on changes in the ratios of carbon isotopes in tree rings and corals. 
and other indirect estimates based on the difference between the amount of carbon released from fossil fuels and the amount accounted for in the atmosphere (measured) and transferred to the oceans (calculated) (Eq. 1). The three approaches do not measure the same quantity and may not yield similar fluxes of carbon. The direct approach based on changes in area ignores changes in the amount of carbon per unit area that may occur within undisturbed areas. Such changes could be either positive or negative. The two indirect approaches ideally yield a flux that includes both aspects of the terrestrial carbon flux (changes in area of ecosystems and changes in the carbon content of undisturbed ecosystems), but the two aspects cannot be distinguished.

On the basis of the direct analyses presented here the estimate of the net release of carbon from vegetation and soils in 1980 ranges between 1.8 and $4.7 \times$ $10^{15} 8$ (Table 4). Other direct estimates of the global biotic fux of carbon based on statistics of worldwide forestry and agriculture have also generally indicated that tertestrial ecosystems as a whole release carbon (Table 8), although specific regions may show a net accumulation of carbon (Armentano and Ralston 1980. Delcourt and Harris 1980. and Fig. 7). Over the 120-yr period 1860-1980. the range of the net flux of carbon calculated here was $135-228 \times 10^{15} \mathrm{~g}$. Isotopic evidence from tree rings suggests a release of carbon of between 70 and $195 \times 10^{15} 8$ over the past century or more (Table 9). Global models based on oceanographic and atmospheric data, in constrast. suggest that the bioca must be eicher in an equilibrium or accumulating on the order of $1 \times 10^{13} \mathrm{~g}$ of carbon currently (see below).

The approach presented here is more complete than other direct analyses in that it includes the response of soil organic matter and the decay of wood products in the calculated fux of carboa. If oaly the vegetation had been included in our analyses, the net fux of car. bon in 1980 would have been half as large as in the population-based estimate (Table 5 ). The flux would have included only the rapid oxidation of wood bumed $\left(0.89 \times 10^{15} \mathrm{~g}\right.$ of $\left.\mathrm{C}\right)$. the slower decay of plant material left to decay on harvested or cleared sites $\left(2.26 \times 10^{2 s}\right.$ $g$ of $C)$. and the regrowth of forests on harvested. abandoned, or afforested areas $\left(-1.97 \times 10^{\text {ss }} \mathrm{g}\right.$ of $\mathrm{C}$. for a net flux of only $1.18 \times 10^{\text {1s }} \mathrm{g}$ of carbon for the world in 1980. Including soils in the analysis added another $0.87 \times 10^{15} \mathrm{~g}$ of $\mathrm{C}$ to the net flux (similar to the Schlesinger [1983] estimate). and including the decay of wood removed from forests contributed another $0.56 \times 10^{13} \mathrm{~g}$. Thus, soils and wood products together contribute as much to the flux of carbon as does vegetation.

Oceanographic and atmospheric modellers (Bacastow and Keeling 1973. Machta 1973, Oeschger er al. 1975. Siegenthater and Oeschger 1978. Broecker et al. 1979) have approached the role of the biota $(L)$ by

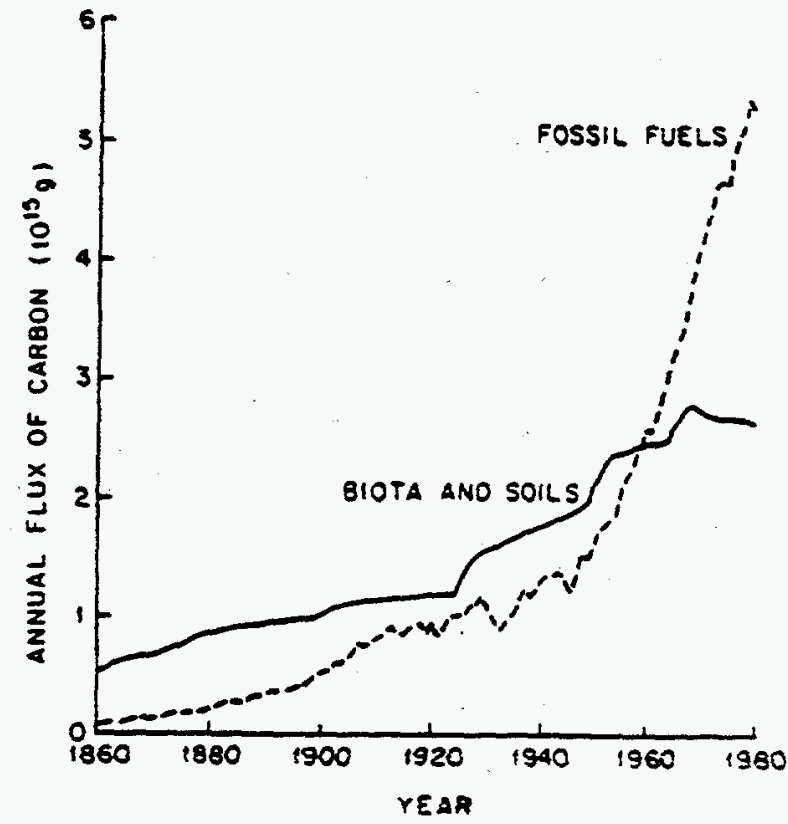

FiG. 8. Nel liux of carbon to the atmosphere as a resuit of land-use changes and harvests (the population-based estimate: $\rightarrow$ and as a result of the combustion of fossil fuel (- - - : Rotty 1981a. b).

calculating the difference between the amount of carbon released annually from the combustion of fossil fuels $(F)$ and the amount that accumulates in the atmosphere $(A)$ and in the modelled oceans $(S)$ :

$$
\begin{gathered}
L=F \quad-F(2) \\
0.7( \pm 1.4)=5.2( \pm 0.7)-2.5( \pm 0.2)-2.0(-0.5)
\end{gathered}
$$

The values in Eq. 2 correspond to the amual fluxes of carbon (in $10^{13} \mathrm{~g}$ ) in 1980 . The 20 mas increase in atmospheric $\mathrm{CO}_{2}$ was estimated from measurements made at Muma Loa (Bacastow and Keeling 1981. R. Bacasrow and C. D. Kedina persomal commenication). The release of carbon from contustion of fossil fueis in 1980 is Rotty's $(19816)$ estimate. The splake by the oceans was assumed to be $39 \%$ of the amount released from fossil fuels (Broecker et al. 1979). The numbers in parentheses represent rough estimates of the errors of each of the terms in the equation: 12$15 \%$ for the fossil fuel term (Keeling 19736), 20-25\% for oceanic uptnke (Broecker et al. 1979). and $=10 \%$ or less for the atmospheric measurements IBacastow and Keeling 1981 ).

To reduce the effect of short-term varizions in the rate of increase in atmospheric $\mathrm{CO}_{2}$, the equation can be evaluated for the 22-yr period of the Mauna Loa record (1958-1980) (Fig. 9):

$$
\begin{aligned}
& L=F-A-S(3) \\
& 2.2( \pm 19.2)=85.5( \pm 11.5)-49.9( \pm 0.2)-33.4(=7.5)
\end{aligned}
$$

The conclusions are essentially the same. When the role of tertestrial ecosystems is calculated by difference using the equation. the biota and soils are ap- 


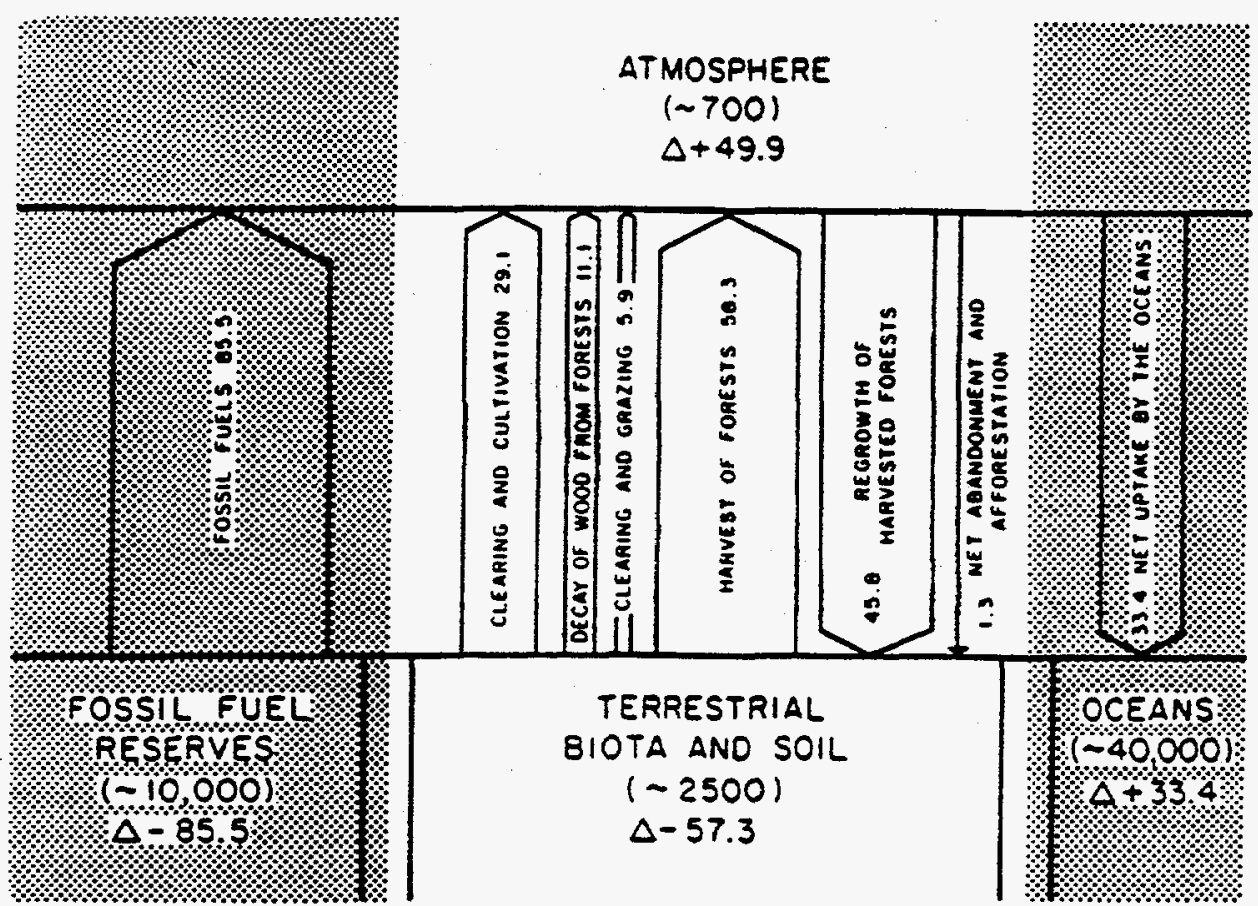

FiG. 9. Ner flux of carbon (in 10's grams) between terrestrial ecosystems and the atmosphere from 1958 to 1980 as a result of changes in the use of land. and the net flux of earbon between the other major components of the global carton cycie during the same interval of time. According to the most recent analyses. the carbon cycle is not balanced: the releases are greater than the storages.

parently accumulating carbon, albeit at a rate not significantly different from zero. In contrast, the biota and soils appear to be releasing carbon when the net changes in the carbon of biota and soils are calculated directly on the basis of land-use practices during the past century. According to the analysis presented here. the net release of carbon from terrestrial systems since 1860 has equalled or exceeded the release from fossil fuels $\left(180\right.$ vs. $\left.160 \times 10^{15} \mathrm{~g}\right)$. Only in the last two decades has the release of $\mathrm{CO}_{2}$ from use of fossil fueis (Rotty 198 la. b) exceeded the rate of carbon release caused by changes in the use of land worldwide (Fig. 8). Over the period since 1958 our estimate of net release of carbon from terrestrial systems was $57.3 \times$ $10^{13} \mathrm{~g}$ according to the population-based analysis (Fig. 9).

The range of the net release identified in this study is narrower than earlier estimates (Woodwell and Houghton 1977, Woodwell ef al. 1978), but some of the values are still too high to balance the global carbon budget ( Eq. 2). If the actual net fux of carbon from the biota and soils is at the low end of the range. it is within the combined ertor of the other terms in the equation. and the carbon budget may balance. If the actual flux is near the high end of the range. however. the budget is seriously out of balance, and our current understanding of the global carbon cycle is incomplete.

One possibility we have not considered here is that the carbon content of undisturbed ecosystems has changed. Such changes, often referred to as the biotic growth factor. might occur as a result of increased concentration of atmospheric $\mathrm{CO}_{2}$ (Lemon 1977 . B. R. Strain. personal communication). increased levels of available nutrients. or changes in temperature and moisture. We have little ecological or physiological basis for expecting (Kramer 1981), and no evidence to support, an increase in biomass or soil carbon glob. ally. On the contrary, an increase in the average temperature of the earth. as occurred during this century (Mitchell 1961. Salinger 1979). might be expected to increase ecosystem respiration relative to photosynthesis and hence release carbon to the atmosphere.

We believe several other mechanisms of carbon storage frequently invoked to balance the global carbon budget to be irtelevant in the context of the global carbon question. For example, the increased productivity of agricultural crops in recent times is irrelevant because the production is consumed (oxidized) within a year: it does not appear as an increased storage of carbon. Similariy, if fluxes of carbon are in a steady state in areas away from human influence. then. the flux of carbon in net primary productivity can be ignored, even if it has been underestimated (Smith 1981 ). The assumption of steady state permitted us to consider only those areas that have been disturbed: the area and carbon content of undisturbed ecosystems need not be known at all and need not be considered in the analysis. In the same way. the burial of carbon as elemental carbon or charcoal as a result of fires 
(Seiler and Crutzen 1980) is not important, except as the rate of burning and formation of charcoal is changing currently. Similarly the export of terrestrial carbon to the sea by rivers (Lugo and Brown 1980. Richey et al. 1980) is not important in this context. no matter how large, unless it has changed drastically in recent times. Each of these fluxes has been invoked recently to account for a net storage of carbon and to balance the equation of the global carbon cycle. We have no evidence, however, that such fluxes have changed sufficiently since preindustrial times to be important in the $\mathrm{CO}_{2}$ question. and we have not included steadystate fluxes in this anaiysis.

The discrepancy between the tertestrial analyses and those of the ocean modellers is unresolved. The important questions are: what is the net flux of carbon from the tertestrial biota and soils to the atmosphere. and is it near the high or low end of the range presented here? It is therefore essential that we improve. the precision of the estimate of fux. The most efficient way to improve the precision is to use the model to indicate where further information is required to help nartow the range of estimates. The model indicates that the largest source of carbon released into the atmosphere is from forested lands transformed inzo agriculture. This transfer at present is most important in the tropies (Fig. 7. Appendices 2. 3, and 4), yet one of the largest areas of uncerainty is the rate of transformation of tropical forests. Current estimates of this rate vary considerably. Tests of factors other than the rates of clearing or the types of ecosystems cleared gave a range of only 1.98-3.15 $\times 10^{13} \mathrm{~g}$ of carbon. almost $60 \%$ less than the overall range. No other single factor we tested produced a range greater than that produced by the uncertainty in rates of clearing. Monitoring tropical regions with LANDSAT may be an effective method for measuring these rates of change since 1972, the time interval most important for contemporary analyses. The larzest changes in the storage of carbon. those associated with the transformation of forest to nonforest, are the changes most easily detectable with LANDSAT, and coverage is wortdwide.

The analyses given here did not include several landuse changes that have the potential for changing the amount of carbon released from terrestrial systems. Some of these changes that would reduce the estimated release of carbon include the suppression of forest fires (Pyne 1982), the expansion of paddy rice agriculture (Institute of Soil Science. Academia Sinica 1978), and the expansion of no-tillage agricuiture (Phillips et al. 1980). Other changes that would increase the net release of carbon inciude the drainage of wetlands for agriculture (Armentano 1980), the increasing intensity of shifuing cultivation (Scott 1977. UNESCO 1978). the reduction in carbon per unit area from grazing and overgrazing (Parsons 1976. Sanchez and Tergas 1979). and the increasing area of arid lands (Eckholm and Brown 1977, Council on Environmental Quality 1980).
However. Schlesinger (1982) suggests that carbonates may increase in arid lands. Including all of these changes in the analyses would probably increase the net release of carbon from the biota and soils. but. although such factors may be large locally. their importance world wide is likely to be similar to the rather minor effects of afforestation or agricuitural abandonment analyzed here.

Improvement of the estimate of the net flux of carbon from terrestrial systems requires more than the incorporation of additional land-use changes in the analysis, however. The regions and ecosystems in the model are large and heterogeneous units, while the data used to describe the response curves. for example, were obtained from studies in specific areas. Each of the parameters given in the tables and appendices was chosen on the basis of available data and judgment: each is subject to argument and change. Yet. it is important to note that despite large changes in these parameters introduced in our tests. the calculated thux of carbon for 1980 did not clange $>0.6 \times 30^{13} \mathrm{~g}$. A reasonable next step is 10 conduct decaited studies of imporant regions. If the necessary data are available. such studies will improve the precision of the estimated flux. Our best estimate of the net carbon flux at the moment. however, is: a total release of carbon since 1860 of $135-228 \times 10^{13} 8$ and an annual release in 1980 of $1.8-4.7 \times 10^{25} \mathrm{~g}$.

\section{ACKNOWLEDOMENTS}

The authors acknowledge with pleasure the contributions of Ms. Cheryl Palm and Mr. Richard Boone in the search for and improvement of date used in these analyses and the contribution of Mr. David Skole in maintaining the utility of the model throughout is mucrerous modifications.

The researet ws suppored by National Science Foundation Grax DEB-79-2329 and by the Ecosystems Center.

\section{Literature Citeo}

Adams. J. A. S.. M. S. M. Mantovari. and L. L. Lundell. 1977. Wood versus fossil fuel as a source of excess carbon dioxide in the atmosphere: a preliminary report. Science 19:54-56.

Ajuy, G. L.. P. Ketner. and P. Duvigneaud. 1979. Tertestrial primary production and phytomass. Pages 129-182 in B. Bolin. E. T. Degens. S. Kempe. and P. Ketner. editors. The global carton cyete. SCOPE 13. J. Wiley and Sons. New York. New York. USA.

Armentano. T. V. 1980 . Drainage of organic soils as a factor in the world carbon cycle. BiaScience 30:825-830.

Ammentano. T. V.. and C. W. Ralston. 1980 . The roie of temperate zone forests in the global carbon cycie. Canadian Joumal of Forest Research 10:53-60.

Arnold. J. E. M.. and J. Jongme. 1978. Fuelwood and char. cosil in devefoping countries. Urasylva 29:2-9.

Aweto. A. O. 1981 . Organic matter build-up in fallow soil in a part of southwestern Nigeria and its effects on soil properties. Joumal of Biogeography 8:67-74.

Bacastow, R.. and C. D. Keeling- 1973. Atmospheric carbon dioxide and radiocarbon in the natural carbon cycle: II. Changes from A.D. 1700 to 2070 as deduced from a geochemical model. Pages $86-135$ in G. M. Woodwell and E. V. Pecan. editors. Carbon and the biosphere. Unied States Atomic Energy Commission Symposium Series 30. 
National Technical Information Service. Springtield, Vifginia. USA.

Bacastow, R., and C. D. Keeling. 1981. Atmospheric carbon dioxide concentration and the observed airbome fraction. Pages 103-112 in B. Bolin, editor. Carbon cycie modelling. SCOPE 16. J. Wiley and Sons. New York. New York. USA.

Bart. T. N. 1982. The world food situation and global grain prospects. Science 214: 1087-1095.

Billings, W. D.. J. O. Luken. D. A. Mortensen, and K. M. Peterson. 1982. Aretic tundra: a source or sink for atmospheric carbon dioxide in a changing environment. Decologia (Bertin) 53:7-11.

Bolin. B. 1977. Changes of land biota and their importance for the carbon cycie. Science 196:613-61s.

Brewer. P. G. 1978 . Direct observation of the oceanic $\mathrm{CO}_{2}$ increase. Geophysical Research Letters 5:997-1000.

Broecker. W. S.. T. Takahashi. H. J. Simpson. and T.-H. Peng. 1979. Fate of fossil tuel eabon dioxide and the global carbon budget. Science 206:409-118.

Brown. L. R. 1981. World poputation grown, soil erosion. and food security. Science 214:99S-1002.

Brown. S., and A. E. Lugo. 1980 . Preliminary estimate of the storage of organic carbon in tropical forest ecosystems. Pages 65-117 in A. E. Lugo. S. Brown. and B. Liegel. editors. The role of tropical forests on the worid carbon eycle. United States Department of Enerzy. Office of Environment, Washington. D.C.. USA.

Buringh. P. 1983, in press. Organic carbon in soils of the world. In G. M. Woodwell. editor. The role of terrestrial vegecation in the global earbon cycte: measurement by re. mote sensing. SCOPE. J. Wiley and Sons. New York. New York. USA.

Chen. C.-T.. and F. J. Millero. 1979. Gradual increase in oceanic $\mathrm{CO}$. Nawre 277:205-206.

Clarke, W. C. 1976. Maintenance of agriculture and human habicats within the tropical forest ecosystem. Human Ecology 4:247-259.

Clawson. M. 1979. Forests in the long sweep of American history. Science 204:1168-1174.

Council on Environmental Quality. 1990. The global 2000 report to the President. United States Government Printing Office. Washington. D.C.. USA.

- 1981. Global enerey futures and the carbon dioxide problem. Superintendeat of Documeats. Uaired States Government Printing Office, Washington. D.C.. USA.

Covington. W. W. 1977 . Forest foor orparic maner and nutrient conteat of leaf fall curing secondary succession in northern hardwoods. Dissertation. Yale University. New Haven, Connecticut, USA.

Cunningham, R. K. 1963. The effect of clearing a tropical forest soil. Jourmal of Soil Science 14:334-345.

Delcour. H. R., and W. F. Harris. 1980. Carbon budget of the southeastern U.S. bioca: analysis of historical change in trend from source to sink. Science 210:321-322.

Eckholm. E., and L. R. Brown. 1977. Spreading desertsthe hand of man. Woridwatch Paper 13. Worddwatch Instinute, Washington, D.C., USA.

FAO. 1946. Forestry and forest products: wortd siruation 1937-1946. Stockholms Bokindustri Aktiebolag, Stockholm. Sweden.

- 1946-1979. Yearbook of forest products. FAO. Rome, Italy.

Rom. 1948. Forest resourees of the world. Unasylva 2: $160-182$.

1949-1978. Production yearbooks. FAO. Rome. Italy.

1955. World forest resources-1953. FAO. Rome. Italy.
Iealy.

1960. World forest inventory-1958. FAO. Rome.

Inaly.

Italy.

1966. World forest inventory-1963. FAO. Rome.

1976. European timber trends and prospects 1950 2000. FAO. Rome. Italy.

Fleuret. P., and A. Fleuret. 1978. Fuelwood use in a peas. ant community: Tanzanian case study. The Joural of Developing Areas 12(3):31S-322.

Freyer, H. D. 1978. Preliminary evaluation of past $\mathrm{CO}_{2}$ increase as derived from ${ }^{12} \mathrm{C}$ measurements in tree rings. In J. Williams. editor. Carbon dioxide, climate. and society. Pergimon Press. New York. New York. USA.

1979. On the "ac record in tree rings. Pan 1. " $\mathrm{C}$ variations in northern hemispheric trees during the last 150 years. Tellus $31: 124-137$.

Gholz. H. L.. and R. F. Fisher. 1982. Organic matter production and distribution in slash pine (Pinus elliotii) plantacions. Ecolony 63:1827-1839.

Giddens. J. 1957. Rate of loss of earbon from Georin soils. Proceedings of the Sail Science Society of Amerie 21:513sis.

Grigs. D. B. 1974. The agricultural systems of the world: an evolutionary approach. Cambridge University Press. Cambridge, England.

Haas, G. J.. C. F. Evans, and E. F. Miles. 1957. Nitrogen and earbon changes in Greas Plains soils as infuenced by cropping and soil treatments. United States Departmeat of A griaulture Technical Bulletin 1164.

Hampicke. U. 1979. Man's impact on the earth's vegezation cover and its effects oa carbon cycle and elimate. Pages 139-159 in W. Back. J. Pankath, and G. Russell. editors. Man's impact on climate. Elsevier Scientific. New York. New York. USA.

Har. G. 1961. Humus depths under cut and uneut northem hardwood forests. Northeastern Forest Experiment Station. Forest Research Note 113 . United States Forest Service. Washington. D.C.. USA.

Har. J. F. 1968. Loss and abandonment of cleared farm land in the eastern United States. Annals of the Association of American Geographers 5:417-440.

Hough. F. B. 1878. Report upon forestry, prepared under the direction of the Commissioner of Agriculture. in pursuance of an Act of Congress. approved August is. 1876. Volume 1. United States Government Priating Otfice. Wastineroa. D.C.. USA.

1880. Report upon forestry, prepared under the direction of the Commissioner of Agriculture, in pursuance of an Act of Congress, approved August 15, 1876. Volume 2. United States Government Printins Oftice, Washington. D.C.. USA.

1882. Repart upon forestry, prepared under the direction of the Commissioner of Agriculture. in pursuance of an Act of Congress. approved August 15. 1876. Volume 3. United States Government Printing Office. Washington. D.C.. USA.

Ilvessalo. L.. and M. Jalava. 1930. Forest resources of the world. Communicationes Ex Instituto Queaestionum Forestalium Finiandiae Edizae 16, Helsinki. Fintand.

Instiute of Soil Science. Academia Sinica. 1978. Soils of China. Science Press. Beijing, China.

Intemational Institute of Agriculture. 1922. International yearbook of agriculural statisties 1909-1921. IIA. Rome. Italy.

1939. The first world agricultural census (1930). Volumes I-V. IIA. Rome. Italy.

John. D. M. 1973. Accumulation and decay of litter and net production of forest in tropical West Africa. Oikos 24: $430-435$. 
Keeling. C. D. 1973e. The arbon dioxide cycle: reservoir models to depict the exchange of atmospheric carbon dioxide with the oceans and land plants. Pages 251-329 in S. 1. Rasool, editor. Chemistry of the lower atmosphere. Plenum Press, New York. New York. USA.

19736. Industrial production of carbon dioxide from fossil tuels and limestone. Teflus 25:174-198.

Keeling, C. D., J. A. Adams, Jr.. C. A. Ekdahi, Jr., and P. R. Guenther. 1976a. Atmospheric carbon dioxide variations at the Souch Pole. Tellus 28:S52-564.

Keetins, C. D.. and R. B. Bacastow. 1977. Impact of industrial gasses on climate. Pages 72-95 in Energy and climate. National Academy of Sciences. Wastington. D.C. USA.

Keeling, C. D.. R. B. Bacastow, A. E. Bainbridge, C. A. Ekdahl. Jr.. P. R. Guenther. and L. S. Waterman. 1976 b. Atmospheric carbon dioxide variations at Mauna Loa Observatory, Hawaii. Tellus 28:538-551.

Kramer, P. J. 1981. Carton dioxide concentration, photo synthesis and dry matter production. BiaScience 31:29-33.

Krebs. J. E. 1975. A comparison of soils under apriculture and forests in San Carlos. Cosen Rica. Pages 381-390 in F. B. Golley and E. Medina. editors. Tropical ecolorical sys. terms. Volume II. Ecological studies. Springer-Vertas. New York. New York. USA.

Küchier, A. W. 1964. World natural vegetation map. In E. B. Epenshade, Jr.. editor. Goode's world atlas. RandMcNally. Chicago, Illinois. USA.

Lanly, J. P., and M. Gillis. 1980. Provisional results of the FAOUNEP tropical forest resources assessment project: tropical America. FAO, Rome, Italy.

Lemon. E. 1977. The land's response to more carbon dioxide. Pages 97-130 in N. R. Andersen and A. Malahoff. editors. The fate of fossil fuel $\mathrm{CO}_{2}$ in oceans. Plemum Press. New York. New York. USA.

Lugo. A. E., and S. Brown. 1980. Tropical forest ecosys. tems: sources or sinks of atmospheric carbon. Unasylva 32:8-13.

Lutz. H. J., and R. F. Chandler. 1946. Forest soils, J. Wiley and Sons. New Yort. New York. USA.

MacDonald. G. J. F. 1978. An overview of the impact of carton dioxide on climate. M78-79. MITRE Corporation. MeLean. Virginia. USA.

Machia. L. 1973. Prediction of $\mathrm{CO}$ in the atmosphere. Pases 21-31 in G. M. Woodwell and E. V. Pecan, editors. Carbon and the biospbere. United States Atomie Eneroy Commission Symposium Series 30. Nations Technical Information Service, Springfield. Virpinia, USA.

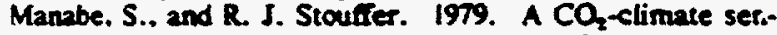
sitivity study with a mathermetical model of the stobal ctimate. Namure 22:491-493.

Manabe. S.. and R. T. Wetherald. 1980. On the distribution of climate change resulting from an increase in $\mathrm{CO}_{2}$-content of the atmosphere. Jourmal of Atmospheric Science 37:99 118.

Marks, P. L., and F. H. Bormann. 1972. Revegetation folfowing forest cutting. Mechanisms for renum to steadystate nutrieat cycling. Science 176:914-915.

McEvedy. C., and R. Jones. 1978. Attas of world population history. Penpuin Books. Middlesex. Engiand.

Mitchell. B. R. 1975. European historical statistics 1750 1970. MacMGillan. London. England.

Mitchell. J. M. 1961. Recent secular changes of global temperanure. Anmais of the New York Academy of Sciences 95:235-250.

Moller. C. 1947. The effect of thinring. age, and site on foliage increment and loss of dry matter. Joumal of Forestry 45: 393-404.

Moore. B.. R. D. Boone. J. E. Hobbie. R. A. Houghton. J.
M. Metillo. B. J. Peterson. G. R. Shaver, C. J. Vorosmarty, and G. M. Woodwell. 1981. A simple model for andysis of the role of tertestrial ecosystems in the global car. bon budget. Pages 365-385 in B. Bolin. editor. Modelling the global carton cycie. SCOPE 16. J. Wiley and Sons. New York. New Yort. USA.

Morey, H. G. 1942. The application of our knowledge of the organic layers of the soil profile to flood control. In F. T. Mavis. editor. Proceedings of the hydrology conference held at State Colleze. Penssylvania. June 30-July 2. 1941. School of Engineering. Technical Bulletin 27. Pennsylvania State University. Seate College. Pennsylvania, USA.

Myers. N. 1980a. Report of survey of conversion rates in tropical moist forests. National Research Council. Washingeon. D.C.. USA.

- 19806. The present and future prospects of tropical moist forests. Environmental Conservacion 7:101-114.

Nye. P. H.. and D. J. Greeniand. 1960. The soil under shiftine euttivation. Technical Communication SI. Commonwealth Bureau of Soils. Harpenden. Engtand.

Nye. P. H.. and D. J. Greenland. 1964. Changes in the soil after cleariag tropical forest. Plant and Soil 21:101-112.

Oeschger. H.. U. Siegenthaler. U. Schotterer. and A. Guglemann. 1975. A box diffusion model to study the carton dioxide exchange in nature. Tellus $57: 168-192$.

Olson. J. S. H. A. Pruderer. and Y. H. Chan. 1978. Changes in the global carbon cycle and the biosphere. ORNLEIS109. Oak Ridge National Laboratory. Oak Ridge. Tennessee. USA.

Openshaw. K. 1974. Wood fuels the developing world. New Scientist 61:271-272.

1978. Woodfuet a time for re-assessment. National Resources Forum 3:35-51.

Ovingon. J. D. 1968. Some factors affecting nutrient distribution within ecosystems. Pages 95-105 in F. E. Eckardi. editor. Functioning of terrestrial ecosystems of the primary production level. UNESCO. Liege. Belgium.

Pales, J. C., and C. D. Keelins. 1965. The concentracion of atmospheric carbon dioxide in Hawaii. Joumal of GeoPhysied Research 70:6053-6076.

Parsons. J. J. 1976. Forest to pasture: development or destruction? Revista de Biologia Tropical 2A1): $121-138$.

Persson. R. 1974. World forest resources: review of the world's forest resources in the earity 1970's. Research Note 17. Royal College of Forestry. Stockholm. Sweden.

Phillips. R. E.. R. L. Blevins, G. W. Thomas. W. W. Frye. and S. H. Phillips. 1980. No-tillage agriculure. Science 203: $1108-1113$

Popenoe. H. 1957. The influence of the shifting cultivation cycle on soil properties in Central America. Proceedings of the Pecitic Soience Congress 5.72-T.

Puhr. L F.. and W. W. Worzella. 1952. Fertility mainte. nance and management of South Dakota soils. Circular 9?. South Dakota Agricuitural Experiment Station. Brookings. South Dakota. USA.

Pyne. S. J. 1982. The cultural history of wildland and rural fre. Princeton University Press. Princeton. New Jersey. USA.

Reed. W. E. 1951. Reconnaissance soil survey of Liberia. Agricultural Information Bulletin 66. United States De. partment of Agriculture, Washington. D.C.. USA.

Revelie. R., and W. Munk. 1977. The carbon dioxide eycle and the biosphere. Pages 243-280 in Energy and climate. National Academy of Sciences. Washington. D.C.. USA.

Reynolds, R. V., and A. H. Pierson. 1942. Fuelwood used in the United States 1630 - 1930. Circular 641 . United States Department of Agricuiture. Washington. D.C.. USA.

Richards. J. F. 1982 . History of global land clearing 1860 
1980. Instizute for Energy Analysis. Oak Ridge Associated Universities. Oak Ridige. Tennessee. USA.

Richey, J. E.. J. T. Brock, R. J. Naiman. R. C. Wissmar. and R. F. Stallard. 1980 . Oreanic carton: oxidation and transport in the Amazon River. Science 207:1348-1351.

Robertson. C. J. 1956. The expansion of the arable area. The Scottish Geographical Magazine 72(1):1-20.

Rotty. R. M. 1981 la. Data for elobal $\mathrm{CO}_{2}$ production from fossil fuels and cement. Pages $121-125$ in B. Bolin. editor. Carbon cycle modelling. SCOPE 16. J. Wiley and Sons. New York. New York, USA.

19816 . Distribution and changes in industrial carbon dioxide production. Institute for Energy Analysis. Oak Ridge Associated Universities, Oak Ridge. Tennessee. USA.

Salinger, M. J. 1979. New Zealand climate: the temperature record, historical data and some agricultural implications. Climatic Change 2: 109-126.

Salter. R. M.. R. D. Lewis. and J. A. Slipher. 1941. Our heritage-the soil. Extension Bulletin IFS. Ohio Agricultural Experiment Station. Athens. Ohio, USA.

Sanchez. P. A.. and L. E. Tergas, editors. 1979. Pasture production in acid soils of the Tropics. Centro Internacional de Agricultura Tropical. Cali. Colombia.

Sarzz. R. S.. and W. D. Huttinger. 1950. Some factors affecting humus development in the northeast. Joumal of Foresiry 48:341-344.

Schlesinger. W. H. 1977. Carbon balance in terrestrial detritus. Annual Review of Ecology and Systematics 8:5181.

11. 1982. Carbon storage in the caliche of arid soils: a case study from Arizona. Soil Science 133:247-255.

1983. in press. The wortd carbon pool in soil organic matter: a source of atmospheric $\mathrm{CO}_{2}$. In $\mathrm{G}$. $\mathrm{M}$. Woodwell. editor. The role of terrestrial vegetation in the global carbon cycle: measurement by remote sensing. SCOPE. J. Wiley and Sons. New York. New York. USA.

Scott. G. 1977. The importance of old-field succession biomass increments to shifting cultivation. Great Plains-Rocky Mountain Geographical Journal 6:318-327.

Seiler. W.. and P. J. Crutzen. 1980 . Estimates of gross and net fluxes of carbon between the biosphere and the atmosphere from biomass burning. Climatic Change 2:207-247.

Siegenthaler. U.. M. Heimann. and H. Oeschger. 1978. Model responses to the atmospheric $\mathrm{CO}_{2}$ level and ${ }^{12} \mathrm{C}_{1 / 2} \mathrm{C}$ ratio to biogenic $\mathrm{CO}_{2}$ input. Pages $79-87$ in $\mathrm{f}$. Williams. editor. Carbon dioxide. climate and society. Pergamon. New York. New York. USA.

Siegenthaler. U.. and H. Oeschger. 1978. Predictigs fuwre atmospheric carbon dioxide levets. Science 199:388-394.

Smith. S. V. 1981 . Marine macrophytes as a global carbon sink. Science 211:838-840.

Stuiver. M. 1978. Atmospheric carbon dioxide and carbon reservoir changes. Science 19\%:253-270.

Swift. M. J.. O. W. Heal. and 3. M. Anderson. 1979. Decomposition in terrestrial ecosystems. University of Califomia Press. Berkeley. California. USA.

Tamm. C. O.. and A. Pettersson. 1969. Studies on nitrogen mobilization in forest soils. Studia Forestalis Suecia 75.

Tans. P. P. 1978. Carbon 13 and carbon 14 in trees and the atmospheric $\mathrm{CO}_{2}$ increase. Thesis. Rijsuniversiteit te Groningen. Groningen. The Nethertands.

Tans. P., and W. G. Mook. 1980. Past atmospheric CO. levels and the ${ }^{19} \mathrm{C}^{12} \mathrm{C}$ ratios in tree rings. Tellus 32:268283.

Trimble. G. R., and H. W. Lull. 1956. The role of forest humus in watershed management in New England. United
Sutes Forest Service Norheastern Forest Experiment Station Research Paper 85.

Tseplyaev, V. P. 1955. The forests of the USSR. (Translated from Russian by A. Gourevitch.) Daniel Davey. New York. New York. USA.

Tucker, R. P.. and J. R. Richards. 1983. Global deforesta. tion and the nineteenth-century wortd economy. Duke University Press. Durtham. North Carolina. USA.

UNESCO. 1978. Tropical forest ecosystems. a state-of. knowledge report. Natural Resources Research 14. UNES. COUNEP/FAO. Paris. France.

United States Department of Agriculture. 1965. Changes in aquiculture in 26 developing nations. 1948-1963. Foreign Agriculturil Economic Report No. 27. Economic Research Service. United States Department of Agriculture. Washington. D.C.. USA.

1970. Economic progress of agriculture in developing nations. 1950-1968. Foreign Africultural Economsc Report No. 59. Economic Research Service. United States Department of Agriculture. Washington. D.C.. USA.

Wagener. $\mathrm{K}$. 1978. Total anthropogenic $\mathrm{CO}_{2}$ production during the period $1800-1935$ from carbon-13 measurements in tree rings. Radiation and Environmental Biophysics is: 101-111.

Weck. J., and C. Wiebecke. 1961. Weltforstwirschaft und Deutschlands Forstund Holzwirtschaft. BLV Vertagsgeselischaft. Munchen. Germany.

Went. F. W., and N. Start. 1968. Mycomiza. BioScience 18: 1035-1039.

Witkamp. M. 1971. Soils as components of ecosystems. Annual Review of Ecology and Systemacies 2:85-110.

Whitzaker. R. H.. and G. E. Likens. 1973. Carton in the biola. Pages 281-302 in G. M. Woodwell and E. V. Pecan. editors. Carbon and the biosphere. United States Atomic Enerzy Commission. Symposium Series 30. National Technical Information Service. Springfield. Virginia. USA.

Whittlesey. D. 1964. Major agricultural regions. In E. B. Epenshade. Jr., editor. Goode's world atlas. Rand McNally. Chicago. Illinois. USA.

Wilson. A. T. 1978. Fioneer agriculture explosion and $\mathrm{CO}_{2}$ levels in the atmosphere. Nawire 273:40-41.

Wong. C. S. 1978. Atmospheric input of carbon dioxide from burning wood. Science 200: 197-199.

Woodwell. G. M., and R. A. Houghton. 1977. Biotic influences on the wortd arbon budget. Pages 61-72 in W. Stumm. editor. Global chemical cycles and their alteracions by man. Dahlem Konferenzea. Berlin. Germany.

Woodwell. G. M. R. Revetle. G. J. MacDonald, and C. D. Keeting. 1979. The carbon dioxide problem: implications for policy in the management of energy and other resources. Congressional Record. July 26. 1979 125(104): 16. Bultetin of the Atomic Scientists 35187:56-57.

Woodwell. G. M.. R. H. Whittaker. W. A. Reiners. G. E. Likens. C. C. Delwiche. and D. B. Bockin. 1978. The biota and the world carbon budget. Science 199:141-146.

World Bank. 1978. Forestry: sector policy paper. Worid Bank. Washington. D.C.. USA.

Zinke. P. J., S. Sabhasri. and P. Kunstadter. 1978. Soil fertility aspeets of the Lua Forest fallow system of shifting cultivation. Pages 134-159 in P. Kunstadter. E. C. Chapman. and S. Sabhasri. editors. Farmers in the forest: economic development and marginal agriculture in northern Thailand. An East-West Center Book from the East-West Population Institute University Press of Hawaii. Honolulu. Hawaii. USA.

Zon. R.. and W. Sparhawk. 1923. Forest resources of the world. MeGraw-Hill. New York. New York. USA. 
APPENDIX 1

Countries comprising the 10 repions of the world in the terrestrial Carbon Modet.

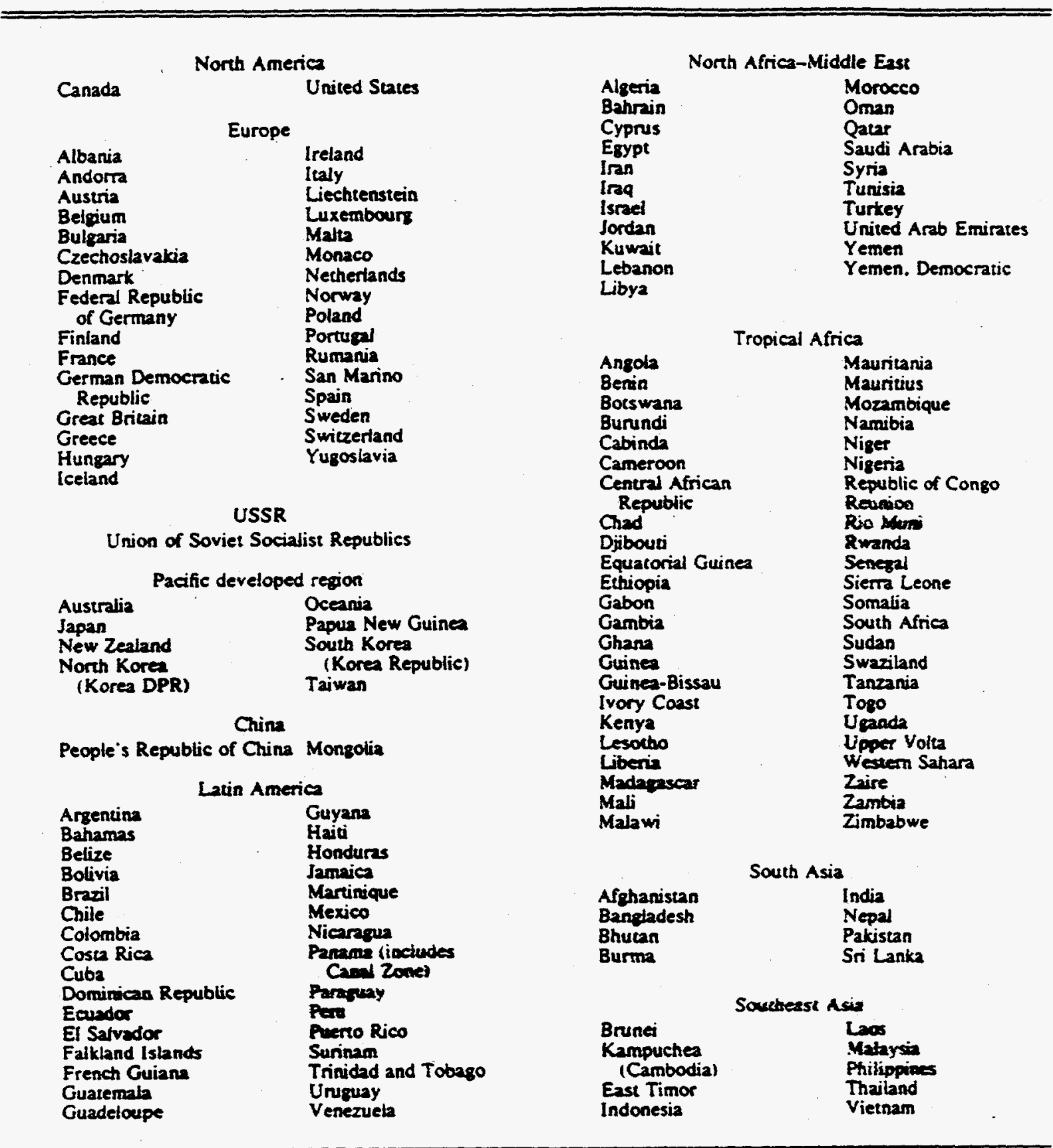


APPENDIX 2

Data used for the population-based estimate. The data given here and in Tables 2 and 3 are the data used in every test. except as otherwise indicated. The model interpolates annual rates linearly between the dates given.

\begin{tabular}{|c|c|c|c|c|c|c|c|c|}
\hline & \multicolumn{8}{|c|}{ Roundwood production (C. $10^{12} \mathrm{~g} / \mathrm{yr}$ ) } \\
\hline & 1700 & 1860 & 1875 & 1900 & 1925 & 1950 & 1970 & 1980 \\
\hline \multicolumn{9}{|l|}{ North Amerio } \\
\hline $\begin{array}{l}\text { Temperate evergreen } \\
\text { Temperate deciduous } \\
\text { Boreal }\end{array}$ & $\begin{array}{l}1.4 \\
1.2 \\
2.3\end{array}$ & $\begin{array}{l}30 \\
26 \\
51\end{array}$ & $\begin{array}{l}37 \\
31 \\
62\end{array}$ & $\begin{array}{l}36 \\
31 \\
61\end{array}$ & $\begin{array}{l}38 \\
32 \\
64\end{array}$ & $\begin{array}{l}33 \\
28 \\
55\end{array}$ & $\begin{array}{l}38 \\
32 \\
63\end{array}$ & $\begin{array}{l}41 \\
35 \\
69\end{array}$ \\
\hline Total & 4.9 & 107 & 130 & 128 & 134 & 116 & 133 & 145 \\
\hline \multicolumn{9}{|l|}{ Europe } \\
\hline $\begin{array}{l}\text { Temperate evergreen } \\
\text { Temperate deciduous } \\
\text { Boreal }\end{array}$ & $\begin{array}{r}12 \\
10 \\
2\end{array}$ & $\frac{26}{22}$ & $\begin{array}{r}29 \\
24 \\
5\end{array}$ & $\begin{array}{r}35 \\
30 \\
6\end{array}$ & $\begin{array}{r}44 \\
37 \\
8\end{array}$ & $\begin{array}{r}41 \\
35 \\
7\end{array}$ & $\begin{array}{r}49 \\
41 \\
8\end{array}$ & $\begin{array}{r}44 \\
38 \\
8\end{array}$ \\
\hline Total & 24 & 53 & 58 & 71 & 89 & 83 & 98 & 90 \\
\hline \multicolumn{9}{|l|}{ USSR } \\
\hline $\begin{array}{l}\text { Temperate evergreen } \\
\text { Temperate deciduous } \\
\text { Boreal }\end{array}$ & $\begin{array}{l}1.7 \\
2.5 \\
8.5\end{array}$ & $\begin{array}{r}6 \\
8 \\
27\end{array}$ & $\begin{array}{r}7 \\
10 \\
31\end{array}$ & $\begin{array}{r}9 \\
14 \\
46\end{array}$ & $\begin{array}{l}10 \\
15 \\
51\end{array}$ & $\begin{array}{l}19 \\
28 \\
95\end{array}$ & $\begin{array}{r}23 \\
111\end{array}$ & $\begin{array}{r}23 \\
33 \\
112\end{array}$ \\
\hline Total & 14 & 41 & 48 & 69 & 76 & 142 & 167 & 168 \\
\hline \multicolumn{9}{|l|}{ Pacific developed. } \\
\hline $\begin{array}{l}\text { Tropical moist } \\
\text { Temperate evergreen } \\
\text { Temperate deciduous }\end{array}$ & $\begin{array}{l}3.8 \\
4.5 \\
1.2\end{array}$ & $\begin{array}{l}5 \\
6 \\
1\end{array}$ & $\begin{array}{l}5 \\
6 \\
2\end{array}$ & $\begin{array}{l}7 \\
8 \\
2\end{array}$ & $\stackrel{9}{11}$ & $\begin{array}{r}12 \\
14 \\
4\end{array}$ & $\begin{array}{r}12 \\
13 \\
3\end{array}$ & $\begin{array}{l}10 \\
12 \\
3\end{array}$ \\
\hline Tocal & 9.5 & 12 & 13 & 17 & 23 & 39 & 28 & 25 \\
\hline \multicolumn{9}{|l|}{ China } \\
\hline $\begin{array}{l}\text { Tropical moist } \\
\text { Temperate evergreen } \\
\text { Temperate deciduous }\end{array}$ & $\begin{array}{l}0.8 \\
3.7 \\
4.6\end{array}$ & $\begin{array}{r}2 \\
10 \\
12\end{array}$ & $\begin{array}{l}2 \\
10 \\
12\end{array}$ & $\frac{2}{11}$ & $\begin{array}{l}3 \\
12 \\
15\end{array}$ & $\begin{array}{l}3 \\
13 \\
16\end{array}$ & $\frac{5}{27}$ & $\begin{array}{r}5 \\
25 \\
31\end{array}$ \\
\hline Total & 9.1 & 24 & 24 & 36 & 30 & 32 & 54 & 61 \\
\hline \multicolumn{9}{|l|}{ Latin America } \\
\hline $\begin{array}{l}\text { Tropical moist } \\
\text { Temperate evergreen } \\
\text { Temperate deciduous }\end{array}$ & $\begin{array}{l}2.3 \\
0.4 \\
0.5\end{array}$ & $\begin{array}{l}7 \\
1 \\
1\end{array}$ & $\begin{array}{l}8 \\
2 \\
1\end{array}$ & $\frac{12}{2}$ & $\begin{array}{r}19 \\
4 \\
3\end{array}$ & $\begin{array}{r}32 \\
6 \\
6\end{array}$ & $\begin{array}{l}54 \\
11 \\
10\end{array}$ & $\begin{array}{l}62 \\
12 \\
11\end{array}$ \\
\hline Total & 3.2 & 9 & II & 16 & 26 & 44 & 75 & 85 \\
\hline \multicolumn{9}{|l|}{ North Africa-Middle East } \\
\hline $\begin{array}{l}\text { Tropical moist } \\
\text { Temperate evergreen }\end{array}$ & $\begin{array}{l}0.9 \\
0.5\end{array}$ & 1 & 1 & $\frac{2}{1}$ & 2 & $\begin{array}{l}3 \\
2\end{array}$ & $\begin{array}{l}6 \\
3\end{array}$ & $\begin{array}{l}7 \\
4\end{array}$ \\
\hline Tocal & 1.4 & 2 & 2 & 3 & 3 & $s$ & 9 & 11 \\
\hline \multicolumn{9}{|l|}{ Tropical Africa } \\
\hline $\begin{array}{l}\text { Tropical moist } \\
\text { Tropical seasonal }\end{array}$ & 119 & $\begin{array}{l}13 \\
14\end{array}$ & $\begin{array}{l}14 \\
16\end{array}$ & $\begin{array}{l}16 \\
18\end{array}$ & $\begin{array}{l}20 \\
23\end{array}$ & $\begin{array}{l}30 \\
33\end{array}$ & $\begin{array}{l}46 \\
52\end{array}$ & $\begin{array}{l}54 \\
60\end{array}$ \\
\hline Tocal & 20 & 27 & 30 & 34 & 43 & 63 & 98 & 114 \\
\hline \multicolumn{9}{|l|}{ South Asia } \\
\hline $\begin{array}{l}\text { Tropical moist } \\
\text { Tropical seasonal }\end{array}$ & 1.2 & 21 & 22 & 25 & 28 & 38 & Si & 62 \\
\hline Total & is & 23 & 24 & 27 & 30 & 41 & 56 & 67 \\
\hline \multicolumn{9}{|l|}{ Southeast Asia } \\
\hline $\begin{array}{l}\text { Tropical moist } \\
\text { Tropical seasonal }\end{array}$ & $\begin{array}{l}4.1 \\
0.7\end{array}$ & $\begin{array}{l}8 \\
1\end{array}$ & $\begin{array}{r}10 \\
2\end{array}$ & $\begin{array}{r}15 \\
3\end{array}$ & 22 & $\begin{array}{r}34 \\
6\end{array}$ & $\begin{array}{l}61 \\
10\end{array}$ & $\begin{array}{l}76 \\
13\end{array}$ \\
\hline Total & 4.8 & 9 & 12 & 18 & 26 & 40 & 71 & 89 \\
\hline
\end{tabular}


APPENDIX 2

Continued.

\begin{tabular}{|c|c|c|c|c|c|c|}
\hline & \multicolumn{6}{|c|}{ Fraction of roundwood assigned to decay pools } \\
\hline & 1700 & 1875 & 1900 & 1925 & 1950 & 1980 \\
\hline \multicolumn{7}{|c|}{ North America } \\
\hline $\begin{array}{l}1 \mathrm{yr} \\
10 \mathrm{yr} \\
100 \mathrm{yr}\end{array}$ & $\begin{array}{l}0.50 \\
0.20 \\
0.30\end{array}$ & $\begin{array}{l}0.44 \\
0.22 \\
0.34\end{array}$ & $\begin{array}{l}0.40 \\
0.24 \\
0.36\end{array}$ & $\begin{array}{l}0.30 \\
0.28 \\
0.42\end{array}$ & $\begin{array}{l}0.20 \\
0.32 \\
0.48\end{array}$ & $\begin{array}{l}0.04 \\
0.38 \\
0.38\end{array}$ \\
\hline \multicolumn{7}{|l|}{ Europe } \\
\hline $\begin{array}{l}1 \mathrm{yr} \\
10 \mathrm{yr} \\
100 \mathrm{yr}\end{array}$ & $\begin{array}{l}0.50 \\
0.20 \\
0.30\end{array}$ & $\begin{array}{l}0.50 \\
0.20 \\
0.30\end{array}$ & $\begin{array}{l}0.50 \\
0.20 \\
0.30\end{array}$ & $\begin{array}{l}0.48 \\
0.21 \\
0.31\end{array}$ & $\begin{array}{l}0.42 \\
0.23 \\
0.35\end{array}$ & $\begin{array}{l}0.18 \\
0.33 \\
0.49\end{array}$ \\
\hline \multicolumn{7}{|l|}{ USSR } \\
\hline $\begin{array}{l}1 \mathrm{yr} \\
10 \mathrm{yr} \\
100 \mathrm{yr}\end{array}$ & $\begin{array}{l}0.65 \\
0.14 \\
0.21\end{array}$ & $\begin{array}{l}0.65 \\
0.14 \\
0.21\end{array}$ & $\begin{array}{l}0.65 \\
0.14 \\
0.21\end{array}$ & $\begin{array}{l}0.46 \\
0.22 \\
0.32\end{array}$ & $\begin{array}{l}0.41 \\
0.24 \\
0.35\end{array}$ & $\begin{array}{l}0.22 \\
0.31 \\
0.47\end{array}$ \\
\hline \multicolumn{7}{|c|}{ Pacific developed } \\
\hline $\begin{array}{l}1 \mathrm{yr} \\
10 \mathrm{yr} \\
100 \mathrm{yr}\end{array}$ & $\begin{array}{l}0.81 \\
0.08 \\
0.11\end{array}$ & $\begin{array}{l}0.81 \\
0.08 \\
0.11\end{array}$ & $\begin{array}{l}0.81 \\
0.08 \\
0.11\end{array}$ & $\begin{array}{l}0.81 \\
0.08 \\
0.11\end{array}$ & $\begin{array}{l}0.42 \\
0.23 \\
0.35\end{array}$ & $\begin{array}{l}0.27 \\
0.29 \\
0.44\end{array}$ \\
\hline \multicolumn{7}{|l|}{ China } \\
\hline $\begin{array}{l}1 \mathrm{yr} \\
10 \mathrm{yr} \\
100 \mathrm{yr}\end{array}$ & $\begin{array}{l}0.90 \\
0.04 \\
0.06\end{array}$ & $\begin{array}{l}0.90 \\
0.04 \\
0.06\end{array}$ & $\begin{array}{l}0.90 \\
0.04 \\
0.06\end{array}$ & $\begin{array}{l}0.86 \\
0.06 \\
0.08\end{array}$ & $\begin{array}{l}0.80 \\
0.08 \\
0.12\end{array}$ & $\begin{array}{l}0.75 \\
0.10 \\
0.15\end{array}$ \\
\hline \multicolumn{7}{|c|}{ Latin America } \\
\hline $\begin{array}{l}1 \mathrm{yr} \\
10 \mathrm{yr} \\
100 \mathrm{yr}\end{array}$ & $\begin{array}{l}0.90 \\
0.04 \\
0.06\end{array}$ & $\begin{array}{l}0.90 \\
0.04 \\
0.06\end{array}$ & $\begin{array}{l}0.90 \\
0.04 \\
0.06\end{array}$ & $\begin{array}{l}0.90 \\
0.04 \\
0.06\end{array}$ & $\begin{array}{l}0.84 \\
0.06 \\
0.10\end{array}$ & $\begin{array}{l}0.82 \\
0.07 \\
0.11\end{array}$ \\
\hline \multicolumn{7}{|c|}{ North Africa-Middle East } \\
\hline $\begin{array}{l}1 \mathrm{yr} \\
10 \mathrm{yr} \\
100 \mathrm{yr}\end{array}$ & $\begin{array}{l}0.90 \\
0.04 \\
0.06\end{array}$ & $\begin{array}{l}0.90 \\
0.04 \\
0.06\end{array}$ & $\begin{array}{l}0.90 \\
0.04 \\
0.06\end{array}$ & $\begin{array}{l}0.87 \\
0.05 \\
0.08\end{array}$ & $\begin{array}{l}0.75 \\
0.10 \\
0.15\end{array}$ & $\begin{array}{l}0.63 \\
0.15 \\
0.22\end{array}$ \\
\hline \multicolumn{7}{|c|}{ Tropical Africa } \\
\hline $\begin{array}{l}1 \mathrm{yr} \\
10 \mathrm{yr} \\
100 \mathrm{yr}\end{array}$ & $\begin{array}{l}0.93 \\
0.03 \\
0.04\end{array}$ & $\begin{array}{l}0.93 \\
0.03 \\
0.04\end{array}$ & $\begin{array}{l}0.93 \\
0.03 \\
0.04\end{array}$ & $\begin{array}{l}0.91 \\
0.04 \\
0.05\end{array}$ & $\begin{array}{l}0.90 \\
0.04 \\
0.06\end{array}$ & $\begin{array}{l}0.87 \\
0.05 \\
0.08\end{array}$ \\
\hline \multicolumn{7}{|c|}{ South Asia } \\
\hline $\begin{array}{l}1 \mathrm{yr} \\
10 \mathrm{yr} \\
100 \mathrm{yr}\end{array}$ & $\begin{array}{l}0.92 \\
0.03 \\
0.05\end{array}$ & $\begin{array}{l}0.92 \\
0.03 \\
0.05\end{array}$ & $\begin{array}{l}0.92 \\
0.03 \\
0.05\end{array}$ & $\begin{array}{l}0.92 \\
0.03 \\
0.05\end{array}$ & $\begin{array}{l}0.92 \\
0.03 \\
0.05\end{array}$ & $\begin{array}{l}0.90 \\
0.04 \\
0.06\end{array}$ \\
\hline \multicolumn{7}{|c|}{ Southeast Asia } \\
\hline $\begin{array}{l}1 \mathrm{yr} \\
10 \mathrm{yr} \\
100 \mathrm{yr}\end{array}$ & $\begin{array}{l}0.90 \\
0.04 \\
0.06\end{array}$ & $\begin{array}{l}0.90 \\
0.04 \\
0.06\end{array}$ & $\begin{array}{l}0.90 \\
0.04 \\
0.06\end{array}$ & $\begin{array}{l}0.85 \\
0.06 \\
0.09\end{array}$ & $\begin{array}{l}0.82 \\
0.07 \\
0.11\end{array}$ & $\begin{array}{l}0.75 \\
0.10 \\
0.15\end{array}$ \\
\hline
\end{tabular}




\section{APPENDIX 2}

Continued.

\begin{tabular}{|c|c|c|c|c|c|c|c|}
\hline \multirow[b]{2}{*}{ North America } & \multicolumn{7}{|c|}{ Conversion of land to agriculture (10 ha/yr) } \\
\hline & $1700-1849$ & $1850-1889$ & $1890-1927$ & $1928-1949$ & 1950 & 1970 & 1980 \\
\hline $\begin{array}{l}\text { Temperate evergreen } \\
\text { Temperate deciduous } \\
\text { Boreal } \\
\text { Temperate woodland and shrub } \\
\text { Temperate grassland }\end{array}$ & $\begin{array}{l}0.09 \\
0.21 \\
0 \\
0 \\
0\end{array}$ & $\begin{array}{l}0.09 \\
0.09 \\
0.03 \\
0.09 \\
1.2\end{array}$ & $\begin{array}{l}0.14 \\
0.14 \\
0.05 \\
0.14 \\
1.8\end{array}$ & $\begin{array}{l}0.03 \\
0.03 \\
0.01 \\
0.03 \\
0.40\end{array}$ & $\begin{array}{l}0 \\
0 \\
0 \\
0 \\
0\end{array}$ & $\begin{array}{l}-0.09 \\
-0.09 \\
0 \\
0 \\
-0.02\end{array}$ & $\begin{array}{l}0 \\
0 \\
0 \\
0 \\
0\end{array}$ \\
\hline Total & 0.30 & 1.5 & 2.3 & 0.50 & 0 & -0.18 & 0 \\
\hline Europe & $1700-1869$ & $1870-1959$ & 1960 & 1970 & 1980 & & \\
\hline $\begin{array}{l}\text { Temperate evergreen } \\
\text { Temperate deciduous } \\
\text { Boreal } \\
\text { Temperate grassland }\end{array}$ & $\begin{array}{l}0.06 \\
0.06 \\
0.05 \\
0.26\end{array}$ & $\begin{array}{l}0.02 \\
0.02 \\
0.02 \\
0.09\end{array}$ & $\begin{array}{l}0 \\
0 \\
0 \\
0\end{array}$ & $\begin{array}{l}-0.20 \\
-0.20 \\
-0.20 \\
-0.20\end{array}$ & $\begin{array}{l}-0.20 \\
-0.20 \\
-0.20 \\
-0.20\end{array}$ & & \\
\hline Total & 0.43 & 0.15 & 0 & -0.80 & -0.80 & & \\
\hline USSR & $1700-1869$ & $\cdot 1870-1909$ & $1910-1937$ & $1938-1969$ & $1970-1980$ & & \\
\hline $\begin{array}{l}\text { Temperate deciduous } \\
\text { Boreal } \\
\text { Temperate woodland and shrub } \\
\text { Temperate grassland }\end{array}$ & $\begin{array}{l}0.18 \\
0.02 \\
0.08 \\
0.12\end{array}$ & $\begin{array}{l}0.36 \\
0.07 \\
0.29 \\
0.72\end{array}$ & $\begin{array}{l}0.40 \\
0.08 \\
0.32 \\
0.80\end{array}$ & $\begin{array}{l}0.22 \\
0.04 \\
0.18 \\
0.44\end{array}$ & $\begin{array}{l}0 \\
0 \\
0 \\
0\end{array}$ & & \\
\hline Total & 0.40 & 1.5 & 1.60 & 0.88 & 0 & & \\
\hline Pacific developed & $1700-1869$ & $1870-1949$ & $1950-1969$ & $1970-1980$ & & & \\
\hline $\begin{array}{l}\text { Tropical moist } \\
\text { Temperate evergreen } \\
\text { Temperate deciduous } \\
\text { Tropical woodiand and shrub } \\
\text { Tropical grassland }\end{array}$ & $\begin{array}{l}0.0011 \\
0 \\
0 \\
0.0019 \\
0.0044\end{array}$ & $\begin{array}{l}0.038 \\
0 \\
0 \\
0.06 \\
0.15\end{array}$ & $\begin{array}{l}0.22 \\
0 \\
0 \\
0.36 \\
0.86\end{array}$ & $\begin{array}{l}0.03 \\
0 \\
0 \\
0.05 \\
0.12\end{array}$ & & & \\
\hline Total & 0.0074 & 0.25 & 1.4 & 0.20 & & & \\
\hline China & $1700-1872$ & $1873-1912$ & $1913-1932$ & $1933-1953$ & $1954-1964$ & $1965-1969$ & $1970-1980$ \\
\hline $\begin{array}{l}\text { Tropical moist } \\
\text { Temperate evergreen } \\
\text { Temperate deciduous } \\
\text { Temperate grassiand }\end{array}$ & $\begin{array}{l}0.030 \\
0.046 \\
0.18 \\
0.046\end{array}$ & $\begin{array}{l}0.025 \\
0.038 \\
0.15 \\
0.038\end{array}$ & $\begin{array}{l}0.037 \\
0.055 \\
0.22 \\
0.055\end{array}$ & $\begin{array}{l}0.049 \\
0 \\
0.30 \\
0.15\end{array}$ & $\begin{array}{l}0.11 \\
0 \\
0.47 \\
0.54\end{array}$ & $\begin{array}{l}0.097 \\
0 \\
0.48 \\
0.39\end{array}$ & $\begin{array}{l}0.065 \\
0 \\
0 \\
0.59\end{array}$ \\
\hline Total & 0.30 & 0.25 & 0.37 & 0.49 & 1.1 & 0.97 & 0.65 \\
\hline Latin America & $1700-1859$ & $1860-1874$ & $1875-1899$ & $1900-1924$ & $1925-1949$ & $1950-1964$ & $1965-1980$ \\
\hline $\begin{array}{l}\text { Tropical moist } \\
\text { Temperate evergreen } \\
\text { Temperate deciduous } \\
\text { Tropical grassland } \\
\text { Temperate grassland }\end{array}$ & $\begin{array}{l}0.038 \\
0 \\
0 \\
0 \\
0.037\end{array}$ & $\begin{array}{l}0.10 \\
0 \\
0 \\
0 \\
0.10\end{array}$ & $\begin{array}{l}0.20 \\
0 \\
0 \\
0 \\
0.20\end{array}$ & $\begin{array}{l}0.32 \\
0 \\
0 \\
0 \\
0.32\end{array}$ & $\begin{array}{l}0.74 \\
0 \\
0 \\
0 \\
0.74\end{array}$ & $\begin{array}{l}0.87 \\
0.35 \\
0.18 \\
0.35 \\
0\end{array}$ & $\begin{array}{l}0.96 \\
0.39 \\
0.19 \\
0.39 \\
0\end{array}$ \\
\hline Total & 0.075 & 0.20 & 0.40 & 0.64 & 1.5 & 1.8 & 1.9 \\
\hline North Africa-Middle East & $1700-1859$ & $1860-1899$ & $1900-1924$ & $1925-1949$ & $1950-1964$ & $1965-1980$ & \\
\hline $\begin{array}{l}\text { Tropical moist } \\
\text { Temperate evergreen } \\
\text { Tropical grassland } \\
\text { Desert serub }\end{array}$ & $\begin{array}{l}0.010 \\
0.014 \\
0.024 \\
0\end{array}$ & $\begin{array}{l}0.044 \\
0.066 \\
0.11 \\
0\end{array}$ & $\begin{array}{l}0.060 \\
0.091 \\
0.15 \\
0\end{array}$ & $\begin{array}{l}0.17 \\
0.15 \\
0.41 \\
0.10\end{array}$ & $\begin{array}{l}0.13 \\
0 \\
0.64 \\
0.51\end{array}$ & $\begin{array}{l}0.15 \\
0 \\
0.73 \\
0.59\end{array}$ & \\
\hline Total & 0.048 & 0.22 & 0.30 & 0.83 & 1.3 & 1.5 & \\
\hline Tropical Africa & $1700-1859$ & $1860-1874$ & $1875-1899$ & $1900-1924$ & $1925-1949$ & $1950-1964$ & $196 \leq-1980$ \\
\hline $\begin{array}{l}\text { Tropical moist } \\
\text { Tropical seasonal } \\
\text { Tropical woodland and shrub } \\
\text { Tropical grassland }\end{array}$ & $\begin{array}{l}0.018 \\
0.004 \\
0.031 \\
0.035\end{array}$ & $\begin{array}{l}0.053 \\
0.013 \\
0.093 \\
0.11\end{array}$ & $\begin{array}{l}0.08 \\
0.02 \\
0.14 \\
0.16\end{array}$ & $\begin{array}{l}0.15 \\
0.038 \\
0.27 \\
0.30\end{array}$ & $\begin{array}{l}0.34 \\
0.084 \\
0.59 \\
0.67\end{array}$ & $\begin{array}{l}1.3 \\
0.13 \\
0.77 \\
0.38\end{array}$ & $\begin{array}{l}1.6 \\
0.16 \\
0.95 \\
0.48\end{array}$ \\
\hline Total & 0.088 & 0.27 & 0.40 & 0.76 & 1.7 & 2.6 & 3.2 \\
\hline South Asia & $1700-1859$ & $1860-1899$ & $1900-1924$ & $1925-1949$ & $1950-1964$ & $1965-1980$ & \\
\hline $\begin{array}{l}\text { Tropical moist } \\
\text { Tropical seasonal } \\
\text { Tropical woodland and shrub } \\
\text { Tropical grassland }\end{array}$ & $\begin{array}{l}0.004 \\
0.038 \\
0.072 \\
0.006\end{array}$ & $\begin{array}{l}0.012 \\
0.13 \\
0.24 \\
0.020\end{array}$ & $\begin{array}{l}0.014 \\
0.15 \\
0.28 \\
0.023\end{array}$ & $\begin{array}{l}0.042 \\
0.45 \\
0.84 \\
0.070\end{array}$ & $\begin{array}{l}0.049 \\
0.53 \\
0.98 \\
0.082\end{array}$ & $\begin{array}{l}0.096 \\
1.0 \\
1.9 \\
0.16\end{array}$ & \\
\hline Total & 0.12 & 0.40 & 0.47 & 1.40 & 1.6 & 3.2 & \\
\hline
\end{tabular}


APPENDIX 2

Continued.

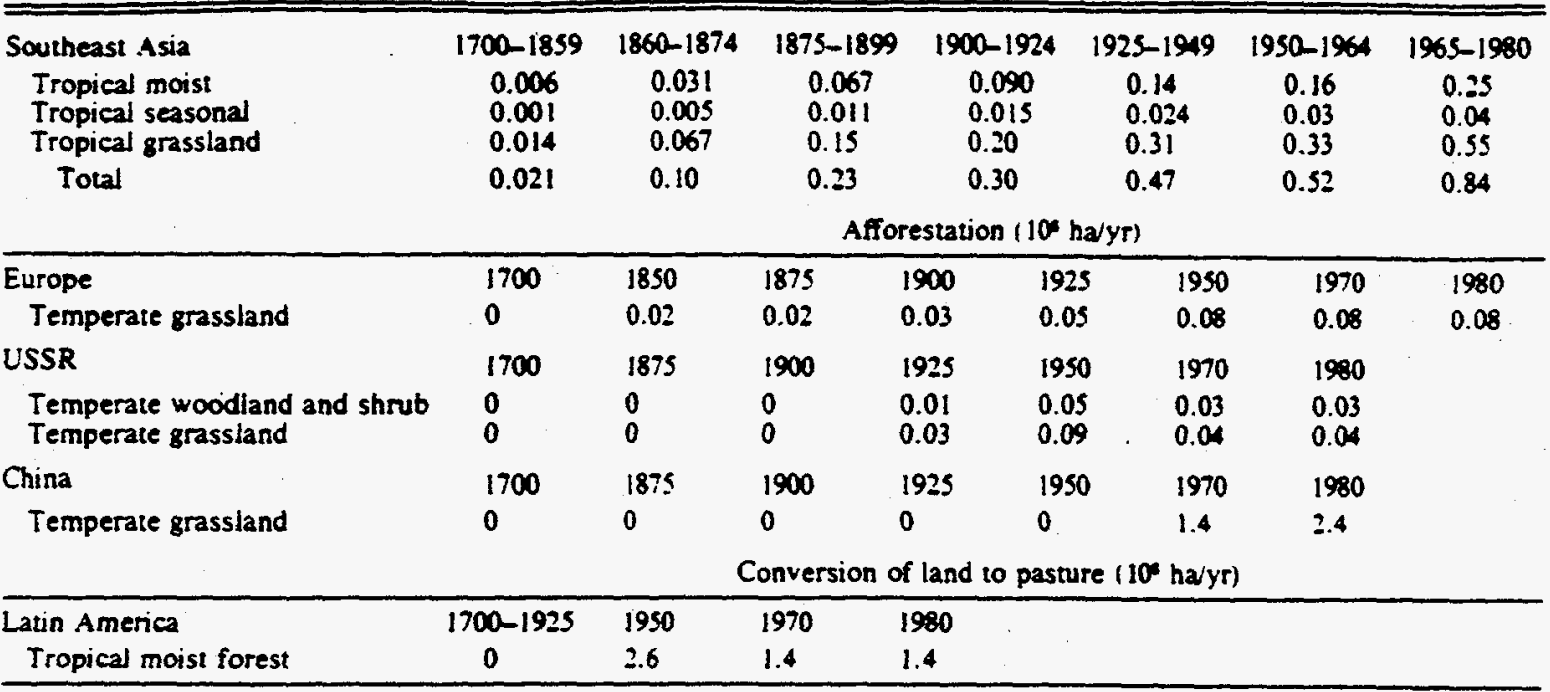

\section{APPENDIX 3}

Data used for the estimate based on the Production Yearbooks of the FAO. All of the data used in this analysis. except for the clearing rates given here, are the same as used in the population-based estimate (Tables 2 and 3 . Appendix 2). Daca are rounded off to no more than two nonzero digits.

\begin{tabular}{|c|c|c|c|c|c|c|}
\hline \multirow[b]{2}{*}{ Latin America } & \multicolumn{6}{|c|}{ Annual rates for the conversion of natural ecosystems to agriculnure 110 hayr) } \\
\hline & & & $1950-1969$ & $1970-1980$ & & \\
\hline $\begin{array}{l}\text { Tropical moist forest } \\
\text { Temperate evergreen forest } \\
\text { Temperate deciduous forest } \\
\text { Tropical grassland }\end{array}$ & & & $\begin{array}{l}1.2 \\
0.49 \\
0.24 \\
0.49\end{array}$ & $\begin{array}{l}0.81 \\
0.33 \\
0.16 \\
0.33\end{array}$ & & \\
\hline Total & & & 2.4 & 1.6 & & \\
\hline North Africa-Middle East & & & $1950-1964$ & $1965-1980$ & & \\
\hline $\begin{array}{l}\text { Tropical moist forest } \\
\text { Temperale evergreen forest } \\
\text { Tropical grassland } \\
\text { Desert and scrub }\end{array}$ & & & $\begin{array}{l}0.22 \\
0 \\
0.54 \\
0.33\end{array}$ & $\begin{array}{l}0.07 \\
0 \\
0.17 \\
0.10\end{array}$ & & \\
\hline Total & & & 1.1 & 0.34 & & \\
\hline Tropical Africa & & $1950-1964$ & $1965-1969$ & $1970-1960$ & & \\
\hline $\begin{array}{l}\text { Tropical moist forest } \\
\text { Tropical seasonal forest } \\
\text { Tropical woodland and shrubland } \\
\text { Tropical grassland }\end{array}$ & & $\begin{array}{l}1.5 \\
0.16 \\
0.93 \\
0.46\end{array}$ & $\begin{array}{l}0.94 \\
0.94 \\
0.56 \\
0.28\end{array}$ & $\begin{array}{l}0 \\
0 \\
0 \\
0\end{array}$ & & \\
\hline Tocal & & 3.1 & 2.7 & 0 & & \\
\hline South Asia & $1860-1910$ & $1911-1940$ & $1941-1950$ & $1951-1955$ & $1956-1965$ & $1966-1980$ \\
\hline $\begin{array}{l}\text { Tropical moist forest } \\
\text { Tropical seasonal forest } \\
\text { Tropical woodland and shrubland } \\
\text { Tropical grassland }\end{array}$ & $\begin{array}{l}0.017 \\
0.18 \\
0.34 \\
0.028\end{array}$ & $\begin{array}{l}0 \\
0 \\
0 \\
0\end{array}$ & $\begin{array}{l}0.25 \\
2.7 \\
5.0 \\
0.41\end{array}$ & $\begin{array}{l}0.22 \\
2.3 \\
4.3 \\
0.36\end{array}$ & $\begin{array}{l}0.033 \\
0.35 \\
0.66 \\
0.055\end{array}$ & $\begin{array}{l}0.018 \\
0.19 \\
0.33 \\
0.03\end{array}$ \\
\hline Total & 0.57 & 0 & 8.3 & 7.2 & 1.1 & 0.57 \\
\hline Southeast Asia & & & $1950-1964$ & $1965-1980$ & & \\
\hline $\begin{array}{l}\text { Tropical moist forest } \\
\text { Tropical seasonal forest } \\
\text { Tropical grassland }\end{array}$ & & & $\begin{array}{l}0.35 \\
0.059 \\
0.76\end{array}$ & $\begin{array}{l}0.22 \\
0.037 \\
0.49\end{array}$ & & \\
\hline Total & & & 1.2 & 0.75 & & \\
\hline
\end{tabular}




\section{APPENDIX 4}

Data used for the Myers estimate. All of the information used in this analysis. exeept for the data given here. are the same as used in the population-based estimate (Tables $\geq$ and 3. Appendix 2). The model interpolates linearty between the dates given.

\begin{tabular}{|c|c|c|c|}
\hline \multicolumn{4}{|c|}{$\begin{array}{l}\text { Annual rates for the conversion of natural } \\
\text { ecosystems to agriculture }\left(10^{\circ} \text { ha/yr) }\right.\end{array}$} \\
\hline & 1965 & 1970 & 1980 \\
\hline \multicolumn{4}{|l|}{ Latin Ameria } \\
\hline $\begin{array}{l}\text { Tropical moist forest } \\
\text { Temperate evergreen forest } \\
\text { Temperate deciduous forest } \\
\text { Tropical grassland } \\
\text { Temperale grassland }\end{array}$ & $\begin{array}{l}0.96 \\
0.39 \\
0.19 \\
0.39 \\
0\end{array}$ & $\begin{array}{l}1.3 \\
0.40 \\
0.20 \\
0.06 \\
0\end{array}$ & $\begin{array}{l}3.4 \\
0 \\
0 \\
0 \\
0\end{array}$ \\
\hline Total & 1.9 & 2.0 & 3.4 \\
\hline \multicolumn{4}{|l|}{ Tropical Africa } \\
\hline $\begin{array}{l}\text { Tropical moist forest } \\
\text { Tropical seasonal forest } \\
\text { Tropical woodland and shrubland } \\
\text { Tropical grassland }\end{array}$ & $\begin{array}{l}1.6 \\
0.16 \\
0.95 \\
0.48\end{array}$ & $\begin{array}{l}1.7 \\
0.04 \\
0.21 \\
0.10\end{array}$ & $\begin{array}{l}2.7 \\
0 \\
0 \\
0\end{array}$ \\
\hline Tocal & 3.2 & 2.0 & 2.7 \\
\hline \multicolumn{4}{|l|}{ Southeast Asia } \\
\hline $\begin{array}{l}\text { Tropical moist forest } \\
\text { Tropical seasonal forest } \\
\text { Tropical grassland }\end{array}$ & $\begin{array}{l}0.25 \\
0.04 \\
0.55\end{array}$ & $\begin{array}{l}2.0 \\
0 \\
0\end{array}$ & $\begin{array}{l}5.7 \\
0 \\
0\end{array}$ \\
\hline Total & 0.84 & 2.0 & 5.7 \\
\hline \multicolumn{4}{|c|}{$\begin{array}{l}\text { Rates of harvest (only tropical moist } \\
\left.\text { forests harvested) (C. } 10^{22} g / y r\right)\end{array}$} \\
\hline & 1950 & 1970 & 1980 \\
\hline $\begin{array}{l}\text { Latin America } \\
\text { Tropical Afrie } \\
\text { Southeast Asia }\end{array}$ & $\begin{array}{l}32 \\
30 \\
34\end{array}$ & $\begin{array}{l}81 \\
69 \\
92\end{array}$ & $\begin{array}{l}124 \\
108 \\
152\end{array}$ \\
\hline \multicolumn{4}{|c|}{$\begin{array}{l}\text { Rates for the conversion of natural } \\
\text { ecosystems to pasture }\end{array}$} \\
\hline Latin Americe & 1950 & 1970 & 1980 \\
\hline Tropical moist forest & 0.2 & 1.0 & 2.0 \\
\hline
\end{tabular}

APPENDIX 5

Data used to test the sensitivity of carbon fux to the historical course of ciearing for agriculture. The values given here were derived from rates given by Richards (1982). All of the dae used in this test. except for the data presented here. are in Tables 2 and 3 and Appendix 2 .

\begin{tabular}{lclr}
\hline & Area in agriculture in 1700 AD (10 ha) & \\
\hline North America & 0 & Latin America & 0 \\
Europe & 100 & North Africa-Middle East & 35 \\
USSR & 50 & Tropical Africa & 3 \\
Pacific developed & 3 & South Asia & 25 \\
China & 45 & Southeast Asia & 5 \\
\hline
\end{tabular}


APPENDIX 3

Continued.

\begin{tabular}{|c|c|c|c|c|c|}
\hline \multicolumn{6}{|c|}{$\begin{array}{l}\text { Rates for the conversion of natural ecosystems to agriculaure ( } 10^{\circ} \text { ha/yr) } \\
\text { Negative values indicate net nies of agriculural abandonment }\end{array}$} \\
\hline North America & $1700-1859$ & $1860-1919$ & $1920-1949$ & $1950-1980$ & \\
\hline $\begin{array}{l}\text { Temperate evergreen forest } \\
\text { Temperate deciduous focest } \\
\text { Borel forest } \\
\text { Temperate woodland and shrubland } \\
\text { Temperate grassland }\end{array}$ & $\begin{array}{l}0.047 \\
0.11 \\
0.0 \\
0.0 \\
0.0\end{array}$ & $\begin{array}{l}0.17 \\
0.17 \\
0.058 \\
0.17 \\
2.3\end{array}$ & $\begin{array}{l}0.010 \\
0.010 \\
0.003 \\
0.010 \\
0.13\end{array}$ & $\begin{array}{c}-0.084 \\
-0.084 \\
0.0 \\
0.0 \\
0.0\end{array}$ & \\
\hline Toul & 0.16 & 2.8 & 0.16 & -0.17 & \\
\hline Europe & $1700-1859$ & $1860-1919$ & $1920-1959$ & $1960-1980$ & \\
\hline $\begin{array}{l}\text { Temperate evergreen forest } \\
\text { Temperale deciduous forest } \\
\text { Boreal forest } \\
\text { Temperate grassland }\end{array}$ & $\begin{array}{l}0.018 \\
0.018 \\
0.016 \\
0.079\end{array}$ & $\begin{array}{l}0.035 \\
0.035 \\
0.030 \\
0.15\end{array}$ & $\begin{array}{l}0.060 \\
0.060 \\
0.051 \\
0.25\end{array}$ & $\begin{array}{c}-0.32 \\
-0.32 \\
0.0 \\
0.0\end{array}$ & \\
\hline Tocal & 0.13 & 0.25 & 0.42 & -0.64 & \\
\hline USSR & $1700-1859$ & $1860-1919$ & $1920-1969$ & $1970-1980$ & \\
\hline $\begin{array}{l}\text { Temperace deciduous forest } \\
\text { Boreal forest } \\
\text { Temperate woodland and shrubland } \\
\text { Temperate grassland }\end{array}$ & $\begin{array}{l}0.037 \\
0.004 \\
0.016 \\
0.024\end{array}$ & $\begin{array}{l}0.23 \\
0.047 \\
0.19 \\
0.47\end{array}$ & $\begin{array}{l}0.58 \\
0.12 \\
0.46 \\
1.2\end{array}$ & $\begin{array}{l}0.0 \\
0.0 \\
0.0 \\
0.0\end{array}$ & \\
\hline Tocal & 0.081 & 0.94 & 2.4 & 0.0 & \\
\hline Pacific developed & $1700-1859$ & $1860-1919$ & $1930-1949$ & $1950-1969$ & $1970-1980$ \\
\hline $\begin{array}{l}\text { Tropical moist forest } \\
\text { Tropical woodland and shrubland } \\
\text { Tropical grassland }\end{array}$ & $\begin{array}{l}0.0009 \\
0.002 \\
0.004\end{array}$ & $\begin{array}{l}0.040 \\
0.067 \\
0.16\end{array}$ & $\begin{array}{l}0.070 \\
0.12 \\
0.28\end{array}$ & $\begin{array}{l}0.26 \\
0.44 \\
1.0\end{array}$ & $\begin{array}{l}0.045 \\
0.075 \\
0.18\end{array}$ \\
\hline Toul & 0.006 & 0.27 & 0.47 & 1.7 & 0.30 \\
\hline China & $1700-1859$ & $1860-1919$ & $1920-1949$ & $1950-1980$ & \\
\hline $\begin{array}{l}\text { Tropical moist forest } \\
\text { Temperate evergreen forest } \\
\text { Temperate deciduous forest } \\
\text { Tropical grasland }\end{array}$ & $\begin{array}{l}0.003 \\
0.004 \\
0.015 \\
0.004\end{array}$ & $\begin{array}{l}0.058 \\
0.087 \\
0.35 \\
0.067\end{array}$ & $\begin{array}{l}0.023 \\
0.0 \\
0.14 \\
0.070\end{array}$ & $\begin{array}{l}0.13 \\
0.0 \\
0.52 \\
0.65\end{array}$ & \\
\hline Toul & 0.025 & 0.58 & 0.23 & 1.3 & \\
\hline Latin America & $1700-1859$ & $1860-1919$ & $1920-1949$ & $1950-1964$ & $1965-1980$ \\
\hline $\begin{array}{l}\text { Tropical moist forest } \\
\text { Temperate evergreen forest } \\
\text { Temperate deciduous forest } \\
\text { Tropical gressiand } \\
\text { Temperate grassiand }\end{array}$ & $\begin{array}{l}0.0 \\
0.0 \\
0.0 \\
0.0 \\
0.0\end{array}$ & $\begin{array}{l}0.43 \\
0.0 \\
0.0 \\
0.0 \\
0.43\end{array}$ & $\begin{array}{l}0.55 \\
0.0 \\
0.0 \\
0.0 \\
0.55\end{array}$ & $\begin{array}{l}0.87 \\
0.35 \\
0.17 \\
0.35 \\
0.0\end{array}$ & $\begin{array}{l}0.96 \\
0.39 \\
0.19 \\
0.39 \\
0.0\end{array}$ \\
\hline Total & 0.0 & 0.86 & 1.1 & 1.7 & 1.9 \\
\hline North Africa-Middle Eass & $1700-1859$ & $1860-1919$ & $1920-1949$ & $1950-1964$ & $1965-1980$ \\
\hline $\begin{array}{l}\text { Tropical moist forest } \\
\text { Temperate evergreen forest } \\
\text { Tropical grasstand } \\
\text { Deser scrub }\end{array}$ & $\begin{array}{l}0.005 \\
0.008 \\
0.013 \\
0.0\end{array}$ & $\begin{array}{l}0.087 \\
0.13 \\
0.22 \\
0.0\end{array}$ & $\begin{array}{l}0.0 \\
0.0 \\
0.0 \\
0.0\end{array}$ & $\begin{array}{l}0.13 \\
0.0 \\
0.64 \\
0.51\end{array}$ & $\begin{array}{l}0.15 \\
0.0 \\
0.74 \\
0.59\end{array}$ \\
\hline Total & 0.025 & 0.44 & 0.0 & 1.3 & 1.5 \\
\hline Tropical Afriea & $1700-1859$ & $1860-1919$ & $1920-1949$ & $1950-1964$ & $1965-1980$ \\
\hline $\begin{array}{l}\text { Tropieal moist forest } \\
\text { Tropical seasonal forest } \\
\text { Tropical woodland and shrubland } \\
\text { Tropical grassland }\end{array}$ & $\begin{array}{l}0.0 \\
0.0 \\
0.0 \\
0.0\end{array}$ & $\begin{array}{l}0.11 \\
0.028 \\
0.20 \\
0.23\end{array}$ & $\begin{array}{l}0.64 \\
0.16 \\
1.1 \\
1.3\end{array}$ & $\begin{array}{l}1.3 \\
0.13 \\
0.77 \\
0.38\end{array}$ & $\begin{array}{l}1.6 \\
0.16 \\
0.95 \\
0.48\end{array}$ \\
\hline Total & 0.0 & 0.57 & 3.2 & 2.6 & 3.2 \\
\hline South Asia & $1700-1859$ & $1860-1919$ & $1920-1949$ & $1950-1964$ & $1965-1980$ \\
\hline $\begin{array}{l}\text { Tropical moist forest } \\
\text { Tropical seasonal forest } \\
\text { Tropical woodland and shrubland } \\
\text { Tropical grassland }\end{array}$ & $\begin{array}{l}0.0004 \\
0.0010 \\
0.0075 \\
0.0006\end{array}$ & $\begin{array}{l}0.044 \\
0.47 \\
0.89 \\
0.074\end{array}$ & $\begin{array}{l}0.050 \\
0.53 \\
1.0 \\
0.083\end{array}$ & $\begin{array}{l}0.049 \\
0.52 \\
0.98 \\
0.082\end{array}$ & $\begin{array}{l}0.096 \\
1.0 \\
1.9 \\
0.16\end{array}$ \\
\hline Total & 0.013 & 1.5 & 1.7 & 1.6 & 3.2 \\
\hline Southeast Asia & $1700-1859$ & $1860-1919$ & $1930-1949$ & $1950-1964$ & $1955-1980$ \\
\hline $\begin{array}{l}\text { Tropical moist forest } \\
\text { Tropical seasonal forest } \\
\text { Tropical grassland }\end{array}$ & $\begin{array}{l}0.0 \\
0.0 \\
0.0\end{array}$ & $\begin{array}{l}0.095 \\
0.016 \\
0.21\end{array}$ & $\begin{array}{l}0.11 \\
0.018 \\
0.24\end{array}$ & $\begin{array}{l}0.16 \\
0.03 \\
0.33\end{array}$ & $\begin{array}{l}0.25 \\
0.04 \\
0.55\end{array}$ \\
\hline Total & 0.0 & 0.32 & 0.37 & 0.52 & 0.84 \\
\hline
\end{tabular}


262

R. A. HOUGHTON ET AL.

Eedopeal Monographs
Vol. 33 . No. 3

APPENDIX 6

Data used to test the sensitivity of carton fix 10 rates of decay. All of the data used in this test, other than the values given here. are in Tables 2 and 3 and Appendix 2 . The values given here were derived from estimates $\alpha$ charcoal produceion given by Seller and Cruizen (1980).

Fraction of carbon in vegetation assigned to decay pools after clearing of forests. The same fractions apply to all types of forests.

\begin{tabular}{ll}
\hline Soil pool & 0.230 \\
$1 \mathrm{yr}$ & 0.270 \\
$10 \mathrm{yr}$ & 0.285 \\
$100 \mathrm{yr}$ & 0.092 \\
$1000 \mathrm{yr}$ & 0.123 \\
Total & 1.000 \\
\hline
\end{tabular}

APPENDIX 7

Data used to test the sensitivity of carton flux to lower amounts of carbon per unit area in vegetation and soil. All dat used in the test. Ocher than the values given here. are in Tables 2 and 3 and Appendix ?. The values given here were derived from estimates of biomass and soil carbon in tropical forests (Brown and Lugo 1980).

\begin{tabular}{lcc}
\hline & $\begin{array}{c}\text { Tropical } \\
\text { moist } \\
\text { forest }\end{array}$ & $\begin{array}{c}\text { Tropical } \\
\text { seasonal } \\
\text { forest }\end{array}$ \\
\hline $\begin{array}{c}\text { Carbon in the vegetation of } \\
\text { undisturbed forests }\end{array}$ & 156 & 84 \\
$\begin{array}{c}\text { Carbon in the vegetation of } \\
\text { secondary forests }\end{array}$ & 117 & 63 \\
$\begin{array}{l}\text { Carbon in the soil of } \\
\text { undisturbed forests }\end{array}$ & 84 & 40 \\
$\begin{array}{l}\text { Carbon in the soil of } \\
\text { secondary forests }\end{array}$ & 63 & 30 \\
$\begin{array}{l}\text { Minimum carbon content of } \\
\text { soil following harvest }\end{array}$ & 55 & 26 \\
$\begin{array}{c}\text { Carbon content of soil after initial } \\
\text { rapid change following clearing }\end{array}$ & 50 & 24 \\
$\begin{array}{l}\text { Minimum carton content of } \\
\text { soil in cultivated system }\end{array}$ & 42 & 20 \\
\hline
\end{tabular}

D - 30 


\section{INTERNAL DISTRIBUTION}

1. D. Alvic

2. J. Barkenbus

3. L. D. Bates

4. B. A. Bervin

5. T. A. Boden

6. J. B. Cannon

7. R. B. Cook

8. J. H. Cushman

9. R. M. Cushman

10. V. H. Dale

11. R. C. Daniels

12. M. P. Farrell

13. D. E. Fowler

14. R. L. Graham

15. S. G. Hildebrand

16. S. B. Jones

17. G. R. Jacobs

18. P. Kanciruk

19. J. M. Loar

20. L. J. Morris

21. W. M. Post

22. D. E. Reichle

23. F. E. Sharples

24. D. E. Shepherd

25. S. H. Stow

26-225. CDIAC

226. Central Library

227-228. ESD Library

229-230. Laboratory Records

231. Laboratory Records-RC

232. ORNL Patent Section

233. ORNL Public Relations

234. ORNL Y-12 Tech. Library

\section{EXTERNAL DISTRIBUTION}

235. S. Alexander, Geosciences Department, Pennsylvania State University, University Park, PA 16802

236. V. Alexander, School of Fisheries and Ocean Sciences, University of Alaska, Fairbanks, AK 99775 
237. J. H. Allen, National Oceanic and Atmospheric Administration, National Geophysical Data Center, Code E/GC2,325 Broadway, Boulder, CO 80303

238. Dr. Jeffrey Amthor, Lawrence Livermore National Laboratory, Global Climate Research Division, L-256, P.O. Box 808, Livermore CA 94550-9900

239. A. Andersen, U.S. Department of Energy, Code EI-62, 1000 Independence Ave. SW, Washington, D.C. 20585

240. P. Andre, U.S. Department of Agriculture, National Agricultural Library, 10301 Baltimore Blvd., Beltsville, MD 20705

241. D. C. Bader, Battelle Pacific Northwest Laboratory, 901 D Street SW, Suite 900, Washington, D.C. 20024-2115

242. R. C. Barry, University of Colorado, World Data Center A, Glaciology, CIRES, Campus Box 449, Boulder, CO 80309-0449

243. D. Barth, Director, Harry Reid Center for Environmental Studies, 4505 South Maryland Parkway, University of Nevada, Las Vegas, NV 89154

244. G. S. Barton, GCRIO, 1747 Pennsylvania Ave. NW, Suite 200, Washington, D.C. 20006

245. M. Baumgardner, Department of Agronomy, Purdue University, 1220 Potter Drive, West Lafayette, IN 47907

246. D. Bergamaschi, OES-OA/MST, Room 5081, Department of State, Washington, D.C. 20520

247. B. Bernstein, EcoAnalysis, Inc., Arcade Plaza, Suite A, 221 East Matilija, Ojai, CA 93023-0279

248. Bert Bolin, Department of Meteorology, University of Stockholm, Arrhenius Laboratory, S106 91, Stockholm, SWEDEN

249. G. Brasseur, National Center for Atmospheric Research, P.O. Box 3000, Boulder, CO 80307-3000

250. F. Bretherton, Chair, Space Science and Engineering Center, University of Wisconsin, 1225 West Dayton Street, Madison, WI 53706

251. D. A. Bruns, Chair, Department of Earth and Environmental Sciences, Wilkes University, Wilkes-Barre, PA 18766

252. Dr. Sandra Brown, U.S. EPA, Environmental Research Laboratory, 200 SW 35th St., Corvallis, OR 97333

253. D. Butler, NASA Headquarters, Mail Code SED, Washington, DC 20546

254. R. Calender, Oceanographer of the Navy, U.S. Naval Observatory, 34th St. and Massachusetts Ave. NW, Washington, D.C. 20392-5101

255. M. S. Carter, WDC-A for Rotation of the Earth, Time Service Department, U.S. Naval Observatory, Washington, DC 20392-5100

256. M. A. Chinnery, National Oceanic and Atmospheric Administration, National Geophysical Data Center, Code E/GC2, 325 Broadway, Boulder, CO 80303

257. C. Christensen, Department of Interior, Office of Information Resources Management, 1849 C St. NW, MS-5321, Washington, D.C. 20240

258. E. Christian, U.S. Geological Survey, Information Systems Division, Reston, VA 22092

259. D. Collins, Jet Propulsion Laboratory, 4800 Oak Grove Drive, Pasadena, CA 91109 
260. P. Cornillon, Graduate School of Oceanography, Narragansett Bay Campus, University of Rhode Island, Narragansett, RI 02882

261. P. A. Crowley, Environmental Sciences Division, Office of Health and Environmental Research, ER-74, U.S. Department of Energy, Washington, D.C. 20585

262. H. Croze, Global Environment Monitoring Systems, UNEP, P. O. Box 30552 , Nairobi, KENYA

263. R. C. Dahlman, Environmental Sciences Division, Office of Health and Environmental Research, ER-74, U.S. Department of Energy, Washington, D.C. 20585

264. K. Davidson, Deputy Director, National Climatic Data Center, Federal Building, Asheville, NC 28801

265. L. DeMouy, U.S. Department of Energy, Code EI-623, 1000 Independence Ave. SW, Washington, D.C. 20585

266. S. Digby, Jet Propulsion Laboratory, 4800 Oak Grove Drive, Pasadena, CA 91109

267. Dr. Robert K. Dixon, U.S. Country Studies Program, 1000 Independence Avenue, SW, PO-63, Washington, DC 20585

268. B. C. Douglas, National Oceanographic Data Center, NOAA, Room 406, Universal Building South, 1825 Connecticut Ave. NW, Washington, DC 20235

269. W. Draeger, EROS Data Center, U.S. Geological Survey, Sioux Falls, SD 57198

270. Jae Edmonds, Batelle Memorial Institute, Pacific Northwest Laboratories, 901 D Street, SW, Suit 900, Washington, DC 20024

271. J. W. Elwood, Environmental Sciences Division, Office of Health and Environmental Research, ER-74, U.S. Department of Energy, Washington, D.C. 20585

272. W. R. Emanuel, Environmental Sciences Department, University of Virginia, Clark Hall, Charlottesville, VA 22903

273. Energy Library (HR-832.1/GTN), U.S. Department of Energy, Office of Administration and Management, G-034 Germantown, Washington, D.C. 20585

274. Energy Library (HR-832.2/WAS), U.S. Department of Energy, Office of Administration and Management, GA-138 Forrestal Building, Washington, D.C. 20585

275. L. Enomoto, NOAA/NESDIS, FB-4, Room 0110, Washington, D.C. 202330001

276. G. Evans, U.S. Department of Agriculture, Global Change Program Office, 1621 N. Kent Street, Room 60LL, Arlington, VA 22209

277. Dr. Gerd Esser, MASA, Leader Biosphere Dynamics Project, A-2361 Laxenburg, AUSTRIA

278. R. N. Farvolden, Professor, Department of Earth Sciences, University of Waterloo, Waterloo, Ontario N2L 3G1 CANADA 
279. J. Fein, National Science Foundation, Atmospheric Science Division, $1800 \mathrm{G}$ St. NW, Washington, D.C. 20550

280. W. Ferrell, U.S. Department of Energy, 1000 Independence Ave. SW, Washington, D.C. 20585

281. J. Filson, National Earthquake Information Center, U.S. Geological Survey, Denver Federal Center, P.O. Box 20546, Denver, CO 80225

282. E. P. Flint, Department of History, 226 Carr Bldg., Duke University, Durham, NC 27707

283. J. F. Franklin, Bloedel Professor of Ecosystem Analysis, College of Forest Resources, University of Washington, Anderson Hall (AR-10), Seattle, WA 98195

284. D. W. Freckman, Director, College of Natural Resources, 101 Natural

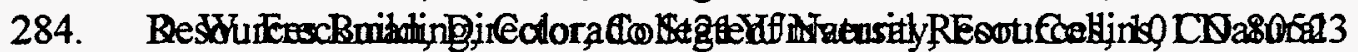

285. I. Fung, School of Earth and Ocean Sciences, University of Victoria, P.O. Box 1700 , Victoria, BC V8W 2Y2, CANADA

286. A. Ghovanlou, Technical Director, Space Systems Division, Mitre Corporation, 7525 Colshire Drive, MS Z650, McLean, VA 22102

287. R. M. Gifford, Division of Plant Industry, CSIRO, GPO Box 1600, Canberra, ACT 2601, AUSTRALIA

288. S. N. Goldstein, National Science Foundation, 1800 G St. NW, Room 416, Washington, D.C. 20550

289. Dr. Jan Goudriaan, Department of Theoretical Production Ecology, Wageningen Agricultural University, P.O. Box 430, Wageningen, THE NETHERLANDS

290. S. Graves, NASA, Code SED, 600 Independence Ave. SW, Washington, D.C. 20546

291. J. L. Green, National Space Science Data Center, NASA Goddard Space Flight Center, Code 6302, Greenbelt, MD 20771

292-296 J. L. Hackler, The Woods Hole Research Center, P.O. Box 296, 13 Church Street, Woods Hole, MA 02543

297. K. Hadeen, NOAA National Climatic Data Center, Federal Building, Asheville, NC 28801

298. C. A. S. Hall, State University of New York, College of Environmental Sciences and Forestry, 301 Illick Hall, 1 Forestry Drive, Syracuse, NY 13210

299. D. O. Hall, Division of Life Sciences, King's College London, University of London, Campden Hill Road, London W8 7AH, UK

300. Jennifer Harden, U.S. Geological Survey, 345 Middlefield Road, MS-975, Menlo Park, CA 94025

301. Dr. L.D. Harvey, Department of Geography, University of Toronto, $100 \mathrm{St}$. George Street, Toronto, Ontario M5S 1A1, CANADA

302. R. Hayes, Oceanographer of the Navy, U.S. Naval Observatory, 34th St. and Massachusetts Ave. NW, Washington, D.C. 20392-5101

303. G. M. Hornberger, Professor, Department of Environmental Sciences, University of Virginia, Charlottesville, VA 22903 
304. J. C. Houghton, Environmental Sciences Division, Office of Health and Environmental Research, ER-74, U.S. Department of Energy, Washington, D.C. 20585

305-309. R. A. Houghton, The Woods Hole Research Center, P.O. Box 296, 13 Church Street, Woods Hole, MA 02543

310. M. K. Hughes, Laboratory Tree-Ring Research, University of Arizona, 1105 W. Stadium, Tucson, AZ 85721

311. W. J. Hughes, Center for Space Physics, Boston University, 725 Commonwealth Avenue, Boston, MA 02215

312. G. Hunolt, NASA, Code SED, 600 Independence Ave. SW, Washington, D.C. 20546

313. Dr. L. Iverson, Northeastern Forest Experiment Station, USDA Forest Service, 359 Main Road, Delaware, OH 43105

314. K. C. Jezek, Byrd Polar Research Center, The Ohio State University, 108 Scott Hall, 1090 Carmack Road, Columbus, OH 43210-1002

315. D.M. Kammen, Woodrow Wilson School of Public and International Affairs, Princeton University, Princeton, NJ 08544

316. C. D. Keeling, Geological Research Division, Scripps Institution of Oceanography, University of California-San Diego, Mail Code 0220, La Jolla, CA 92093-0220

317. R. Keeling, Marine Research Division, Scripps Institution of Oceanography, University of California-San Diego, Mail Code 0236, La Jolla, CA 920930236

318. J. H. King, WDC-A for Rockets and Satellites, National Space Science Data Center, Code 930.2, NASA Goddard Space Flight Center, Greenbelt, MD 20771

319. Dr. Niraj Kumar, Department of International and Public Affairs, Columbia University, 420 West 118th Street, New York, NY 10027

320. W. A. Kurz, ESSA Technologies Ltd., 1765 West 8th Avenue, Suite 300, Vancouver, BC V6J 5C6, CANADA

321. D. T. Lauer, EROS Data Center, U.S. Geological Survey, Sioux Falls, SD 57198

322. S. Levitus, WDC-A for Oceanography, NOAA/NESDIS, E/OC23, Universal Building, Room 409, 1825 Connecticut Ave. NW, Washington, DC 20235

323. A. M. Linn, Program Officer, BESR, National Academy of Sciences, Harris Building 372, 2001 Wisconsin Ave. NW, Washington, DC 20007

324. Dr. John Lloyd, Research School of Biological Sciences, Australian National University, GPO Box 475, Canberra, ACT 2601, AUSTRALIA

325. M. S. Loughridge, National Oceanic and Atmospheric Administration, National Geophysical Data Center, Code E/GC3, 325 Broadway, Boulder, CO 80303

326. G. H. Ludwig, HC 33, Box 641, Winchester, VA 22601

327. P. Lunn, Environmental Sciences Division, Office of Health and Environmental Research, ER-74, U.S. Department of Energy, Washington, D.C. 20585 
328. T. H. Mace, U.S. Environmental Protection Agency, Room 1123 West Tower, 401 M St. SW, Washington, D.C. 20460

329. Elaine Matthews, NASA/GISS, 2880 Broadway, New York, NY 10025

330. L. McGoldrick, SMSystems and Research Corp., 300 D St. SW, Suite 840, Washington, D.C. 20024

331. M. K. McNutt, Department of Earth, Atmosphere, and Planetary Sciences, Building 54, Room 82226, Massachusetts Institute of Technology, 54 Ames Street, Cambridge, MA 02139

332. C. Miller, NOAA/NESDIS, 1825 Connecticut Ave. NW, Suite 506, Washington, DC 20235

333. Berrien Moore III, Institute for the Study of Earth, Oceans, and Space, University of New Hampshire, Morse Hall, Room 305, Durham, NH 03824

334. R. E. Munn, University of Toronto, Institute for Environmental Studies, Toronto, Ontario M5S 184, CANADA

335. B. Niemann, U.S. Environmental Protection Agency, PM-223X, 401 M St. SW, Washington, D.C. 20460

336. S. Nishioka, Director, Center for Global Environmental Research, National Institute for Environmental Studies, 16-2 Onogawa, Tsukuba, Ibaraki 305, JAPAN

337. S. Okimasa, Head, WMO World Data Center for Greenhouse Gases, 1-3-4 Otemachi, Chiyoda-ku, Tokyo 100, JAPAN

338. J. S. Olson, Global Patterns Company, Box 361 A Rt. 2, Eblen Cave Road, Lenoir City, TN 37771-9424

339. R. H. Olsen, Vice President for Research, University of Michigan, Medical Science Building II, \#5605, 1301 East Catherine Street, Ann Arbor, MI 48109-0610

340. J. T. Overpeck, National Oceanic and Atmospheric Administration, National Geophysical Data Center, 325 Broadway E/GC, Boulder, CO 80303

341. B. Parra, Environmental Sciences Division, Office of Health and Environmental Research, ER-74, U.S. Department of Energy, Washington, D.C. 20585

342. W. Parton, Natural Resource Ecology Laboratory, Colorado State University, Fort Collins, CO 80523

343. A. Patrinos, Director, Environmental Sciences Division, Office of Health and Environmental Research, ER-74, U.S. Department of Energy, Washington, D.C. 20585

344. W. Person, National Earthquake Information Center, U.S. Geological Survey, Box 25046, Mail Stop 967, Denver Federal Center, Denver, CO 80225-0046

345. L. Pettinger, National Mapping Division, USGS/DOI, 590 National Center, Reston, VA 22092

346. T. A. Potemra, Applied Physics Laboratory, The Johns Hopkins University, Johns Hopkins Road, Laurel, MD 20723-6099

347. R. Rand, USDA/NAL/ISD/DAB, 10301 Baltimore Blvd., Beltsville, MD 20705-2351 
348. I. Rasool, Lab de Meteorologie, Dynamique, Du C.N.R.S., Ecole Normale Superieure, 24 Rue Lhomond, 75231 Paris, Cedex 05m FRANCE

349. J. F. Richards, Department of History, 226 Carr Bldg., Duke University, Durham, NC 27707

350. M. R. Riches, Environmental Sciences Division, Office of Health and Environmental Research, ER-74, U.S. Department of Energy, Washington, D.C. 20585

351. M. Rodon-Naveira, EPAVORD, 401 M Street SW, Washington, D.C. 20460

352. E. Russek-Cohen, Department of Animal Sciences, University of Maryland, College Park, MD 20742

353. Dr. Jayant Sathaye, Lawrence Berkeley Laboratory, University of California, Berkeley, CA 94720

354. G. S. Sayler, Professor, 10515 Research Drive, Suite 100, The University of Tennessee, Knoxville, TN 37932-2567

355. D. S. Schimel, Climate Systems Modeling Program, University Corporation for Atmospheric Research, P.O. Box 3000, Boulder, CO 80307-3000

356. W. H. Schlesinger, Department of Botany and Geology, Duke University, P.O. Box 90338, Durham, NC 27708-0340

357. H. H. Shugart, Department of Environmental Sciences, Clark Hall, University of Virginia, Charlottesville, VA 22903

358. A. L. Shumbera, National Oceanic and Atmospheric Administration, WDC-A for Meteorology, National Climatic Data Center, Federal Building, MC E/CC, Asheville, NC 28801

359. J. Simpson, Earth Sciences Director, Severe Storms, Code 912, Building 22, Room 330, NASA/Goddard Space Flight Center, Greenbelt, MD 20771

360. D. L. Skole, Complex Systems Research Center, University of New Hampshire, Durham, NH 03824-3535

361. S. Sorooshian, Department of Hydrology and Water Resources, University of Arizona, Tucson, AZ 85721

362. Dr. John Taylor, Centre for Resource and Environmental Studies, Australian National University, GPO Box 4, Canberra, ACT 2601, AUSTRALIA

363. R. E. Thompson, Department of Agriculture, National Agricultural Library, 10301 Baltimore Blvd./5th Floor, Beltsville, MD 20705

364. J. R. G. Townshend, Department of Geography, 1113 Lefrak Hall, University of Maryland, College Park, MD 20742

365. B. J. Turner, Marsh Institute, Clark University, 950 Main Street, Worcester, MA 01610-1477

366. Dr. Thompson Webb III, Department of Geological Sciences, Brown University, Providence, RI 02912-1846

367. G. B. Wiersma, Dean, College of Forest Resources, Maine Agricultural Experiment Station, 202 Nutting Hall, University of Maine, Orono, ME 04469

368. T.M.L. Wigley, Office for Interdisciplinary Earth Studies, University Corporation for Atmospheric Research, P.O. Box 3000, Boulder, CO 80307 3000 
369. R. Williams, U.S. Department of Agriculture, OIRM - Room 414-W, Washington, D.C. 20250

370. G. Withee, NOAANODC, Room 506, 1825 Connecticut Ave. NW, Washington, D.C. 20235

371. F. J. Wobber, Environmental Sciences Division, Office of Health and Environmental Research, ER-74, U.S. Department of Energy, Washington, D.C. 20585

372. Office of Assistant Manager for Energy Research and Development, U.S. Department of Energy Oak Ridge Operations, P.O. Box 2001, Oak Ridge, TN $37831-8600$

373-377. Office of Scientific and Technical Information, P.O. Box 62, Oak Ridge, TN 37831

378. John Klink, Department of Geography, Miami University, Oxford, OH 45056

379. Sean Hartnett, Department of Geography, University of Wisconsin-Eau Claire, Eau Claire, WI 54701 